\title{
27. ORIGINS, TIMING, AND IMPLICATIONS OF MIOCENE TO PLEISTOCENE TURBIDITES, DEBRIS FLOWS, AND SLUMP DEPOSITS OF THE OUEENSLAND TROUGH, NORTHEASTERN AUSTRALIA (SITE 823) ${ }^{1}$
}

\author{
K.F. Watts, ${ }^{2}$ L.L. Varga, ${ }^{3}$ and D.A. Feary ${ }^{4}$
}

\begin{abstract}
More than 2000 turbidite, debris-flow, and slump deposits recovered at Site 823 record the history of the Queensland Trough since the middle Miocene and provide new insights about turbidites, debris flow, and slump deposits (herein termed gravity deposits). Changes in the composition and nature of gravity deposits through time can be related to tectonic movements, fluctuations in eustatic sea level, and sedimentological factors. The Queensland Trough is a long, relatively narrow, structural depression that formed as a result of Cretaceous to Tertiary rifting of the northeastern Australia continental margin. Thus, tectonics established the geometry of this marginal basin, and its steep slopes set the stage for repeated slope failures. Seismic data indicate that renewed faulting, subsidence, and associated tectonic tilting occurred during the early late Miocene (continuing into the early Pliocene), resulting in unstable slopes that were prone to slope failures and to generation of gravity deposits. Tectonic subsidence, together with a second-order eustatic highstand, resulted in platform drowning during the late Miocene.

The composition of turbidites reflects their origin and provides insights about the nature of sedimentation on adjacent shelf areas. During relative highstands and times of platform drowning, planktonic foraminifers were reworked from slopes and/or drowned shelves and were redeposited in turbidites. During relative lowstands, quartz and other terrigenous sediment was shed into the basin. Quartzose turbidites and clay-rich hemipelagic muds also can record increased supply of terrigenous sediment from mainland Australia. Limestone fragments were eroded from carbonate platforms until the drowned platforms were buried under hemipelagic sediments following the late Miocene drowning event. Bioclastic grains and neritic foraminifers were reworked from neritic shelves during relative lowstands. During the late Pliocene $(2.6 \mathrm{Ma})$, the increased abundance of bioclasts and quartz in turbidites signaled the shallowing and rejuvenation of the northeastern Australia continental shelf. However, a one-for-one relationship cannot be recognized between eustatic sea-level fluctuations and any single sedimentologic parameter. Perhaps, tectonism and sedimentological factors along the Queensland Trough played an equally important role in generating gravity deposits.

Turbidites and other gravity deposits (such as those at Site 823) do not necessarily represent submarine fan deposits, particularly if they are composed of hemipelagic sediments reworked from drowned platforms and slopes. When shelves are drowned and terrigenous sediment is not directly supplied by nearby rivers/point sources, muddy terrigenous sediments blanket the entire slope and basin, rather than forming localized fans. Slope failures affect the entire slope, rather than localized submarine canyons. Slopes may become destabilized as a result of tectonic activity, inherent sediment weaknesses, and/or during relative sea-level lowstands. For this reason, sediment deposits in this setting reflect tectonic and eustatic events that caused slope instabilities, rather than migration of different submarine fan facies.
\end{abstract}

\section{INTRODUCTION}

Site 823 is located near the axis of the Queensland Trough, a structural depression between the northeastern Australia shelf and the Queensland Plateau (Figs. 1 and 2). Although this basinal site was chosen to obtain a paleoceanographic record from hemipelagic muds, more than 2000 turbidites, debris flows, and slump deposits were encountered in $1011 \mathrm{~m}$ of middle Miocene to Holocene sediments cored at Holes $823 \mathrm{~A}$ through $823 \mathrm{C}$ (Figs. 3 and 4). In this study, such submarine gravity mass flow deposits are termed "gravity deposits" for brevity. The Queensland Trough apparently served as the final resting place for a variety of gravity deposits that were transported downslope from both the northeastern Australia continental shelf margin and the Queensland Plateau. Here, we consider variations in the nature, composition, distribution, age, frequency, thickness, and grain size of these gravity deposits. Our analyses of turbidite compositions provide insights into the history of the northeastern Australia margin over the last 10.4 m.y.

\footnotetext{
'McKenzie, J.A., Davies, P.J., Palmer-Julson, A., et al., 1993. Proc. ODP, Sci. Results. 133: College Station, TX (Ocean Drilling Program).

${ }^{2}$ Department of Geology and Geophysics, and the Geophysical Institute, University of Alaska-Fairbanks, Fairbanks, AK 99775 , U.S.A

${ }_{3}^{3}$ Geophysical Institute, University of Alaska-Fairbanks, Fairbanks, AK 99775, U.S.A.

${ }^{4}$ Australian Geological Survey Organisation (formerly Bureau of Mineral Resources), Canberra, Australia.
}

Of more general interest, we interpret the influence of tectonics, sedimentation, and sea-level fluctuations on the composition and on the nature of a variety of gravity deposits. Turbidites are generated by the subaqueous downslope movement of relatively dense mixtures of sediment and water as turbidity currents. They can be initiated by slope failures or by sediment moving off the shelf during storms. Slope failures can be initiated by inherent instabilities of thick accumulations of sediments along continental slopes, or they can be triggered by large storm waves, seismic shocks, or the movement of other sediment gravity flows (Cook, 1979; Einsele, 1991). With the lowering of sea level, terrigenous sediments may be transported across emergent shelves, spill over the shelf edge, and move directly downslope as turbidites (Vail et al., 1977; Shanmugam and Moiola, 1982; Posamentier and Vail, 1988). The shelf margin and slope may also be destabilized by storm waves during eustatic lowstands. Thus, turbidites and lowstand fans are thought to indicate periods of relatively low sea level (Vail et al., 1977; Shanmugam and Moiola, 1982; Posamentier and Vail, 1988). However, isolated carbonate platforms, such as the Bahamas, produce more sediment during highstands when banks are flooded, with a concomitant increase in calciturbidites (Mullins, 1983; Droxler and Schlager, 1985; Boardman et al., 1986). Other carbonate systems having adjacent sources of siliciclastic sediment (such as the Permian Basin) may have generated sediment gravity flows during lowstands (Thiede, 1981; Shanmugam and Moiola, 1984; Schlanger and Premoli Silva, 1986; Sarg, 1988; Dolan, 1989; Yose and Heller, 1989). The Queensland Trough is more complicated and contains turbidites derived from a variety of sources, 


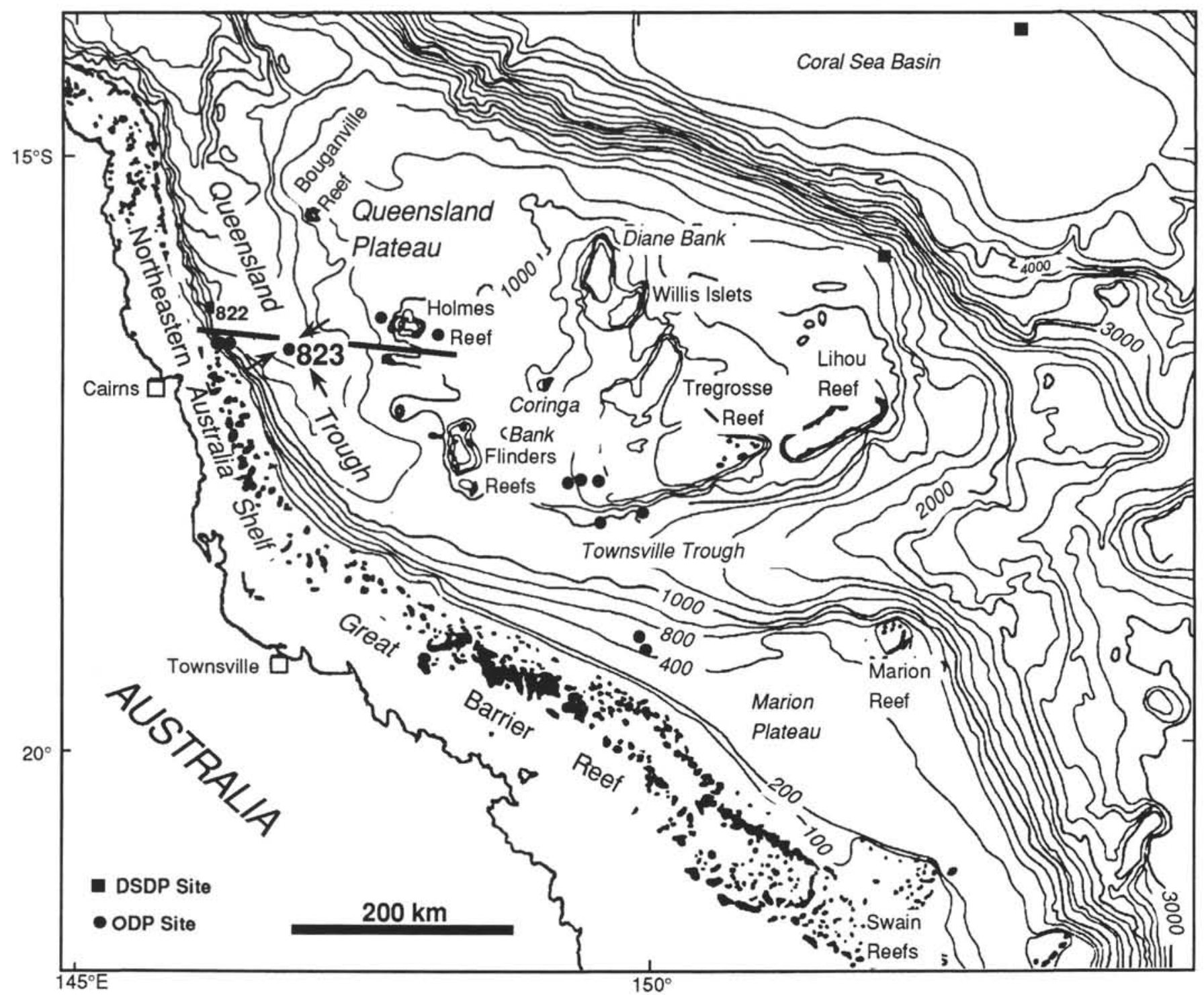

Figure 1. Map showing location of Site 823 in the Queensland Trough. Arrows indicate possible directions of transport of sediment from the northeastern Australia shelf, the Queensland Plateau, and down the axis of the Queensland Trough (modified after Shipboard Scientific Party, 1991). Line shows approximate location of the schematic profile shown in Figure 2.

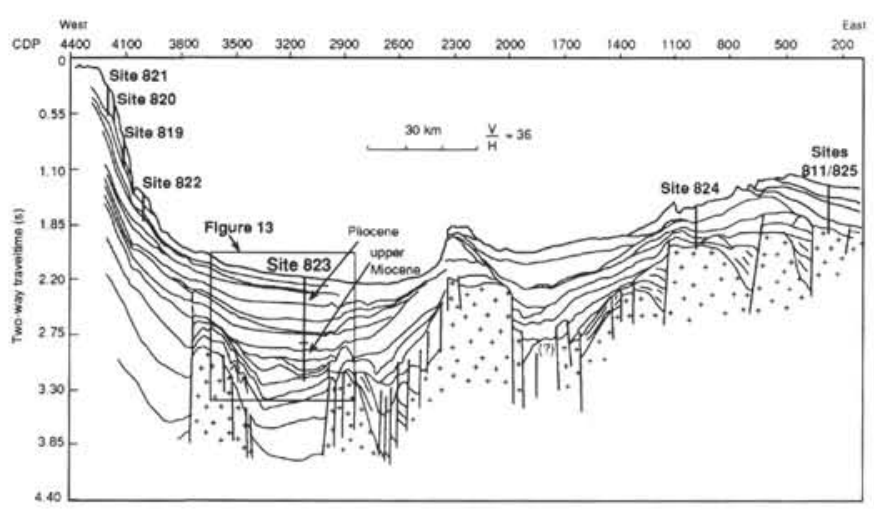

Figure 2. Schematic profile across the Queensland Trough showing location of Site 823 (modified after Feary et al., 1990). Box shows the location of the seismic line in Figure 13. including terrigenous sediments from the Australian mainland and local basement highs, and carbonate sediments from both platform and pelagic sources. Platform drowning has been particularly important in determining the composition and nature of gravity deposits (see Schlager, 1980, 1981). In this study, we analyze the gravity deposits of the Queensland Trough (Site 823) and consider their relationship to tectonics, sedimentological controls, and eustatic sealevel fluctuations (Haq et al., 1988; Wornardt and Vail, 1991).

\section{METHODS}

The excellent core recovery ( $92 \%$ recovery) and relatively continuous record of sedimentation at Site 823 provide an excellent opportunity to determine the origin and significance of a variety of gravity deposits. Site 823 is located near the axis of the Queensland Trough in water depths of $1650 \mathrm{~m}$ (Shipboard Scientific Party, 1991). In our study, the sedimentology of all the gravity deposits recovered in the 1011-m cored interval was examined in cores and thin sections. Three-dimensional seismic data provide information about deposi- 


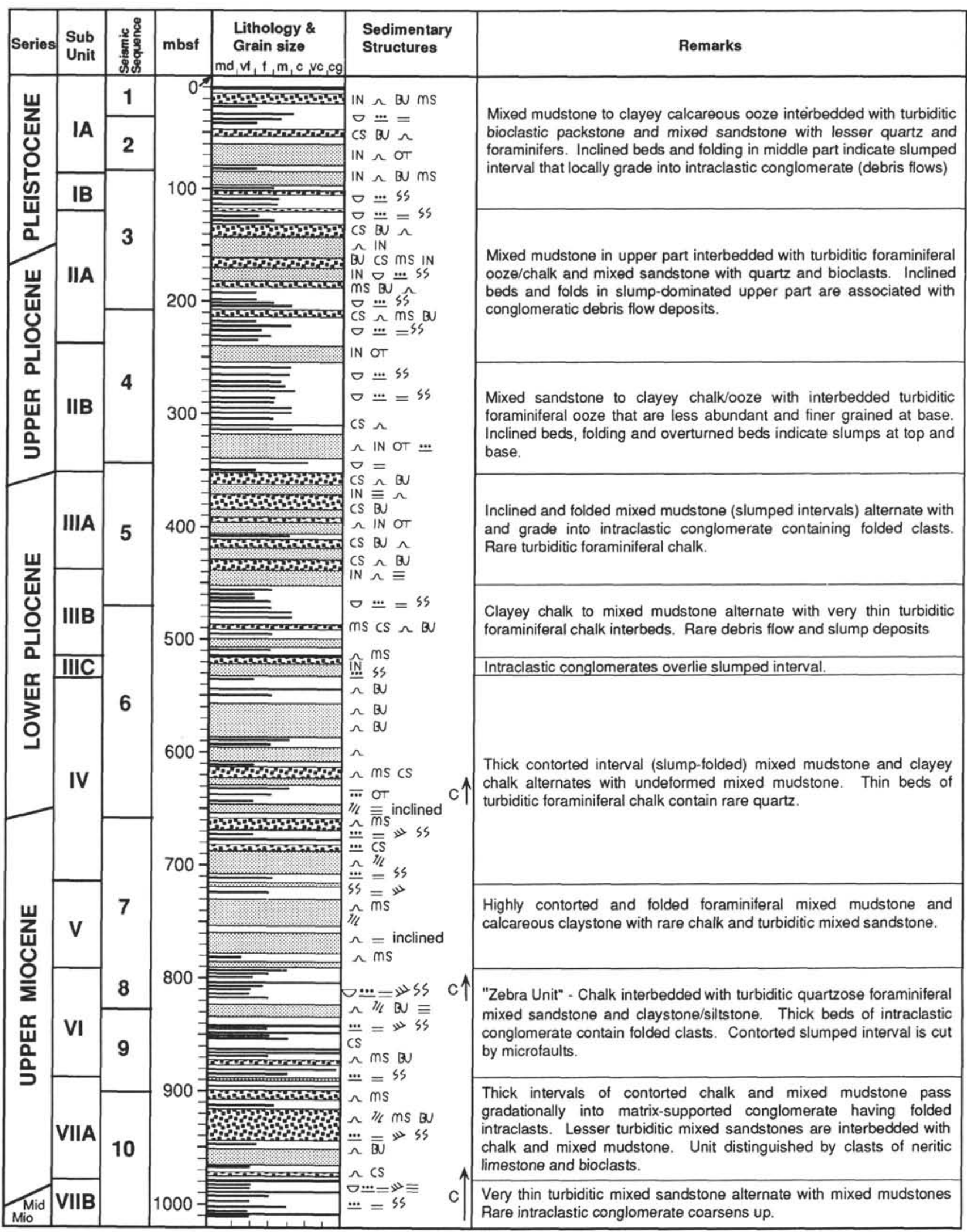

Figure 3. Generalized stratigraphic column summarizing variations in the types of gravity deposits at Site 823 . See Figure 4 for key to symbols. 
tional setting and thickness variations in seismic units that are correlated with the different lithostratigraphic units (Fig. 3). High-resolution age control was provided from shipboard biostratigraphic work (Shipboard Scientific Party, 1991) and post-cruise revisions (Wei, pers. comm., 1992; Kroon, pers. comm., 1992).

\section{Core Descriptions}

All the cores from Site 823 (except the upper part of Hole 823B that coincides with Hole $823 \mathrm{~A}$ ) were described by Keith Watts at the Gulf Coast repository at Texas A\&M University (TAMU). The inter$\mathrm{val}$, bed thickness, grain sizes, sedimentary structures, and depositional mechanism were recorded for each gravity deposit $(\geq 1 \mathrm{~cm}$ in thickness). These data, calculated depths (mbsf), ages (Ma), and sedimentation rates $(\mathrm{m} / \mathrm{m}$.y.) for the upper $500 \mathrm{~m}$ of core were entered into a computerized database. Data from the lower $500 \mathrm{~m}$ of core have not been computerized (the data entry form was developed after this was described).

\section{Petrographic Analyses}

Samples of turbidites and a few representative samples of debrisflow, slump, and hemipelagic deposits were collected on board the JOIDES Resolution and at the TAMU Gulf Coast Repository. Thin sections prepared from each sample were analyzed with petrographic microscope to determine compositional variations. A total of 390 samples were analyzed in detail, and cursory examinations were done for another $\sim 100$ samples in units dominated by pelagic foraminifers (most petrographic analyses were performed by Lisa Varga). The relative abundance of different components (e.g., foraminifers, quartz, bioclasts, etc.; see Fig. 5) was estimated visually (abundant $=>30 \%$, common $=15 \%-30 \%$, few $=3 \%-15 \%$, and rare $=<3 \%$ ). The results of thin-section analyses were recorded and entered into a computerized database (Fig. 5, Appendix B). The position of samples and results of petrographic analyses are shown in stratigraphic columns that illustrate changes in turbidite compositions (bioclasts, quartz, and foraminifers) at Site 823 (see below). Plates 1 and 2 illustrate typical compositions and textures of different turbidites at Site 823 .

\section{Sedimentology and Terminology}

Because the hemipelagic, turbidite, debris-flow, and slump deposits of Site 823 each have considerable compositional variations, a simple descriptive terminology cannot be used to compare and contrast these different deposits. Although somewhat interpretive, we describe these deposits as hemipelagic muds, turbidites, and debrisflow and slump deposits to facilitate discussions. Table 1 outlines the characteristics distinguishing each type of deposit. Plates 3 and 4 illustrate the interrelationships between different types of gravity deposits. Descriptions of each unit provide specific information about lithology, composition, and the nature of each deposit that further substantiate these initial sedimentologic interpretations. This approach allows us to focus on the interrelationship between sediment composition and depositional mechanisms and their response to tectonics, sediment supply, and sea-level fluctuations (see below).

Sediment gravity flows (e.g. turbidites and debris flows) and mass movements (together simply termed "gravity deposits") are shortterm event deposits that result from slope failures and the subaqueous downslope movement of sediment (Einsele, 1991; Eberli, 1991). Turbidity currents are unconsolidated viscous slurries of sediment and water that moved down subaqueous slopes as density currents to be deposited as turbidites (Kuenen and Migliorini, 1950; Bouma, 1962). Debris-flow deposits generally consist of disintegrated masses of poorly consolidated sediments (intraclasts) having a plastically deformed muddy matrix (Einsele, 1991). Their close association with slump deposits and abundance of folded intraclasts indicate that many debris flows initiated as slumps and slides that disintegrated as they were transported downslope (Pls. 3 and 4; see Cook and Mullins, 1983; Stanley, 1985). Coherent slump and slide blocks moved downslope as mass movements when downslope shear stress exceeded the shear strength of sediments (Einsele, 1991). Such gravity deposits clearly reflect close proximity to a slope, although turbidites can be transported great distances (Eberli, 1991). Slope failures result from gravitational instabilities related to the declivity of the slope (steepness), the nature/strength of slope sediment, and other factors such as seismic shocks and storm waves that decrease the stability of subaqueous slopes (Cook and Mullins, 1983; Einsele, 1991).

\section{Seismic Data}

David Feary processed and interpreted the site-survey seismic data using a LANDMARK interactive workstation and produced horizon depth contour and isopach maps for each seismic sequence (see "Methods" section in Feary et al., this volume). These were depth converted using average velocities calculated from drill-hole intersections, after synthetic seismograms were used to correlate seismic and drill-hole data (see Feary et al., this volume). Based on these analyses, it is apparent that the seafloor in most of the sequences sloped gently to the northeast, similar to the present-day slope of the seafloor (Fig. 2 and see below). The lower sequences apparently sloped in a more easterly direction and have variable isopach trends that suggest derivation from both the east and the west. The lowest sequences (sequences 10 and 11 of Shipboard Scientific Party, 1991, pp. 749-750) slope to the west, indicating tectonic tilting (Fig. 2; see below).

\section{Age Control}

The age control provided by biostratigraphic zonation of foraminifers and nannofossils generally is good. Nearly all middle Miocene to Pleistocene biohorizons are present (Shipboard Scientific Party, 1991,pp. 703-705). Ages (based on biohorizons) are generally tightly bracketed (0.1-1.55 m.y. between different biohorizons), with ages for Pliocene and younger sediments being better constrained than those for the Miocene. In Units V to VII, a gap in age control between 767.4 and 967.4 mbsf $(5.90-8.20 \mathrm{Ma})$ is the only serious omission (Shipboard Scientific Party, 1991, pp. 703-705; Wei and Kroon, pers. comm., 1991). The age of each gravity deposit was calculated by assuming a constant sedimentation rate between adjacent biohorizons (depth of first or last occurrence) and linear age interpolation. Although assuming a constant sedimentation rate may be a valid approximation where biohorizons are closely spaced, variable sedimentation rates and the paucity of biohorizons in Units V to VII precluded precise age determination (Table 2).

The absence of major erosional features at Site 823 together with its generally uninterrupted succession of biohorizons, uniformly high sedimentation rates, and abundance of interbedded thin turbidites and hemipelagic sediments all suggest that Site 823 was an area of continuous sedimentation. However, thick debris-flow and slump deposits were deposited extremely rapidly, indicating nonlinear sedimentation rates that result in errors in age estimates. Furthermore, because several of the biohorizons occur within gravity deposits (turbidites, debris-flow and slump deposits), their ages may be inaccurate (Tables 2 and 3). This is clearly the case with Discoaster brouweri in a debris-flow deposit in Unit II (see below).

Future biostratigraphic studies of only hemipelagic sediments may improve the accuracy of age assignments by eliminating the effects of reworking. However, caution should be exercised because homogeneous muds inferred to represent bioturbated hemipelagic sediments may actually be redeposited gravity deposits that were transported by mudflows, etc. For example, as much as two-thirds of comparable muddy base-of-slope sediments in the Miocene-Pliocene of Sardinia represent gravity deposits (Stanley, 1985). If it is possible to resolve uncertainties in biostratigraphic age assignments (and utilize oxygen-isotope stratigraphy), future studies will be able to deter- 


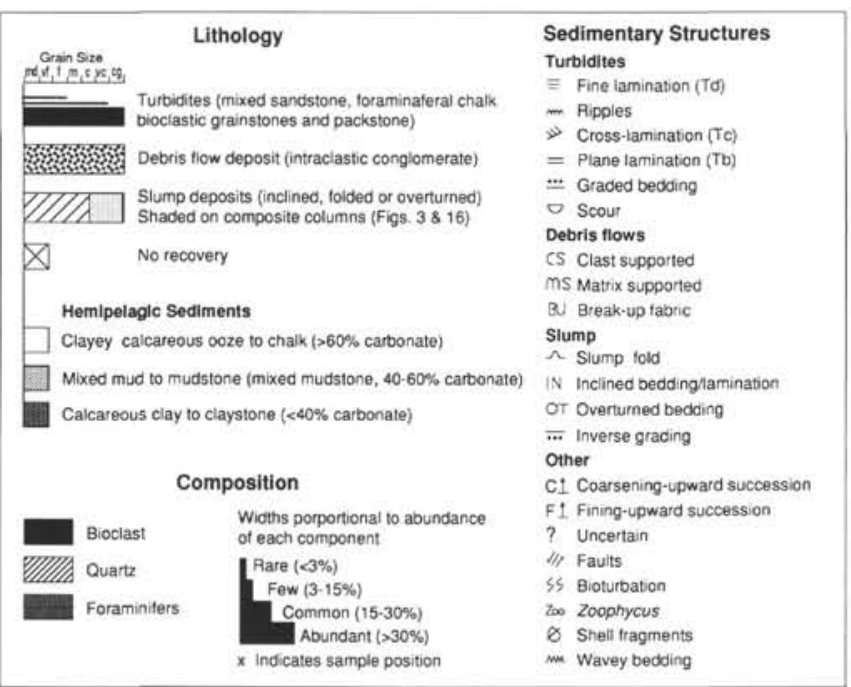

Figure 4. Explanation for symbols used in stratigraphic columns (Figs. 3, 6-11, 15 , and 16). mine more accurately the ages of gravity deposits by using sedimentation rates and cumulative thicknesses of hemipelagic sediments (and separately determining sedimentation rates of different types of gravity deposits).

\section{RESULTS}

Description and interpretation of gravity deposits of Site 823 were sizable tasks, given the large amount of variability in their composition and nature. Simplified stratigraphic columns illustrate the succession of deposits comprising each lithostratigraphic unit at Site 823 and accompany the following descriptions. More detailed data for the thickness, grain size, and composition of turbidites in the succession are provided in Appendixes A and B. Lithostratigraphic units were defined based on variations in their gravity deposits (Fig. 3; Shipboard Scientific Party, 1991). Each unit description sequentially considers the organization and nature of turbidites and debris-flow, slump, and hemipelagic deposits, their age control, and their relationship to seismic sequences (for the lower units). Later discussions about the depositional history of the Queensland Trough (Site 823) and factors controlling the nature and significance of gravity deposits are based on these results.

\section{PETROGRAPHIC DESCRIPTION}

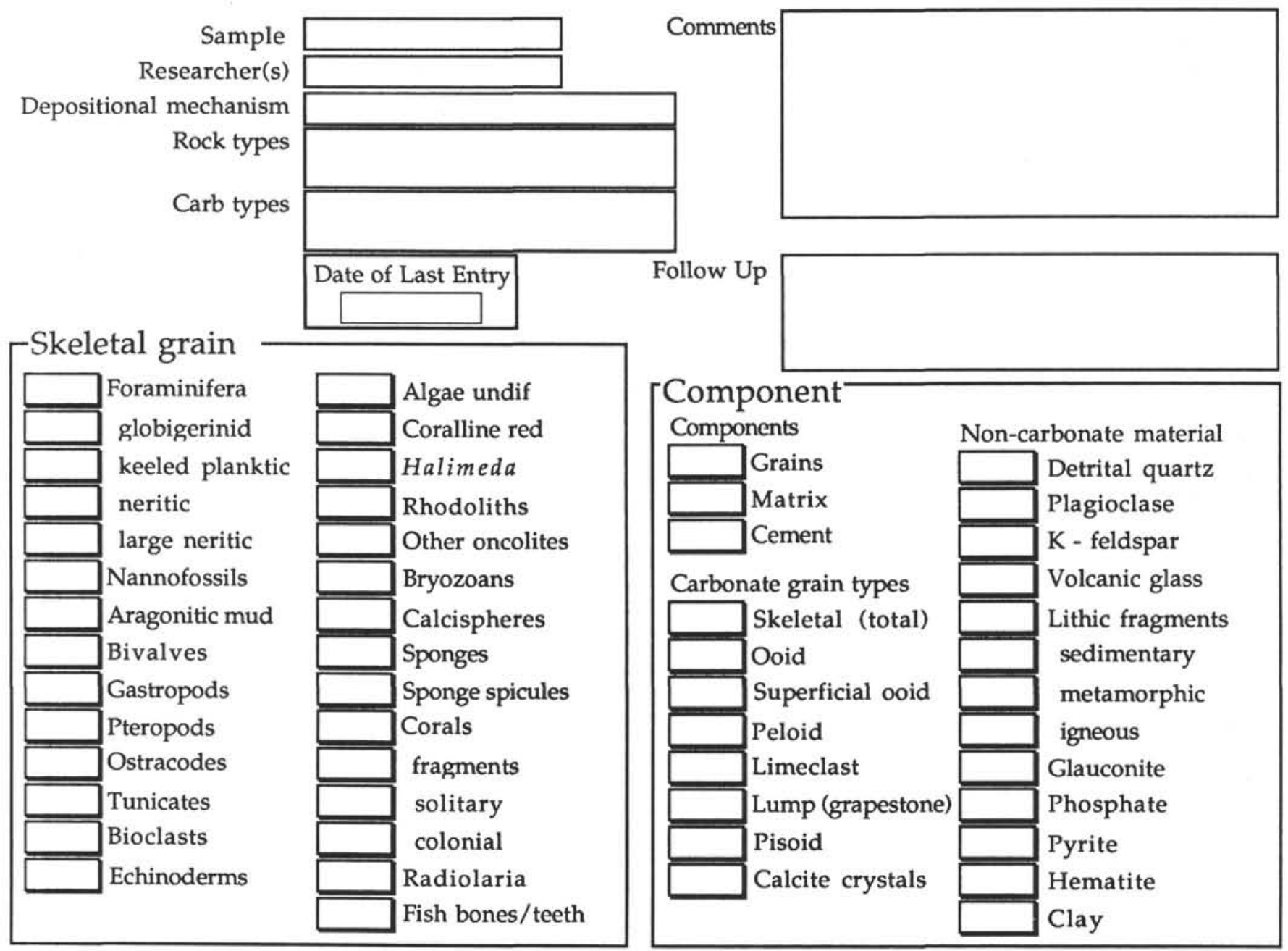

A C F R 0 - Abundant ( $>30 \%)$, Common (15-30\%), Few (3-15\%), Rare (<3\%), 0 (none), E (Exact number from point count)

Figure 5. Petrographic data recorded and entered into computerized database. 
Table 1. Distinguishing characteristics of hemipelagic sediments, turbidites, and slump and debris flow deposits, including sedimentary structures, sediment compositions and/or lithologies along with inferred sediment sources.

\begin{tabular}{|c|c|c|c|}
\hline Depositional mechanism & Sedimentary structures & Sediment types/Lithologies & Derivation \\
\hline Hemipelagic "rain" & $\begin{array}{l}\text { Bioturbation } \\
\text { Lamination }\end{array}$ & $\begin{array}{l}\text { White clayey forminiferal nannofossil } \\
\text { (calcareous) ooze/chalk }\left(60 \% \mathrm{CaCO}_{3}\right) \\
\text { Greenish-gray mixed (marly) } \\
\text { mud/mudstone }\left(40 \%-60 \% \mathrm{CaCO}_{3}\right) \\
\text { Dark greenish-gray calcareous } \\
\text { clay/claystone }\left(<40 \% \mathrm{CaCO}_{3}\right)\end{array}$ & $\begin{array}{l}\text { Mostly pelagic ooze and/or periplatform } \\
\text { (aragonitic) ooze } \\
\text { Mixed pelagic ooze and terrigenous mud } \\
\text { Mostly terrigenous mud }\end{array}$ \\
\hline Turbidity currents & $\begin{array}{l}\text { Discrete beds of sand-sized sediment } \\
\text { (turbidites) } \\
\text { Bouma sequences } \\
\text { Te - hemipelagic mud } \\
\mathrm{Td} \text { - laminated silt } \\
\mathrm{Tc} \text { - ripple x-lamination } \\
\mathrm{Tb} \text { - plane lamination } \\
\mathrm{Ta} \text { - graded bedding } \\
\text { Erosional bases - scours } \\
\text { Bioturbated tops }\end{array}$ & $\begin{array}{l}\text { Bioclastic grainstone } \\
\text { Foraminifer ooze/chalk } \\
\text { Mixed sandstone } \\
\text { Mixtures of above }\end{array}$ & $\begin{array}{l}\text { Neritic shelves } \\
\text { Reworked pelagic foraminifers } \\
\text { Terrigenous sediment from Australian mainland } \\
\text { and/or basement horsts }\end{array}$ \\
\hline Debris flows & $\begin{array}{l}\text { Matrix-supported fabrics } \\
\text { Clast-supported fabrics } \\
\text { Clast break-up fabrics } \\
\text { Folded clasts } \\
\text { Contorted matrix and/or clasts } \\
\text { Bioturbation crosscutting clasts and/or ma- } \\
\text { trix }\end{array}$ & $\begin{array}{l}\text { Intraclastic conglomerates and rare breccias. } \\
\text { Intraclasts range from mud/claystone to } \\
\text { calcareous ooze/chalk and lesser turbidite } \\
\text { fragments. Most common matrix is mixed } \\
\text { mud/mudstone. Limestone fragments in Unit VII. }\end{array}$ & $\begin{array}{l}\text { Disintegration of slump blocks into coherent clasts } \\
\text { and incompetent matrix. Rare limestone } \\
\text { fragments were derived from carbonate platforms. }\end{array}$ \\
\hline Slumps & $\begin{array}{l}\text { Inclined lamination/bedding } \\
\text { Soft-sediment deformation ("slump" } \\
\text { folds) } \\
\text { Microfaults } \\
\text { Axial planar cleavage }\end{array}$ & $\begin{array}{l}\text { Hemipelagic mud/mudstone ranging in } \\
\text { composition from calcareous (nannofossil- } \\
\text { foraminifer) ooze/chalk to calcareous } \\
\text { mud/claystone.Incorporated turbidite beds may be } \\
\text { folded and/or overtumed }\end{array}$ & $\begin{array}{l}\text { Downslope mass movements of relatively compe- } \\
\text { tent muds as slumps or slide blocks. } \\
\text { Intemal disruption results from plastic } \\
\text { deformation of unconsolidated sediment. } \\
\text { Microfaults (from tectonic movements) and axial } \\
\text { planar cleavage result from deformation of } \\
\text { relatively brittle semi-consolidated sediments. }\end{array}$ \\
\hline
\end{tabular}

Table 2. Depths of nannofossil and foraminifer biohorizons with inferred ages and calculated sedimentation rates.

\begin{tabular}{|c|c|c|c|c|c|c|c|c|}
\hline Type & Abbreviation & Species & $\begin{array}{c}\text { Sample } \\
\text { (first; } \mathrm{cm} \text { ) }\end{array}$ & $\begin{array}{c}\text { Sample } \\
\text { (range; } \mathrm{cm} \text { ) }\end{array}$ & $\begin{array}{l}\text { Depth } \\
\text { (mbsf) }\end{array}$ & $\begin{array}{l}\text { Age } \\
\text { (Ma) }\end{array}$ & $\begin{array}{l}\text { Sed. rate } \\
(\mathrm{m} / \mathrm{m} . \mathrm{y} .)\end{array}$ & $\begin{array}{l}\text { Dep. } \\
\text { mech. }\end{array}$ \\
\hline F & G.r. & Globigerinodes ruber & $823 \mathrm{~A}-2 \mathrm{H}$ & $823 \mathrm{~A}-1 \mathrm{H}$ & 10.55 & .12 & 87.92 & $?$ \\
\hline $\mathrm{N}$ & E.h.(B) & Emiliania huxleyi & $823 \mathrm{~A}-2 \mathrm{H}-4,115$ & $823 \mathrm{~A}-2 \mathrm{H}-5,115$ & 12.20 & .28 & 10.31 & $\mathrm{H}$ \\
\hline $\mathrm{N}$ & P.I. & Pseudoemiliania lacunosa & $823 \mathrm{~A}-4 \mathrm{H}-4,115$ & $823 \mathrm{~A}-4 \mathrm{H}-6,115$ & 31.95 & .47 & 103.95 & $\mathrm{H}$ \\
\hline $\mathrm{F}$ & G.t. & Globorotalia tosaensis & $823 \mathrm{~A}-7 \mathrm{H}$ & $823 \mathrm{~A}-6 \mathrm{H}$ & 58.05 & .60 & 200.77 & ? \\
\hline $\mathrm{N}$ & small $G$. & small Gephyrocapsa Acme & $823 \mathrm{~A}-9 \mathrm{H}-5,115$ & $823 \mathrm{~A}-9 \mathrm{H}-6,115$ & 80.20 & .93 & 67.12 & H \\
\hline $\mathrm{N}$ & G.sp. A-B(T) & & $823 \mathrm{~A}-11 \mathrm{H}-2,116$ & $823 \mathrm{~A}-11 \mathrm{H}-4,116$ & 95.46 & 1.10 & 89.76 & $\dot{s}$ \\
\hline $\mathrm{N}$ & H.S. & Heliocosphaera selii & $823 \mathrm{~A}-12 \mathrm{H}-3,116$ & $823 \mathrm{~A}-12 \mathrm{H}-4,116$ & 105.71 & 1.27 & 60.88 & $\mathrm{H}$ \\
\hline $\mathrm{N}$ & C.mac. & Calcidiscus macintyrei & $823 \mathrm{~B}-16 \mathrm{X}-6,116$ & $823 \mathrm{~B}-16 \mathrm{X}-\mathrm{CC}$ & 150.88 & 1.48 & 215.10 & $\mathrm{H}$ \\
\hline $\mathrm{F}$ & $G . f .(\mathrm{T})$ & Globigerinoides fistulosus( $\mathrm{T})$ & $823 \mathrm{~B}-17 \mathrm{X}-\mathrm{CC}$ & $823 \mathrm{~B}-16 \mathrm{X}-\mathrm{CC}$ & 153.20 & 1.60 & 19.33 & $\mathrm{H}$ ? \\
\hline $\mathrm{F}$ & G.o. & Globigerinoides obliquus & $823 \mathrm{~B}-22 \mathrm{X}-\mathrm{CC}$ & $823 \mathrm{~B}-21 \mathrm{X}-\mathrm{CC}$ & 204.50 & 1.80 & 256.50 & $\mathrm{DF}$ \\
\hline $\mathrm{N}$ & D.p. & Discoaster pentaradiatus & $823 \mathrm{~B}-24 \mathrm{X}-2,137$ & $823 \mathrm{~B}-24 \mathrm{X}-3,133$ & 222.32 & 2.29 & 36.37 & $\mathrm{H}$ \\
\hline $\mathrm{N}$ & D.s. & Discoaster surculus & $823 \mathrm{~S}-25 \mathrm{X}-5,140$ & $823 \mathrm{~B}-25 \mathrm{X}-2,44$ & 236.17 & 2.42 & 106.54 & $\mathrm{H}$ \\
\hline $\mathrm{N}$ & D.t. & Discoaster tamalis & $823 \mathrm{~B}-26 \mathrm{X}-4,136$ & $823 \mathrm{~B}-26 \mathrm{X}-5,136$ & 244.31 & 2.60 & 45.22 & S? \\
\hline $\mathrm{F}$ & G.f.(B) & Globigerinoides altispira & $823 \mathrm{~B}-30 \mathrm{X}-\mathrm{CC}$ & $823 \mathrm{~B}-31 \mathrm{X}-\mathrm{CC}$ & 290.20 & 2.90 & 152.97 & H? \\
\hline $\mathrm{F}$ & S.sp. & Spheroidinellopsis & $823 \mathrm{~B}-32 \mathrm{X}-\mathrm{CC}$ & $823 \mathrm{~B}-31 \mathrm{X}-\mathrm{CC}$ & 297.50 & 3.00 & 73.00 & $\mathrm{~T}$ \\
\hline $\mathrm{F}$ & G.t.(B) & Globorotalia tosaenisis(B) & $823 \mathrm{~B}-32 \mathrm{X}-\mathrm{CC}$ & $823 \mathrm{~B}-33 \mathrm{X}-\mathrm{CC}$ & 309.30 & 3.10 & 118.00 & \\
\hline $\mathrm{N}$ & R.p. & Reticulofenestra pseusoumbilica & $823 \mathrm{~B}-38 \mathrm{X}-4,126$ & $823 \mathrm{~B}-38 \mathrm{X}-?, 126$ & 359.33 & 3.51 & 122.02 & DF \\
\hline $\mathrm{N}$ & D.a. & Discoaster asymmetricus & $823 \mathrm{~B}-45 \mathrm{X}-\mathrm{CC}$ & $823 \mathrm{~B}-46 \mathrm{X}-\mathrm{CC}$ & 435 . & 3.88 & 205.73 & S? \\
\hline $\mathrm{F}$ & G.n. & Globigerinoides nepenththes & $823 \mathrm{~B}-50 \mathrm{X}-\mathrm{CC}$ & $823 \mathrm{~B}-52 \mathrm{X}-\mathrm{C}$ & 489. & 3.90 & 2702.50 & $\mathrm{H}$ ? \\
\hline $\mathrm{N}$ & A.t. & Amaurolithus tricorniculatus & 823B-54X-CC & $823 \mathrm{~B}-55 \mathrm{X}-\mathrm{CC}$ & 521.60 & 4.24 & 94.41 & $\mathrm{~s}$ \\
\hline $\mathrm{N}$ & C.a.(T) & Ceratolithus armatus $(\mathrm{T})$ & $823 \mathrm{~B}-63 \mathrm{X}-5,125$ & $823 \mathrm{~B}-63 \mathrm{X}-\mathrm{CC}$ & 601.98 & 4.60 & 223.28 & \\
\hline $\mathrm{N}$ & C.a.(B) & Ceratolithus armatus $(B)$ & $823 \mathrm{~B}-66 \mathrm{X}-\mathrm{CC}$ & $823 \mathrm{~B}-67 \mathrm{X}-?, 134$ & 632.87 & 5.06 & 67.15 & $\mathrm{H} / \mathrm{S}$ ? \\
\hline $\mathrm{F}$ & G.tum.(T) & Globorotalia tumida & $823 \mathrm{~B}-69 \mathrm{X}-\mathrm{CC}$ & $823 \mathrm{~B}-70 \mathrm{X}-\mathrm{CC}$ & 675.10 & 5.35 & 145.62 & $\mathrm{H}$ \\
\hline $\mathrm{N}$ & A. $a .(\mathrm{T})$ & Amaurolithus amplificus $(\mathrm{T})$ & $823 \mathrm{~B}-76 \mathrm{X}-\mathrm{CC}$ & $823 \mathrm{~B}-77 \mathrm{X}-\mathrm{CC}$ & 733.05 & 5.60 & 151.80 & s \\
\hline $\mathrm{N}$ & A.a.(B) & Amaurolithus amplificus(B) & $823 \mathrm{~B}-80 \mathrm{X}-\mathrm{CC}$ & $823 \mathrm{~B}-81 \mathrm{X}-\mathrm{CC}$ & 767. & 5.90 & 115.23 & S? \\
\hline $\mathrm{N}$ & D.q.JD.b. & Discoaster quinqueramus/D. bollii & $823 \mathrm{C}-19 \mathrm{R}-\mathrm{CC}$ & $823 \mathrm{C}-20 \mathrm{R}-?, 118$ & 967.44 & 8.20 & 86.88 & $\mathrm{~T}$ ? \\
\hline $\mathrm{N}$ & C.c(T) & Caninaster caliculus & $823 \mathrm{C}-20 \mathrm{R}-?, 121$ & $823 \mathrm{C}-20 \mathrm{R}-5,117$ & 971.92 & 8.75 & 8.15 & $\mathrm{H}$ \\
\hline $\mathrm{N}$ & C. coal $(\mathrm{T})$ & Canina & $823 \mathrm{C}-22 \mathrm{R}-2,140$ & $823 \mathrm{C}-22 \mathrm{R}-3,137$ & 989.84 & 9.00 & 71.68 & $\mathrm{H}$ \\
\hline $\mathrm{F}$ & G.s. & Globorotalia siakensis & 823C-2IR-CC? & & 1008.30 & 10.40 & 13.19 & $\mathrm{~T}$ ? \\
\hline $\mathrm{N}$ & C.coal(B) & Caninaster coalitus(B) & $823 \mathrm{C}-24 \mathrm{R}-2,125$ & $823 \mathrm{C}-24 \mathrm{R}-3,125$ & 1009.10 & 10.80 & 2.00 & $\mathrm{H}$ \\
\hline
\end{tabular}

Note: Sedimentation rates were calculated to the next higher biohorizon. These data were used to interpolate ages of individual gravity flow deposits and petrographic samples.

\section{Unit I}

Unit I is Pleistocene in age and includes a variety of gravity deposits. Two successions of turbidites interbedded with hemipelagic calcareous ooze and marl (mixed muds) are separated by a thick interval that is dominated by slump deposits (Fig. 6). Debris-flow deposits are not common, but occur both above and below the slumped interval.

Turbidites in Unit I are composed of bioclastic grainstone/packstone with variable amounts of quartz and foraminifers (Pl. 1, Fig. B; Fig. 6). Quartz is most abundant in bioclastic mixed sandstones with foraminifers at 34 and $37 \mathrm{mbsf}$, but also occurs at other intervals. 
Table 3. Depths of lower boundaries of lithologic units with inferred ages and sedimentation rates and two-way traveltime of lower boundaries of seismic sequences and their calculated depths.

\begin{tabular}{|c|c|c|c|c|c|c|}
\hline \multicolumn{2}{|c|}{$\begin{array}{l}\text { Lithologic } \\
\text { unit }\end{array}$} & $\begin{array}{c}\text { Depth at } \\
\text { base (mbsf) }\end{array}$ & $\begin{array}{l}\text { Thickness } \\
\text { (m) }\end{array}$ & $\begin{array}{c}\text { Age at } \\
\text { base (Ma) }\end{array}$ & $\begin{array}{l}\text { Duration } \\
\text { (m.y.) }\end{array}$ & $\begin{array}{l}\text { Sed. rate } \\
(\mathrm{m} / \mathrm{m} . \mathrm{y} .)\end{array}$ \\
\hline IA & & 85.40 & 85.40 & 0.99 & 0.99 & 86.26 \\
\hline IB & & 120.77 & 34.60 & 1.34 & 0.35 & 98.86 \\
\hline II & & 352.75 & 232.05 & 3.46 & 2.12 & 109.46 \\
\hline IIIA & & 440.30 & 88.30 & 3.88 & 0.42 & 210.23 \\
\hline IIIB & & 516.80 & 76.50 & 4.18 & 0.30 & 255.00 \\
\hline IIIC & & 535.70 & 18.90 & 4.30 & 0.12 & 157.50 \\
\hline IV & & 715.00 & 179.30 & 5.52 & 1.22 & 146.97 \\
\hline V & & 797.70 & 82.70 & 6.24 & 0.72 & 114.86 \\
\hline VI & & 887.00 & 89.30 & 7.27 & 1.03 & 86.70 \\
\hline VIIA & & 978.00 & 91.00 & 8.83 & 1.56 & 58.33 \\
\hline VIIB & & 1011.00 & 33.00 & 10.81 & 1.98 & 16.67 \\
\hline $\begin{array}{l}\text { Seismic } \\
\text { sequence }\end{array}$ & $\begin{array}{l}\text { TWT to } \\
\text { base (s) }\end{array}$ & $\begin{array}{c}\text { Depth at } \\
\text { base (mbsf) }\end{array}$ & $\begin{array}{c}\text { Thickness } \\
\text { (m) }\end{array}$ & $\begin{array}{c}\text { Age at } \\
\text { base (Ma) }\end{array}$ & $\begin{array}{c}\text { Duration } \\
\text { (m.y.) }\end{array}$ & $\begin{array}{l}\text { Sed. rate } \\
(\mathrm{m} / \mathrm{m} . \mathrm{y} .)\end{array}$ \\
\hline 1 & 2.29 & 27.00 & 27.00 & 0.42 & 0.42 & 64.29 \\
\hline 2 & 2.34 & 85.00 & 58.00 & 0.98 & 0.56 & 103.57 \\
\hline 3 & 2.48 & 208.00 & 123.00 & 1.90 & 0.92 & 133.70 \\
\hline $3 \mathrm{~A}$ & 2.54 & 295.00 & 87.00 & 2.97 & 1.07 & 81.31 \\
\hline 4 & 2.62 & 343.00 & 48.00 & 3.38 & 0.41 & 117.07 \\
\hline 5 & 2.74 & 471.00 & 128.00 & 3.89 & 0.51 & 250.98 \\
\hline 6 & 2.91 & 659.00 & 188.00 & 5.24 & 1.35 & 139.26 \\
\hline $\begin{array}{l}7 \\
8\end{array}$ & $\begin{array}{l}3.02 \\
3.04\end{array}$ & 829.00 & 170.00 & 6.62 & 1.38 & 123.19 \\
\hline 9 & 3.10 & 901.00 & 72.00 & 7.43 & 0.81 & 88.89 \\
\hline 10 & 3.20 & E1020.00 & E1 19.00 & E11.40 & E3.97 & E29.97 \\
\hline
\end{tabular}

Note: Inferred ages and sedimentation rates were calculated (to the next higher unit) by linear interpolation between biohorizons listed in Table 2. E = estimated.

Bedding thickness and grain size increase in the lower part of the unit, with an abrupt reduction at 113 mbsf. The abundance, grain size, and thickness of turbidites decrease in the middle part of the unit (48-103 mbsf), which is dominated by debris-flow and slump deposits. Another succession of turbidites at 30 to 48 mbsf shows upwardcoarsening/thickening, followed by upward-fining/thinning trends. The upper 15 mbsf contains relatively few turbidites.

Debris-flow deposits (intraclastic conglomerates) occur at several intervals in Unit I (Fig. 6). Interestingly, they bracket and grade into the thick slump deposits at 48 to 52 mbsf and 95 to 97 mbsf. Above the higher debris flow, a thick bed of $(58.4 \mathrm{~cm})$ turbiditic bioclastic sand fills burrows that cut into the debris flow. The thickest debris-flow deposit (15-24 mbsf; $814 \mathrm{~cm}$ thick) contains large folded slabs of clayey calcareous ooze with turbidite interbeds and smaller, rounded clasts of mixed mudstone. Near the top of the hole (1.25-1.85 mbsf), an unusual debris-flow conglomerate contains large granules of quartz, volcanic lithic fragments, Halimeda, and a boulder of green mixed mudstone that is slightly older than the associated hemipelagic sediments at the base of the core $(0.3$ vs. $<0.275 \mathrm{Ma}$ at $10.55 \mathrm{mbsf})$, suggesting erosion farther upslope.

Hemipelagic sediments in Unit I show a wide range of compositions (Fig. 6). Clayey calcareous ooze (carbonate contents range between $60 \%$ and $80 \%$ ) is most abundant and contains both nannofossils and platform-derived aragonite with variable amounts of clay and quartz silt. Marls/mixed muds (40\%-60\% carbonate) occur in the upper and lower parts of Unit I. Calcareous claystone ( $<40 \%$ carbonate) occurs at the base of the unit and within a slump block at 84 to 90 mbsf. No obvious relationship exists between the composition of hemipelagic sediments and different types of gravity deposits.

\section{Unit II}

Unit II is the thickest unit at Site $823(232 \mathrm{~m})$, and ranges in age from late Pliocene to early Pleistocene (Fig. 7). Debris-flow and slump deposits are abundant in the upper part of the unit, but also occur at other levels. Turbidites are particularly abundant in Unit II and show significant variations in composition, grain size, and bed thickness.
Turbidites are more abundant in Unit II than in any other unit ( 700 turbidites), particularly in the middle part ( $200-300 \mathrm{mbsf})$. In the upper part, turbidites are mixed sandstones that contain bioclasts, quartz, and foraminifers. Bioclasts include fragments of echinoderms, ostracods, gastropods, and rare red algae (Pl. 1, Fig. A). Neritic foraminifers and large foraminifers are typical constituents as are glauconitic and phosphatic grains (similar to Pl. 2, Fig. A). The composition of turbidites changes between 191 and 241 mbsf. Foraminifers increase in abundance downhole, with a concomitant reduction in bioclasts and quartz (Fig. 7). Interestingly, foraminifers within this transitional interval show a decrease in abrasion and fragmentation downhole that continues to a depth of $\sim 240$ mbsf (Core 133-823B26X). In the lower part of Unit II (241 mbsf), turbidites consist of foraminiferal chalk with generally rare quartz, bioclasts and neritic foraminifers. In Cores $32 \mathrm{X}$ and $33 \mathrm{X}$, turbidites show a progressive downhole decrease in abundance, bed thickness, and grain size. Farther downhole to the base of Unit II, turbidites become increasingly rare, thinner, and finer-grained.

Debris-flow and slump deposits are common in the upper part of Unit II (131-188 mbsf). These deposits are interbedded with and contain clasts of mixed mudstone and calcareous claystone. Turbidite interbeds within slumped intervals are folded, inclined, and overturned in places. Two thin debris-flow deposits within the transitional interval (213.2-214.9 and 207.9-209.6 mbsf) contain intraclasts of mixed mudstone and claystone. Slumped intervals with inclined and overturned turbidite beds immediately below the transitional interval (239$256 \mathrm{mbsf}$ ) are composed primarily of clayey calcareous chalk. In the lower part of the unit (318-337 mbsf), slumped intervals are composed primarily of relatively calcareous clayey chalk and exhibit large-scale folds, inclined laminations, and have overturned turbidite beds.

Hemipelagic sediments in Unit II are compositionally variable and contain admixtures of terrigenous mud, pelagic carbonate, and aragonitic periplatform ooze. Aragonite is less abundant in Unit II than in Unit I and was not recognized below 256 mbsf in Unit II (Shipboard Scientific Party, 1991, p. 714). Hemipelagic mixed mudstone and lesser calcareous claystone are interbedded with the slump and debrisflow deposits in the upper part of the unit (120-183 mbsf). In the middle and lower parts of the unit, clayey calcareous chalk is the dominant hemipelagic sediment, interbedded with turbidites. Mixed mudstone and calcareous claystone also occur in the lower half of the unit, as illustrated in Figure 7. Calcareous claystone is particularly abundant from 231 to 238 mbsf.

Biostratigraphic age control in Unit II is generally well constrained, but two problem areas deserve mention. The Discoaster brouweri biohorizon (indicating an age of $1.88 \mathrm{Ma}$ ) first occurs within a debris flow at 163 mbsf. Because this biohorizon is located a short distance $(12.1 \mathrm{~m})$ below the Calcidiscus tropicus biohorizon (indicating an age of $1.48 \mathrm{Ma}$ ) and suggests an unusually rapid sedimentation rate, these nannofossils may have been reworked from older deposits. The first occurrence of the planktonic foraminifer Globigerinoides obliquus (indicating $1.8 \mathrm{Ma}$ ) is located at $204.5 \mathrm{mbsf}$ (possibly as high as 190 mbsf; D. Kroon, pers. comm., 1992), supporting an interpretation of reworking of Discoaster brouweri. However, the ages of the interval between 222 and $244 \mathrm{mbsf}$ are well constrained between three closely spaced biohorizons (indicating ages of $2.29,2.42$, and 2.60 $\mathrm{Ma}$ ), which allows for precise dating of the influx of turbiditic quartzose and bioclastic turbidite sands (Fig. 7).

\section{Unit III}

Unit III is the second thickest unit at Site $823(183 \mathrm{~m})$ and is mostly early Pliocene in age, but spans the late Pliocene boundary near the top. The unit is dominated by debris-flow and slump deposits in its upper and lower parts (Subunits IIIA and IIIC). Hemipelagic sediments with interbedded turbidites and lesser debris-flow and slump deposits characterize the lower middle part (Subunit IIIB, Fig. 8). 


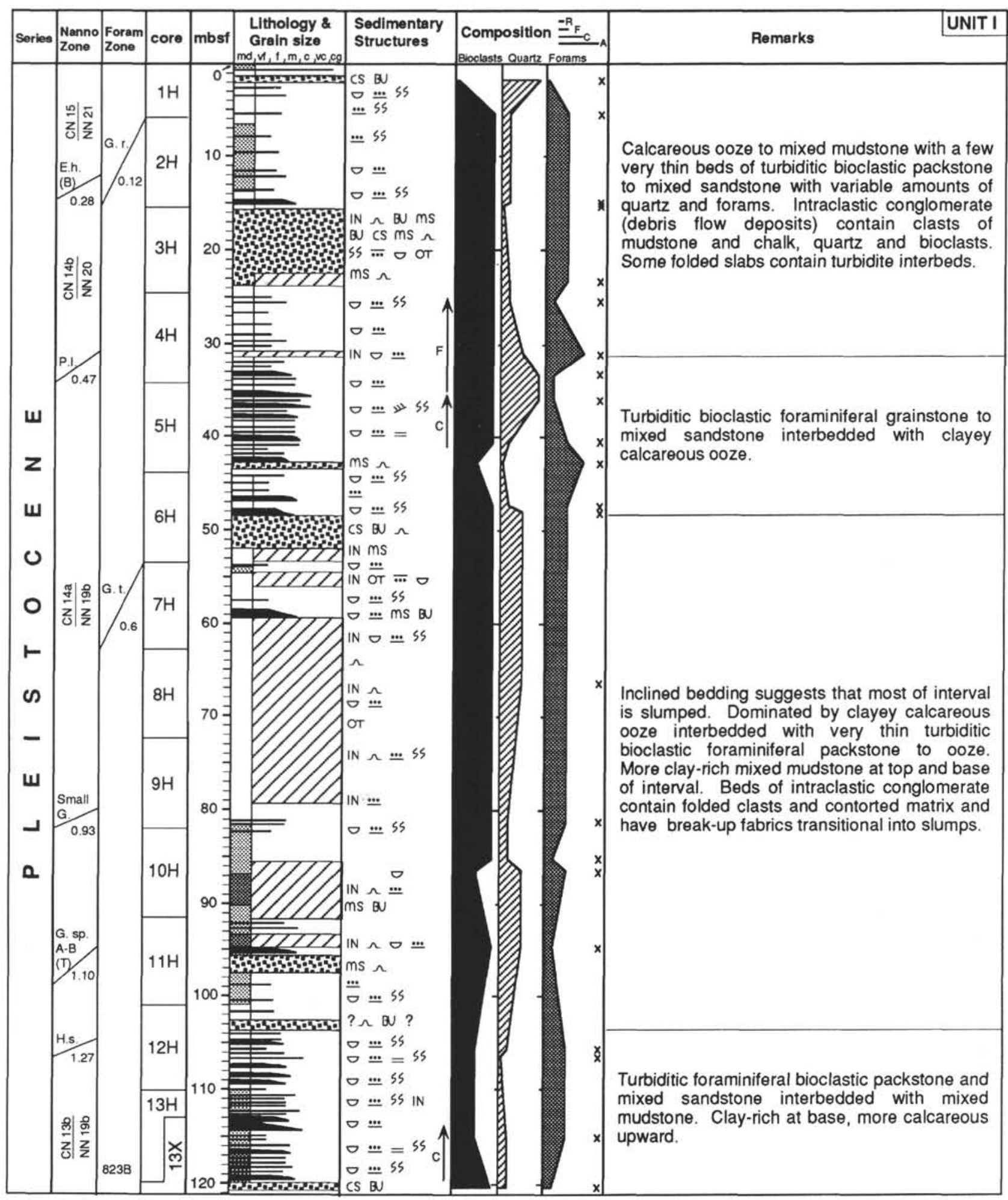

Figure 6. Generalized stratigraphic column for Unit I. Note the decline in abundance of turbidites immediately beneath the debris-flow and slump deposits. See Figure 4 for key to symbols. 


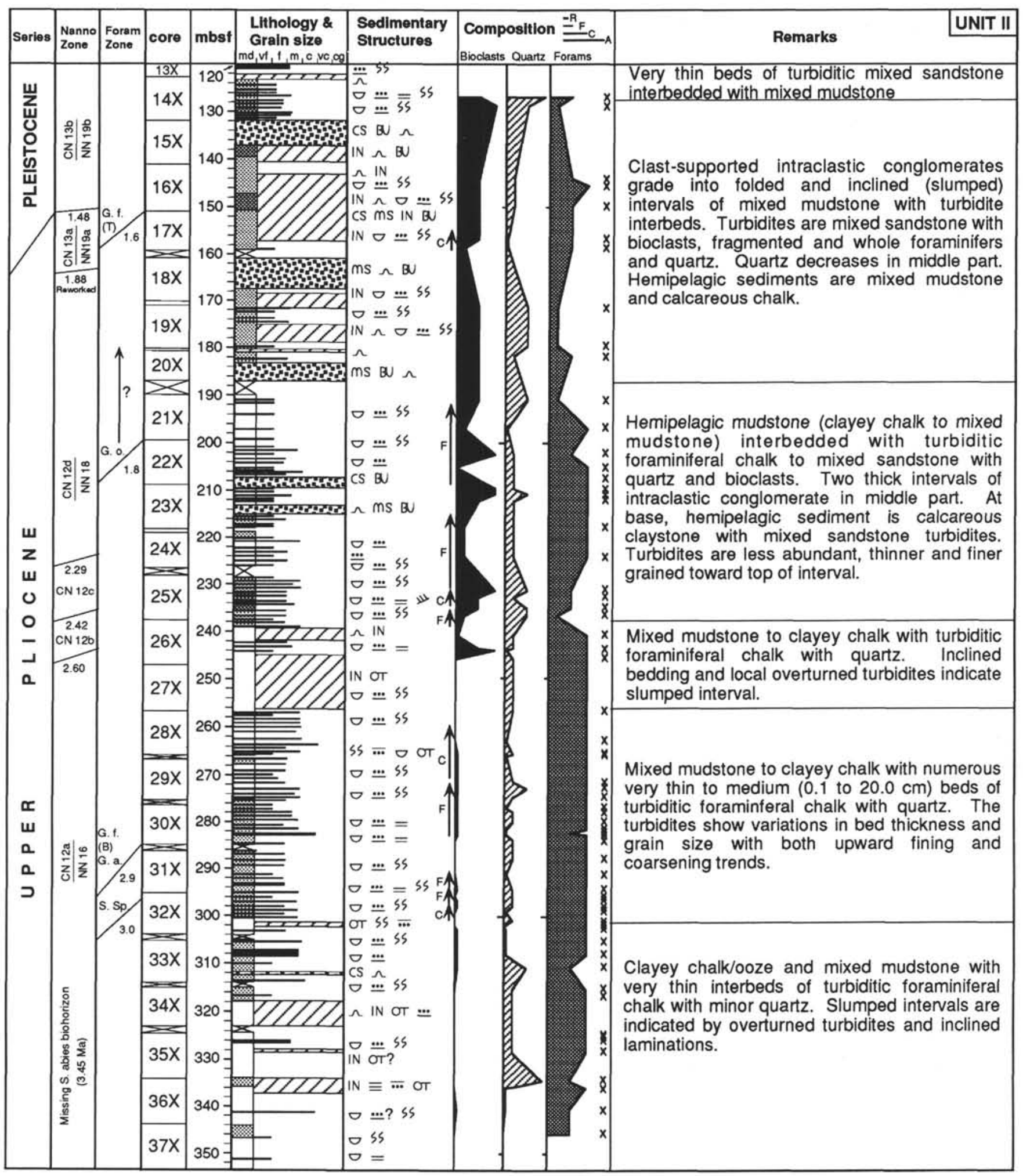

Figure 7. Generalized stratigraphic column for Unit II. Note the abundance of turbidites, abrupt appearance of bioclasts at 245 mbsf, and debris-flow and slump deposits above 187 mbsf. The vertical scale for this thick unit is different from others. See Figure 4 for key to symbols. 


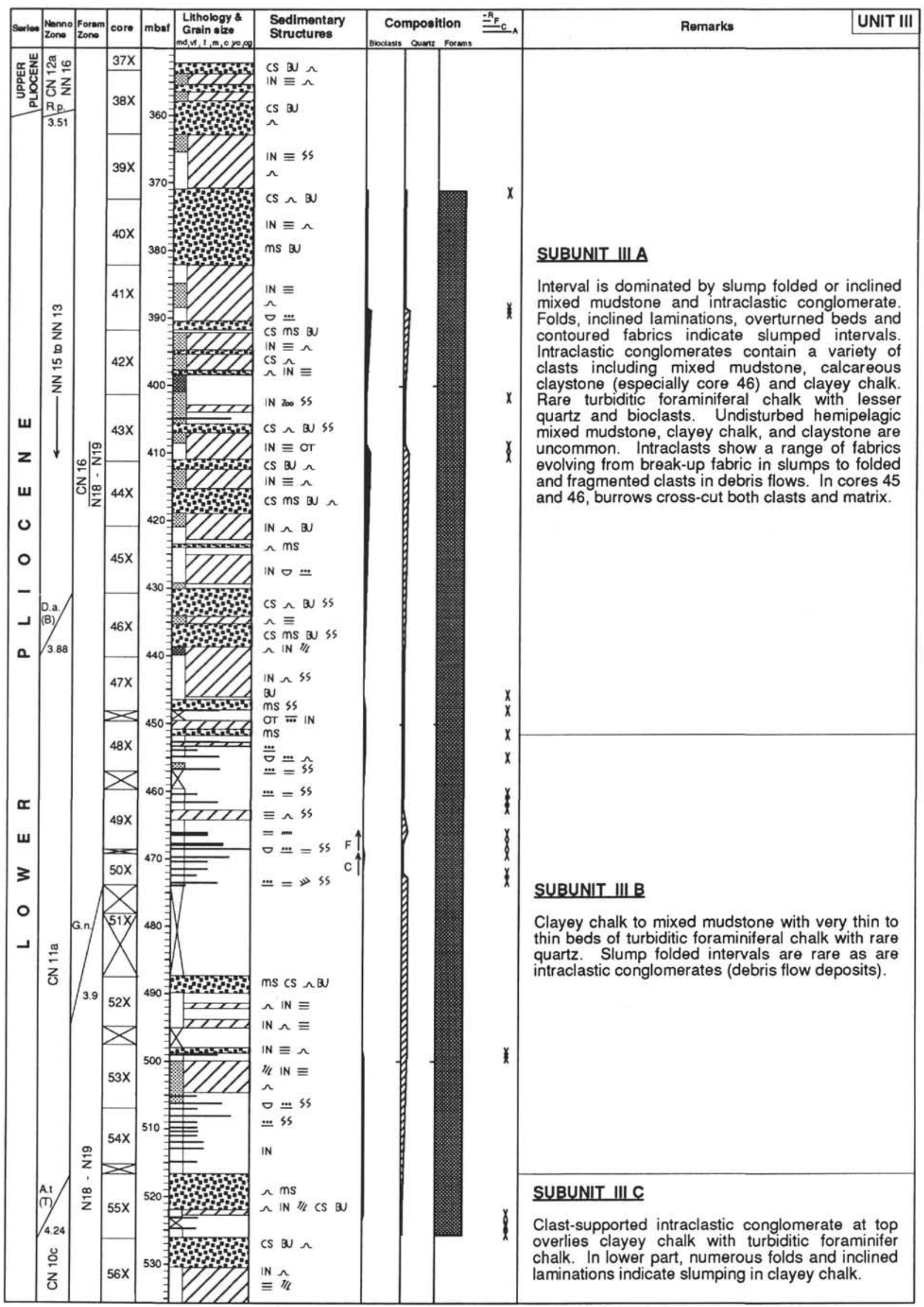

Figure 8. Generalized stratigraphic column for Unit III. Note abundance of debris-flow and slump deposits above $453 \mathrm{mbsf}$. The vertical scale for this thick unit is different from others. See Figure 4 for key to symbols. 
Turbidites are much less abundant in Unit III than in Unit II, but several turbidites are interbedded with clayey calcareous chalk in Subunit IIIB (448-515 mbsf, Fig. 8). These turbidites are primarily foraminiferal chalk with generally rare bioclasts and quartz. Beds are typically very thin ( $<5 \mathrm{~cm}$ ), but thicker beds (up to $21 \mathrm{~cm}$ ) from 464 to $470 \mathrm{mbsf}$ are organized into upward-thinning/fining successions. A few deformed and inclined turbidite beds occur within the slumped intervals described below.

Interbedded debris-flow and slump deposits are clearly genetically related and show a range of associated sedimentary structures and transitional fabrics. Intraclastic conglomerates (debris-flow deposits) contain abundant clasts of mixed mudstone and claystone, lesser clasts of turbiditic foraminiferal chalk, and rare phosphatic clasts and pyritized bioclasts. Folded clasts and blocks breaking up into smaller clasts indicate that many intraclastic conglomerates began moving downslope as slumps and then disintegrated into debris flows. Some large ( $>1 \mathrm{~m}$ thick) slump blocks may be large clasts within debris-flow deposits. Compositionally, the slump blocks and associated hemipelagic sediments are composed of mixed mudstone and lesser clayey calcareous chalk (particularly in the lower part of the unit). Mixed mudstone appears to be less competent than either clayey calcareous chalk or claystone and forms the matrix of many of the debris-flow deposits. Several thick debris-flow deposits between 415 and 448 mbsf have bioturbation that crosscuts both clasts and matrix to depths of up to $4.5 \mathrm{~m}$ (PI. 4, Fig. B). The highest occurrence of brittle deformation and microfaulting at Site 823 is in a slumped interval at 395 mbsf (see "Tectonics" section, this chapter). In Subunit IIIC, two thick slump deposits are each overlain by coeval debris-flow deposits.

Hemipelagic sediments range in composition from clayey calcareous chalk to mixed mudstone. As stated previously, mixed mudstone intervals are associated with slump and debris-flow deposits. Hemipelagic sediments in Subunit IIB are clayey calcareous chalk that are interbedded with thin turbidites. The only mixed mudstone interval in Subunit IIIB appears to be a slump deposit with inclined bedding and folds.

Biostratigraphic age control for Unit III is less precise than for younger sediments at Site 823. Biohorizons in Subunit IIIA occur within debris-flow and probable slump deposits and therefore may be reworked (Table 2). The foraminifer biohorizon Globigerinoides nepenthes (3.9 Ma) occurs within hemipelagic sediments of Subunit IIIB at $\sim 889.5 \mathrm{mbsf}$. This is much deeper than the Discoaster assymetricus biohorizon ( $3.88 \mathrm{Ma}$ ), which occurs within a probable slumped interval at $\sim 435.45$ mbsf, suggesting reworking of the latter. The absence of the Spenolithus abies biohorizon (3.45) may be related to erosion or nondeposition in Subunit IIIA.

\section{Unit IV}

Unit IV is dominated by the clayey calcareous chalk and mixed mudstone that are commonly internally deformed in slumped intervals (Fig. 9). Turbidites are relatively rare, as are debris-flow conglomerates. The unit is $179 \mathrm{~m}$ thick and spans the upper Miocene/ lower Pliocene boundary.

These turbidites are composed primarily of foraminiferal chalk (PI. 1, Fig. C), but exhibit abrupt downhole increases in quartz content in the uppermost Miocene section. The turbidites are generally thinly bedded (generally $<5 \mathrm{~cm}$ ) and are typically interbedded with clayey calcareous chalk. They are organized into thin upward-coarsening/ thickening and upward-fining/thinning successions (Fig. 9). In Core $71 \mathrm{X}$, amalgamated beds of relatively thick turbidites contain stretched pebbles and folded blocks. Rare turbidite beds also occur in slump blocks, described below.

Slumped intervals are the dominant gravity deposit in Unit IV, as indicated by soft-sediment deformation, overturned bedding, and inclined laminations. Some slump blocks contain turbidite beds that are inclined or overturned. Relatively thin $(50 \mathrm{~cm})$ and rare intraclastic debris-flow conglomerates are interbedded with hemipelagic mixed mudstone and commonly grade into slumped intervals. In Core $65 \mathrm{X}$, an unusually thick interval of relatively calcareous debris-flow conglomerate is interbedded with an overturned turbidite that indicates later slump-folding of the entire interval. Folded intraclasts, clast break-up fabrics, shearing, and local brittle microfaulting illustrate a close association between debris-flow and slump deposits.

Hemipelagic sediments are relatively calcareous clayey chalk (up to $85 \%$ carbonate) and mixed mudstone. Turbidites are typically interbedded with clayey calcareous chalk, except in the lower part of the unit (Miocene), where mixed mudstone is interbedded with both turbidites and debris-flow deposits.

Unit IV ranges in age from early Pliocene to late Miocene. The nannofossil biohorizons are clustered in the middle of the unit, and only one planktonic foraminifer biohorizon is represented. The foraminifer Globorotalia tumida (5.2 Ma) first appears at $679.9 \mathrm{mbsf}$, which is deeper than the first occurrence ( $653.75 \mathrm{mbsf}$ ) of the nannofossil Discoaster quinqueramus (5.26 Ma). Although the latter occurs within hemipelagic clayey calcareous chalk, nearby shearing and folding may indicate that it is within a slumped interval and possibly has been reworked. The G. tumida sample was from undisturbed hemipelagic chalk and may be a better datum. Unfortunately, the other two biohorizons occur within gravity deposits (a slump and a turbidite) and indicate imprecise maximum ages.

\section{Unit V}

Unit $\mathrm{V}$ is 80.7 thick and late Miocene in age. It is a monotonous unit that consists primarily of hemipelagic mixed mudstone and calcareous claystone, most of which have been deformed as part of slump blocks (Fig. 10). In contrast to other units at Site 823, turbidites and debris-flow deposits are extremely rare.

The rare turbidites primarily consist of foraminiferal chalk. A few thin $(<2 \mathrm{~cm})$ beds of mixed sandstone to siltstone indicate an influx of quartz near the top of the unit (728-731 mbsf).

Inclined lamination, overturned bedding and folds indicate that slump deposits dominate Unit V (Pl. 3, Figs. A and B). Microfaulting also occurs at several levels, particularly at the top of the unit. Debris-flow conglomerates are rare and contain folded clasts within a highly deformed matrix, beneath relatively calcareous clayey chalk at 731 mbsf.

Hemipelagic sediments are dominated by terrigenous mud and silt and generally range from calcareous claystone to mixed mudstone. Very fine-grained, muddy, mixed sandstone in Core $82 \mathrm{X}$ and within several slumped intervals has an unknown depositional mechanism, but could represent homogeneous mud flow deposits.

Age control in Unit $\mathrm{V}$ includes two nannofossil biohorizons within probable slumped intervals. The next age datum downhole is significantly deeper at 967 mbsf (Unit VII); thus, sedimentation rates are poorly constrained.

\section{Unit VI}

Unit VI (101.4 m thick) was informally termed the "zebra unit." White chalk alternates with dark turbidites and debris-flow deposits (Fig. 11). Although no age control is available for the unit, its late Miocene age is bracketed between biohorizons in Units V and VII (5.9-8.2 Ma). Debris-flow and slump deposits are common in the lower part (below $823 \mathrm{mbsf}$ ) and turbidites are dominant toward the top.

Turbidites occur throughout Unit VI, but are most abundant near the top (794-809 mbsf), where they are organized into an upwardcoarsening succession (Fig. 11). In the middle and lower parts of the unit (below and including Cores 133-823C-6R; >834 mbsf), turbidites are interbedded with debris-flow deposits and show both upward-fining and upward-coarsening trends. One thick turbidite bed $(60 \mathrm{~cm})$ contains large rounded pebbles (intraclasts) of chalk the base (Pl. 4, Fig. C). The turbidites are foraminiferal chalk to mixed sandstone containing abundant foraminifers throughout the unit $(\mathrm{Pl}$. 


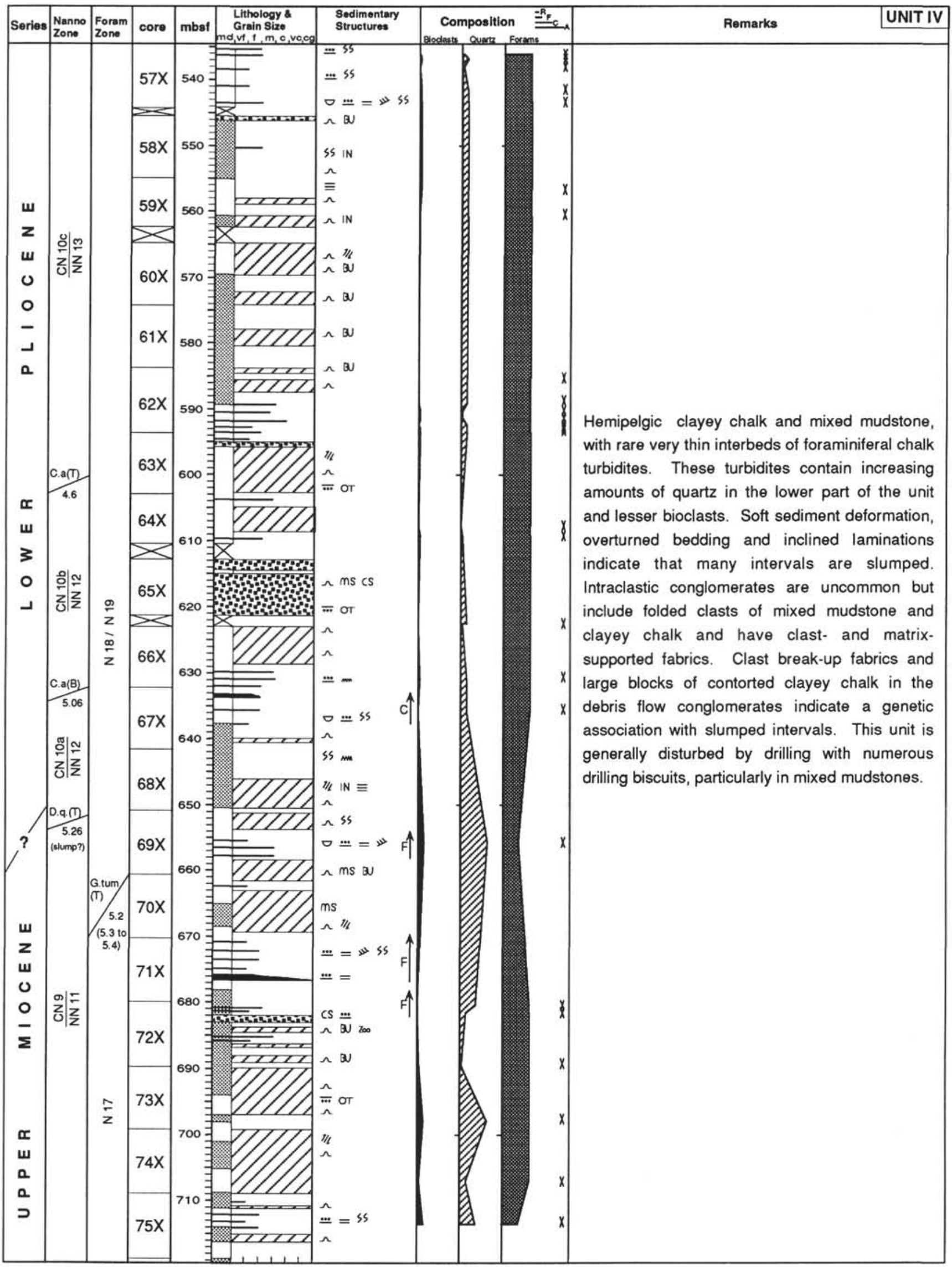

Figure 9. Generalized stratigraphic column for Unit IV. Note abundance of slump and paucity of turbidites and debris-flow deposits. The turbidites are composed mostly of foraminifers, with a slight influx of quartz sand in the lower part. See Figure 4 for key to symbols. 


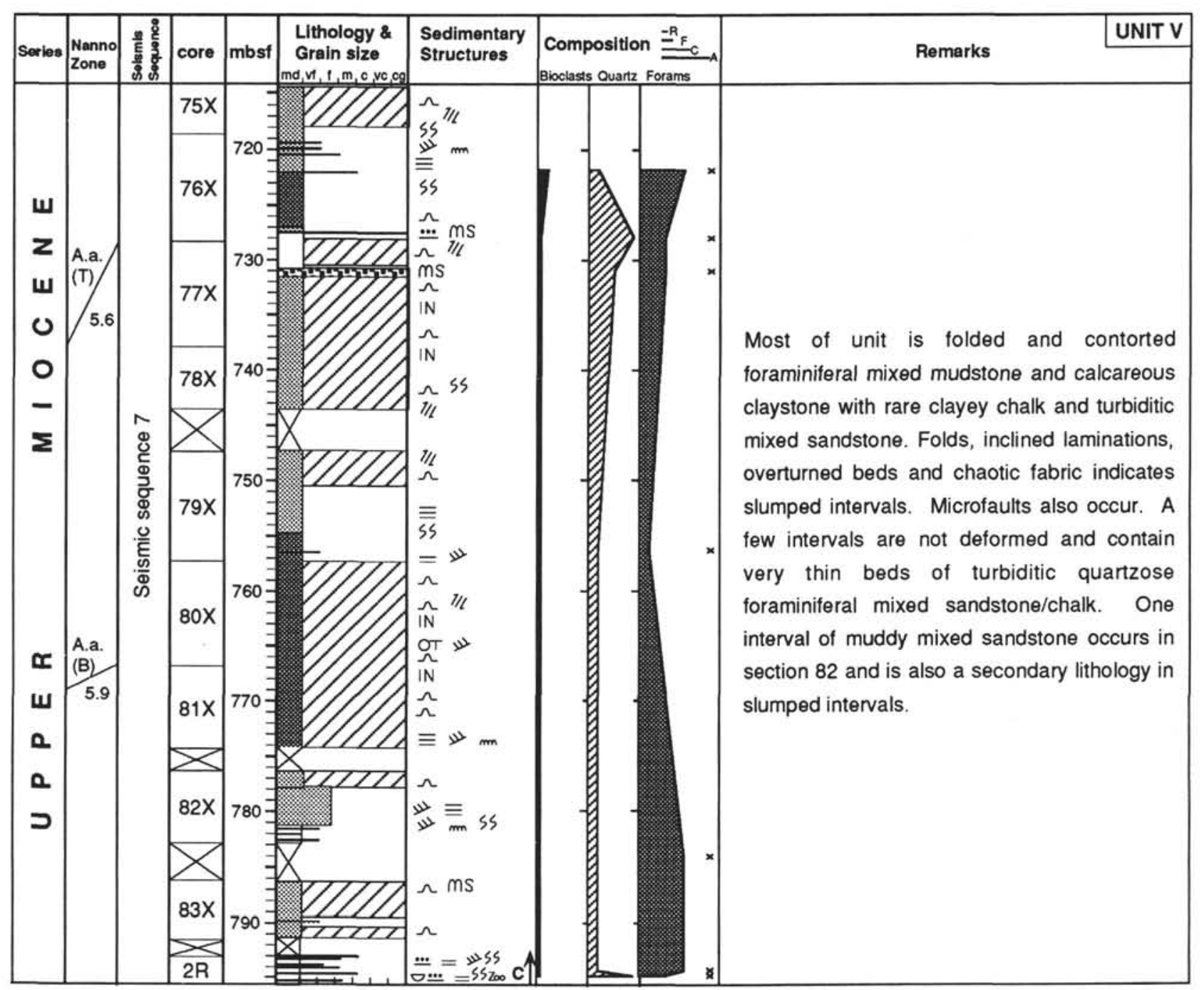

Figure 10. Generalized stratigraphic column for Unit V. Note prevalence of slumping and rarity of turbidites. The turbidites are composed mostly of foraminifers with a slight influx of quartz in the upper part. See Figure 4 for key to symbols.

1, Fig. D). Quartz is relatively abundant in the lower part of the unit (below $870 \mathrm{mbsf}$ ). Igneous lithic fragments are a rare constituent. Bioclasts are generally rare, but show a slight increase between 830 and $850 \mathrm{mbsf}$. Bioclasts include red algae, echinoderms, and bivalves in addition to large neritic foraminifers. This lower part of Unit VI is similar to upper Unit VII in many respects. Unit VII is distinguished by its clasts of neritic limestone (see below).

Intraclastic conglomerates (debris flow) are common in the lower part of Unit VI (842-883 mbsf), and slump deposits dominate the middle part (823-833 mbsf). Slumped intervals display inclined lamination, folds, contortion and clast break-up fabrics. Microfaulting is particularly well developed in the slumped intervals and may be related to shearing along fold axes. Intraclastic conglomerates (debris-flow deposits) contain a variety of intraclasts, including chalk, mixed mudstone, and claystone, many of which show small-scale folding and break-up fabrics (Pl. 3, Fig. C, and Pl. 4, Fig. A). Both clast- and matrix-supported fabrics are evident. In most cases, the matrix material is sandy mudstone with relatively large neritic foraminifers (Pl. 4, Fig. A). At 847 mbsf, one thick debris flow with a sandy matrix passes upward into a turbidite (see Krause and Oldershaw, 1979). In Core 133-823C-9R ( $864 \mathrm{mbsf}$ ), a deep scour cuts into the underlying hemipelagic sediment.

Hemipelagic sediments are primarily white nannofossil chalk to clayey calcareous chalk and lesser dark greenish-gray calcareous claystone to siltstone. The latter are more common in the upper and lower parts of the unit, but cannot be shown at the scale of Figure 11. These mixed mudstones typically cap sandy turbidites (see above) and may represent muddy turbidites deposited by dilute turbidity currents. The white clayey calcareous chalk clearly is pelagic with abundant nannofossils and commonly is strongly bioturbated into underlying turbiditic muds and/or sands. These chalks consistently have the highest carbonate contents (up to $96 \%$ ) of the hemipelagic sediments at Site 823 , which suggests slower sedimentation rates without the admixture of terrigenous muds.

Unfortunately, age control is absent in Unit VI. Its late Miocene age is constrained by biohorizons in Units V (5.9 Ma at $768 \mathrm{mbsf}$ ) and VII (8.2 Ma at $968 \mathrm{mbsf}$ ). Compounding the problem, sedimentation rates in the lower part of Unit VII are significantly lower than those in Unit V (Fig. 12). The maximum (albeit unlikely) possible age range of Unit VII is bracketed by the 5.9- to 8.2-Ma biohorizons. Assuming a constant sedimentation rate between these two biohorizons, its age range is 6.0 to $7.1 \mathrm{Ma}$ (the age-converted plots in Fig. 16 assume this; see below). Alternatively, extrapolating sedimentation rates downward from the overlying units (average sedimentation rate of $\sim 130 \mathrm{~m} / \mathrm{Ma}$ ) to an intercept of the sedimentation rate of $16 \mathrm{~m} / \mathrm{m} . \mathrm{y}$. in Unit VII would indicate a narrower age range of 5.9 to $6.6 \mathrm{Ma}$ for Unit VI. However, the calcareous chalk within Unit VI indicates relatively slow sedimentation rates compared to the voluminous 


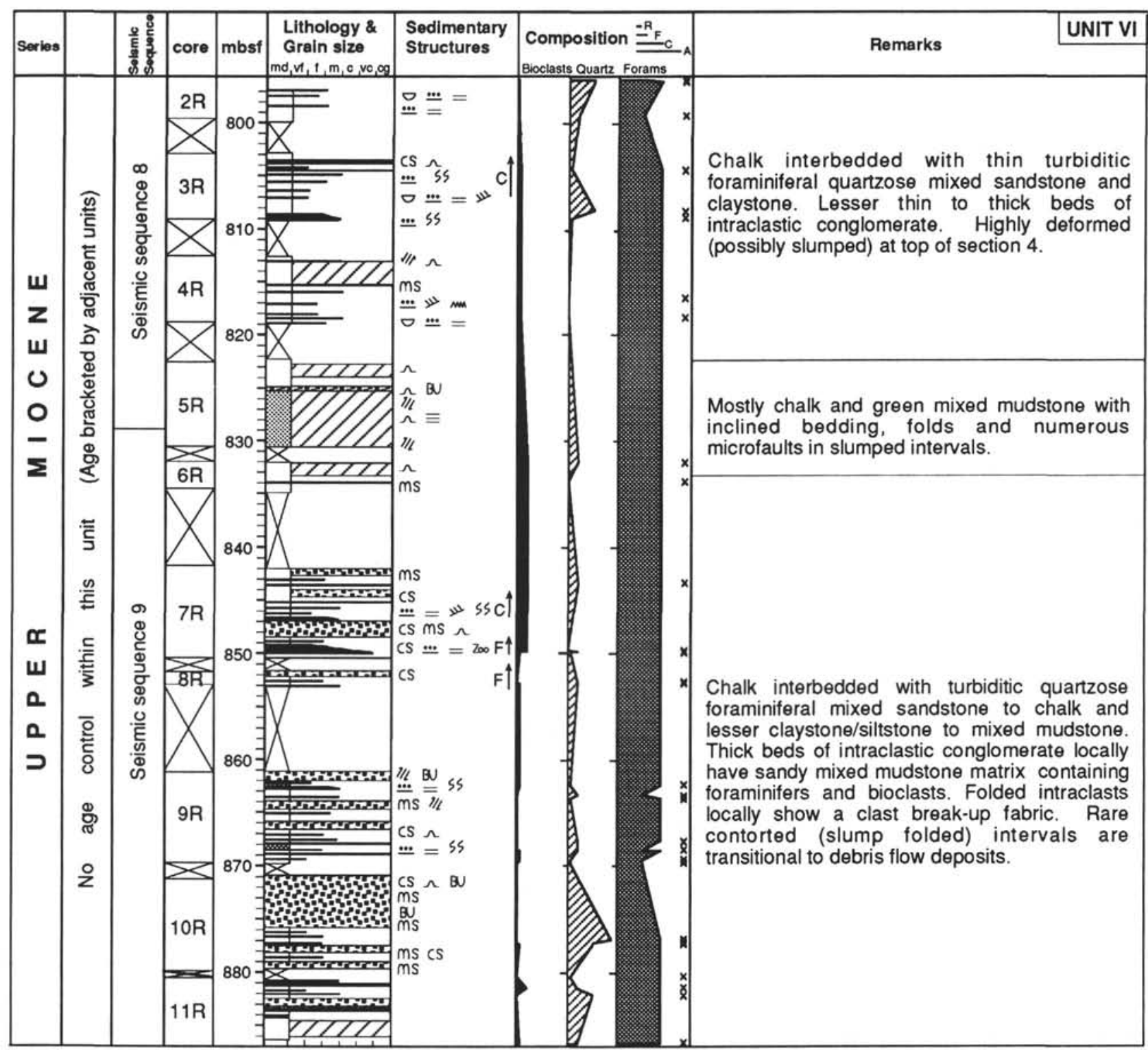

Figure 11. Generalized stratigraphic column for Unit VI. Note alternating clayey calcareous chalk and turbidites near top and interbedded debris-flow deposits, turbidites, and clayey calcareous chalk in lower part. Also note the position of seismic sequences. See Figure 4 for key to symbols.

terrigenous mixed muds in the younger units. A hiatus may exist between sequences 9 and 11 , as indicated by the lateral pitch-out of sequence 10 (upper Unit VII, Fig. 13). Thus, slower sedimentation rates may have existed during the deposition of Unit VI, which would imply a longer age range for the unit.

Seismic data for the lower units at Site 823 provide additional insights about the distribution and origin of its gravity deposit. All of the upper seismic sequences (sequences 1 to 8 ; Units I to V) were deposited over the gently eastward- to northeastward-sloping floor of the Queensland Trough (Figs. 2 and 13). Sediments supplied from the northeastern Australia margin generally are thinner to the east, and this slope represents the angle of repose/base level of hemipelagic muds, turbidites, and debris-flow deposits. The geometry of the lower seismic sequences indicate that a major pulse of late Miocene tectonic tilting and block faulting occurred before the deposition of sequence 9 (Unit VI) and after the deposition of sequence 11 (below Unit VII?). Sequence 9 is ponded sediments that onlap eastward over the tilted fault block (Fig. 13). To the west, this sequence laps onto an unusual lobate body of sediment (sequence 10/upper Unit VII?) that may represent a large submarine slide deposit (Figs. 14C and 14D, see below). The strong reflectors in sequence 9 result from the well-bedded nature of Unit VI, with its interbedded chalk, turbidites, and debris-flow deposits. By filling the structural depression, the ponded sediments of sequence 9 established an eastward-sloping surface. Minor movements along the preexisting faults that extend up to sequence 5 (Unit III) permitted continued differential subsidence of this part of the Queensland Trough. Sequences 7 to 9 (Units IV to VI) onlap eastward onto the uplifted fault blocks.

\section{Unit VII}

The distinguishing features of Unit VII are clasts of neritic limestone that occur in turbidites and debris-flow deposits (Pl. 2, Fig. B). In our detailed studies, we discovered that clasts of neritic limestone occur as high as $887 \mathrm{mbsf}, 12 \mathrm{~m}$ higher than where the Unit VI/Unit VII boundary was originally defined (Fig. 15; Shipboard Scientific 


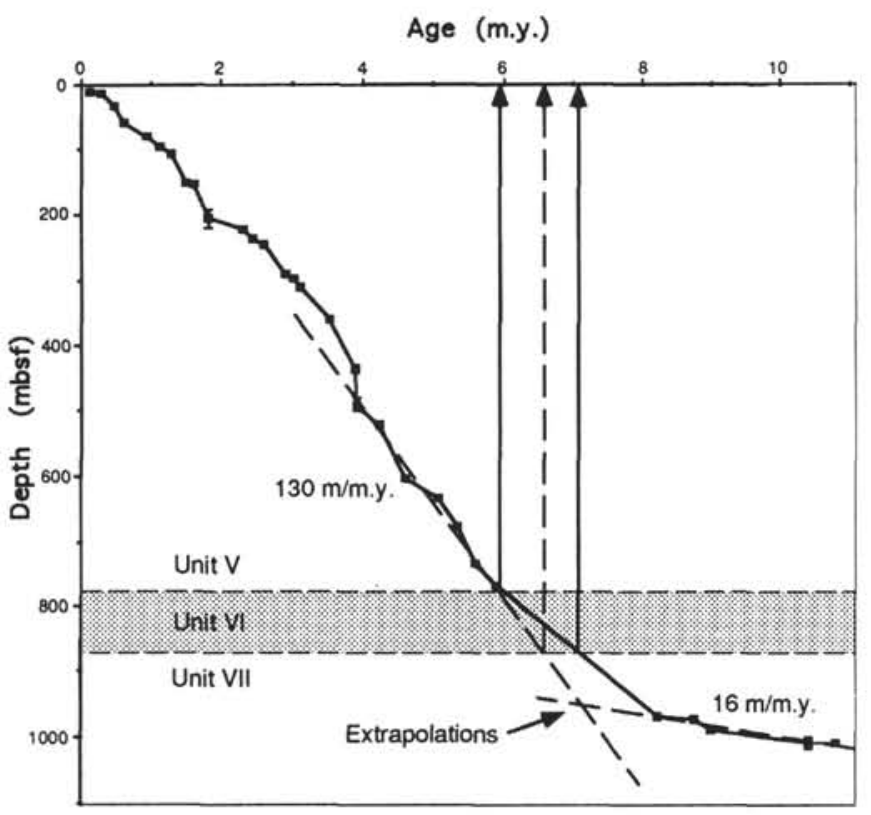

Figure 12. Sedimentation rates and biostratigraphic age control used in this study. Note lack of age control and different age estimates for Units VI and VII. The low sedimentation rates implied by pelagic chalk in Unit VI and irregularities in associated seismic sequences (Fig. 13) indicate that unconformities may exist in Units VI and VII. See Table 2 for listing of biohorizons with depths, inferred ages, and calculated sedimentation rates.

Party, 1991). Debris-flow and slump deposits are abundant in the upper part of the unit, whereas turbidites and lesser debris-flow conglomerates dominate the lower part of the unit. Age control is limited to the lower part with ages that range from the late to middle Miocene (8.2-10.8 Ma), indicating a relatively low average sedimentation rate of $16 \mathrm{~m} / \mathrm{m} . \mathrm{y}$. (Table 2 ).

Turbidites in Unit VII are mixed foraminiferal sandstone with varying amounts of quartz and bioclasts and lesser intraclasts of neritic limestone (Pl. 2, Fig. C). Large neritic foraminifers, echinoderms, red algae, rhodoliths, bivalves, and rare coral fragments were derived from neritic carbonate(?) platform sources (Pl. 2, Fig. C). Relatively coarse-grained terrigenous quartz is most abundant in the lower part of the unit, along with rare plagioclase and metamorphic rock fragments (Pl. 2, Fig. D). Phosphate and glauconite are typically present, with glauconite commonly filling intraparticle pores in large foraminifers. In the lower part (Unit VIIB), successions of turbidite sands show both upward-thinning/fining and upward-thickening/ coarsening trends; overall they coarsen up (Figs. 15 and 16).

Debris-flow and slump deposits are most common in the upper part of the unit. The debris-flow conglomerates contain a wide variety of clasts, including neritic limestone, in addition to folded slabs of chalk, mixed sandstone, and calcareous claystone. The matrix materials in the conglomerates show a wide range of compositions, including foraminiferal mixed mudstone, muddy foraminiferal quartzose mixed sandstone, and rare chalk and sandy mudstone. The slumped intervals are typically tightly folded and show sheared-out folds and clast break-up fabrics transitional into debris-flow deposits. Slumped intervals are thickest and most abundant in the middle of the unit (935-965 mbsf). Microfaulting occurs in several intervals, particularly at 915 to $955 \mathrm{mbsf}$, and is best developed in slumped intervals.

Hemipelagic sediments indicate a broad range of compositions from mixed mudstone to calcareous claystone to clayey calcareous chalk. In the upper part of the unit (Core 133-823C-12X), interbeds of white clayey calcareous chalk resemble those in Unit VI, the "zebra unit," indicating a gradational transition between the units. However, geochemical analyses indicate that mixed mudstone is the dominant hemipelagic sediment, with calcareous claystone at several intervals (Shipboard Scientific Party, 1991, p. 713).

Biostratigraphic age control is available for only the lower part of the unit (>967 mbsf). Five closely spaced biohorizons in the lower part of the hole indicate a greatly reduced average sedimentation rate $(16 \mathrm{~m} / \mathrm{m} . \mathrm{y}$ ) in the latest middle to early late Miocene (8.2-10.8 Ma).

Seismic data show significant variations in morphology and thickness of sequences, interpreted to represent Unit VII (Figs. 13 and 14). The contour maps for the horizons bounding sequence 11 indicate that these surfaces dip to the west in the opposite direction from all the higher reflectors (Figs. 14E and 14G). Isopachs for sequence 11 indicate small lobate "thickenings" near Site $823(\sim 2 \mathrm{~km}$ across; Fig. $14 \mathrm{H})$. Isopach maps for sequence 10 show a dramatic thinning eastward (Figs. 13 and 14F). This sedimentary wedge remained as a paleobathymetric high (Fig. 14C) onto which sequence 9 (Unit VI) onlapped. By the base of sequence 8 (upper Unit VI), the structural depression was filled with sediments so that an eastward slope was established (Figs. 13 and 14D).

\section{DEPOSITIONAL HISTORY}

Site 823 records the depositional history of the Queensland Trough from the mid-Miocene to the Holocene (Fig. 16). The composition and nature of turbidites, debris-flow and slump deposits, and hemipelagic sediments provide clues for interpreting the response of shelves and slopes adjacent to the Queensland Trough to the combined influences of tectonics, sedimentation, and fluctuations in eustatic sea level (Stow et al., 1985; Eberli, 1991). To interpret the succession of gravity deposits at Site 823 , all of these factors must be considered. Tectonic movements were a dominant control during the middle to late Miocene and may have continued into the Pliocene. Fluctuations in eustatic sea level (Haq et al., 1988; Wornardt and Vail, 1991) may be related to variations in sediment composition, particularly in the Pleistocene. Analysis of the gravity deposits of Site 823 yields considerable insights on the evolution of the Queensland Trough.

\section{Middle to Late Miocene Tectonism}

Middle to upper Miocene turbidites in the lower part of Unit VII are organized into an overall upward-coarsening succession that suggests deposition by prograding turbidite systems (Fig. 15; see Walker, 1978, 1984). These bedded turbidites have been interpreted to represent the continuous reflections in the lowermost part of sequence 10 , indicating that these sediments were deposited following a period of tectonic tilting and differential subsidence of the Queensland Trough (Figs. 2 and 13). Seismic data for the underlying sequence 11 show a series of lobate bodies that may represent small submarine fan lobes that extend eastward over an irregular bottom topography (Figs. 14G and 14H). Alternatively, these lobate thickenings and irregular westward-sloping bottom topography may be post-depositional deformational features related to later westwardsliding and compressional-buckling.

During the middle to late Miocene, active faulting and differential subsidence caused tectonic tilting of the seafloor beneath Site 823 (Figs. 2 and 13). The wedge-like body of sediment comprising sequence 10 has an unusual geometry, which is interpreted as a large submarine slide that moved along a westward-dipping detachment horizon within sequence 11 (Figs. 13 and 14). Sequence 10 correlates with the middle part of Unit VII (Figs. 2 and 16), which has an upward increase in debris-flow and slump deposits. Thus, sequence 10 probably represents a slide block and debris apron that accumulated in a structural depression at the base of faulted and tectonically tilted slopes (Figs. 2 and 13; Eberli, 1987, 1991). The structural depression adjacent to this postulated slide block was later filled by the slump and debris-flow deposits of uppermost Unit VII and Unit VI (seismic sequences 8 and 9; Figs. 14B-14D). 


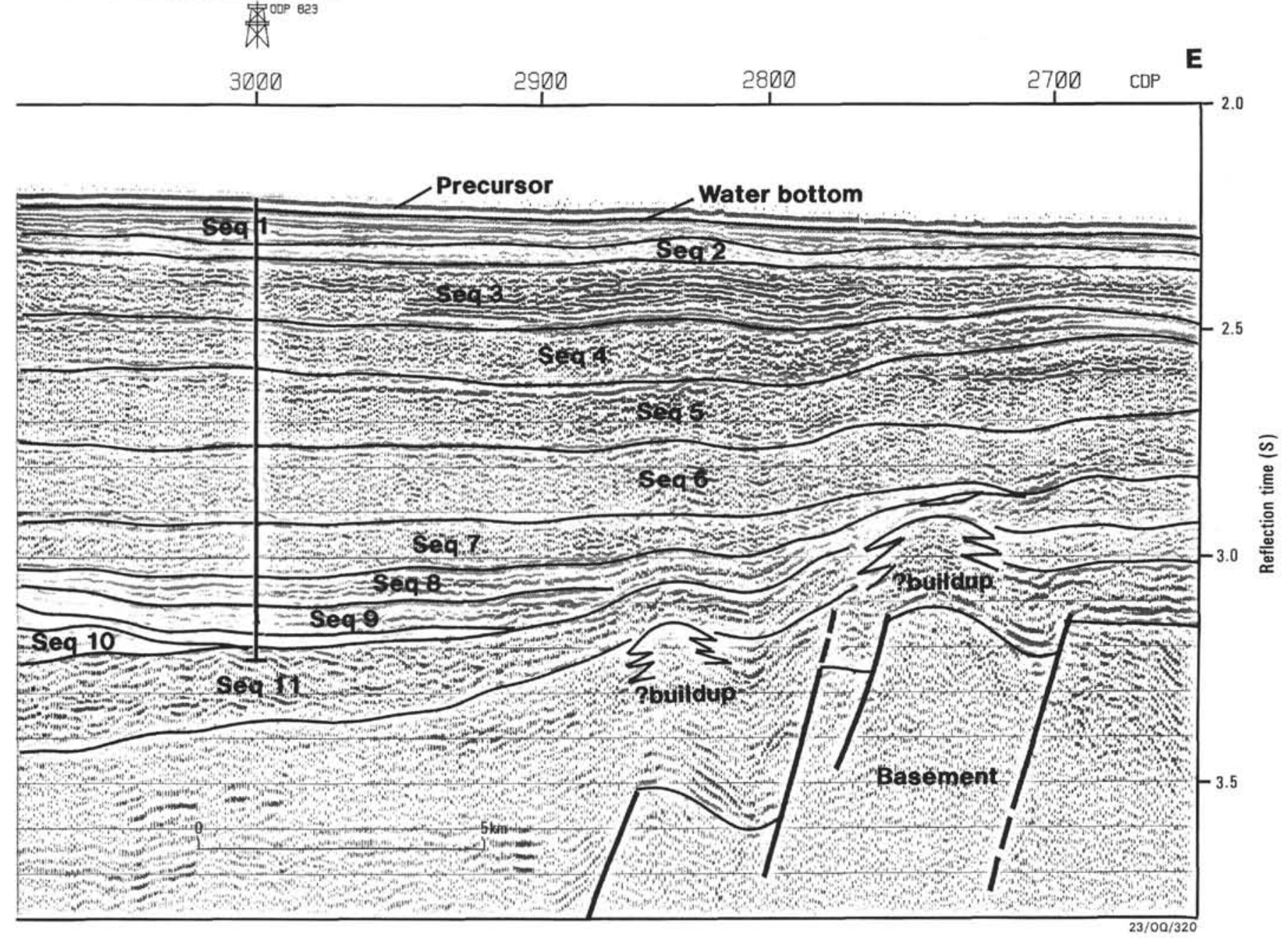

Sequence boundary

Fault

Figure 13. Seismic profile trends east-west across Site 823 and part of the Queensland Trough. Location of profile is shown in maps (Figs. 1 and 14A). Note evidence of tectonic tilting of sequence 11. Sequence 10 (middle to upper Miocene Unit VII) is thought to represent a major slide block and associated gravity deposits that moved down tectonically steepened slopes. Sequence 9 (Unit VI) fills the ponded depression adjacent to the slide block. All later sequences have an eastward-to-northeastward slope, similar to the present seafloor. Differential subsidence and associated small-scale faulting continue up into sequence 5 .

Unit VII is distinguished by the clasts of neritic limestone that occur in several beds of relatively coarse-grained mixed sandstone turbidites and debris-flow conglomerates. In addition, bioclasts and large foraminifers within turbidites were derived from neritic sources and include red algae, rhodoliths, and Lepidocyclina foraminifers that have reefal affinities (Fig. 16). The limestone clasts and neritic bioclasts either were derived from carbonate build-ups on either side of the Queensland Trough or were transported down the trough axis from more distant carbonate platforms south of Site 823. The abundance of terrigenous sediment (quartz, feldspar, and lithic fragments) in these mixed sandstones indicates derivation from the basement rocks of northeastern Australia, either from the mainland or from basement highs on the eastern side of the Queensland Trough (Fig. 2). The compositional and textural immaturity (presence of relatively angular feldspars and lithic fragments) and coarse grain size favor derivation from locally uplifted fault blocks that exposed basement rocks (Feary et al., this volume). In contrast, more mature, relatively rounded quartz (such as that in the higher units) was probably transported from sources in mainland Australia. Hemipelagic sediments are dominated by mixed mudstone and claystone with terrigenous mud, presumably derived from the Australia mainland. Ubiquitous pelagic foraminifers were reworked from slopes and increase in abundance upsection, with a concomitant decrease in other components.
Low sedimentation rates within the lower part of Unit VII (Fig. 12 and Table 2) may have favored formation of glauconite and phosphate redeposited in the mixed sandstone turbidites (Fig. 16). However, the mixed sandstone turbidites also contain relatively coarse-grained terrigenous sediment that indicate significant clastic influx, rather than the thin accumulations of mud expected in a condensed sequence. The more rapid rates of sedimentation seen in higher units resulted from major influx of terrigenous hemipelagic muds from the Australian continent, with admixtures of pelagic carbonate. The reason for the lower influx of terrigenous sediment during the middle to early late Miocene is unknown, but tectonic movements at this time may have preceded renewed uplift of terrigenous source areas, such as the Great Dividing Range of northeastern Australia (Belperio, 1983).

\section{Late Miocene Drowning of the Northeastern Australia Shelves}

The reduced supply of terrigenous and bioclastic sediments indicates that the shelves bounding the Queensland Trough were drowned during the late Miocene (see Schlager, 1980, 1981; Robertson and Bliefnick, 1983). Debris-flow conglomerates and turbidites in the lower part of Unit VI indicate continued slope instabilities. The absence of neritic limestone fragments above Unit VII indicates that 


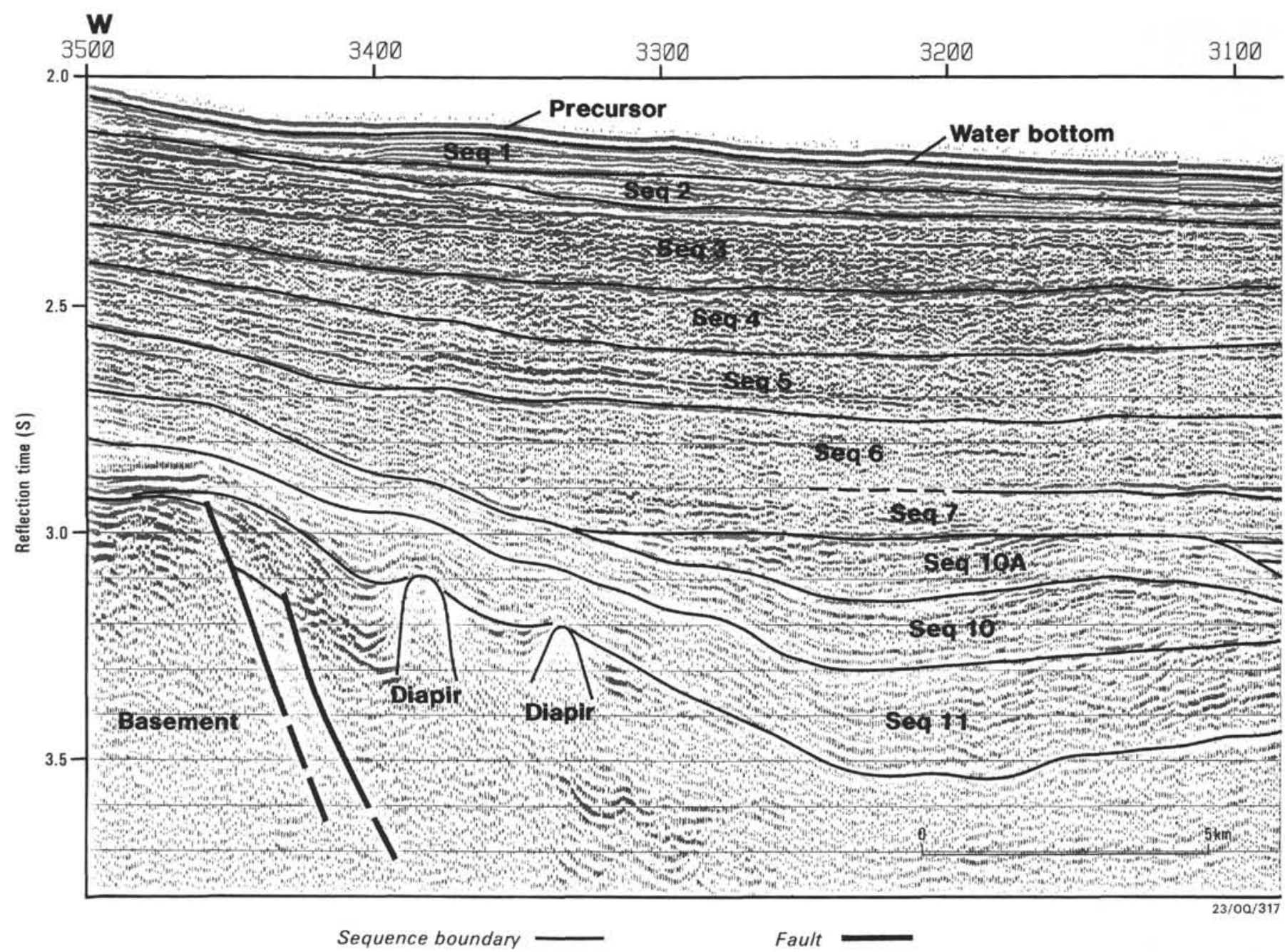

Figure 13 (continued).

drowned carbonate platforms were buried beneath blankets of hemipelagic sediments. The influx of terrigenous quartz in turbidites in the lower part of Unit VI ( $870 \mathrm{mbsf} / 7.1 \mathrm{Ma})$ diminished as drowning of the northeastern Australia shelf began. The estimated age of this drowning event is approximately 6.6 to $6.8 \mathrm{Ma}(830-850 \mathrm{mbsf})$, based on the last significant influx of red algae, bivalves, and large neritic foraminifers in turbidites (Fig. 16). The eustatic sea-level curve shows a highstand at this time (Haq et al., 1988). Thus, this drowning event may have resulted from tectonic subsidence, coupled with a eustatic highstand of sea level.

Following the drowning event, turbidites at the top of Unit VI consist primarily of reworked planktonic foraminifers, indicating that basement highs were blanketed by hemipelagic sediments. Interestingly, the decrease in neritic bioclasts and inferred platform drowning coincide with the reduced influx of debris-flow conglomerates in Unit VI, suggesting concomitant stabilization of the slopes bounding the Queensland Trough.

Turbidites at the top of Unit VI consist primarily of reworked planktonic foraminifers, indicating that basement highs were blanketed by hemipelagic sediment. Chalk is the dominant background sediment, indicating minimal terrigenous influx except in muddy and sandy turbidites. Unfortunately, the absence of age control in Unit VI requires us to interpolate the age of the drowning event between biohorizons in adjacent units, possibly resulting in errors in estimating age. The interpolated ages shown in Figure 16 asume a constant sedimentation rate of $87 \mathrm{~m} / \mathrm{m}$.y. (see discussion in Unit VI description and Fig. 12). However, the background sediments of Unit VI were dominated by pelagic carbonate ooze (now chalk), implying relatively low sedimentation rates, particularly for the upper part of Unit VI that contains fewer and thinner gravity deposits.

Independent evidence of this drowning event is provided by Katz and Miller (this volume). Benthic foraminifers indicate that Unit VII and the lower part of Unit VI were deposited in shallower water than the younger sediments at Site 823 , in middle bathyal $(600-1000 \mathrm{~m})$ rather than lower bathyal (1000-2000 m) depths. Although Katz and Miller (this volume) state that the precise position/timing of this change in water depth is uncertain, it probably lies within Unit VI in the interval between 767 and 879 mbsf (between 5.89 and $7.19 \mathrm{Ma}$ ). Our estimated age of 6.6 to $6.8 \mathrm{Ma}$ for the drowning, based on turbidite compositions, is more precise; however, all age estimates are limited by poor biostratigraphic control in Unit VI.

\section{Latest Miocene Influx of Terrigenous Mud}

Unit $\mathrm{V}$ is dominated by mixed mudstone and claystone, indicating significant influx of terrigenous mud in the latest Miocene (Messinian, 5.5-6.2 Ma). The general absence of turbidites and debris-flow deposits indicates slope stability, with little significant influx of coarse redeposited sediments. The abundance of slumps indicates that slope failures were mass movements involving large coherent blocks of material, rather than sediment gravity flows. Although the predominance of muds suggests that the northeastern Australian shelf was still 

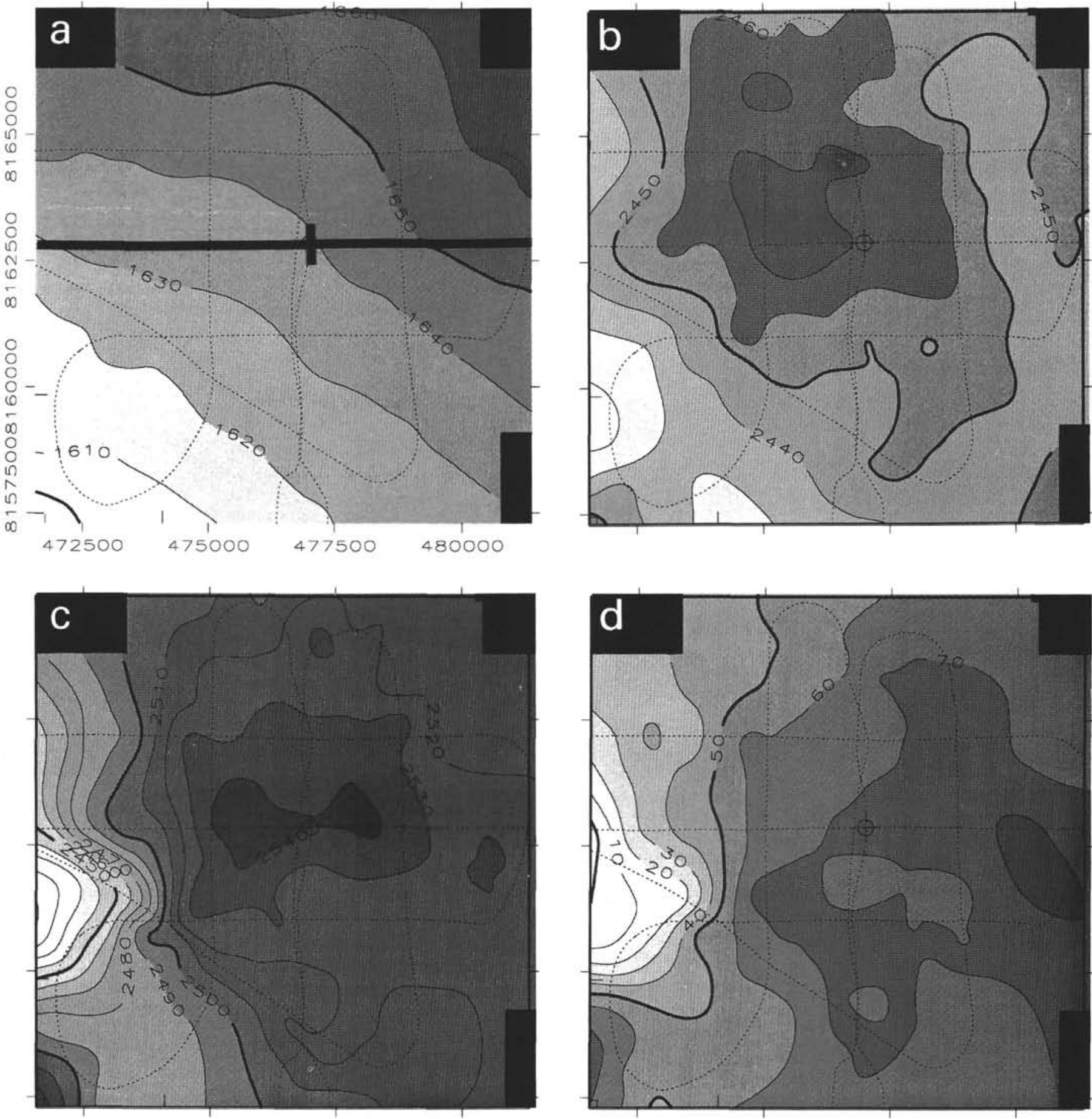

Figure 14. Maps derived from three-dimensional seismic data show the bathymetry of the seafloor (in m) near Site 823 and the calculated depths and thicknesses of seismic sequences 9, 10, and 11 (correspond to Units VI and VII). Larger-scale relationships are shown in seismic profiles (Figs. 2 and 13). A. Depth contour map showing the present-day seafloor that slopes to the northeast. The east-west line through Site 823 is the seismic line illustrated in Fig. 13. B. Depth contour map for the base of sequence 8 showing a generally northeasterly dipping surface, with some irregularities. Note that this slightly inclined, northeastward slope away from the northeastern Australia continental shelf is seen in seismic sequences 1 through 7 in the seismic profile (Fig. 13), with a geometry generally similar to that of the present seafloor. C. Depth contour map for the base of sequence 9 showing the eastern margin of a wedge-shaped paleobathymetric high formed by sequence 10. D. Isopach map showing the westward-thinning and onlapping of sequence 9 onto the paleobathymetric high formed by sequence 10 . E. Depth contour map for the base of sequence 10 showing a westward-dipping surface. F. Isopach map showing the dramatic westward-thickening of sequence 10, a wedge-shaped body interpreted as a giant slide block (see Fig. 13). G. Depth contour map showing the irregularities along the westward-dipping surface beneath sequence 11 . H. Isopach map showing the irregular lobate thickening of sequence 11 that may represent either submarine fan lobes or deformational features associated with tectonic tilting and westward-sliding of the sequence 10 slide block. 


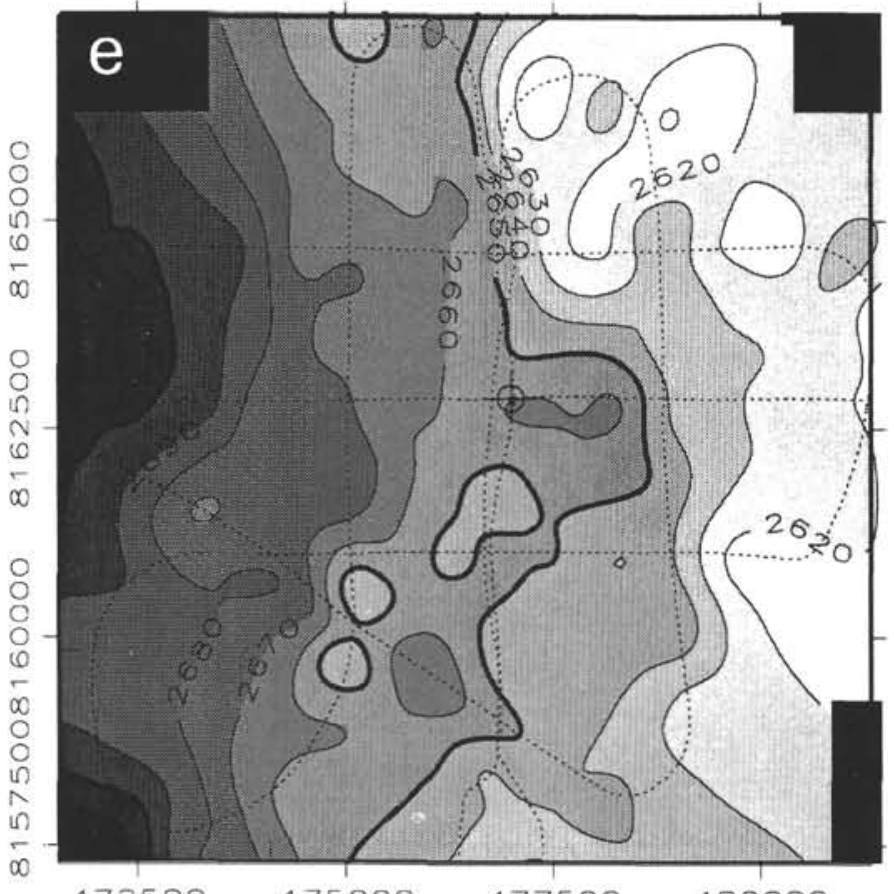

$472500 \quad 475000 \quad 477500 \quad 480000$

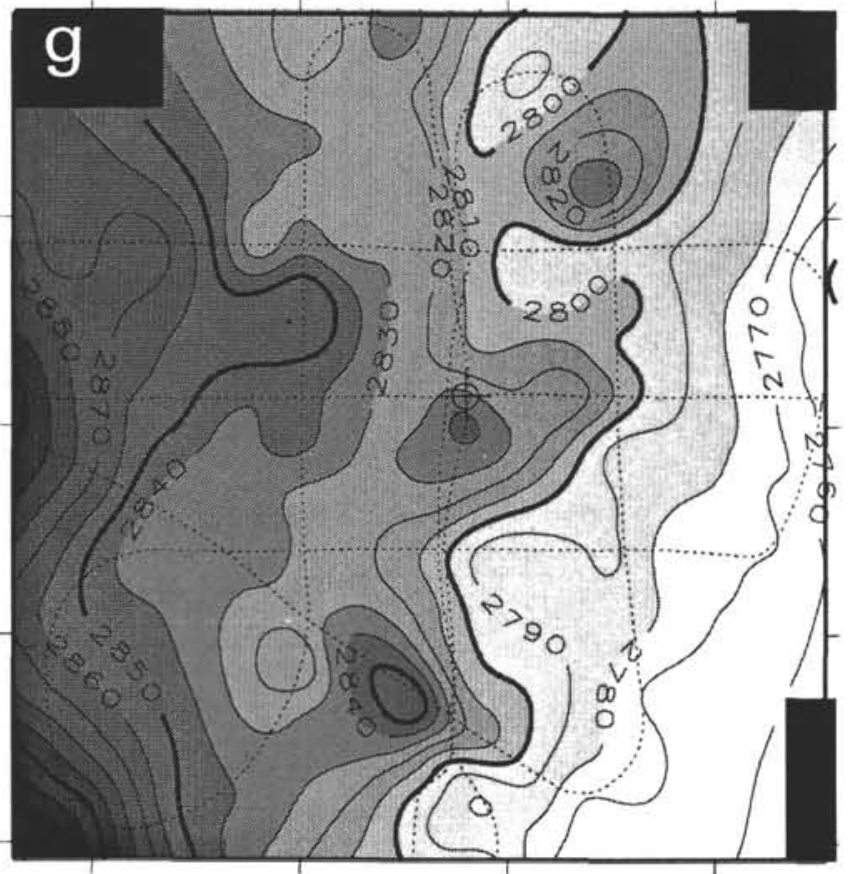

Figure 14 (continued)

drowned, significant amounts of terrigenous clay derived from mainland Australia were carried offshore and blanketed much of the Queensland Trough. Sedimentation rates were high and show a progressive increase $(115-151 \mathrm{~m} / \mathrm{m}$.y., averaging $121 \mathrm{~m} / \mathrm{m}$.y.). Quartz sand in turbidites precedes the influx of terrigenous mud, becoming common in the upper part of Unit VI (Figs. 10 and 11). Quartz is ubiquitous in the few turbidites of Unit V. Quartz increases in abundance (along with fewer bioclasts) toward the top of Unit $\mathrm{V}$ and the lower half of Unit IV (656-714 mbsf; Figs. 9, 10, and 16). The estimated age of this upper group of quartzose turbidites (5.2-5.6 Ma) may coincide with a major third-order sequence boundary and eustatic lowstand in the uppermost Messinian (Fig. 16; Haq et al., 1988;
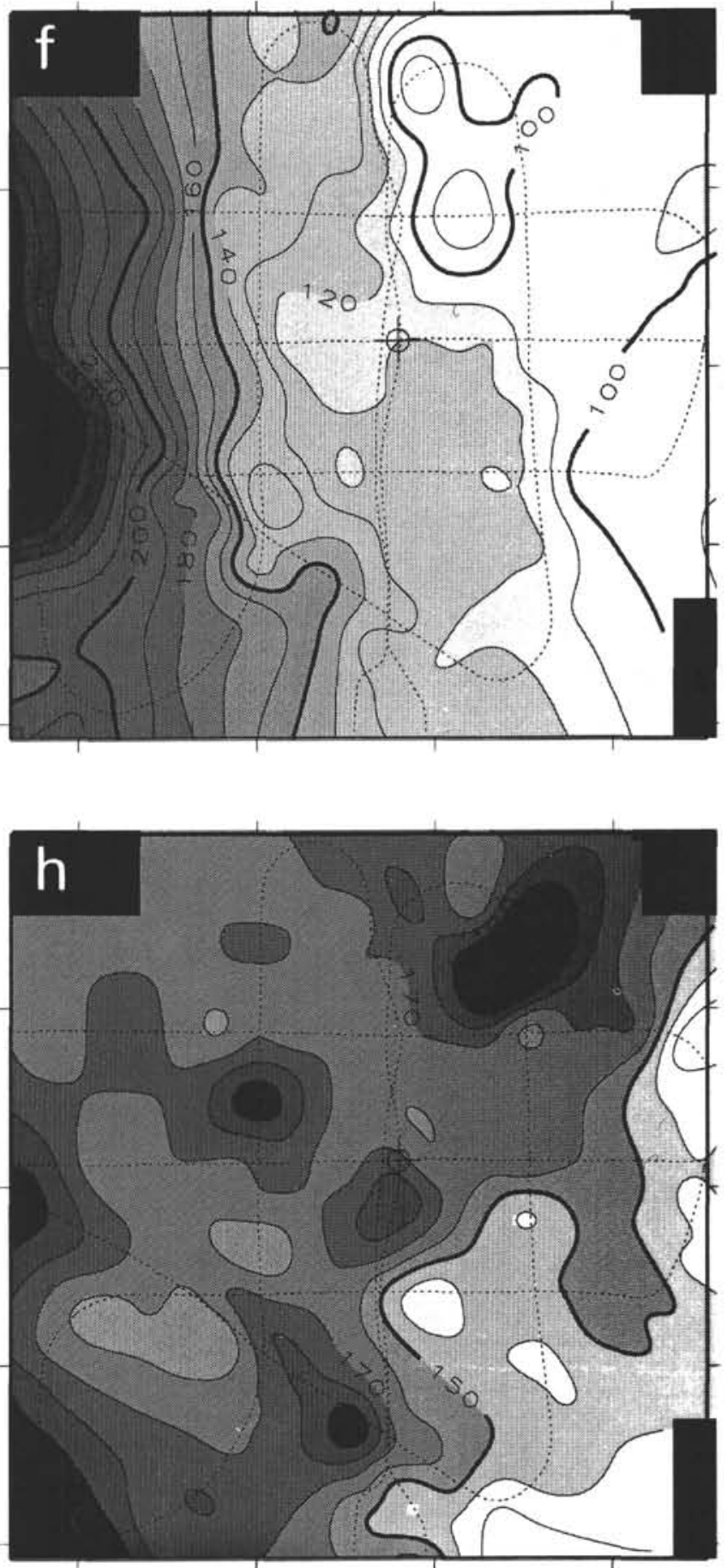

Wornardt and Vail, 1991). Unfortunately, age uncertainties cast some doubt on the depositional timing in Unit V.

\section{Early Pliocene Slumping and Debris Flows}

Unit IV formed during a time of continued stability, as indicated by the general paucity of debris-flow and turbidite deposits and the dominance of hemipelagic sediments (Figs. 9 and 16). Slumping was the major mechanism of the gravity transport, involving both hemipelagic clayey calcareous ooze (now chalk) and mixed mud (now mixed mudstone/marlstone) and periodically incorporating interbedded turbidites within slump blocks. Turbidites are slightly more 


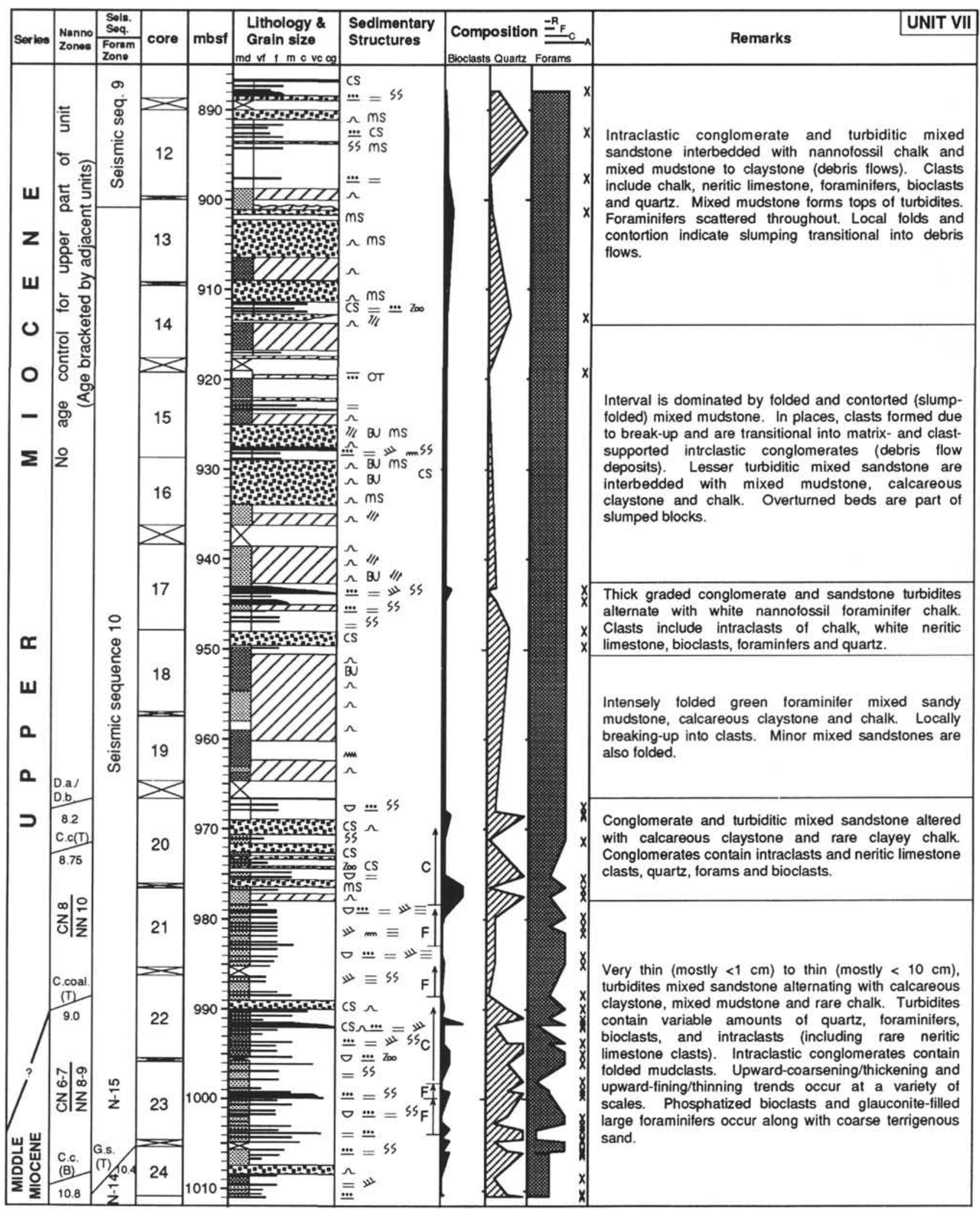

Figure 15. Generalized stratigraphic column for Unit VII. See Figure 4 for key to symbols. Note turbidites at base and debris flows and slumps at top. Also note the abundance of quartz and locally common bioclasts. Clasts of neritic limestone occur in gravity deposits throughout the unit. 
common than in Unit $\mathrm{V}$ and primarily are composed of reworked pelagic foraminifers, indicating that the northeastern Australia continental shelf remained drowned throughout the early Pliocene. One thick debris-flow conglomerate that initiated as a slump has an estimated age of $4.86 \mathrm{Ma}$.

Debris-flow deposits increase in abundance in Unit III, particularly in the upper part (Subunit IIIA, Fig. 8), possibly in response to a lowstand of sea level at 3.5 to $3.8 \mathrm{Ma}$ (Figs. 8 and 16). Alternatively, these slope failures may have resulted from renewed tectonic movements (differential subsiding) along faults that extend up to seismic sequence 5. Brittle faulting is evident as high as $395 \mathrm{mbsf}$ in Unit III, indicating that small-displacement tectonic movements possibly continued until as recently as $3.7 \mathrm{Ma}$. Strangely, variation in sedimentation rates within this interval shows no obvious correlation to either the abundance of gravity deposits or the eustatic curves (Figs. 8 and 16).

Following the succession of debris flows and slumps in Unit III, the lower part of Unit II is dominated by hemipelagic clayey calcareous chalk having rare, thin interbeds of turbiditic foraminiferal chalk, indicating relative slope stability (Figs. 7 and 16). These sediments were involved in slumping in a few intervals, indicating occasional small slope failures and mass movements. The 3.0 to $3.5 \mathrm{Ma}$ age of this interval indicates quiescence was restored in the early late Pliocene, during a transgression and highstand. Quartz is locally abundant, indicating either out-of-phase terrigenous influx or incorrect age determination.

\section{Late Pliocene Rejuvenation of the Northeastern Australia Shelf}

Abundant turbidites in Unit II show significant changes in composition, with influxes of quartz and bioclasts heralding the rejuvenation of the northeastern Australia shelf (Figs. 7, and 16). Inferred shallowing events may correspond with eustatic lowstands at 3.0 and $2.6 \mathrm{Ma}$, a time dominated by relatively low sea levels (Fig. 16).

Above and including Core $33 \mathrm{X}$ (308-259 mbsf), a progressive increase in turbidite abundance, bed thickness, and grain size indicates increasing supplies of reworked pelagic foraminifers to Site 823 from slope and/or drowned shelf sources. The estimated age of this increased turbidite influx coincides approximately with a third-order sequence boundary and a lowering of sea level at 3.0 Ma (Fig. 16; Wornardt and Vail, 1991).

The middle part of Unit II records a major change in patterns of sedimentation along the northeastern Australia margin. The influx of quartz and bioclastic sand in turbidites, in addition to increased abrasion and fragmentation of foraminifers, suggests a progressive lowering of sea level. The presence of terrigenous sand in turbidites indicates that the sediment was derived from the northeastern Australia mainland, rather than from the Queensland Plateau. Increased terrigenous influx also is indicated by relatively clay-rich hemipelagic sediments (Fig. 7). The abrasion of foraminifers attests reworking by waves or currents before transportation downslope by turbidity currents. The bioclastic grains are primarily bivalves and echinoderms and lesser ostracods that probably were reworked from neritic shelf sources along with neritic foraminifers. The age of this influx of mixed sandstone turbidites has been placed precisely at $2.6 \mathrm{Ma}$, which coincides with a fourth-order sequence boundary and a lowering of eustatic sea level (Wornardt and Vail, 1991). Before this time, turbidites containing pelagic foraminifers were reworked from the slope and/or drowned shelf. Counter-intuitively, sedimentation rates are relatively low between 1.8 and $2.6 \mathrm{Ma}$. Although the influx of turbidites containing bioclasts and quartz increased at this time, the reduced supply of debris-flow and slump deposits may have lowered the overall sedimentation rate.

The abundant debris-flow and slump deposits in the upper part of Unit II coincide with interbedded, relatively clay-rich, hemipelagic mixed mudstone and lesser calcareous claystone (Fig. 7). The association with mixed mudstone and calcareous claystone may suggest that these hemipelagic sediments were inherently incompetent and prone to generating slumps and debris flows. A debris-flow deposit at 161 to 167 mbsf contains some reworked material, as indicated by the reworked nannofossil Discoaster brouweri $(1.88 \mathrm{Ma})$ that is significantly older than its estimated age of $1.6 \mathrm{Ma}$. These older sediments were probably derived from erosion farther upslope, as indicated by a possible unconformity and erosional features of this age at Site 822 (Figs. 1 and 2; Shipboard Scientific Party, 1991, pp. 624 and 671). Turbidites containing bioclasts, quartz, and lesser foraminifers indicate continued influx of sediments from the northeastern Australia shelf. Slumped intervals typically contain turbidite beds and grade into debris-flow deposits with clast break-up fabrics, both of which suggest locally derived mass movements. The slump and debris-flow deposits do not show any obvious relationship to the eustatic curve (Fig. 16).

\section{Variable Pleistocene Sedimentation}

Unit I contains a variety of gravity deposits, including successions of turbidites and thick debris-flow and slump deposits (Figs. 6 and 16). Bioclastic grains and quartz continued to be transported into the Queensland Trough in turbidites, with a concomitant reduction in abundance of foraminifers (Figs. 6 and 16). Thus, the northeastern Australia continental shelf remained in relatively shallow neritic depths and was able to support a shelly fauna. No significant faults of this age are evident in seismic profiles (Figs. 2 and 13); thus, tectonics and associated seismicity were less important in triggering gravity flows here than in older units. However, the steep slopes bounding the Queensland Trough, which were inherited from previous tectonic movements, continued to generate a variety of gravity deposits.

Unit I and the uppermost part of Unit II are Pleistocene in age, which is widely recognized as a time of rapid glacioeustatic sea-level fluctuations. The age of Unit I is well constrained by closely spaced biohorizons. Although no single sedimentological variable can be consistently tied to sea-level fluctuations shown on the eustatic curves (Wornardt and Vail, 1991), some of the gravity deposits might be related to sea-level fluctuations, as explained below.

Continuing from the latest Pliocene into the early Pleistocene (as young as $1.4 \mathrm{Ma}$; Figs. 7 and 16), repeated slope failures generated debris flows and slumps. Then, a succession of turbidites formed at the transition between Units I and II (103-136 mbsf; approximate age, 1.23-1.38 Ma). The thickest turbidites are dated at 1.31 to $1.32 \mathrm{Ma}$ (114-116 mbsf) at the end of a lowstand in sea level that followed the 1.4 Ma sequence boundary (Wornardt and Vail, 1991). Younger turbidites show progressive decreases in bed thickness that might be related to a subsequent transgression. Alternatively, the turbidites may represent the final waning of the larger Pliocene-Pleistocene slope failures.

Later slump and debris-flow deposits in the middle of Unit I have an estimated age range of 0.58 to $1.13 \mathrm{Ma}$, a time of numerous small-scale fluctuations in sea level (Figs. 6 and 16). Because these thick debris-flow and slump deposits are event deposits and might have occurred at random intervals, it is difficult to determine accurately the precise age of each slope failure event. However, it is interesting that these slumps and debris flows occurred during a time of initiation of the Pleistocene high-frequency glacioeustatic sea-level fluctuations. Major decreases in sea level at this time are thought to be equivalent in magnitude to the most recent decline in glacioeustatic sea level (Wornardt and Vail, 1991) and may have been important in generating mass flows.

Thick turbidites in the upper part of Unit I are most abundant at 35 to $49 \mathrm{mbsf}$ and have an estimated age range of 0.48 to $0.55 \mathrm{Ma}$ (Figs. 6 and 16). An upward-thickening/coarsening sequence between 36 and $40 \mathrm{mbsf}(4.9-0.51 \mathrm{Ma})$ is particularly well developed and may be related to the 0.5 Ma sequence boundary. However, this interval apparently corresponds to the glacial isotopic stage 14 , which is a eustatic lowstand dated at $\sim 0.50$ to $0.54 \mathrm{Ma}$, indicating slight problems in age estimates (D. Kroon, written comm., 1992; see Shackleton 


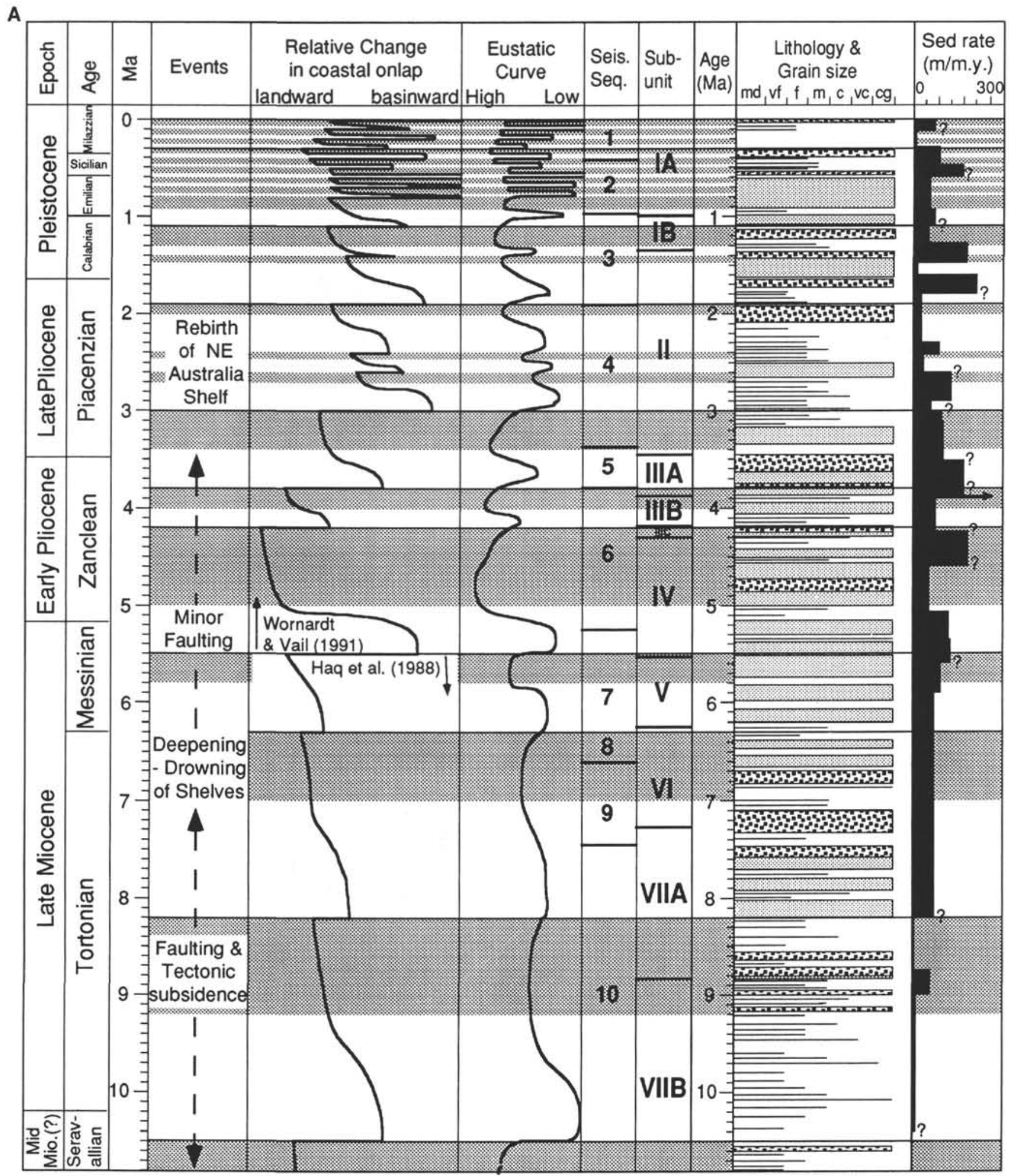

Figure 16. A. Chronostratigraphy of different units at Site 823 and generalized age distribution of different gravity-flow deposits are compared with eustatic onlap and sea-level curves for the middle Miocene to Holocene. The eustatic curves are from Wornardt and Vail (1991; between 6.0 Ma and present) and Haq et al. (1988; between 10.8 and 6.0 Ma). Horizontal lines are third-order sequence boundaries and shaded areas represent highstand system tracts (Wornardt and Vail, 1991 ; Haq et al., 1988). Major events influencing sedimentation in the Queensland Trough are also indicated. See Figure 4 for key to symbols used in lithologic column. Age data and sedimentation rates were taken from Tables 2 and 3. Note the absence of precise age control before 6 Ma and queries where biohorizons may have been reworked in gravity deposits. B. Abundance of different grains vs. age. Horizontal lines represent third-order sequence boundaries and the shaded pattern represents highstand system tracts (extending from Fig. 16A). Note increased abundance of bioclasts after 2.6 Ma. 
MIOCENE TO PLEISTOCENE TURBIDITES

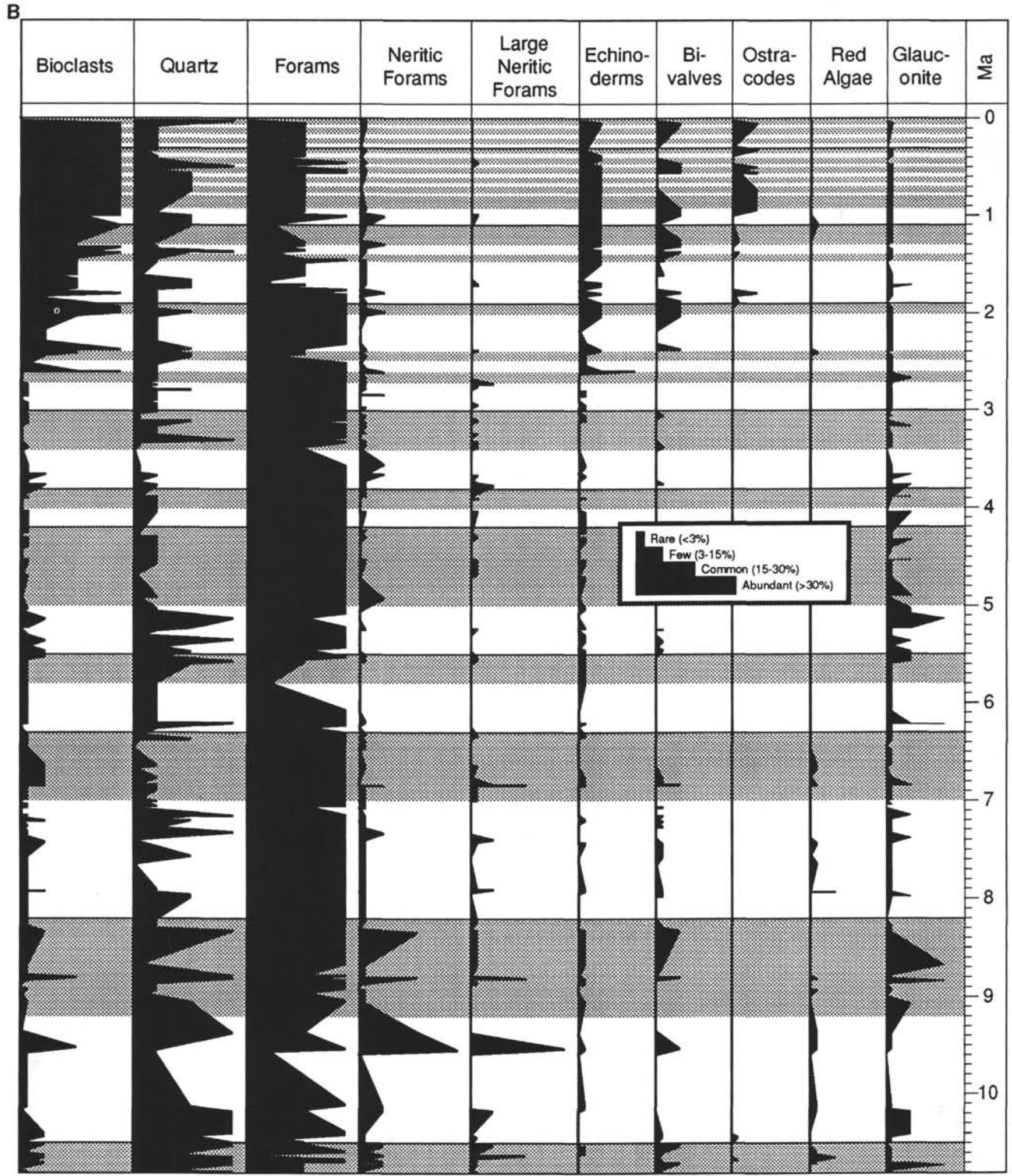

Figure 16 (continued). 
and Opdyke, 1976). The increased abundance of quartz in turbidite samples at 34 and $37 \mathrm{mbsf}(0.48$ and $0.49 \mathrm{Ma})$ indicates an influx of terrigenous sediments during a eustatic lowstand (possibly the $5.0 \mathrm{Ma}$ sequence boundary of Wornardt and Vail, 1991). Perhaps sea level was lowered sufficiently for terrigenous and bioclastic sediments to be transported across the shelf and down the slope as turbidites, but not low enough to trigger major slumps and slides. A thick debris-flow deposit at 16.1 to $24.3 \mathrm{mbsf}$ is estimated to be $0.4 \mathrm{Ma}$ in age, coinciding with another sequence boundary and eustatic lowstand (Wornardt and Vail, 1991).

Younger sediments are dominated by hemipelagic clayey calcareous ooze and mixed mud, with rare, very thin turbidites having no obvious relationship to the latest Pleistocene fluctuations in sea level. However, an unusual debris-flow deposit (at 1.25-1.85 mbsf) has an estimated age of $0.020 \mathrm{Ma}$ and includes a variety of coarse terrigenous sediments, neritic bioclasts (including Halimeda), and mud clasts eroded from older $(\sim 0.3 \mathrm{Ma})$ slope sediments. A lowstand of sea level during the most recent glacial epoch may have permitted coarse terrigenous sediments along with neritic bioclasts to be transported across the emergent northeastern Australia shelf. These mixed sediments spilled over the shelf margin, moved downslope as a debris flow that eroded mud clasts from the channel walls, and were deposited at Site 823 .

\section{CONTROLS ON THE NATURE OF GRAVITY DEPOSITS}

What caused these slope failures and what determines the mechanisms of transport and deposition? Tectonics determines the basin configuration and differential subsidence controls slope steepness and accommodation space available for sediment (Stow et al., 1985). Seismicity associated with tectonic movements can cause liquefaction of unconsolidated sediments and result in slope failures (Einsele, 1989, 1991). Tectonic uplift of sediment source areas play a secondary role by influencing sedimentation rates and sediment compositions (Stow et al., 1985). Slope failures may also naturally result from sediments that accumulate on preexisting slopes until gravitational instabilities exceed their shear strength (Einsele, 1989, 1991; Stow and Piper, 1984; Stanley, 1985). The composition of sediments determines their shear strength, the nature of slope failures, and resultant gravity deposits (Einsele, 1989, 1991). Fluctuations in eustatic sea level influence water depth, energy conditions, and sediment supply to the shelf edge and slope (Eberli, 1991). Gravity deposits of the Queensland Trough (Site 823) were generated by a combination of these factors. Tectonics was particularly important during the Miocene, as variations in sedimentation rates and composition affected gravity deposits throughout the succession, and relative and eustatic sea-level fluctuations were also important.

\section{Tectonics}

The Queensland Trough is a marginal basin that initially developed as a result of extensional tectonics and rifting during the Late Cretaceous and Tertiary (Symonds et al., 1983; Davies et al., 1989). Tectonic movements were important in establishing the basin architecture by creating steep slopes along the margins of the Queensland Trough. Tectonically steepened slopes set the stage for the generation of thousands of gravity deposits. The Queensland Trough seismic profile (Fig. 13) is remarkably similar to that of the Miocene-Pliocene Tyrryhenian slope basins east of Sardinia (Stanley, 1985, p. 400); both areas are dominated by redeposited muds. The Queensland Trough effectively separates the northeastern Australia mainland from the Queensland Plateau, an isolated carbonate platform that flourished through much of the Miocene (Davies et al., 1989). Smaller structural depressions (slope basins) in the late Miocene may have similarly captured terrigenous sediments shed from the Australian mainland. During the late Miocene to Pliocene, tectonic readjustments led to reactivation of faults in the Queensland Trough and to destabilization of its slopes. A component of compression in the late Miocene fault movements led Symonds et al. (1983) to interpret them as convergent/left-lateral wrench faults. Structures inherited from the previous extensional tectonism apparently were reactivated in an intraplate compressional regime, possibly related to convergence along the northern and eastern margins of the Australian Plate (see Cloetingh, 1988).

Faulting, differential subsidence, and tilting caused slopes bounding the Queensland Trough to become unstable. Westward-tilting and associated seismicity possibly caused a huge gravitational slide block to become detached from the eastern fault scarps and to slide toward the subsiding axis of the Queensland Trough. Debris-flow and slump deposits in Unit VII were generated at 8.6 to 9.2 Ma, despite a eustatic highstand at this time (Figs. 15 and 16). Some of these slope failures may have been triggered by associated seismicity (Mutti et al., 1984; Einsele, 1991). Interestingly, small-scale fault offsets (microfaults) are most common in Unit VII, particularly in slump blocks, providing independent evidence of faulting at the basin margins (Eberli, 1987, 1991). Basement rocks were uplifted and exposed to submarine erosion, as recorded by immature sands (relatively coarse-grained, angular and unweathered feldspars and lithic fragments). Some of these basement highs may have been capped by carbonate build-ups, as fragments of neritic limestone suggest (Cook and Mullins, 1983; Cook et al. 1972).

A structural depression adjacent to the slide block became a small ponded basin that was rapidly filled with gravity deposits and hemipelagic sediments (dominated by calcareous chalk that was isolated from mixing with terrigenous detritus). Interestingly, the increased sedimentation rates and the influx of terrigenous mud from the Australian continent post-date the tectonism in the Queensland Trough, perhaps heralding uplift of sediment source areas on the Australian mainland. Later tectonic movements in the Queensland Trough were relatively minor, as indicated by the absence of significant tilting of sequence 9 and of younger deposits. However, differential subsidence resulted in small-scale movements along preexisting faults that extend as high as seismic sequence 5 (Unit III). The highest occurrence of microfaults is in Unit III at 395 mbsf $(\sim 3.7 \mathrm{Ma})$, which provides independent evidence of the minimum age of fault movements. Alternatively, subsidence and microfaulting may have resulted from differential compaction of heterogeneous basinal sediments.

The late Miocene ( 6.6-6.8 Ma) pulse of tectonic subsidence, together with eustatic highstands, led to the drowning of the Queensland Plateau carbonate platform (see Davies et al., 1989; Katz and Miller, this volume; Schlager, 1981). Subsequently, the predominance of pelagic foraminifers in turbidites from Site 823 indicates that the northeastern Australia shelf remained drowned until a eustatic lowstand at 2.6 Ma permitted bioclastic and quartzose sediments again to be produced on the northeastern Australia continental shelf and supplied to the Queensland Trough (see below).

\section{Sedimentological Controls}

What do the composition and nature of turbidites, hemipelagic, and other gravity deposits imply about the nature of slope failures and sedimentation on adjacent shelves? The composition of sediments can provide valuable clues about sediment source areas, particularly the shelves and slope bounding the Queensland Trough. The mechanical behavior of different types of sediment are important components for determining their proclivity to slope failure and the type of gravity deposit generated by downslope movement (Stanley, 1985; Einsele, 1989, 1991).

\section{Turbidite Sands}

A supply of sand-sized sediment is necessary for sandy turbidites to develop. The Queensland Trough has three sources of sand that are related to specific sources of sediment: (1) terrigenous sediment from 
the Australian mainland or from local late Miocene basement highs adjacent to the trough, (2) planktonic foraminifers that were reworked from the slopes bounding the adjacent trough or swept off drowned shelves, and (3) neritic carbonate sediment, primarily bioclasts that originally inhabited shallow-marine shelves. Limestone fragments were derived from carbonate platforms before their burial beneath hemipelagic sediments during the late Miocene. Other common sand grains include glauconite and phosphate that formed as authigenic minerals on the seafloor. By examining the composition of turbidites, inferences can be made about the nature of sedimentation on the adjacent shelves, which serve as the source of turbidite sands (Rusnak and Nesteroff, 1964; Scholle, 1971; Cook and Taylor, 1977; Davies, 1977; Schlager, 1980; Thiede, 1981; Premoli Silva and Brusa, 1981; Robertson and Bliefnick, 1983; Watts and Garrison, 1986; Schlanger and Premoli Silva, 1986; Eberli, 1987, 1991; Reijmer, 1988, 1991; Haak and Schlager, 1989; Dolan, 1989; Yose and Heller, 1989; Watts and Blome, 1990; Everts, 1991).

Although small amounts of wind-blown quartz silt are ubiquitous, quartz sand indicates influxes of terrigenous sediments, typically during lowstands of eustatic (or relative) sea level (Vail et al., 1977; Shanmugam and Moiola, 1982; see below). Terrigenous sand (typically well-rounded quartz) and mud were derived mostly from the adjacent Australian mainland. Unusually coarse and compositionally immature sands (slightly weathered feldspars and lithic fragments) were probably derived from local basement highs that were uplifted during times of active faulting (such as the late Miocene uplifts shown in Figs. 2 and 14; see Feary et al., this volume).

Turbidites composed almost entirely of planktonic foraminifers indicate drowned shelves, where the only sand-sized sediments available for transport were planktonic foraminifers (Scholle, 1971). Pelagic sediments raining down out of the water column apparently accumulated on the slopes of the Queensland Trough until gravitational instabilities caused slope failure and the development of turbidity currents. This process would be similar to snow avalanches that occur on steep mountain slopes, with the foraminifers and other hemipelagic sediments being the pelagic "snow." At Site 823, almost all the turbidites (including mixed sandstones) contain an admixture of planktonic foraminifers, indicating that these grains were entrained as the turbidity currents moved down slopes blanketed by hemipelagic sediments.

Bioclastic sands provide even more information about their source (Reijmer et al., 1988; Haak and Schlager, 1989). Some bioclasts (such as red algae) required a stable substrate within the photic zone and typically indicate a carbonate platform source. Rare rhodoliths in Unit VII probably were derived from a reef (? Martin, pers. comm., 1991). Bivalves, echinoderms, ostracodes, and neritic foraminifers are ubiquitous along the northeastern Australia shelf (Marshall and Davis, 1978). The influx of bioclastic sands at $\sim 2.6 \mathrm{Ma}$ indicates re-establishment of neritic conditions on the northeastern Australia shelf.

\section{Hemipelagic Muds}

Hemipelagic muds also show variations in composition that are related to different sources of suspended mud-sized sediment. Terrigenous clays and silt presumably were derived from the Australian mainland and transported as suspended sediment offshore (Belperio, 1983; Stow and Piper, 1984; Stanley, 1985). Wind-blown silt and clay also were derived mostly from the Australian mainland. Pelagic ooze/chalk is composed of coccoliths and planktonic foraminifers that lived in the water column and fell to the seafloor as perennial sediments (Scholle, 1983). Periplatform ooze is fine-grained aragonitic mud that is derived from neritic carbonate platform sources (Droxler et al., 1983; Boardman and Neumann, 1984). Because this fine-grained aragonite typically is lost with diagenesis, periplatform ooze is difficult to distinguish in older deposits.

Much (perhaps two-thirds!) of the muddy sediments in structural basins bounded by muddy slopes probably was redeposited by mud flows and dilute muddy turbidites (Stanley, 1985). Thick intervals of uniform mud (unifites of Stanley, 1985) lacking sedimentary structures may represent redeposited muds and are difficult to distinguish from homogeneous bioturbated muds deposited as hemipelagic "rain" (Hesse, 1975; Stow and Piper, 1984).

Hemipelagic sediments at Site 823 are mixtures of the above components. The most common hemipelagic sediment is mixed mudstone (40\%-60\% carbonate), indicating combined pelagic and terrigenous sediment sources (Shipboard Scientific Party, 1991, p. 712 -713). Clays are the dominant terrigenous component, with quartz silt generally being less than $10 \%$. Hemipelagic sediments in Unit VII are dominated by calcareous claystone and mixed mudstone with associated quartz sand, which indicate a predominantly terrigenous source. Unit VI contains interbeds of relatively pure calcareous chalk, which suggests low pelagic sedimentation rates and/or partial seclusion from terrigenous influx. Alternatively, these calcareous sediments may have been reworked off the Queensland Plateau, an isolated drowned platform separated from terrigenous detritus (Davies, 1989; Shipboard Scientific Party, 1991). Terrigenous muds in Unit VI occur as turbidites derived from the northeastern Australian continental shelf. The influx of terrigenous mud reaches a maximum in Unit V with increased sedimentation rates, implying possible uplift of terrigenous source areas on the Australian mainland. Alternatively, more proximal structural depressions may have captured most of the terrigenous sediments, and the influx of terrigenous muds at Site 823 is a consequence of progradation and filling of slope basins.

Another possibility is that the influx of terrigenous mud resulted from climatic changes related to the northward drift of the Australian Plate. Units higher in the section show alternations between clayey calcareous ooze/chalk and mixed mudstone/mud that are not well understood. Although calcite is the dominant carbonate component, aragonite occurs in the upper $250 \mathrm{mbsf}$ of Units I and II (Shipboard Scientific Party, 1991, p. 714). The supply of periplatform aragonite generally coincides with the influx of bioclasts in turbidites and increasing contribution of periplatform sediment after $2.67 \mathrm{Ma}$. However, the contribution of aragonitic bioclasts (rather than periplatform ooze) to this geochemical signature is unknown.

\section{Debris-flow and Slump Deposits}

Many debris flows originated as slumps, as indicated by folded intraclasts and evidence of internal shearing of plastic muddy matrix material (Pls. 3 and 4). Intraclasts are typically composed of calcareous claystone/clay and clayey calcareous chalk/ooze. The shear strength of mixed muds is related to their carbonate content (Kenter and Schlager, 1989), with pure carbonates being more competent than marly/mixed muds. Debris-flow deposits at Site 823 most commonly have matrix material composed of mixed mudstone. Within the intraclastic debris flows, clasts of clayey calcareous (nannofossil-foraminifer) ooze typically were folded plastically, whereas cohesive calcareous claystone broke into tabular to rounded clasts (PIs. 3 and 4). Clasts of neritic limestone are confined to Unit VII, indicating exposure and erosion of carbonate platforms during the late Miocene. Clayey calcareous ooze (now chalk) appears to be more competent and may have moved downslope as coherent slump blocks (Einsele, 1991). Cohesive calcareous claystone, such as that in Unit V, also appears to have moved downslope as slump blocks. Thus, some intervals that are dominated by debris-flow and associated slump deposits, such as the upper parts of Units II and III, may have been inherently unstable because of their incompetent mixed mud composition. With downslope movements, mixed muds tended to evolve into debris flows, whereas clay-rich or carbonate-rich muds were more coherent and remained as intact slump blocks. Slide deposits (see Einsele, 1991) could not be distinguished in narrow cores because they lacked diagnostic sedimentary structures (e.g., inclined bedding, folding, and overturned beds that were used to recognize slump deposits). Homogeneous mud-flow deposits would be indistinguishable from hemipelagic muds, lacking the clasts that characterize debris-flow deposits. 


\section{Submarine Fan Variables}

Facies models have been widely used to interpret gravity deposits as different parts of submarine fans (e.g., Mutti and Ricci-Lucchi, 1978; Walker, 1978, 1984). Can gravity deposits at Site 823 be explained as a consequence of migration of submarine fan facies through time? How can such facies variables be distinguished from the influences of tectonics, sedimentation, and eustasy (see below)? Application of submarine fan models without consideration of other factors might lead to erroneous interpretations. Successions of unchannellized turbidites, such as those in Unit II, might be interpreted as submarine fan lobe deposits (Facies C of Mutti and Ricci-Lucchi, 1978), particularly where organized into upward-thickening/coarsening successions. The debris-flow and slump deposits may be interpreted as inner-fan channel and slope deposits (Facies A and F of Mutti and Ricci-Lucchi, 1978). Thin turbidites in intervals dominated by hemipelagic muds then might be considered either basinal deposits or interchannel areas on the upper fan or slope (Facies D, E, and G of Mutti and Ricci-Lucchi, 1978).

However, submarine fan models probably may not apply to basins in tectonically active regions, particularly narrow, structurally controlled basins that might promote longitudinal transport of sediment gravity flows (Walker, 1984; Hsü et al., 1977; Eberli, 1987, 1991). Queensland Trough is a narrow basin confined to a structural depression, with relatively steep slopes along its margins (Stanley, 1985). Because the shelf was drowned for much of its history, coarse terrigenous sediment was not supplied at point sources (Mullins and Cook, 1986). Instead, huge volumes of sediments deposited in the Queensland Trough were reworked from unstable slopes. Slopes that were oversteepened by tectonic tilting and/or differential subsidence were particularly susceptible to failure. Thus, the basin geometry, particularly its steep marginal slopes, was instrumental in controlling facies distribution.

Strong continuous reflectors traceable across the entire Queensland Trough seismic profile correlate with intervals that contain well-bedded turbidites and hemipelagic sediments (Figs. 3 and 13). The intervening debris-flow and slump deposits correlate with thick intervals that generally lack reflectors. This would indicate that the different types of gravity deposits are widespread and formed at specific times during the history of the margin. It is unclear if any point source fans existed in the Queensland Trough. Instead, thick, laterally continuous successions of gravity deposits and interbedded hemipelagic sediments blanketed the entire basin floor.

\section{Eustatic Fluctuations in Sea Level}

The excellent age control in Units I to V provides an opportunity to compare the age distribution and the nature of different gravity deposits vs. eustatic and onlap curves (Fig. 16; Haq et al., 1988; Wornardt and Vail, 1991). Tectonics was important in the Miocene to Pliocene period of the Queensland Trough and no doubt triggered many of the sediment gravity flows. Nonetheless, in some cases, eustatic highstands or lowstands correspond with major events affecting the Queensland Trough and its adjacent shelves, particularly the drowning and rejuvenation of shelves bounding the trough.

The drowning of the northeastern Australia shelf and Queensland Plateau generally coincides with the major second-order highstand that culminated at 4.2 Ma. Although tectonics was most important, the third-order highstand between 6.3 and $7.0 \mathrm{Ma}$ coincides with this deepening drowning event (Fig. 16). During this prolonged drowning from the late Miocene to middle late Pliocene, eustatic fluctuations had a limited effect. Upper Miocene to lower Pliocene Units IV and V are dominated by clay-rich hemipelagic sediments that were prone to slumping. The few turbidites that were generated at this time consisted of foraminiferal ooze reworked from hemipelagic slope sediments.

The rejuvenation of the northeastern Australia continental shelf coincides with fourth-order lowstands at the 2.6- and 2.42-Ma se- quence boundaries (Fig. 16; Wornardt and Vail, 1991). Major changes in turbidite compositions indicate that the previously drowned shelf was rejuvenated after shallowing to neritic depths. With the initial shallowing, planktonic foraminifers were abraded and washed downslope as turbidites, along with increasing amounts of bioclasts and terrigenous sands. Increases in echinoderm and bivalve fragments were followed by an influx of ostracodes (Fig. 16). From this point onward, the northeastern Australia shelf remained shallow enough to permit continued influx of terrigenous sands and the production and redeposition of neritic carbonate bioclasts.

Unfortunately, no single sedimentological variable is tied consistently to sea-level fluctuations shown in the eustatic curves (Fig. 16; Wornardt and Vail, 1991). The absence of precise biostratigraphic age control in Units VI and VII makes it difficult to relate this succession to eustatic curves, particularly with the overwhelming influence of tectonism in these middle to upper Miocene deposits. Some of the lack of correlation with eustatic sea-level fluctuations might stem from uncertainties in age determinations that resulted from possible reworking of microfossils (biohorizon indicators). In addition, the age calculations of individual deposits also may be skewed by nonlinear sedimentation rates associated with rapid influx of thick gravity (event) deposits. Because most Site 823 sediments are mixtures derived from terrigenous, carbonate platform, and pelagic sources; the absence of direct correlations may result from different responses of different sedimentary systems to eustatic sea-level fluctuations.

Smaller-scale fluctuations in sea level are difficult to distinguish, although selected gravity deposits and turbidite compositions may coincide with specific eustatic lowstands or highstands shown in Figure 16. The influx of bioclasts and quartz is the best indicator, generally corresponding with eustatic lowstands. Planktonic foraminifers are most abundant during relative highstands and times of platform drowning. However, exceptions are the rule and no single sedimentologic variable consistently correlates with the eustatic signal.

Tectonics appears to have been the dominant control on gravity deposition until the latest Miocene. In the latest Messinian (5.2-5.7 Ma), an influx of quartz and bioclasts in turbidites and an increase in sedimentation rates generally correspond with a lowstand in sea level (Fig. 16). However, the first influx of quartz at 5.7 Ma precedes the $5.5-\mathrm{Ma}$ sequence boundary, possibly indicating reworking of the 5.6-Ma biohorizon in a slump deposit. Furthermore, the general absence of turbidites in Unit IV implies that the influence of this eustatic lowstand was minimal (Fig. 9). The lowstand shown for 4.0 to $4.2 \mathrm{Ma}$ apparently was not of sufficient magnitude to affect gravity sedimentation (Figs. 8 and 16).

A lowstand in sea level at 3.8 Ma may have been related to the thick succession of alternating debris-flow and slump deposits that comprise Subunit IIIA. However, these thick gravity deposits range in age between 3.88 and $3.44 \mathrm{Ma}$, suggesting that a lowstand may have caused the initial slope failures, but was not the only control. The debris-flow deposits also may have been related to compositional weaknesses of mixed muds (marly sediments, see above). The lowest part of Unit II consists of hemipelagic clayey calcareous chalk having rare turbidites and slumped intervals that were deposited during the ensuing transgression and highstand (3.1-3.4 Ma).

During the early late Pliocene, a progressive increase in turbidite abundance, bed thickness, and grain size indicates increasing supplies of reworked pelagic foraminifers to Site 823 from slope and/or drowned shelf sources. The estimated age of this increased turbidite influx coincides approximately with a third-order sequence boundary and a lowering of sea level at 3.0 Ma (Fig. 16; Wornardt and Vail, 1991). The lowstands at 2.6 and 2.4 Ma coincide with rejuvenation of neritic shelf sedimentation, as indicated by quartz and bioclasts in turbidites.

Sequence boundaries and associated lowstands between 1.9 and 1.3 Ma may be represented by turbidites and lesser debris-flow deposits of uppermost Unit II and lowermost Unit I. However, similar debris-flow and slump deposits extend back to $2.1 \mathrm{Ma}$, suggesting that other variables were the dominant control. The ensuing transgres- 
sion and highstand at 1.3 Ma are associated with an interval dominated by hemipelagic sediments having rare, very thin turbidites. Alternatively, the turbidites might represent the final waning of the larger Pliocene-Pleistocene slope failures.

Later slump and debris-flow deposits in the middle of Unit I have an estimated age range of 0.58 to $1.13 \mathrm{Ma}$, a time of numerous small-scale fluctuations in sea level (Figs. 6 and 16). Because these thick debris-flow and slump deposits are event deposits and may have occurred at random intervals, it is difficult to determine accurately the precise age of each slope failure event. However, it is interesting that these slumps and debris flows occurred during a time of initiation of the Pleistocene high-frequency glacioeustatic sea-level fluctuations. Major decreases in sea level at this time are thought to be equivalent in magnitude to the most recent fall in glacioeustatic sea level (Wornardt and Vail, 1991) and may have been a key factor in generating mass flows.

An upward-thickening/coarsening sequence between 36 and 40 mbsf (4.9-0.51 Ma) is particularly well developed and may be related to the $0.5-\mathrm{Ma}$ sequence boundary. However, this interval apparently corresponds to the glacial isotopic stage 14 (a eustatic lowstand dated at $\sim 0.50-0.54 \mathrm{Ma}$ ), indicating slight inconsistencies in age estimates (Dick Kroon, written comm., 1992; see Shackleton and Opdyke, 1976). The increased abundance of quartz in turbidite samples at 34 and 37 mbsf $(0.48$ and $0.49 \mathrm{Ma})$ indicates an influx of terrigenous sediment during a eustatic lowstand (possibly the 5.0-Ma sequence boundary of Wornardt and Vail, 1991).

A thick debris-flow deposit at 16.1 to 24.3 mbsf was estimated to be $0.4 \mathrm{Ma}$ in age, which coincides with another sequence boundary and eustatic lowstand (Wornardt and Vail, 1991). The youngest debris flow (1.25-1.85 mbsf) has an estimated age of $0.02 \mathrm{Ma}$, coinciding with the most recent glacial lowstand. Its unusual composition, including very coarse terrigenous quartz, Halimeda, and reworked mudclasts, suggests that the Australia shelf was emergent at this time, which permitted the coarse terrigenous material to be transported to the shelf edge and downslope.

In summary, some of the gravity deposits may correspond with the eustatic sea-level fluctuations of Wornardt and Vail (1991). However, in many ways the above discussion is an exercise in pattern matching and requires focusing on specific intervals/deposits that apparently correspond to the eustatic curve. Geologists are able to find patterns where none exist when using eustatic curves (Miall, 1992) and even when identifying upward-coarsening/thickening sequences of turbidites (Hiscott, 1981). In many cases, the geologist is forced to ignore or explain away gravity deposits that do not match the curves or models. Although our age estimates may be flawed by reworking of microfossils in a turbidite system, our age control is better than that used in most other studies concerning the relationship between turbidites and eustatic curves. In addition, seismic data allowed us to recognize the importance of tectonics and basin setting. Furthermore, our detailed sedimentologic studies shed light on the influence of sedimentary variables. Thus, our study should stand as a warning to geologists who analyze turbidites in deformed rocks that lack either sufficient age control or a well-constrained framework for basin geometry and tectonics. If the turbidites and other gravity deposits of Site 823 were analyzed using only the eustatic curves and available turbidite models, our interpretations would have been much different.

\section{CONCLUSIONS}

1. The Queensland Trough is a marginal basin inherited from rifting during the Cretaceous and Tertiary. Tectonics was important for determining basin and slope geometry, setting the stage for repeated slope failures and gravity deposits. In the late Miocene, renewed tectonic movements caused block faulting, tilting, differential subsidence, and resultant slope instabilities. Seismicity probably triggered some of the sediment gravity flows. During the early late
Miocene, a large slide block apparently became detached from a tilted fault block and slid down a tectonically steepened slope. Associated debris-flow deposits indicate tectonically induced slope instabilities were initiated at approximately 9.0 Ma. Later in the Miocene, alternating debris flows, slumps, turbidites, and hemipelagic sediments filled irregular structural depressions on the seafloor to create the present basin profile.

2. Late Miocene subsidence together with eustatic highstands resulted in the drowning of the Queensland Plateau and northeastern Australia shelf at approximately 6.6 to $6.8 \mathrm{Ma}$ (age estimates may be somewhat in error as a result of the lack of biostratigraphic control). Independent evidence of the deepening of the Queensland Trough (dropping it from middle bathyal to lower bathyal depths) is provided by Katz and Miller (this volume).

3. During the latest Miocene and early Pliocene, the shelves bounding the Queensland Trough remained drowned, but the northeastern Australia continental shelf and slope were blanketed by thick accumulations of hemipelagic mud. Because of gravitational instabilities, muddy slopes failed and triggered slumps and lesser debris flows. Rare turbidites are composed primarily of redeposited planktonic foraminifers. The steep unstable slopes were inherited from previous tectonism along the basin margins, but differential subsidence and minor faulting continued until approximately $3.5 \mathrm{Ma}$.

4. The rejuvenation/shallowing of the northeastern Australia continental shelf was heralded by the influx of turbidites containing quartz and neritic bioclasts, coinciding with a late Pliocene eustatic lowstand at $2.6 \mathrm{Ma}$. Neritic bioclasts (and lesser quartz) became increasingly abundant in Pleistocene turbidites, with a concomitant reduction in planktonic foraminifers.

5. The composition of turbidites reflects their origin. Terrigenous influx occurs during lowstands when shelves are emergent or can result from erosion of tectonically uplifted basement highs. Limestone fragments were eroded from carbonate platforms (on basement highs?) before their ultimate drowning and burial beneath a blanket of hemipelagic sediments. Planktonic foraminifers were reworked from oversteepened slopes and/or drowned shelves. Bioclastic grains and neritic foraminifers were reworked from neritic shelves.

6. Sediment composition affects competency of hemipelagic sediments and thus influences the mechanisms of gravity transport. Mixed mudstone is incompetent and forms the matrix of many debris-flow deposits, whereas calcareous claystone and carbonate oozes were more prone to slumping and sliding.

7. No single sedimentologic variable in turbidites and other gravity deposits of Site 823 can be correlated consistently to the sea-level fluctuations shown on eustatic curves (Haq et al., 1988; Wornardt and Vail, 1991). The influences of tectonics, platform drowning, and multiple sediment sources (including terrigenous sediment and both neritic and pelagic carbonates) either overwhelmed or worked in concert with eustatic controls. Some lack of correlation might be explained by reworking of microfossils in gravity deposits and resultant inaccurate age determinations. The best lowstand indicators are the influx of quartz and bioclasts in turbidites. However, terrigenous quartz can also be supplied during highstands or during times of major sediment influx and/or from tectonic uplift of local source areas.

8. Turbidites and associated gravity deposits do not necessarily indicate submarine fans, particularly in a narrow, tectonically active, marginal basin such as the Queensland Trough. Thus, models for submarine fan sedimentation with migrating channels and prograding lobes do not explain the distribution or interrelationships of different gravity deposits. Instead, the nature of its gravity deposits were more strongly influenced by basin geometry, tectonics, inherent sediment weaknesses, and eustatic lowstands that triggered slope failures. Because these variables can affect large areas, gravity deposits appear to be generated during basinwide events that are traceable across much of the basin, rather than being localized in certain submarine fan environments. 


\section{ACKNOWLEDGMENTS}

Post-cruise research was supported by an NSF grant from the Joint Oceanographic Institutions Incorporated/U.S. Science Advisory Committee. The Geophysical Institute and Department of Geology and Geophysics of the University of Alaska, Fairbanks helped support the preparation of the manuscript and illustrations. Post-cruise revisions of biohorizon positions were provided by Dick Kroon and Wuchang Wei. Dan Lasota modified an existing computerized database to accommodate petrographic data, established a new database for data on bedding characteristics of different gravity deposits, and helped calculate sedimentation rates and estimated ages of the gravity deposits Ellen Harris drafted the figures, and Carol Gering helped with typing. Discussions with other shipboard scientists from Leg 133 provided valuable insights. The paper benefited from reviews by Federico Krause and Allison Palmer. Feary publishes with permission of the Executive Director, Australian Geological Survey Organisation.

\section{REFERENCES}

Belperio, A.P., 1983. Terrigenous sedimentation in the central Great Barrier Reef Lagoon: a model from the Burdekin region. BMR J. Aust. Geol. Geophys., 8:179-190.

Boardman, M.R., and Neumann, A.C., 1984. Sources of periplatform carbonates: Northwest Providence Channel, Bahamas. J. Sediment. Petrol. 54:1110-1123.

Boardman, M.R., Neumann, A.C., Baker, P.A., Dulin, L.A., Kenter, R.A., Hunter, G.E., and Keifer, K.B., 1986. Banktop responses to Quaternary fluctuations in sea level recorded in periplatform sediments. Geology, 14:1039-1041.

Bouma, A.H., 1962. Sedimentology of Some Flysch Deposits: Amsterdam (Elsevier).

Cloetingh, S., 1988. Intraplate stresses: a new element in basin analysis. In Kleinspehn, K.L., and Paola, C. (Eds.), New Perspectives of Basin Analy. sis: New York (Springer-Verlag), 205-230.

Cook, H.E., 1979. Ancient continental slope sequences and their value in understanding modern slope development. In Doyle, L.J., and Pilkey, O.H. (Eds.), Geology of Continental Slopes. Spec. Publ.-Soc. Econ. Paleontol. Mineral., 27:287-305.

Cook, H.E., McDaniel, P.N., Mountjoy, E.W., and Pray, L.C., 1972. Allochthonous carbonate debris flows at Devonian bank ("reef") margins Alberta, Canada. Bull. Can. Pet. Geol., 20:439-497.

Cook, H.E., and Mullins, H.T., 1983. Basin margin. In Scholle, P.A., Bebout, D.G., and Moore, C.H. (Eds.), Carbonate Depositional Environments. AAPG Mem., 33:539-618.

Cook, H.E., and Taylor, M.E, 1977. Comparison of continental slope and shelf environments in the Upper Cambrian and Lowest Ordovician of Nevada. In Cook, H.E., and Enos, P. (Eds.), Deep-Water Carbonate Environments. Spec. Publ.-Soc. Econ. Paleontol. Mineral., 25:51-81.

Davies, G.R., 1977. Turbidites, debris sheets, and truncation structures in upper Paleozoic deep-water carbonates of the Sverdrup Basin, Arctic Archipelago. In Cook, H.E., and Enos, P. (Eds.), Deep-Water Carbonate Environments. Spec. Publ. -Soc. Econ. Paleontol. Mineral., 25:221-247.

Davies, P.J., Symonds, P.A., Feary, D.A., and Pigram, C.J., 1989. The evolution of the carbonate platforms of northeast Australia. In Crevello, P.D. Wilson, J.L., Sarg, J.F., Read, J.F. (Eds.), Controls on Carbonate Platform and Basin Development. Spec. Publ.-Soc. Econ. Paleontol. Mineral., $44: 233-258$

Dolan, J.F., 1989. Eustatic and tectonic controls on deposition of hybrid siliciclastic/carbonate basinal cycles: discussion with examples. AAPG Bull., 73:1233-1246.

Droxler, A.W., and Schlager, W., 1985. Glacial versus interglacial sedimentation rates and turbidite frequency in the Bahamas. Geology, 13:799-802.

Droxler, A.W., Schlager, W., and Whallon, C.C., 1983. Quaternary aragonite cycles and oxygen-isotope record Bahamian carbonate ooze. Geology, 11:235-239.

\footnotetext{
Abbreviations for names of organizations and publication titles in ODP reference lists follow the style given in Chemical Abstracts Service Source Index (published by American Chemical Society).
}

Eberli, G.P., 1987. Carbonate turbidite sequences deposited in rift-basins of the Jurassic Tethys Ocean (eastern Alps, Switzerland). Sedimentology, 34:363-388.

— 1991. Calcareous turbidites and their relationship to sea-level fluctuations and tectonism. In Einsele, G., Ricken, W., and Seilacher, A. (Eds.), Cycles and Events in Stratigraphy: New York (Springer-Verlag), 340-359.

Einsele, G., 1989. In situ water contents, liquid limits, and submarine mass flows due to a high liquefaction potential of slope sediments (results from DSDP and subaerial counterparts). Geol. Rundsch., 78:821-840.

1991. Submarine mass flow deposits and turbidites. In Einsele, G., Ricken, W., and Seilacher, D. (Eds.), Cycles and Events in Stratigraphy: Berlin (Springer-Verlag), 313-339.

Everts, A.J.W., 1991. Interpreting compositional variations of calciturbidites in relation to platform-stratigraphy: an example from the Paleogene of SE Spain. Sediment. Geol., 71:231-242.

Feary, D.A., Pigram, C.J., Davies, P.J., Symonds, P.A., Droxler, A.W., and Peerdeman, F., 1990. Ocean Drilling Program - Leg 133-Northeast Australia safety package. Bur. Miner. Resour. Aust. Rec., 1990/6.

Haak, A.B., and Schlager, W., 1989. Compositional variations in calciturbidites due to sea-level fluctuations, Late Quaternary, Bahamas. Geol. Rundsch. 78:477-486.

Haq, B.U., Hardenbol, J., and Vail, P.R., 1988. Mesozoic and Cenozoic chronostratigraphy and cycles of sea-level change. In Wilgus, C.K., Hastings, B.S., Kendall, C.G.St.C., Posamentier, H.W., Ross, C.A., and Van Wagoner, J.C. (Eds.), Sea-Level Changes-An Integrated Approach. Spec. Publ.-Soc. Econ. Paleontol. Mineral., 42:72-108.

Hesse, R., 1975. Turbiditic and non-turbiditic mudstone of Cretaceous flysch sections of the East Alps and other basins. Sedimentology, 22:387-416.

Hiscott, R.N., 1981. Deep-sea fan deposits in the Macigno Formation (middle-upper Oligocene) of the Gordana Valley, northern Apennines, Italydiscussion. J. Sediment. Petrol., 51:1015-1021.

Hsü, K.J., 1977. Studies of Ventura field, California. I: Facies geometry and genesis of Lower Pliocene Turbidites. AAPG Bull., 61:137-168.

Kendall, C.G.St.C., and Schlager, W., 1981. Carbonates and relative changes in sea level. In Cita, M.B., and Ryan, W.B.F. (Eds.), Carbonate Platforms of the Passive-type Continental Margins, Present and Past. Mar. Geol., 44:181-212.

Kenter, J.A.M., and Schlager, W., 1989. A comparison of shear strength in calcareous and siliciclastic marine sediments. Mar. Geol., 88:125-152.

Krause, F.F., and Oldershaw, A.E., 1979. Submarine carbonate breccia bedsa depositional model for two-layer, sediment gravity flows from the Sekwi Formation (Lower Cambrian), MacKenzie Mountains, Northwest Territories. Can. J. Earth Sci., 16:189-199.

Kuenen, P.H., and Migliorini, C.I., 1950. Turbidity currents as a cause of graded bedding. J. Geol., 58:91-127.

Marshall, J.F., and Davies, P.J., 1978. Skeletal carbonate variations on the continental shelf of eastern Australia. BMR J. Aust. Geol. Geophys. $3: 85-92$.

Miall, A.D., 1992. Exxon global cycle chart: an event for every occasion. Geology, 20:787-790.

Mullins, H.T., 1983. Comment on "Eustatic control of turbidites and winnowed turbidites." Geology, 11:57-58.

Mullins, H.T., and Cook, H.E., 1986. Carbonate apron models. Alternatives to the submarine fan model for paleoenvironmental analysis and hydrocarbon exploration. Sediment. Geol., 48:37-79.

Mutti, E., and Ricci-Lucchi, F., 1978. Turbidites from the northern Apennines: introduction to facies analysis. Int. Geol. Rev., 20:125-166.

Mutti, E., Ricci-Lucchi, F., Seguret, M., and Zanzucchi, G., 1984. Seismoturbidites: a new group of resedimented deposits. Mar Geol.. 55:103-116.

Posamentier, H.W., and Vail, P.R., 1988. Eustatic controls on clastic deposition II-sequence and systems tract models. In Wilgus, C.K., Hastings, B.S., Posamentier, H.W., Van Wagoner, J., Ross, C.A., and Kendall, C.G.St.C. (Eds.), Sea-level Changes: an Integrated Approach. Spec. Publ.-Soc. Econ. Paleontol. Mineral., 42:125-154.

Premoli Silva, I., and Brusa, C., 1981. Shallow-water skeletal debris and larger foraminifers from Deep Sea Drilling Project Site 462, Nauru Basin, western equatorial Pacific. In Larson, R.L., Schlanger, S.O., et al., Init. Repts. DSDP, 61: Washington (U.S. Govt. Printing Office), 439-473.

Read, J.F., 1982. Carbonate platforms of passive (extensional) continental margins: types, characteristics and evolution. Tectonophysics, 81:195212.

Reymer, J.J.G., Schlager, W., and Droxler, A.W., 1988. Site 632: PliocenePleistocene sedimentation cycles in a Bahamian basin. In Austin, J.A., Jr., 
Schlager, W., et al., Proc. ODP, Sci. Results, 101: College Station, TX (Ocean Drilling Program), 213-220.

Reymer, J.J.G., Ten Kate, W.G.H.Z., Sprenger, A., and Schlager, W., 1991 Calciturbidite composition related to exposure and flooding of a carbonate platform (Triassic, Eastern Alps). Sedimentology, 38:1059-1074.

Robertson, A.H.F., and Bliefnick, D.M., 1983. Sedimentology and origin of Lower Cretaceous pelagic carbonates and redeposited clastics, Blake-Bahama Formation, Deep Sea Drilling Project Site 534, western equatorial Atlantic. In Sheridan, R.E., Gradstein, F.M., et al., Init. Repts. DSDP, 76: Washington (U.S. Govt. Printing Office), 795-828.

Rusnak, G.A., and Nesteroff, W.D., 1964. Modern turbidites: terrigenous abyssal plain versus bioclastic basin. In Miller, R.L. (Ed.), Papers in Marine Geology: New York (MacMillan), 488-507.

Sarg, J.F., 1988. Carbonate sequence stratigraphy. In Wilgus, C.K., Hastings, B.S., Posamentier, H.W., Van Wagoner, J., Ross, C.A., and Kendall, C.G.St.C. (Eds.), Sea-Level Changes: An Integrated Approach. Soc. Econ. Paleont. and Mineral. Spec. Publ., 42:155-182.

Schlager, W., 1980. Mesozoic calciturbidites in Deep Sea Drilling Project Hole 416A: recognition of a drowned carbonate platform. In Lancelot, Y., Winterer, E.L., et al., Init. Repts. DSDP, 50: Washington (U.S. Govt. Printing Office), 733-749.

_ 1981. The paradox of drowned reefs and carbonate platforms. Geol. Soc. Am. Bull., 92:197-211.

Schlanger, S.O., and Premoli Silva, I., 1986. Oligocene sea-level falls recorded in mid-Pacific atoll and archipelagic apron settings. Geology, 14:392-395.

Scholle, P.A., 1971. Sedimentology of fine-grained deep-water carbonate turbidites, Monte Antola Flysch (Upper Cretaceous), Northern Apennines, Italy. Geol. Soc. Am. Bull., 82:629-658.

Scholle, P.A., Arthur, M.A., and Ekdale, A.A., 1983. Pelagic environments. In Scholle, P.A., Bebout, D.G., and Moore, C.H. (Eds.), Carbonate Depositional Environments. AAPG Mem., 33:620-691.

Shackleton, N.J., and Opdyke, N.D., 1976. Oxygen-isotope and paleomagnetic stratigraphy of Pacific Core V28-239: late Pliocene to latest Pleistocene. In Cline, R.M., and Hays, J.D. (Eds.), Investigations of Late Quaternary Paleoceanography and Paleoclimatology. Mem.-Geol. Soc. Am. 145:449-464.

Shanmugam, G., and Moiola, R.J., 1982. Eustatic control of turbidites and winnowed turbidites. Geology, 10:231-235.

- 1984. Eustatic control of calciclastic turbidites. Mar. Geol. 56:273-278.

Shipboard Scientific Party, 1991. Site 823. In Davies, P.J., McKenzie, J.A., Palmer-Julson, A., et al., Proc. ODP, Init. Repts., 133 (Pt. 1): College Station, TX (Ocean Drilling Program), 679-768.

Stanley, D.J., 1985. Mud depositional processes as a major influence on Mediterranean margin-basin sedimentation. In Stanley, D.J., and Wezel, F.C. (Eds.), Geological Evolution of the Mediterranean Basin: New York (Springer), 377-410.
Stow, D.A.V., Howell, D.G., and Nelson, C.H., 1985. Sedimentary, tectonic and sea-level controls. In Bouma, A.H., Normark, W.R., and Barnes, N.E. (Eds.), Submarine Fans and Related Turbidite Systems: New York (Springer-Verlag), 15-22.

Stow, D.A.V., and Piper, D.J.W., 1984. Deep-water fine-grained sediments: facies models. In Stow, D.A.V., and Piper, D.J.W. (Eds.), Fine-grained Sediments: Deep-Water Processes and Facies: Oxford (Blackwell), 15:611-645.

Symonds, P.A., Davies, P.J., and Parisi, A., 1983. Structure and stratigraphy of the central Great Barrier Reef. BMR J.Aust. Geol. Geophys., 8:277-291.

Thiede, J., 1981. Reworked neritic fossils in upper Mesozoic and Cenozoic central Pacific deep-sea sediments monitor sea-level changes. Science, 211:1422-1424.

Vail, P.R., Mitchum, R.M., Jr., Todd, R.G., Widmier, J.M., Thompson, S., III, Sangree, J.B., Bubb, J.N., and Hatlelid, W.G., 1977. Seismic stratigraphy and global changes in sea level. In Payton, C.E. (Ed.), Seismic Stratigraphy-Applications to Hydrocarbon Exploration. AAPG Mem., 26:49221.

Walker, R.G., 1978. Deep-water sandstone facies and ancient submarine fans: models for exploration of stratigraphic traps. AAPG Bull., 62:932-966.

1984. Turbidites and associated coarse-grained clastic deposits. In Walker, R.G. (Ed.), Facies Models (2nd ed.). Geol. Assoc. Can., Geosci. Reprint Ser., 1:171-188.

Watts, K.F., and Blome, C.D., 1990. Evolution of the Arabian platform margin slope and its response to orogenic closing of an ocean basin, Cretaceous, Oman. In Tucker, M.E., Wilson, J.L., Crevello, P.D., Sarg, J.R., and Read, J.F. (Eds.), Carbonate Platforms: Facies, Sequences and Evolution. Spec. Publ. Int. Assoc. Sedimentol., 9:291-323.

Watts, K.F., and Garrison, R.E., 1986. Sumeini Group, Oman - evolution of a Mesozoic continental slope on a south Tethyan margin. Sediment. Geol., 48:107-168.

Wornardt, W.W., and Vail, P.R., 1991. Revision of the Plio-Pleistocene cycles and their application to sequence stratigraphy and shelf and slope sediments in the Gulf of Mexico. Trans. Gulf Coast Assoc. Geol. Soc. 41:719-744.

Yose, L.A., and Heller, P.L., 1989. Sea-level control of mixed-carbonate-siliciclastic, gravity-flow deposition: lower part of the Keeler Canyon Formation (Pennsylvanian), southeastern California. Geol. Soc. Am. Bull., 101:427-439.

Date of initial receipt: 22 May 1992

Date of acceptance: 14 January 1993

Ms 133SR-248 
APPENDIX A

Bedding Characteristics, Sedimentary Structures, and Depositional Mechanisms of Turbidites, Debris Flows, and Slump Deposits at Site 823 (Computerized Data Only for the Upper $500 \mathrm{~m}$ of Recovered Core)

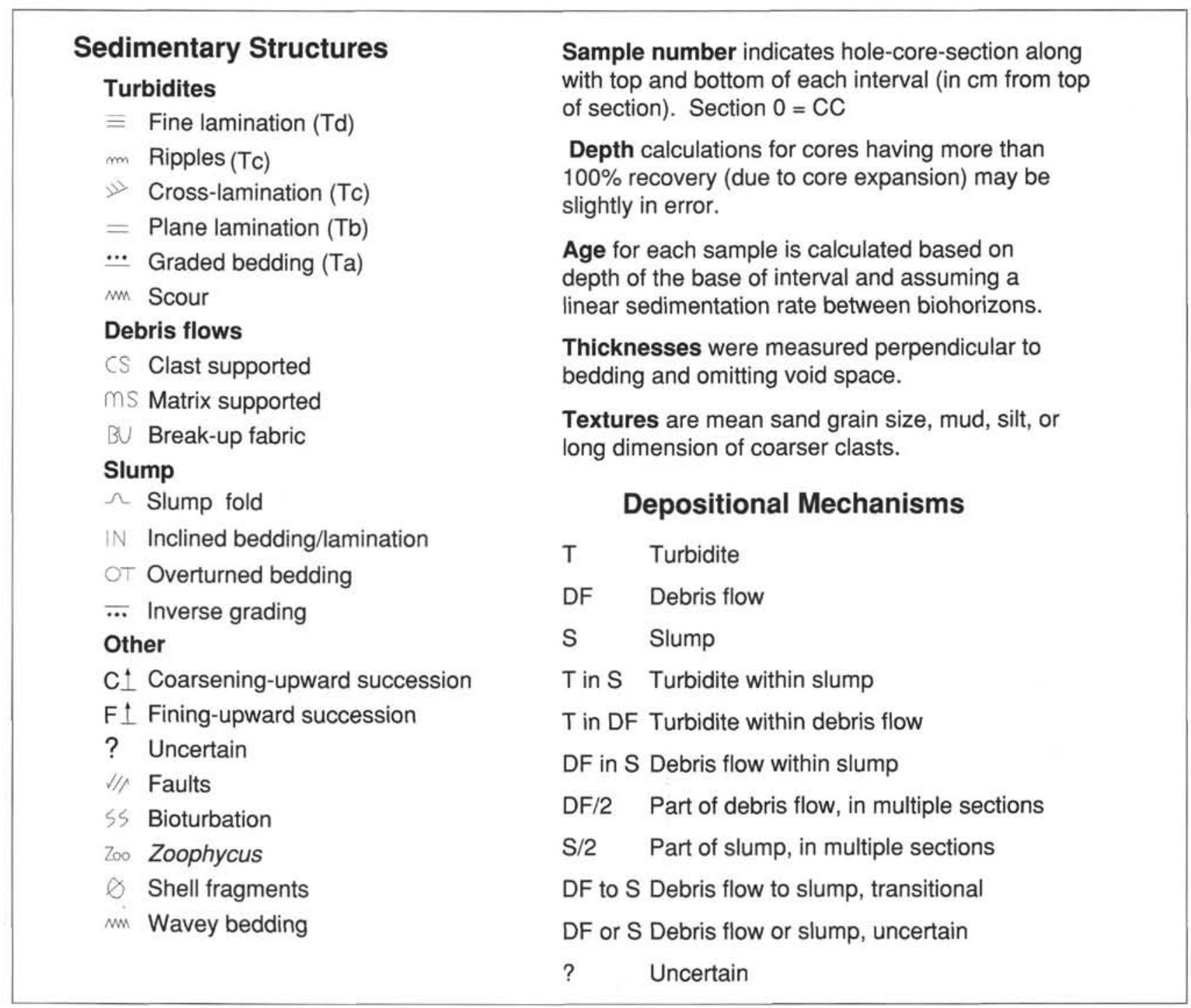


Appendix A (continued).

\begin{tabular}{|c|c|c|c|c|c|c|c|c|c|c|c|}
\hline Sample & Top $(\mathrm{cm})$ & $\begin{array}{c}\text { Bottom } \\
(\mathrm{cm})\end{array}$ & Depth (m) & $\begin{array}{l}\text { Age } \\
(\mathrm{ma})\end{array}$ & Thickness (cm) & Texture Base & Texture Top & Mud cap & $\begin{array}{l}\text { Sedimentary } \\
\text { Structure }\end{array}$ & $\begin{array}{l}\text { Depositional } \\
\text { Mechanism } \\
\end{array}$ & ? \\
\hline $823 \mathrm{~A}-1 \mathrm{H}-1$ & 39 & 40 & 0.4 & 0 & 1.2 & vC & & & & & ? \\
\hline $823 \mathrm{~A}-1 \mathrm{H}-1$ & 125 & 150 & 1.5 & 0.02 & 24 & $\mathrm{VF}$ & $13 \mathrm{~cm}$ & & $\operatorname{CsBN}$ & $\mathrm{DF} / 2$ & \\
\hline $823 \mathrm{~A}-1 \mathrm{H}-2$ & 0 & 35 & 1.85 & 0.02 & 34 & VF & $7.2 \mathrm{~cm}$ & & $\operatorname{csB}$ & $\mathrm{DF} / 2$ & \\
\hline $823 \mathrm{~A}-1 \mathrm{H}-2$ & 0 & 35 & 1.85 & 0.02 & 58 & VF & $7.2 \mathrm{~cm}$ & & $\operatorname{CSBU}$ & DF & \\
\hline $823 \mathrm{~A}-1 \mathrm{H}-2$ & 64 & 66 & 2.16 & 0.02 & 1.5 & $\mathrm{~F}$ & VF/silt & & ми…SS & $\mathrm{T}$ & \\
\hline $823 \mathrm{~A}-1 \mathrm{H}-2$ & 104 & 108 & 2.58 & 0.03 & 2.6 & $\mathrm{~F}$ & VF/silt & & mи...SS & $\mathrm{T}$ & \\
\hline $823 \mathrm{~A}-1 \mathrm{H}-3$ & 12 & 13 & 3.13 & 0.04 & 1.2 & $\mathrm{~F}$ & VF & mud & mm...SS & $T$ & \\
\hline $823 \mathrm{~A}-1 \mathrm{H}-3$ & 24 & 28 & 3.28 & 0.04 & 2.4 & F & VF & mud & mm...SS & $\mathrm{T}$ & \\
\hline $823 \mathrm{~A}-1 \mathrm{H}-3$ & 66 & 69 & 3.69 & 0.04 & 2.2 & F & VF & & ...S5 & $\mathrm{T}$ & \\
\hline $823 \mathrm{~A}-1 \mathrm{H}-4$ & 83 & 84 & 5.34 & 0.06 & 1.1 & F & VF & & ...SS & $\mathrm{T}$ & \\
\hline $823 \mathrm{~A}-1 \mathrm{H}-4$ & 95 & 99 & 5.49 & 0.06 & 3.8 & $\mathrm{~F} / \mathrm{VF}$ & VF & & ..5S & $\mathrm{T}$ & \\
\hline $823 \mathrm{~A}-2 \mathrm{H}-2$ & 51 & 52 & 7.82 & 0.09 & 1.5 & $\mathrm{VF}(\mathrm{C})$ & silt & & ...SS & $\mathrm{T}$ & \\
\hline $823 \mathrm{~A}-2 \mathrm{H}-2$ & 87 & 88 & 8.18 & 0.09 & 1 & M & mud & & & $\mathrm{T}$ & ? \\
\hline $823 \mathrm{~A}-2 \mathrm{H}-3$ & 11 & 13 & 8.93 & 0.1 & 2.1 & $\mathrm{~F} / \mathrm{M}$ & $\mathrm{F}$ & & ‥ & $\mathrm{T}$ & \\
\hline $823 \mathrm{~A}-2 \mathrm{H}-3$ & 38 & 42 & 9.22 & 0.1 & 4 & $\mathrm{~F} / \mathrm{M}$ & $\mathrm{F}$ & & .. & $\mathrm{T}$ & \\
\hline $823 \mathrm{~A}-2 \mathrm{H}-3$ & 73 & 74 & 9.54 & 0.11 & 1 & $\mathrm{~F} / \mathrm{VF}$ & VF/silt & & \#SS & $\mathrm{T}$ & \\
\hline $823 \mathrm{~A}-2 \mathrm{H}-3$ & 84 & 87 & 9.67 & 0.11 & 4.2 & F/VF & VF/silt & & mn… & $\mathrm{T}$ & \\
\hline $823 \mathrm{~A}-2 \mathrm{H}-4$ & 98 & 99 & 11.29 & 0.19 & 0.6 & VF/silt & mud & & 55 & $\mathrm{~T}$ & \\
\hline $823 \mathrm{~A}-2 \mathrm{H}-4$ & 120 & 123 & 11.53 & 0.22 & 0.3 & VF & mud & & mn…SS & $\mathrm{T}$ & \\
\hline $823 \mathrm{~A}-2 \mathrm{H}-4$ & 134 & 137 & 11.67 & 0.23 & 2.8 & $\mathrm{~F}$ & VF & & ...SS & $\mathrm{T}$ & \\
\hline $823 \mathrm{~A}-2 \mathrm{H}-5$ & 4 & 10 & 11.9 & 0.25 & 5.5 & $\mathrm{~F}$ & VF & & \#SS & $T$ & \\
\hline $823 \mathrm{~A}-2 \mathrm{H}-5$ & 131 & 132 & 13.12 & 0.29 & 1 & $\mathrm{~F} / \mathrm{M}$ & & & & $T$ & \\
\hline $823 \mathrm{~A}-2 \mathrm{H}-6$ & 137 & 140 & 14.67 & 0.3 & 3.5 & $\mathrm{~F}$ & VF/silt & & ...SS & $\mathrm{T}$ & \\
\hline $823 \mathrm{~A}-2 \mathrm{H}-7$ & 3 & 23 & 14.83 & 0.31 & 19.6 & $\mathrm{~F} / \mathrm{M}$ & $\mathrm{F} / \mathrm{VF}$ & & mn…SS & $\mathrm{T}$ & \\
\hline $823 \mathrm{~A}-2 \mathrm{H}-6$ & 22 & 25 & 16.05 & 0.32 & 2.8 & $F$ & VF/silt & & ...SS & $\mathrm{T}$ & \\
\hline $823 \mathrm{~A}-3 \mathrm{H}-1$ & 95 & 102 & 16.32 & 0.32 & 2.5 & $\mathrm{~F}$ & VF & & mon $\Omega$ & $\mathrm{T}$ in $\mathrm{DF}$ & \\
\hline $823 \mathrm{~A}-3 \mathrm{H}-1$ & 123 & 125 & 16.55 & 0.32 & 0.5 & VF & silt & & IN m $\ldots$ & $\mathrm{T}$ in $\mathrm{DF}$ & \\
\hline $823 \mathrm{~A}-3 \mathrm{H}-1$ & 86 & 150 & 16.8 & 0.32 & 64 & mud & $5.5 \mathrm{~cm}$ & & $\mathrm{IN} \Omega \mathrm{BU} \mathrm{ms}$ & $D F$ to $S / 2$ & \\
\hline $823 \mathrm{~A}-3 \mathrm{H}-2$ & 0 & 150 & 18.3 & 0.34 & 150 & mud & $5 \mathrm{~cm}$ & & $\mathrm{IN} \Omega \mathrm{BU} \mathrm{mS}$ & $\mathrm{DF}$ to $\mathrm{S} / 2$ & \\
\hline $823 \mathrm{~A}-3 \mathrm{H}-3$ & 0 & 150 & 19.8 & 0.35 & 150 & & & & BUms $\Omega$ & $\mathrm{DF} / 2$ & \\
\hline $823 \mathrm{~A}-3 \mathrm{H}-4$ & 0 & 150 & 21.3 & 0.37 & 150 & mud & $15 \mathrm{~cm}$ & & mS $\Omega B U C S$ & $\mathrm{DF} / 2$ & \\
\hline $823 \mathrm{~A}-3 \mathrm{H}-5$ & 0 & 121 & 22.51 & 0.38 & 121 & mud & $11 \mathrm{~cm}$ & & $\mathrm{mS} \Omega \mathrm{BN}$ & $\mathrm{DF} / 2$ & \\
\hline $823 \mathrm{~A}-3 \mathrm{H}-6$ & 0 & 52 & 23.32 & 0.39 & 52 & mud & $3 \mathrm{~cm}$ & & $\mathrm{mS} \mathrm{IN}$ & $\mathrm{DF}$ in $\mathrm{S} / 2$ & \\
\hline $823 \mathrm{~A}-3 \mathrm{H}-6$ & 51 & 57 & 23.37 & 0.39 & 1.7 & VF/silt & VF & & SS $\overline{-}_{\text {m }}$ OT IN & $\mathrm{T}$ in $\mathrm{S}$ & \\
\hline $823 \mathrm{~A}-3 \mathrm{H}-6$ & 59 & 65 & 23.45 & 0.39 & 1.5 & $\mathrm{VF} /$ silt & VF & & SS m $_{\text {m OT IN }}$ & $\mathrm{T}$ in $\mathrm{S}$ & \\
\hline $823 \mathrm{~A}-3 \mathrm{H}-6$ & 105 & 106 & 23.86 & 0.39 & 1.6 & VF & VF/silt & & mm & $\mathrm{T}$ in $\mathrm{S}$ & \\
\hline $823 \mathrm{~A}-3 \mathrm{H}-6$ & 111 & 113 & 23.93 & 0.39 & 1.5 & VF & VF/silt & & mи…SS & $\mathrm{T}$ in $\mathrm{S}$ & \\
\hline $823 \mathrm{~A}-3 \mathrm{H}-6$ & 114 & 150 & 24.3 & 0.4 & 36.5 & mud & $5.5 \mathrm{~cm}$ & & ms & $\mathrm{DF}$ in $\mathrm{S} / 2$ & \\
\hline $823 \mathrm{~A}-3 \mathrm{H}-6$ & 0 & 150 & 24.3 & 0.4 & 150 & & & & $\mathrm{~ms} \Omega$ & $\mathrm{DF}$ to $\mathrm{S} / 2$ & \\
\hline $823 \mathrm{~A}-3 \mathrm{H}-6$ & 0 & 150 & 24.3 & 0.4 & 814 & & & & $\mathrm{mS} \Omega$ & DF & \\
\hline $823 \mathrm{~A}-4 \mathrm{H}-1$ & 45 & 46 & 25.26 & 0.41 & 0.8 & VF & VF/silt & & mm…SS & $\mathrm{T}$ & \\
\hline $823 \mathrm{~A}-4 \mathrm{H}-1$ & 46 & 47 & 25.27 & 0.41 & 0.8 & VF & VF/silt & & & $\mathrm{T}$ & \\
\hline $823 \mathrm{~A}-4 \mathrm{H}-1$ & 48 & 49 & 25.29 & 0.41 & 0.9 & $\mathrm{~F}$ & VF/silt & & m늗S & $\mathrm{T}$ & \\
\hline $823 \mathrm{~A}-4 \mathrm{H}-1$ & 57 & 63 & 25.43 & 0.41 & 5.9 & $\mathrm{~F}$ & VF/silt & & & $\mathrm{T}$ & \\
\hline $823 \mathrm{~A}-4 \mathrm{H}-2$ & 5 & 6 & 26.36 & 0.42 & 0.2 & silt & mud & & muSS & $\mathrm{T}$ & \\
\hline $823 \mathrm{~A}-4 \mathrm{H}-2$ & 32 & 33 & 26.63 & 0.42 & 0.6 & VF & mud & & mm…SS & $\mathrm{T}$ & \\
\hline $823 \mathrm{~A}-4 \mathrm{H}-2$ & 67 & 70 & 27 & 0.42 & 0.5 & VF & mud & & muss & $\mathrm{T}$ & \\
\hline $823 \mathrm{~A}-4 \mathrm{H}-3$ & 6 & 8 & 27.88 & 0.43 & 2 & VF & silt & & мm… & $\mathrm{T}$ & \\
\hline $823 \mathrm{~A}-4 \mathrm{H}-3$ & 52 & 53 & 28.33 & 0.44 & 0.7 & VF & & & miss & $\mathrm{T}$ & \\
\hline $823 \mathrm{~A}-4 \mathrm{H}-3$ & 126 & 127 & 29.07 & 0.44 & 0.2 & VF & & & minsS & $\mathrm{T}$ & \\
\hline $823 \mathrm{~A}-4 \mathrm{H}-4$ & 34 & 35 & 29.65 & 0.45 & 1.2 & VF & VF/silt & & mm…SS & $\mathrm{T}$ & \\
\hline $823 \mathrm{~A}-4 \mathrm{H}-4$ & 49 & 52 & 29.82 & 0.45 & 4 & $\mathrm{~F}$ & $\mathrm{VF} / \mathrm{mud}$ & & mm...SS & $\mathrm{T}$ & \\
\hline $823 \mathrm{~A}-4 \mathrm{H}-4$ & 109 & 110 & 30.4 & 0.46 & 0.4 & $\mathrm{VF}$ & & & SS & $\mathrm{T}$ & \\
\hline $823 \mathrm{~A}-4 \mathrm{H}-4$ & 131 & 132 & 30.62 & 0.46 & 1.1 & VF & $\mathrm{VF} / \mathrm{mud}$ & & $m m \cdots S S$ & $\mathrm{~T}$ & \\
\hline $823 \mathrm{~A}-4 \mathrm{H}-4$ & 148 & 150 & 30.8 & 0.46 & 3.6 & $\mathrm{~F}$ & VF/mud & & ...SS & $\mathrm{T} / 2$ & \\
\hline $823 \mathrm{~A}-4 \mathrm{H}-5$ & 0 & 2 & 30.82 & 0.46 & 5.8 & vC & M & & мm… & $T$ & \\
\hline $823 \mathrm{~A}-4 \mathrm{H}-5$ & 4 & 8 & 30.88 & 0.46 & 3.9 & VF & silt/VF & & mu…SS & $T$ & \\
\hline $823 \mathrm{~A}-4 \mathrm{H}-5$ & 44 & 50 & 31.3 & 0.46 & 1.8 & $\mathrm{~F}$ & VF/silt & mud & IN SS m … SS & $\mathrm{T}$ in $\mathrm{S}$ & ? \\
\hline $823 \mathrm{~A}-4 \mathrm{H}-5$ & 59 & 62 & 31.42 & 0.46 & 1.1 & $\mathrm{~F}$ & VF & mud & IN SS m …SS & $\mathrm{T}$ in $\mathrm{S}$ & \\
\hline $823 \mathrm{~A}-4 \mathrm{H}-5$ & 32 & 62 & 31.42 & 0.46 & 30 & F & VF/silt & mud & INSS m … SS & $\mathrm{S}$ & ? \\
\hline $823 \mathrm{~A}-4 \mathrm{H}-5$ & 114 & 118 & 31.98 & 0.47 & 4 & $\mathrm{~F}$ & $\mathrm{VF} /$ silt & & SS & $\mathrm{T}$ & \\
\hline $823 \mathrm{~A}-4 \mathrm{H}-6$ & 1 & 4 & 32.34 & 0.47 & 1.1 & VF & silt & mud & mm...SS & $\mathrm{T}$ & \\
\hline $823 \mathrm{~A}-4 \mathrm{H}-6$ & 145 & 150 & 33.8 & 0.48 & 6 & $\mathrm{~F}$ & & & $=$ & $\mathrm{T}$ & \\
\hline $823 \mathrm{~A}-4 \mathrm{H}-7$ & 23 & 24 & 34.04 & 0.48 & 0.5 & VF & silt & & мм… & $\mathrm{T}$ & \\
\hline
\end{tabular}


Appendix A (continued).

\begin{tabular}{|c|c|c|c|c|c|c|c|c|c|c|c|}
\hline Sample & Top (cm) & $\begin{array}{c}\text { Bottom } \\
(\mathrm{cm}) \text { I }\end{array}$ & Depth (m) & $\begin{array}{c}\text { Age } \\
\text { (ma) }\end{array}$ & Thickness $(\mathrm{cm})$ & Texture Base & Texture Top & Mud cap & $\begin{array}{c}\text { Sedimentary } \\
\text { Structure }\end{array}$ & $\begin{array}{l}\text { Depositional } \\
\text { Mechanism }\end{array}$ & ? \\
\hline $823 \mathrm{~A}-4 \mathrm{H}-7$ & 32 & 37 & 34.17 & 0.48 & 0.4 & $\mathrm{~F}$ & $\mathrm{VF}$ & & 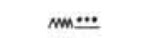 & $T$ & \\
\hline $823 \mathrm{~A}-4 \mathrm{H}-7$ & 42 & 43 & 34.23 & 0.48 & 1.1 & $\mathrm{~F}$ & $\mathrm{~F} / \mathrm{VF}$ & & $\ldots$ & $T$ & \\
\hline $823 \mathrm{~A}-4 \mathrm{H}-0$ & 1 & 3 & 34.26 & 0.48 & 3 & $\mathrm{~F}$ & & & mn & T & \\
\hline $823 \mathrm{~A}-5 \mathrm{H}-1$ & 34 & 50 & 34.8 & 0.48 & 14 & $\mathrm{~F} / \mathrm{M}$ & VF & & $\operatorname{sn} \cdots$ & T & \\
\hline $823 \mathrm{~A}-5 \mathrm{H}-1$ & 83 & 134 & 35.64 & 0.49 & 50.8 & $\mathrm{M} / \mathrm{C}$ & VF & mud & 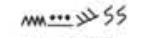 & $T$ & \\
\hline $823 \mathrm{~A}-5 \mathrm{H}-2$ & 26 & 41 & 36.21 & 0.49 & 17.8 & $\mathrm{~F}$ & VF & mud & ми…SS & $\mathrm{T}$ & \\
\hline $823 \mathrm{~A}-5 \mathrm{H}-2$ & 64 & 106 & 36.86 & 0.49 & 41.6 & $\mathrm{M} / \mathrm{C}$ & $\mathrm{VF}$ & & mm....SS & $T$ & \\
\hline $823 \mathrm{~A}-5 \mathrm{H}-2$ & 112 & 115 & 36.95 & 0.49 & 3.1 & $\mathrm{~F}$ & VF & mud & 쓰…SS & $\mathrm{T}$ & \\
\hline $823 \mathrm{~A}-5 \mathrm{H}-3$ & 2 & 5 & 37.35 & 0.5 & 2.5 & $F / V F$ & VF & mud & …SS & $T$ & \\
\hline $823 \mathrm{~A}-5 \mathrm{H}-3$ & 16 & 20 & 37.5 & 0.5 & 3.6 & F/VF & VF & mud & $S S_{\text {m. }} \ldots$...SS & $\mathrm{T}$ & \\
\hline $823 \mathrm{~A}-5 \mathrm{H}-3$ & 40 & 70 & 38 & 0.5 & 30.8 & $\mathrm{~F} / \mathrm{M}$ & VF & & $m n \cdots=S S$ & T & \\
\hline $823 \mathrm{~A}-5 \mathrm{H}-3$ & 85 & 91 & 38.21 & 0.5 & 6 & $\mathrm{~F}$ & VF & & мm… & $\mathrm{T}$ & \\
\hline $823 \mathrm{~A}-5 \mathrm{H}-3$ & 97 & 115 & 38.45 & 0.5 & 18.5 & $\mathrm{~F} / \mathrm{M}$ & VF & & $\operatorname{sn} \cdots$ & T & \\
\hline $823 \mathrm{~A}-5 \mathrm{H}-3$ & 138 & 150 & 38.8 & 0.5 & 12.3 & $\mathrm{C} / \mathrm{M}$ & & & ‥ & $\mathrm{T}$ & \\
\hline $823 \mathrm{~A}-5 \mathrm{H}-4$ & 0 & 9 & 38.89 & 0.5 & 8.8 & $\mathrm{M}$ & & & $m m \cdots$ & $\mathrm{T}$ & \\
\hline $823 \mathrm{~A}-5 \mathrm{H}-4$ & 9 & 30 & 39.1 & 0.51 & 22 & $\mathrm{~F} / \mathrm{M}$ & VF & & SS & $T$ & \\
\hline $823 \mathrm{~A}-5 \mathrm{H}-4$ & 57 & 58 & 39.38 & 0.51 & 0.7 & $\mathrm{VF} / \mathrm{F}$ & VF & & mu…SS & $T$ & \\
\hline $823 \mathrm{~A}-5 \mathrm{H}-4$ & 78 & 84 & 39.64 & 0.51 & 6.7 & $\mathrm{~F} / \mathrm{M}$ & VF & & 느로 & T & \\
\hline $823 \mathrm{~A}-5 \mathrm{H}-4$ & 98 & 132 & 40.12 & 0.51 & 33.3 & $\mathrm{~F} / \mathrm{M}$ & VF & & mm...SSS & T & \\
\hline $823 \mathrm{~A}-5 \mathrm{H}-4$ & 149 & 150 & 40.3 & 0.51 & 1 & VF & silt & mud & ㅍ-35 & $\mathrm{T}$ & \\
\hline $823 \mathrm{~A}-5 \mathrm{H}-5$ & 0 & 43 & 40.73 & 0.51 & 43 & $\mathrm{~F} / \mathrm{M}$ & & & m & $\mathrm{T}$ & \\
\hline $823 \mathrm{~A}-5 \mathrm{H}-5$ & 66 & 79 & 41.09 & 0.52 & 12.2 & $\mathrm{~F}$ & silt & & …SS & T & \\
\hline $823 \mathrm{~A}-5 \mathrm{H}-5$ & 96 & 101 & 41.31 & 0.52 & 5.7 & $\mathrm{~F}$ & silt & mud & sm…SS & $\mathrm{T}$ & \\
\hline $823 \mathrm{~A}-5 \mathrm{H}-5$ & 116 & 117 & 41.47 & 0.52 & 0.3 & VF & silt & mud & мm․ㅡSS & $\mathrm{T}$ & \\
\hline $823 \mathrm{~A}-5 \mathrm{H}-6$ & 12 & 23 & 42.03 & 0.52 & 10.5 & $\mathrm{~F}$ & VF & mud & m․․ㅗs & $\mathrm{T}$ & \\
\hline $823 \mathrm{~A}-5 \mathrm{H}-6$ & 73 & 112 & 42.92 & 0.52 & 38.5 & $\mathrm{M}(\mathrm{C})$ & VF & mud & mm...SS & $\mathrm{T}$ & \\
\hline $823 \mathrm{~A}-5 \mathrm{H}-6$ & 112 & 150 & 43.3 & 0.53 & 38 & mud & 5 & & msss $\Omega$ & DF & \\
\hline $823 \mathrm{~A}-6 \mathrm{H}-1$ & 33 & 39 & 44.19 & 0.53 & 2.6 & $\mathrm{~F}$ & VF & mud & мm…SS & $T$ & \\
\hline $823 \mathrm{~A}-6 \mathrm{H}-1$ & 56 & 58 & 44.38 & 0.53 & 1.6 & $\mathrm{~F}$ & VF & & nmㅡ. $\Omega$ & $\mathrm{T}$ & \\
\hline $823 \mathrm{~A}-6 \mathrm{H}-1$ & 91 & 92 & 44.72 & 0.53 & 0.6 & VF & $\mathrm{VF} /$ silt & & $m n=\ldots S$ & $\mathrm{~T}$ & \\
\hline $823 \mathrm{~A}-6 \mathrm{H}-1$ & 118 & 128 & 45.08 & 0.54 & 10.5 & $\mathrm{~F}$ & VF & mud & мm…SS & $\mathrm{T}$ & \\
\hline $823 \mathrm{~A}-6 \mathrm{H}-2$ & 11 & 16 & 45.46 & 0.54 & 3.8 & $\mathrm{~F}$ & VF & mud & \#SSS & $\mathrm{T}$ & \\
\hline $823 \mathrm{~A}-6 \mathrm{H}-2$ & 38 & 39 & 45.69 & 0.54 & 0.5 & $\mathrm{C} / \mathrm{F}$ & & & & $\mathrm{T}$ & \\
\hline $823 \mathrm{~A}-6 \mathrm{H}-2$ & 63 & 82 & 46.12 & 0.54 & 18 & VF & mud & & \#SSS & $\mathrm{T}$ & \\
\hline $823 \mathrm{~A}-6 \mathrm{H}-2$ & 110 & 111 & 46.41 & 0.54 & 1.3 & VF & mud & & mm...SS & $\mathrm{T}$ & \\
\hline $823 \mathrm{~A}-6 \mathrm{H}-3$ & 0 & 16 & 46.96 & 0.54 & 16 & M & $\mathrm{VF}$ & & ㅍ & $\mathrm{T}$ & \\
\hline $823 \mathrm{~A}-6 \mathrm{H}-3$ & 21 & 22 & 47.02 & 0.55 & 0.7 & $\mathrm{~F}$ & & & mn & T & \\
\hline $823 \mathrm{~A}-6 \mathrm{H}-3$ & 66 & 75 & 47.55 & 0.55 & 0.7 & $\mathrm{~F} / \mathrm{M}$ & & & & & $?$ \\
\hline $823 \mathrm{~A}-6 \mathrm{H}-3$ & 88 & 90 & 47.7 & 0.55 & 1.8 & $\mathrm{~F}$ & VF & & \#SSS & T & \\
\hline $823 \mathrm{~A}-6 \mathrm{H}-3$ & 112 & 151 & 48.31 & 0.55 & 39.4 & F & $\mathrm{F} / \mathrm{M}$ & & $\overline{\ldots . . .5 S}$ & $\mathrm{~T}$ & \\
\hline $823 \mathrm{~A}-6 \mathrm{H}-4$ & 0 & 19 & 48.49 & 0.55 & 19 & $\mathrm{~F}$ & VF & & $S S_{\text {m..... }}$ & $\mathrm{T}$ & \\
\hline $823 \mathrm{~A}-6 \mathrm{H}-4$ & 19 & 150 & 49.8 & 0.56 & 131 & mud & $10.5 \mathrm{~cm}$ & & CSBU & $\mathrm{DF} / 2$ & \\
\hline $823 \mathrm{~A}-6 \mathrm{H}-5$ & 0 & 119 & 50.99 & 0.56 & 119 & mud & $6.7 \mathrm{~cm}$ & & CSBN & $\mathrm{DF} / 2$ & \\
\hline $823 \mathrm{~A}-6 \mathrm{H}-6$ & 0 & 150 & 52.8 & 0.57 & 150 & mud & $17 \mathrm{~cm}$ & & $\operatorname{CSBU} \Omega$ & $\mathrm{DF} / 2$ & \\
\hline $823 \mathrm{~A}-6 \mathrm{H}-7$ & 0 & 70 & 53.5 & 0.58 & 70 & mud & $6.3 \mathrm{~cm}$ & & IN $\mathrm{ms}$ & DF or $S / 2$ & \\
\hline $823 \mathrm{~A}-6 \mathrm{H}-0$ & 0 & 25 & 53.66 & 0.58 & 24.5 & mud & $11 \mathrm{~cm}$ & & CS & $\mathrm{DF} / 2$ & $?$ \\
\hline $823 \mathrm{~A}-6 \mathrm{H}-0$ & 0 & 25 & 53.66 & 0.58 & 526 & mud & $11 \mathrm{~cm}$ & & CS & DF & ? \\
\hline $823 \mathrm{~A}-7 \mathrm{H}-1$ & 73 & 74 & 54.04 & 0.58 & 0.2 & $\mathrm{M}$ & & & & $\mathrm{T}$ & \\
\hline $823 \mathrm{~A}-7 \mathrm{H}-1$ & 109 & 110 & 54.4 & 0.58 & 0.2 & $\mathrm{VF} / \mathrm{F}$ & & & $\underline{-1}$ & $\mathrm{~T}$ in $\mathrm{S}$ & \\
\hline $823 \mathrm{~A}-7 \mathrm{H}-1$ & 126 & 128 & 54.58 & 0.58 & 1.5 & silt & $\mathrm{F}$ & & $\bar{m}_{\text {mOT }}$ & $\mathrm{T}$ in $\mathrm{S}$ & \\
\hline $823 \mathrm{~A}-7 \mathrm{H}-1$ & 133 & 134 & 54.64 & 0.58 & 0.3 & silt & VF & & $\bar{\cdots}$ & $\mathrm{T}$ in $\mathrm{S}$ & ? \\
\hline $823 \mathrm{~A}-7 \mathrm{H}-1$ & 104 & 134 & 54.64 & 0.58 & 30 & silt & VF & & $\bar{\cdots}$ & $\mathrm{s}$ & ? \\
\hline $823 \mathrm{~A}-7 \mathrm{H}-2$ & 11 & 12 & 54.92 & 0.58 & 0.2 & VF & silt & & sm $\ldots$ IN & $\mathrm{T}$ in $\mathrm{S}$ & \\
\hline $823 \mathrm{~A}-7 \mathrm{H}-2$ & 17 & 22 & 55.02 & 0.58 & 1.5 & VF & silt & & ми 피 IN & $\mathrm{T}$ in $\mathrm{S}$ & \\
\hline $823 \mathrm{~A}-7 \mathrm{H}-2$ & 56 & 73 & 55.53 & 0.59 & 1.7 & VF & silt/VF & & $\Omega$ nm…SS & $\mathrm{T}$ in $\mathrm{S}$ & ? \\
\hline $823 \mathrm{~A}-7 \mathrm{H}-2$ & 0 & 110 & 55.9 & 0.59 & 110 & & & & $\mathbb{I N} \Omega$ & $S$ & \\
\hline $823 \mathrm{~A}-7 \mathrm{H}-2$ & 114 & 115 & 55.95 & 0.59 & 0.5 & silt/VF & silt & & мm… & $\mathrm{T}$ & \\
\hline $823 \mathrm{~A}-7 \mathrm{H}-2$ & 135 & 136 & 56.16 & 0.59 & 0.4 & F & VF/silt & & $m m \cdots$ & $\mathrm{T}$ & \\
\hline $823 \mathrm{~A}-7 \mathrm{H}-4$ & 19 & 20 & 58 & 0.6 & 0.6 & VF & silt & & mm...SS & $T$ & \\
\hline $823 \mathrm{~A}-7 \mathrm{H}-4$ & 68 & 127 & 59.07 & 0.62 & 57.8 & F & VF & & $m$ m...ms & $\mathrm{T}$ to $\mathrm{DF}$ & \\
\hline $823 \mathrm{~A}-7 \mathrm{H}-4$ & 133 & 136 & 59.16 & 0.62 & 2 & VF & silt & & & $\mathrm{T}$ & \\
\hline $823 \mathrm{~A}-7 \mathrm{H}-5$ & 91 & 93 & 60.23 & 0.63 & 1.2 & VF & VF/silt & & IN & $\mathrm{T}$ in $\mathrm{S}$ & ? \\
\hline $823 \mathrm{~A}-7 \mathrm{H}-5$ & 10 & 138 & 60.68 & 0.64 & 0.2 & VF & VF/silt & & IN m $\stackrel{\cdots}{ }$ & $\mathrm{T}$ in $\mathrm{S}$ & ? \\
\hline $823 \mathrm{~A}-7 \mathrm{H}-5$ & 0 & 150 & 60.8 & 0.64 & 150 & & & & IN & $\mathrm{S} / 2$ & ? \\
\hline
\end{tabular}


Appendix A (continued).

\begin{tabular}{|c|c|c|c|c|c|c|c|c|c|c|c|}
\hline Sample & Top $(\mathrm{cm})$ & $\begin{array}{c}\text { Bottom } \\
(\mathrm{cm})\end{array}$ & Depth (m) & $\begin{array}{l}\text { Age } \\
\text { (ma) }\end{array}$ & Thickness (cm) & Texture Base & Texture Top & Mud cap & $\begin{array}{l}\text { Sedimentary } \\
\text { Structure }\end{array}$ & $\begin{array}{l}\text { Depositional } \\
\text { Mechanism }\end{array}$ & $?$ \\
\hline $823 \mathrm{~A}-7 \mathrm{H}-6$ & 68 & 86 & 61.66 & 0.65 & 0.2 & VF & silt & & IN min …SS & $\mathrm{T}$ in $\mathrm{S}$ & $?$ \\
\hline $823 \mathrm{~A}-7 \mathrm{H}-6$ & 136 & 140 & 62.2 & 0.66 & 1.4 & $\mathrm{~F}$ & VF/silt & & IN m $\ldots$... SS & $\mathrm{T}$ in $\mathrm{S}$ & $?$ \\
\hline $823 \mathrm{~A}-7 \mathrm{H}-6$ & 139 & 143 & 62.23 & 0.66 & 0.4 & $\mathrm{~F}$ & VF/silt & & IN m & $T$ in $S$ & ? \\
\hline $823 \mathrm{~A}-7 \mathrm{H}-6$ & 0 & 150 & 62.3 & 0.66 & 150 & & & & IN & $\mathrm{S} / 2$ & ? \\
\hline $823 \mathrm{~A}-7 \mathrm{H}-7$ & 0 & 58 & 62.88 & 0.67 & 58 & & & & $\Omega \mathbb{N}$ & $\mathrm{s} / 2$ & \\
\hline $823 \mathrm{~A}-7 \mathrm{H}-0$ & 0 & 37 & 63.25 & 0.68 & 37 & mud & mud & & $\Omega \mathbb{N}$ & $\mathrm{S} / 2$ & \\
\hline $823 \mathrm{~A}-8 \mathrm{H}-1$ & 0 & 150 & 64.3 & 0.69 & 150 & mud & $\mathrm{F} / \mathrm{M}$ & & $\mathbb{I N} \Omega$ & $\mathrm{S} / 2$ & \\
\hline $823 \mathrm{~A}-8 \mathrm{H}-2$ & 0 & 127 & 65.57 & 0.71 & 0.3 & & & & & $T$ in $S$ & \\
\hline $823 \mathrm{~A}-8 \mathrm{H}-2$ & 127 & 130 & 65.6 & 0.71 & 0.7 & VF & VF/silt & & IN m $\stackrel{\cdots}{ }$ & $T$ in $S$ & \\
\hline $823 \mathrm{~A}-8 \mathrm{H}-2$ & 130 & 145 & 65.75 & 0.71 & 0.5 & mud & VF & & IN $m$ m & $\mathrm{T}$ in $\mathrm{S}$ & \\
\hline $823 \mathrm{~A}-8 \mathrm{H}-2$ & 0 & 150 & 65.8 & 0.72 & 150 & mud & VF & & $\mathbb{I N} \Omega$ & $\mathrm{S} / 2$ & \\
\hline $823 \mathrm{~A}-8 \mathrm{H}-3$ & 0 & 150 & 67.3 & 0.74 & 150 & mud & $\mathrm{F} / \mathrm{M}$ & & $\mathbb{N} \Omega$ & $\mathrm{S} / 2$ & \\
\hline $823 \mathrm{~A}-8 \mathrm{H}-4$ & 0 & 6 & 67.36 & 0.74 & 4.9 & $\mathrm{~F}$ & VF/silt & & мим $\cdots=$ & $T$ in $S$ & $?$ \\
\hline $823 \mathrm{~A}-8 \mathrm{H}-4$ & 27 & 36 & 67.66 & 0.74 & 0.1 & $\mathrm{VF} / \mathrm{F}$ & VF/silt & & mm‥ & $\mathrm{T}$ in $\mathrm{S}$ & $?$ \\
\hline $823 \mathrm{~A}-8 \mathrm{H}-4$ & 36 & 38 & 67.68 & 0.74 & 1.4 & $\mathrm{VF} / \mathrm{F}$ & VF/silt & & $\operatorname{sm} \cdots$ & $\mathrm{T}$ in $\mathrm{S}$ & $?$ \\
\hline $823 \mathrm{~A}-8 \mathrm{H}-4$ & 40 & 41 & 67.71 & 0.74 & 1.4 & VF & VF/silt & & $m m \cdots$ & $\mathrm{T}$ in $\mathrm{S}$ & $?$ \\
\hline $823 \mathrm{~A}-8 \mathrm{H}-4$ & 44 & 46 & 67.76 & 0.74 & 1 & vC & VF & & $m \cdots$ & $\mathrm{T}$ in $\mathrm{S}$ & ? \\
\hline $823 \mathrm{~A}-8 \mathrm{H}-4$ & 62 & 63 & 67.93 & 0.75 & 1.5 & $\mathrm{~F}$ & VF/silt & & мm… & $\mathrm{T}$ in $\mathrm{S}$ & ? \\
\hline $823 \mathrm{~A}-8 \mathrm{H}-4$ & 74 & 76 & 68.06 & 0.75 & 1.2 & VF & VF/silt & & мm… & $T$ in $S$ & $?$ \\
\hline $823 \mathrm{~A}-8 \mathrm{H}-4$ & 78 & 79 & 68.09 & 0.75 & 1.1 & VF & VF/silt & & мnм.. & $\mathrm{T}$ in $\mathrm{S}$ & ? \\
\hline $823 \mathrm{~A}-8 \mathrm{H}-4$ & 98 & 99 & 68.29 & 0.75 & 0.6 & VF & VF/silt & & IN $m$ м $\cdots$ & $\mathrm{T}$ in $\mathrm{S}$ & ? \\
\hline $823 \mathrm{~A}-8 \mathrm{H}-4$ & 0 & 150 & 68.8 & 0.76 & 150 & mud & $\mathrm{VF}(\mathrm{F}-\mathrm{VC})$ & & $\mathbb{I N} \Omega m_{n} \ldots$ & $\mathrm{S} / 2$ & ? \\
\hline $823 \mathrm{~A}-8 \mathrm{H}-5$ & 9 & 10 & 68.9 & 0.76 & 0.2 & $\mathrm{VF}(\mathrm{M})$ & & & & $\mathrm{T}$ in $\mathrm{S}$ & ? \\
\hline $823 \mathrm{~A}-8 \mathrm{H}-5$ & 0 & 150 & 70.3 & 0.78 & 150 & & & & IN & $\mathrm{S} / 2$ & ? \\
\hline $823 \mathrm{~A}-8 \mathrm{H}-6$ & 137 & 138 & 71.68 & 0.8 & 0.8 & VF & VF/silt & & 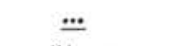 & $\mathrm{T}$ in $\mathrm{S}$ & \\
\hline $823 \mathrm{~A}-8 \mathrm{H}-6$ & 0 & 150 & 71.8 & 0.8 & 150 & & & & $\mathbb{N} \Omega$ & $\mathrm{S} / 2$ & \\
\hline $823 \mathrm{~A}-8 \mathrm{H}-7$ & 24 & 26 & 72.06 & 0.81 & 1.3 & VF & mud & & IN m & $T$ in $S$ & \\
\hline $823 \mathrm{~A}-8 \mathrm{H}-7$ & 48 & 50 & 72.3 & 0.81 & 1.3 & VF & mud & & IN m & $\mathrm{T}$ in $\mathrm{S}$ & \\
\hline $823 \mathrm{~A}-8 \mathrm{H}-7$ & 0 & 57 & 72.37 & 0.81 & 57 & & & & $\mathbb{I N} \Omega$ OT & $\mathrm{s} / 2$ & \\
\hline $823 \mathrm{~A}-8 \mathrm{H}-0$ & 0 & 16 & 72.4 & 0.81 & 16 & mud & silt & & $\mathbb{N} \Omega$ & $\mathrm{s} / 2$ & \\
\hline $823 \mathrm{~A}-8 \mathrm{H}-0$ & 0 & 26 & 72.66 & 0.82 & 26 & & & & мм… & $\mathrm{S} / 2$ & ? \\
\hline $823 \mathrm{~A}-8 \mathrm{H}-0$ & 16 & 26 & 72.66 & 0.82 & 0.1 & & & & мм… & $T$ in $S$ & ? \\
\hline $823 \mathrm{~A}-9 \mathrm{H}-1$ & 0 & 150 & 73.8 & 0.83 & 150 & silt & VF & mud & IN $m$ m & $\mathrm{S} / 2$ & ? \\
\hline $823 \mathrm{~A}-9 \mathrm{H}-2$ & 9 & 10 & 73.9 & 0.84 & 4 & VF & silt & & IN m $\ldots$...SS & $T$ in $S$ & \\
\hline $823 \mathrm{~A}-9 \mathrm{H}-2$ & 10 & 12 & 73.92 & 0.84 & 0.6 & $\mathrm{VF}$ & silt & & IN m m $\ldots$ SS & $T$ in $S$ & \\
\hline $823 \mathrm{~A}-9 \mathrm{H}-2$ & 11 & 15 & 73.95 & 0.84 & 2.6 & vF & silt & & IN m & $\mathrm{T}$ in $\mathrm{S}$ & \\
\hline $823 \mathrm{~A}-9 \mathrm{H}-2$ & 20 & 21 & 74.01 & 0.84 & 0.5 & VF & silt & & IN m $\ldots$ SS & $\mathrm{T}$ in $\mathrm{S}$ & \\
\hline $823 \mathrm{~A}-9 \mathrm{H}-2$ & 68 & 73 & 74.53 & 0.85 & 1 & VF & silt & & IN m $\cdots$ SS & $\mathrm{T}$ in $\mathrm{S}$ & \\
\hline $823 \mathrm{~A}-9 \mathrm{H}-2$ & 0 & 150 & 75.3 & 0.86 & 150 & silt/VF & mud & & IN m m $\ldots$ SS & $\mathrm{S} / 2$ & ? \\
\hline $823 \mathrm{~A}-9 \mathrm{H}-3$ & 0 & 150 & 76.8 & 0.88 & 150 & mud & VF & & IN & $\mathrm{S} / 2$ & ? \\
\hline $823 \mathrm{~A}-9 \mathrm{H}-4$ & 3 & 8 & 76.88 & 0.88 & 0.2 & $\mathrm{VF} / \mathrm{F}$ & silt/VF & & IN $\ldots$ & $T$ in $S$ & ? \\
\hline $823 \mathrm{~A}-9 \mathrm{H}-4$ & 8 & 17 & 76.97 & 0.88 & 7.2 & $\mathrm{VF} /$ silt & silt/VF & & IN $\quad \ldots$ & $T$ in $S$ & ? \\
\hline $823 \mathrm{~A}-9 \mathrm{H}-4$ & 0 & 150 & 78.3 & 0.9 & 150 & & & & IN $\ldots$ & $\mathrm{S} / 2$ & \\
\hline $823 \mathrm{~A}-9 \mathrm{H}-4$ & 20 & 125 & 78.32 & 0.9 & 105 & VF/silt & silt/VF & & IN $\cong$ & $\mathrm{S} / 2$ & ? \\
\hline $823 \mathrm{~A}-9 \mathrm{H}-5$ & 37 & 39 & 78.69 & 0.91 & 0.7 & VF & VF/silt & & IN $\ldots$ & $\mathrm{T}$ in $\mathrm{S}$ & \\
\hline $823 \mathrm{~A}-9 \mathrm{H}-5$ & 0 & 84 & 79.14 & 0.91 & 0.3 & & & & IN $\ldots$ & $\mathrm{T}$ in $\mathrm{S}$ & \\
\hline $823 \mathrm{~A}-9 \mathrm{H}-5$ & 0 & 84 & 79.14 & 0.91 & 84 & & & & IN $\ldots$ & $\mathrm{s} / 2$ & \\
\hline $823 \mathrm{~A}-9 \mathrm{H}-5$ & 0 & 84 & 79.14 & 0.91 & 2002 & mud & VF & & IN & $\mathrm{s}$ & ? \\
\hline $823 \mathrm{~A}-9 \mathrm{H}-5$ & 102 & 104 & 79.34 & 0.92 & 0.2 & VF/silt & mud & & мм… & $\mathrm{T}$ & \\
\hline $823 \mathrm{~A}-9 \mathrm{H}-6$ & 87 & 89 & 80.69 & 0.94 & 2.2 & F & VF/silt & & мm․․S & $\mathrm{T}$ & \\
\hline $823 \mathrm{~A}-9 \mathrm{H}-6$ & 90 & 95 & 80.75 & 0.94 & 5.4 & $\mathrm{~F}$ & VF/silt & & мm․․S & $\mathrm{T}$ & \\
\hline $823 \mathrm{~A}-9 \mathrm{H}-6$ & 95 & 96 & 80.76 & 0.94 & 0.4 & $\mathrm{VF}$ & VF/silt & & mm...SS & $\mathrm{T}$ & \\
\hline $823 \mathrm{~A}-9 \mathrm{H}-6$ & 103 & 106 & 80.86 & 0.94 & 2 & $F / V F$ & VF/silt & & mm…SS & $\mathrm{T}$ & \\
\hline $823 \mathrm{~A}-9 \mathrm{H}-6$ & 138 & 145 & 81.25 & 0.94 & 6.5 & $\mathrm{~F}$ & VF/silt & & 스르sS & $\mathrm{T}$ & \\
\hline $823 \mathrm{~A}-9 \mathrm{H}-7$ & 43 & 48 & 81.78 & 0.95 & 4.5 & VF & VF/silt & & mm...SS & $\mathrm{T}$ & \\
\hline $823 \mathrm{~A}-9 \mathrm{H}-7$ & 58 & 59 & 81.89 & 0.95 & 1.1 & VF & $\mathrm{VF} /$ silt & & mm...SS & $T$ & \\
\hline $823 \mathrm{~A}-10 \mathrm{H}-2$ & 44 & 45 & 83.75 & 0.97 & 0.7 & VF & VF/silt & & $m \ddot{m}=5 S=$ & $\mathrm{T}$ & \\
\hline $823 \mathrm{~A}-10 \mathrm{H}-2$ & 53 & 54 & 83.89 & 0.97 & 0.4 & VF & VF/silt & & $\operatorname{mn} \cdots S S=$ & $\mathrm{T}$ & \\
\hline $823 \mathrm{~A}-10 \mathrm{H}-1$ & 113 & 114 & 83.94 & 0.96 & 0.5 & VF & VF/silt & & mm…SS & $\mathrm{T}$ & \\
\hline $823 \mathrm{~A}-10 \mathrm{H}-2$ & 122 & 172 & 85.02 & 0.98 & 0.8 & VF & VF/silt & & $\operatorname{sm} \cdots=S S$ & $T$ & ? \\
\hline $823 \mathrm{~A}-10 \mathrm{H}-3$ & 58 & 59 & 85.39 & 0.99 & 1.1 & VF & $\mathrm{F} / \mathrm{M}$ & & mm $\cdots 5 S$ & $\mathrm{~T}$ & \\
\hline $823 \mathrm{~A}-10 \mathrm{H}-3$ & 59 & 150 & 86.3 & 1 & 91.3 & mud & $7 \mathrm{~cm}$ & & $\Omega \mathbb{I N C S B U}$ & $\mathrm{DF}$ to $\mathrm{S} / 2$ & \\
\hline $823 \mathrm{~A}-10 \mathrm{H}-4$ & 0 & 150 & 87.8 & 1.01 & 150 & mud & $\mathrm{F} / \mathrm{M}$ & & $I N \Omega m m$...SS & $\mathrm{S} / 2$ & \\
\hline $823 \mathrm{~A}-10 \mathrm{H}-6$ & 0 & 77 & 90.07 & 1.04 & 8.5 & $\mathrm{~F}$ & VF/silt & & IN m m …SS & $\mathrm{T}$ in $\mathrm{S}$ & \\
\hline
\end{tabular}


Appendix A (continued).

\begin{tabular}{|c|c|c|c|c|c|c|c|c|c|c|c|}
\hline Sample & Top $(\mathrm{cm})$ & $\begin{array}{c}\text { Bottom } \\
\text { (cm) }\end{array}$ & Depth (m) & $\begin{array}{c}\text { Age } \\
(\mathrm{ma})\end{array}$ & Thickness (cm) & Texture Base & Texture Top & Mud cap & $\begin{array}{c}\text { Sedimentary } \\
\text { Structure }\end{array}$ & $\begin{array}{l}\text { Depositional } \\
\text { Mechanism }\end{array}$ & ? \\
\hline $823 \mathrm{~A}-10 \mathrm{H}-7$ & 0 & 65 & 91.45 & 1.06 & 65 & mud & $4.0 \mathrm{~cm}$ & & mSBU & $\mathrm{S}$ or $\mathrm{DF} / 2$ & ? \\
\hline $823 \mathrm{~A}-10 \mathrm{H}-7$ & 52 & 65 & 91.45 & 1.06 & 1.2 & $\mathrm{~F}$ & VF & & $\mathbb{I N} \Omega m \underline{\cdots}$ & $\mathrm{T}$ in $\mathrm{DF}$ & ? \\
\hline $823 \mathrm{~A}-10 \mathrm{H}-0$ & 1 & 2 & 91.47 & 1.06 & 0.5 & F & VF & & mm...SS & $\mathrm{T}$ in $\mathrm{S}$ & \\
\hline $823 \mathrm{~A}-10 \mathrm{H}-0$ & 5 & 8 & 91.53 & 1.06 & 0.6 & $\mathrm{~F}$ & VF & & mn…SS & $\mathrm{T}$ in $\mathrm{S}$ & ? \\
\hline $823 \mathrm{~A}-10 \mathrm{H}-0$ & 9 & 14 & 91.59 & 1.06 & 4.6 & $\mathrm{~F} / \mathrm{M}$ & VF & & & $\mathrm{T}$ in $\mathrm{S}$ & ? \\
\hline $823 \mathrm{~A}-10 \mathrm{H}-0$ & 14 & 18 & 91.63 & 1.06 & 3 & $\mathrm{~F} / \mathrm{M}$ & VF & & mm…SS & $\mathrm{T}$ in $\mathrm{S}$ & $?$ \\
\hline $823 \mathrm{~A}-10 \mathrm{H}-0$ & 0 & 18 & 91.63 & 1.06 & 18 & $\mathrm{~F} / \mathrm{M}$ & VF & & min...SS & $D F$ to $S / 2$ & ? \\
\hline $823 \mathrm{~A}-10 \mathrm{H}-0$ & 14 & 18 & 91.63 & 1.06 & 624 & $\mathrm{~F} / \mathrm{M}$ & VF & & mm...SS & $\mathrm{s}$ & ? \\
\hline $823 \mathrm{~A}-11 \mathrm{H}-1$ & 62 & 65 & 91.95 & 1.06 & 3 & $\mathrm{~F} / \mathrm{M}$ & VF & & mm…SS & $\mathrm{T}$ & \\
\hline $823 \mathrm{~A}-11 \mathrm{H}-1$ & 112 & 123 & 92.53 & 1.07 & 10.6 & $\mathrm{~F} / \mathrm{M}$ & VF & & мm… & $\mathrm{T}$ & \\
\hline $823 \mathrm{~A}-11 \mathrm{H}-1$ & 123 & 127 & 92.57 & 1.07 & 4.8 & VF & mud & & mm...SS & $\mathrm{T}$ & \\
\hline $823 \mathrm{~A}-11 \mathrm{H}-1$ & 138 & 140 & 92.7 & 1.07 & 1.5 & $\mathrm{~F}$ & VF/silt & & mm…SS & $\mathrm{T}$ & \\
\hline $823 \mathrm{~A}-11 \mathrm{H}-1$ & 140 & 143 & 92.73 & 1.07 & 1.1 & $\mathrm{~F}$ & VF & & мmㅡ.. & $\mathrm{T}$ & \\
\hline $823 \mathrm{~A}-11 \mathrm{H}-1$ & 148 & 150 & 92.8 & 1.07 & 1.5 & F & VF & & $\ldots$ & $\mathrm{T}$ & \\
\hline $823 \mathrm{~A}-11 \mathrm{H}-2$ & 0 & 7 & 92.87 & 1.07 & 5.8 & $\mathrm{~F}$ & mud & & $\Omega$ & $\mathrm{T}$ & \\
\hline $823 \mathrm{~A}-11 \mathrm{H}-2$ & 7 & 12 & 92.92 & 1.07 & 4.7 & $\mathrm{~F}$ & VF/silt & & mm…SS & $\mathrm{T}$ in $\mathrm{S}$ & $?$ \\
\hline $823 \mathrm{~A}-11 \mathrm{H}-2$ & 12 & 13 & 92.93 & 1.07 & 0.5 & $\mathrm{~F}$ & $\mathrm{VF} / \mathrm{silt}$ & & IN m $\ldots$ SS & $\mathrm{T}$ in $\mathrm{S}$ & $?$ \\
\hline $823 \mathrm{~A}-11 \mathrm{H}-2$ & 15 & 21 & 93.01 & 1.07 & 6.1 & $\mathrm{~F}$ & $\mathrm{VF} /$ silt & & IN m m ...SS & $\mathrm{T}$ in $\mathrm{S}$ & $?$ \\
\hline $823 \mathrm{~A}-11 \mathrm{H}-2$ & 43 & 150 & 94.3 & 1.09 & 107 & mud & F & & $\mathbb{I N} \Omega m \ldots S S$ & $\mathrm{~S} / 2$ & \\
\hline $823 \mathrm{~A}-11 \mathrm{H}-3$ & 0 & 6 & 94.36 & 1.09 & 3 & $\mathrm{~F}$ & & & мn… & $\mathrm{T}$ in $\mathrm{S}$ & \\
\hline $823 \mathrm{~A}-11 \mathrm{H}-3$ & 8 & 16 & 94.46 & 1.09 & 1.8 & $\mathrm{~F}$ & VF/silt & & mm…SS & $\mathrm{T}$ in $\mathrm{S}$ & \\
\hline $823 \mathrm{~A}-11 \mathrm{H}-3$ & 0 & 16 & 94.46 & 1.09 & 16 & & & & IN & $\mathrm{S} / 2$ & ? \\
\hline $823 \mathrm{~A}-11 \mathrm{H}-3$ & 0 & 16 & 94.46 & 1.09 & 123 & & & & IN & $s$ & ? \\
\hline $823 \mathrm{~A}-11 \mathrm{H}-3$ & 21 & 81 & 95.11 & 1.1 & 59.8 & $\mathrm{~F} / \mathrm{M}$ & VF/silt & & mm...SS & $\mathrm{T}$ & \\
\hline $823 \mathrm{~A}-11 \mathrm{H}-3$ & 99 & 100 & 95.3 & 1.1 & 0.6 & $\mathrm{~F}$ & silt & & мn…SS & $\mathrm{T}$ & \\
\hline $823 \mathrm{~A}-11 \mathrm{H}-3$ & 126 & 150 & 95.7 & 1.1 & 23.5 & mud & $2.4 \mathrm{~cm}$ & & $\mathrm{~ms} \bumpeq \mathrm{CS}$ & $\mathrm{DF} / 2$ & \\
\hline $823 \mathrm{~A}-11 \mathrm{H}-4$ & 57 & 139 & 97.19 & 1.13 & 82 & mud & $4 \mathrm{~cm}$ & & $\mathrm{~ms} \Omega$ & $\mathrm{DF} / 2$ & \\
\hline $823 \mathrm{~A}-11 \mathrm{H}-4$ & 0 & 150 & 97.3 & 1.13 & 150 & mud & $15 \mathrm{~cm}$ & & $\mathrm{~ms} \Omega$ & $\mathrm{DF} / 2$ & \\
\hline $823 \mathrm{~A}-11 \mathrm{H}-4$ & 0 & 150 & 97.3 & 1.13 & 173.5 & mud & & & $\mathrm{ms} \Omega$ & DF & \\
\hline $823 \mathrm{~A}-11 \mathrm{H}-5$ & 15 & 18 & 97.48 & 1.13 & 3 & VF & VF/silt & mud & SS & $\mathrm{T}$ & ? \\
\hline $823 \mathrm{~A}-11 \mathrm{H}-5$ & 122 & 127 & 98.57 & 1.15 & 2 & VF & VF/silt & & mm…SS & $\mathrm{T}$ & \\
\hline $823 \mathrm{~A}-11 \mathrm{H}-6$ & 4 & 6 & 98.86 & 1.16 & 1.5 & VF & VF/silt & & мn…SS & $\mathrm{T}$ & \\
\hline $823 \mathrm{~A}-11 \mathrm{H}-6$ & 30 & 31 & 99.11 & 1.16 & 1.1 & VF & $\mathrm{VF} / \mathrm{silt}$ & & & $T$ & \\
\hline $823 \mathrm{~A}-11 \mathrm{H}-6$ & 72 & 73 & 99.53 & 1.17 & 0.8 & VF & $\mathrm{VF} / \mathrm{silt}$ & & ...SSS & $\mathrm{T}$ & \\
\hline $823 \mathrm{~A}-11 \mathrm{H}-6$ & 103 & 104 & 99.84 & 1.17 & 1 & VF & VF/silt & & ...SS & $T$ & \\
\hline $823 \mathrm{~A}-11 \mathrm{H}-6$ & 115 & 116 & 99.96 & 1.17 & 0.5 & VF & VF/silt & & $\ldots$ & $T$ & \\
\hline $823 \mathrm{~A}-11 \mathrm{H}-7$ & 19 & 20 & 100.5 & 1.18 & 0.7 & VF & VF/silt & & $\underline{\ldots}$ & $T$ & \\
\hline $823 \mathrm{~A}-12 \mathrm{H}-1$ & 14 & 15 & 101 & 1.19 & 0.2 & VF & silt & & mu…SS & $T$ & \\
\hline $823 \mathrm{~A}-12 \mathrm{H}-1$ & 31 & 32 & 101.1 & 1.19 & 0.3 & VF & silt & & mn…SS & $\mathrm{T}$ & \\
\hline $823 \mathrm{~A}-12 \mathrm{H}-1$ & 67 & 68 & 101.5 & 1.2 & 0.7 & VF & silt & & mu…SS & $\mathrm{T}$ & \\
\hline $823 \mathrm{~A}-12 \mathrm{H}-1$ & 121 & 122 & 102 & 1.21 & 1 & VF & silt & & mm…SS & $\mathrm{T}$ & \\
\hline $823 \mathrm{~A}-12 \mathrm{H}-2$ & 10 & 11 & 102.4 & 1.22 & 0.3 & VF & silt & & & $\mathrm{T}$ & \\
\hline $823 \mathrm{~A}-12 \mathrm{H}-2$ & 42 & 43 & 102.7 & 1.22 & 0.7 & VF & VF/silt & & mm…SS & $\mathrm{T}$ & \\
\hline $823 \mathrm{~A}-12 \mathrm{H}-2$ & 43 & 111 & 103.4 & 1.23 & 68 & mud & $1.5 \mathrm{~cm}$ & & $\sim B V$ & DF or $\mathrm{S}$ & ? \\
\hline $823 \mathrm{~A}-12 \mathrm{H}-2$ & 111 & 114 & 103.4 & 1.23 & 0.4 & $\mathrm{~F}$ & $\mathrm{VF} /$ silt & & mm…SS & $\mathrm{T}$ & \\
\hline $823 \mathrm{~A}-12 \mathrm{H}-2$ & 115 & 120 & 103.5 & 1.23 & 4.5 & $\mathrm{~F} / \mathrm{M}$ & VF/silt & & mm…SS & $\mathrm{T}$ & \\
\hline $823 \mathrm{~A}-12 \mathrm{H}-2$ & 128 & 133 & 103.6 & 1.24 & 5 & $\mathrm{~F}$ & VF/silt & & mm…SS & $T$ & \\
\hline $823 \mathrm{~A}-12 \mathrm{H}-2$ & 137 & 141 & 103.7 & 1.24 & 3 & F & VF/silt & & ми…SS & $T$ & \\
\hline $823 \mathrm{~A}-12 \mathrm{H}-3$ & 58 & 61 & 104.4 & 1.25 & 4.3 & $\mathrm{~F}$ & silt & & mm…SS & $T$ & \\
\hline $823 \mathrm{~A}-12 \mathrm{H}-3$ & 62 & 65 & 104.5 & 1.25 & 2.6 & F & silt & & ми…SS & $T$ & \\
\hline $823 \mathrm{~A}-12 \mathrm{H}-3$ & 102 & 103 & 104.8 & 1.26 & 0.4 & $\mathrm{~F}$ & silt & & mm...SS & $T$ & \\
\hline $823 \mathrm{~A}-12 \mathrm{H}-6$ & 0 & 5 & 108.4 & 1.28 & 3.7 & M & F & & ми… & $T$ & \\
\hline $823 \mathrm{~A}-12 \mathrm{H}-6$ & 8 & 20 & 108.5 & 1.28 & 13 & $\mathrm{~F} / \mathrm{M}(\mathrm{C})$ & VF/silt & & $m m \cdots=S S$ & $\mathrm{~T}$ & \\
\hline $823 \mathrm{~A}-12 \mathrm{H}-6$ & 39 & 48 & 108.8 & 1.28 & 7.2 & $\mathrm{~F} / \mathrm{M}$ & VF/silt & & $m m \cdots=S S$ & $T$ & \\
\hline $823 \mathrm{~A}-12 \mathrm{H}-6$ & 49 & 54 & 108.8 & 1.28 & 5 & $\mathrm{~F}$ & $\mathrm{VF} /$ silt & & $\operatorname{sm} \cdots=S S$ & $\mathrm{~T}$ & \\
\hline $823 \mathrm{~A}-12 \mathrm{H}-6$ & 67 & 72 & 109 & 1.29 & 4.6 & $\mathrm{~F} / \mathrm{M}$ & VF/silt & & $m m \cdots=S S$ & $\mathrm{~T}$ & \\
\hline $823 \mathrm{~A}-12 \mathrm{H}-6$ & 74 & 75 & 109.1 & 1.29 & 0.8 & $\mathrm{~F}$ & VF/silt & & mu…SS & $T$ & \\
\hline $823 \mathrm{~A}-12 \mathrm{H}-6$ & 111 & 116 & 109.5 & 1.29 & 4.2 & $\mathrm{~F}$ & VF/silt & & mu…SS & $\mathrm{T}$ & \\
\hline $823 \mathrm{~A}-12 \mathrm{H}-6$ & 124 & 126 & 109.6 & 1.29 & 0.8 & VF & $\mathrm{VF} /$ silt & & m…SS & $T$ & \\
\hline $823 \mathrm{~A}-12 \mathrm{H}-6$ & 132 & 134 & 109.6 & 1.29 & 1.4 & $\mathrm{~F}$ & VF/silt & & mu…SS & $T$ & \\
\hline $823 \mathrm{~A}-12 \mathrm{H}-6$ & 148 & 150 & 109.8 & 1.29 & 1.3 & VF & VF/silt & & ...SS & $T$ & \\
\hline $823 \mathrm{~A}-12 \mathrm{H}-7$ & 12 & 13 & 109.9 & 1.29 & 1 & $\mathrm{~F}$ & VF/silt & & mm...SS & $\mathrm{T}$ & \\
\hline $823 \mathrm{~A}-12 \mathrm{H}-7$ & 31 & 34 & 110.1 & 1.29 & 2.5 & VF & VF/silt & & 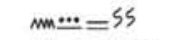 & $T$ & \\
\hline $823 \mathrm{~A}-12 \mathrm{H}-7$ & 50 & 53 & 110.3 & 1.29 & 0.8 & $\mathrm{~F}$ & VF/silt & & IN m $\ldots$...SS & $\mathrm{T}$ & \\
\hline
\end{tabular}


Appendix A (continued).

\begin{tabular}{|c|c|c|c|c|c|c|c|c|c|c|c|}
\hline Sample & Top $(\mathrm{cm})$ & $\begin{array}{c}\text { Bottom } \\
(\mathrm{cm})\end{array}$ & Depth (m) & $\begin{array}{l}\text { Age } \\
\text { (ma) }\end{array}$ & Thickness (cm) & Texture Base & Texture Top & Mud cap & $\begin{array}{c}\text { Sedimentary } \\
\text { Structure }\end{array}$ & $\begin{array}{l}\text { Depositional } \\
\text { Mechanism }\end{array}$ & $?$ \\
\hline $823 \mathrm{~A}-13 \mathrm{H}-1$ & 5 & 12 & 110.4 & 1.29 & 4.2 & $\mathrm{VF} / \mathrm{F}$ & VF/silt & & IN m m …SS & $\mathrm{T}$ & \\
\hline $823 \mathrm{~A}-13 \mathrm{H}-1$ & 15 & 17 & 110.5 & 1.29 & 1 & $\mathrm{VF} / \mathrm{F}$ & VF/silt & & IN $\mathrm{Nm} \ldots$.. SS & $\mathrm{T}$ & \\
\hline $823 \mathrm{~A}-13 \mathrm{H}-1$ & 17 & 24 & 110.5 & 1.29 & 6.4 & $\mathrm{~F} / \mathrm{M}$ & VF/silt & & IN $\mathrm{mm} \ldots \mathrm{KS}$ & $\mathrm{T}$ & \\
\hline $823 \mathrm{~A}-13 \mathrm{H}-1$ & 24 & 28 & 110.6 & 1.29 & 2.5 & $\mathrm{~F} / \mathrm{M}$ & VF/silt & & mm...SS & $\mathrm{T}$ & \\
\hline $823 \mathrm{~A}-13 \mathrm{H}-1$ & 34 & 41 & 110.7 & 1.29 & 6 & $\mathrm{~F}$ & VF/silt & & $1 \mathrm{~N} m \ldots S$ & T & \\
\hline $823 \mathrm{~A}-13 \mathrm{H}-1$ & 41 & 45 & 110.8 & 1.29 & 1.4 & F & VF/silt & & IN $\mathrm{mm} \ldots S S$ & $\mathrm{~T}$ & \\
\hline $823 \mathrm{~A}-13 \mathrm{H}-1$ & 48 & 53 & 110.8 & 1.29 & 5 & VF & VF/silt & mud & sm…=SS & $\mathrm{T}$ & \\
\hline $823 \mathrm{~A}-13 \mathrm{H}-1$ & 56 & 62 & 110.9 & 1.29 & 5 & VF & mud & & SS & $\mathrm{T}$ & \\
\hline $823 \mathrm{~A}-13 \mathrm{H}-1$ & 62 & 64 & 110.9 & 1.29 & 1.1 & & & & muss & $\mathrm{T}$ & \\
\hline $823 \mathrm{~A}-13 \mathrm{H}-1$ & 64 & 66 & 111 & 1.29 & 1.6 & VF & VF/silt & & & T & \\
\hline $823 \mathrm{~A}-13 \mathrm{H}-1$ & 85 & 88 & 111.2 & 1.3 & 1.3 & VF & VF/silt & & mm…SS & $\mathrm{T}$ & \\
\hline $823 \mathrm{~A}-13 \mathrm{H}-1$ & 91 & 101 & 111.3 & 1.3 & 10 & $\mathrm{~F}$ & VF/silt & & мm프= & $\mathrm{T}$ & \\
\hline $823 \mathrm{~A}-13 \mathrm{H}-1$ & 103 & 104 & 111.3 & 1.3 & 1.1 & VF & VF/silt & & mm...SS & T & \\
\hline $823 \mathrm{~A}-13 \mathrm{H}-1$ & 111 & 117 & 111.5 & 1.3 & 6.5 & $\mathrm{~F} / \mathrm{M}$ & VF/silt & & мm프= $=$ & $\mathrm{T}$ & \\
\hline $823 \mathrm{~A}-13 \mathrm{H}-1$ & 124 & 140 & 111.7 & 1.3 & 15 & $\mathrm{~F}$ & $\mathrm{VF} /$ silt & & IN m m $\cdots S S$ & $T$ in $S$ & ? \\
\hline $823 \mathrm{~A}-13 \mathrm{H}-1$ & 140 & 144 & 111.7 & 1.3 & 4.5 & VF & VF/silt & & nnm...SS & $\mathrm{T}$ & \\
\hline $823 \mathrm{~A}-13 \mathrm{H}-2$ & 0 & 14 & 111.9 & 1.3 & 14 & VF & mud & & ...SS & $\mathrm{T}$ & \\
\hline $823 \mathrm{~A}-13 \mathrm{H}-2$ & 14 & 24 & 112 & 1.3 & 5.7 & VF & VF/silt & & mи…SS & $T$ in $S$ & $?$ \\
\hline $823 \mathrm{~A}-13 \mathrm{H}-2$ & 28 & 38 & 112.2 & 1.3 & 7.3 & $\mathrm{M} / \mathrm{C}$ & VF/silt & & m...SS & $T$ in $S$ & ? \\
\hline $823 \mathrm{~A}-13 \mathrm{H}-2$ & 81 & 87 & 112.7 & 1.3 & 3 & $\mathrm{~F}$ & VF/silt & & mm...SS & $T$ in $S$ & ? \\
\hline $823 \mathrm{~A}-13 \mathrm{H}-2$ & 90 & 94 & 112.7 & 1.3 & 0.8 & VF & VF/silt & & mm...SS & $T$ in $S$ & ? \\
\hline $823 \mathrm{~A}-13 \mathrm{H}-2$ & 97 & 102 & 112.8 & 1.3 & 3.5 & VF & VF/silt & & mm...SS & $T$ in $S$ & ? \\
\hline $823 \mathrm{~A}-13 \mathrm{H}-2$ & 102 & 110 & 112.9 & 1.3 & 5.2 & $\mathrm{M}(\mathrm{C})$ & VF/silt & & ми…SS & $\mathrm{T}$ in $\mathrm{S}$ & ? \\
\hline $823 \mathrm{~A}-13 \mathrm{H}-2$ & 14 & 110 & 112.9 & 1.3 & 96 & $\mathrm{M}(\mathrm{C})$ & VF/silt & & mи…SS & $\mathrm{S}$ & ? \\
\hline $823 \mathrm{~A}-13 \mathrm{H}-2$ & 110 & 111 & 112.9 & 1.3 & 1 & VF & VF/silt & & & $\mathrm{T}$ & \\
\hline $823 \mathrm{~A}-13 \mathrm{H}-2$ & 112 & 122 & 113 & 1.3 & 9.2 & $\mathrm{~F}$ & VF/silt & & мм․ㅡ=SS & $\mathrm{T}$ & \\
\hline $823 \mathrm{~A}-13 \mathrm{H}-2$ & 129 & 130 & 113.1 & 1.3 & 1.5 & $\mathrm{~F}$ & VF/silt & & mm...SS & $\mathrm{T}$ & \\
\hline $823 \mathrm{~A}-13 \mathrm{H}-2$ & 135 & 139 & 113.2 & 1.3 & 4 & F & VF/silt & & ми…SS & $\mathrm{T}$ & \\
\hline $823 \mathrm{~A}-13 \mathrm{H}-3$ & 8 & 73 & 114 & 1.31 & 65 & $\mathrm{M} / \mathrm{F}$ & VF/silt & & ми…SS & $\mathrm{T}$ & \\
\hline $823 \mathrm{~A}-13 \mathrm{H}-3$ & 76 & 149 & 114.8 & 1.31 & 72.8 & $\mathrm{M} / \mathrm{F}$ & VF/silt & & ми…SS & $\mathrm{T}$ & \\
\hline $823 \mathrm{~A}-13 \mathrm{H}-4$ & 47 & 53 & 115.3 & 1.31 & 6.7 & VF & mud & & $m m \cdots=S S$ & $\mathrm{~T}$ & \\
\hline $823 \mathrm{~A}-13 \mathrm{H}-4$ & 67 & 71 & 115.5 & 1.32 & 3.7 & $\mathrm{~F} / \mathrm{M}$ & VF/silt & & mn…SS & $\mathrm{T}$ & \\
\hline $823 \mathrm{~A}-13 \mathrm{H}-4$ & 83 & 85 & 115.7 & 1.32 & 1.8 & $\mathrm{~F}$ & VF/silt & & mn…SS & $\mathrm{T}$ & \\
\hline $823 \mathrm{~A}-13 \mathrm{H}-4$ & 90 & 150 & 116.3 & 1.32 & 58.5 & $\mathrm{~F} / \mathrm{M}$ & VF/silt & & ...SS & $\mathrm{T}$ & \\
\hline $823 \mathrm{~A}-13 \mathrm{H}-5$ & 1 & 4 & 116.3 & 1.32 & 3.5 & $\mathrm{~F} / \mathrm{M}$ & & & мnс… & $\mathrm{T}$ & \\
\hline $823 \mathrm{~A}-13 \mathrm{H}-5$ & 6 & 51 & 116.8 & 1.32 & 44 & $\mathrm{~F} / \mathrm{M}$ & F & & ми…SS & $\mathrm{T}$ & \\
\hline $823 \mathrm{~A}-13 \mathrm{H}-5$ & 55 & 57 & 116.9 & 1.32 & 1 & VF & VF/silt & & ...SS & $\mathrm{T}$ & \\
\hline $823 \mathrm{~A}-13 \mathrm{H}-5$ & 66 & 70 & 117 & 1.32 & 2.8 & $\mathrm{~F}$ & VF/silt & & mi...SS & $\mathrm{T}$ & \\
\hline $823 \mathrm{~A}-13 \mathrm{H}-5$ & 79 & 87 & 117.2 & 1.32 & 7.6 & F & VF/silt & & mm…SS & $T$ & \\
\hline $823 \mathrm{~A}-13 \mathrm{H}-5$ & 96 & 98 & 117.3 & 1.32 & 1.8 & F & VF/silt & & $m m \cdots=S S$ & $\mathrm{~T}$ & \\
\hline $823 \mathrm{~A}-13 \mathrm{H}-5$ & 105 & 107 & 117.4 & 1.32 & 2.1 & $\mathrm{~F}$ & VF/silt & & mm…SS & $\mathrm{T}$ & \\
\hline $823 \mathrm{~A}-13 \mathrm{H}-5$ & 118 & 119 & 117.5 & 1.32 & 0.5 & VF & VF/silt & & sm… & $\mathrm{T}$ & ? \\
\hline $823 \mathrm{~A}-13 \mathrm{H}-5$ & 128 & 131 & 117.6 & 1.33 & 2.6 & $\mathrm{~F}$ & VF & & $\operatorname{sn} \cdots=$ & $\mathrm{T}$ & ? \\
\hline $823 \mathrm{~A}-13 \mathrm{H}-6$ & 13 & 16 & 118 & 1.33 & 2.3 & VF & VF/silt & & & $\mathrm{T}$ & ? \\
\hline $823 \mathrm{~A}-13 \mathrm{H}-6$ & 43 & 47 & 118.3 & 1.33 & 0.5 & VF & VF/silt & & mn… & $T$ & ? \\
\hline $823 \mathrm{~A}-13 \mathrm{H}-6$ & 49 & 53 & 118.3 & 1.33 & 3.3 & $\mathrm{~F} / \mathrm{M}$ & VF/silt & & $m m \cdots=S S$ & $\mathrm{~T}$ & ? \\
\hline $823 \mathrm{~A}-13 \mathrm{H}-6$ & 54 & 56 & 118.4 & 1.33 & 2 & VF & VF/silt & & m플 & $\mathrm{T}$ & ? \\
\hline $823 \mathrm{~A}-13 \mathrm{H}-6$ & 58 & 59 & 118.4 & 1.33 & 0.7 & VF & VF/silt & & мm… & $\mathrm{T}$ & ? \\
\hline $823 \mathrm{~A}-13 \mathrm{H}-6$ & 68 & 79 & 118.6 & 1.33 & 10.5 & $\mathrm{~F}$ & VF & & мм… & $\mathrm{T}$ & ? \\
\hline $823 \mathrm{~A}-13 \mathrm{H}-6$ & 87 & 90 & 118.7 & 1.33 & 2.7 & $\mathrm{~F}$ & VF & & 쓰… & $\mathrm{T}$ & \\
\hline $823 \mathrm{~A}-13 \mathrm{H}-6$ & 101 & 102 & 118.8 & 1.33 & 1 & F & VF & & ми… & $\mathrm{T}$ & ? \\
\hline $823 \mathrm{~A}-13 \mathrm{H}-6$ & 113 & 117 & 119 & 1.33 & 2.7 & $\mathrm{~F}$ & VF & & ми…SS & $T$ & ? \\
\hline $823 \mathrm{~A}-13 \mathrm{H}-6$ & 129 & 142 & 119.2 & 1.33 & 11.8 & $\mathrm{~F}$ & VF & & ми…SS & $\mathrm{T}$ & $?$ \\
\hline $823 \mathrm{~A}-13 \mathrm{H}-7$ & 0 & 22 & 119.5 & 1.33 & 21.6 & $\mathrm{~F} / \mathrm{M}$ & $\mathrm{VF} / \mathrm{F}$ & & ми…SS & $\mathrm{T}$ & ? \\
\hline $823 \mathrm{~A}-13 \mathrm{H}-7$ & 27 & 28 & 119.6 & 1.33 & 1 & $\mathrm{~F}$ & VF & & ми…SS & $T$ & ? \\
\hline $823 \mathrm{~A}-13 \mathrm{H}-7$ & 35 & 57 & 119.9 & 1.34 & 21.5 & $\mathrm{~F} / \mathrm{M}$ & VF & & mи…SS & $\mathrm{T}$ & ? \\
\hline $823 \mathrm{~A}-13 \mathrm{H}-7$ & 65 & 69 & 120 & 1.34 & 4.7 & $\mathrm{~F}$ & VF & & mm‥- & $\mathrm{T}$ & ? \\
\hline $823 \mathrm{~A}-13 \mathrm{H}-0$ & 8 & 10 & 120.2 & 1.34 & 1.6 & $\mathrm{~F}$ & VF & & SS & $\mathrm{T}$ & ? \\
\hline $823 \mathrm{~B}-13 \mathrm{X}-1$ & 0 & 9 & 112.9 & 1.3 & 8.5 & mud & $2 \mathrm{~cm}$ & & CS & DF & ? \\
\hline 823B-13X-1 & 9 & 10 & 112.9 & 1.3 & 1.1 & $\mathrm{~F}$ & VF & & ми…SS & $\mathrm{T}$ & \\
\hline $823 \mathrm{~B}-13 \mathrm{X}-1$ & 19 & 25 & 113.1 & 1.3 & 6.5 & VF & silt/VF & & mm….sS & $T$ & \\
\hline $823 \mathrm{~B}-13 \mathrm{X}-1$ & 43 & 56 & 113.4 & 1.31 & 12.2 & $\mathrm{M}(\mathrm{VC})$ & VF/silt & & mm…SS & $T$ & \\
\hline $823 \mathrm{~B}-13 \mathrm{X}-1$ & 93 & 105 & 113.9 & 1.31 & 12 & $\mathrm{M}$ & VF/silt & & 쓰…SS & $\mathrm{T}$ & \\
\hline $823 \mathrm{~B}-13 \mathrm{X}-1$ & 105 & 126 & 114.1 & 1.31 & 20.7 & F & VF & & ми…SS & $\mathrm{T}$ & \\
\hline
\end{tabular}


Appendix A (continued).

\begin{tabular}{|c|c|c|c|c|c|c|c|c|c|c|}
\hline Sample & Top $(\mathrm{cm})$ & $\begin{array}{c}\text { Bottom } \\
(\mathrm{cm})\end{array}$ & Depth (m) & $\begin{array}{c}\text { Age } \\
\text { (ma) }\end{array}$ & Thickness (cm) & Texture Base & Texture Top Mud cap & $\begin{array}{c}\text { Sedimentary } \\
\text { Structure }\end{array}$ & $\begin{array}{l}\text { Depositional } \\
\text { Mechanism }\end{array}$ & $?$ \\
\hline $823 \mathrm{~B}-13 \mathrm{X}-1$ & 147 & 150 & 114.3 & 1.31 & 3.3 & $\mathrm{M} / \mathrm{F}$ & VF & ...SS & $\mathrm{T}$ & \\
\hline $823 \mathrm{~B}-13 \mathrm{X}-2$ & 0 & 25 & 114.6 & 1.31 & 24 & $\mathrm{~F}$ & & & $\mathrm{~T}$ & \\
\hline $823 \mathrm{~B}-13 \mathrm{X}-2$ & 25 & 49 & 114.8 & 1.31 & 24.3 & M & $\mathrm{VF}$ & $\ldots$ & $T$ & \\
\hline $823 \mathrm{~B}-13 \mathrm{X}-2$ & 49 & 65 & 115 & 1.31 & 16.2 & $\mathrm{~F}$ & VF & $\cdots$ & $\mathrm{T}$ & \\
\hline $823 \mathrm{~B}-13 \mathrm{X}-2$ & 65 & 81 & 115.1 & 1.31 & 15.7 & $\mathrm{~F}$ & VF & $\underline{\cdots}$ & $\mathrm{T}$ & \\
\hline $823 \mathrm{~B}-13 \mathrm{X}-2$ & 81 & 82 & 115.1 & 1.31 & 0.7 & VF & VF/silt & мm… & $\mathrm{T}$ & \\
\hline $823 \mathrm{~B}-13 \mathrm{X}-2$ & 86 & 95 & 115.3 & 1.31 & 9.1 & $\mathrm{M} / \mathrm{C}$ & VF & $m m \cdots=$ & $\mathrm{T}$ & \\
\hline $823 \mathrm{~B}-13 \mathrm{X}-2$ & 112 & 115 & 115.5 & 1.32 & 2.6 & $\mathrm{~F}$ & VF & $\operatorname{sm} \cdots=S S$ & $\mathrm{~T}$ & \\
\hline $823 \mathrm{~B}-13 \mathrm{X}-2$ & 132 & 133 & 115.6 & 1.32 & 1 & F & VF & мn․ㅡ= & $\mathrm{T}$ & \\
\hline $823 \mathrm{~B}-13 \mathrm{X}-3$ & 4 & 7 & 115.9 & 1.32 & 2.9 & F & VF & $\underline{\cdots}=$ & $\mathrm{T}$ & \\
\hline $823 \mathrm{~B}-13 \mathrm{X}-3$ & 13 & 17 & 116 & 1.32 & 3.3 & M & VF/silt & sn $\cdots=S S$ & $\mathrm{~T}$ & \\
\hline $823 \mathrm{~B}-13 \mathrm{X}-3$ & 21 & 28 & 116.1 & 1.32 & 7.3 & C & VF/silt & мм․ㅡ=SS & $\mathrm{T}$ & \\
\hline $823 \mathrm{~B}-13 \mathrm{X}-3$ & 29 & 30 & 116.1 & 1.32 & 1.1 & VF & VF/silt & mи…SS & $\mathrm{T}$ & \\
\hline $823 \mathrm{~B}-13 \mathrm{X}-3$ & 38 & 39 & 116.2 & 1.32 & 0.8 & VF & VF/silt & ми…SS & $\mathrm{T}$ & \\
\hline $823 \mathrm{~B}-13 \mathrm{X}-3$ & 44 & 48 & 116.3 & 1.32 & 4 & $\mathrm{~F} / \mathrm{M}$ & VF/silt & мnㅡㅡS & $\mathrm{T}$ & \\
\hline $823 \mathrm{~B}-13 \mathrm{X}-3$ & 49 & 59 & 116.4 & 1.32 & 4 & $F$ & VF/silt & ми…SS & $\mathrm{T}$ & \\
\hline $823 \mathrm{~B}-13 \mathrm{X}-3$ & 60 & 61 & 116.4 & 1.32 & 0.5 & VF & VF/silt & иㅡ…SS & $\mathrm{T}$ & \\
\hline $823 \mathrm{~B}-13 \mathrm{X}-3$ & 63 & 65 & 116.5 & 1.32 & 1.6 & $\mathrm{~F}$ & VF/silt & & $\mathrm{T}$ & \\
\hline $823 \mathrm{~B}-13 \mathrm{X}-3$ & 78 & 79 & 116.6 & 1.32 & 1.2 & VF & VF/silt & мn…5S & $T$ & \\
\hline $823 \mathrm{~B}-13 \mathrm{X}-3$ & 90 & 91 & 116.7 & 1.32 & 1.3 & VF & VF/silt & 느토s & $\mathrm{T}$ & \\
\hline $823 \mathrm{~B}-13 \mathrm{X}-3$ & 99 & 100 & 116.8 & 1.32 & 0.9 & $\mathrm{VF}$ & VF/silt & мn…SS & $\mathrm{T}$ & \\
\hline $823 \mathrm{~B}-13 \mathrm{X}-3$ & 116 & 119 & 117 & 1.32 & 2.7 & $\mathrm{~F}$ & VF/silt & mㅡㄹ. & $\mathrm{T}$ & \\
\hline $823 \mathrm{~B}-13 \mathrm{X}-3$ & 121 & 135 & 117.2 & 1.32 & 13.7 & $\mathrm{~F} / \mathrm{M}$ & VF/silt & mn…SS & $\mathrm{T}$ & \\
\hline $823 \mathrm{~B}-13 \mathrm{X}-3$ & 138 & 139 & 117.2 & 1.32 & 0.8 & VF & VF/silt & ‥ & $\mathrm{T}$ & \\
\hline $823 \mathrm{~B}-13 \mathrm{X}-4$ & 1 & 16 & 117.5 & 1.32 & 15 & $\mathrm{~F} / \mathrm{M}$ & VF/silt & mи…SS & $\mathrm{T}$ & \\
\hline $823 \mathrm{~B}-13 \mathrm{X}-4$ & 25 & 30 & 117.6 & 1.33 & 5 & $\mathrm{~F}$ & VF/silt & ми…SS & $T$ & \\
\hline $823 \mathrm{~B}-13 \mathrm{X}-4$ & 37 & 38 & 117.7 & 1.33 & 1 & VF & & mи…SS & $\mathrm{T}$ & \\
\hline $823 \mathrm{~B}-13 \mathrm{X}-4$ & 55 & 73 & 118 & 1.33 & 18.5 & $\mathrm{~F} / \mathrm{M}$ & VF/silt & mи…SS & $T$ & \\
\hline $823 \mathrm{~B}-13 \mathrm{X}-4$ & 130 & 133 & 118.6 & 1.33 & 3 & $\mathrm{~F}$ & VF & ми…SS & T & \\
\hline $823 \mathrm{~B}-13 \mathrm{X}-4$ & 144 & 145 & 118.8 & 1.33 & 1.3 & $\mathrm{~F}$ & VF & mn…SS & $\mathrm{T}$ & \\
\hline $823 \mathrm{~B}-13 \mathrm{X}-5$ & 0 & 7 & 118.9 & 1.33 & 6.5 & M & VF & $\operatorname{sn} \cdots=S S$ & T & \\
\hline $823 \mathrm{~B}-13 \mathrm{X}-5$ & 20 & 22 & 119 & 1.33 & 1 & $\mathrm{VF} / \mathrm{F}$ & VF & m…SS & $\mathrm{T}$ & \\
\hline $823 \mathrm{~B}-13 \mathrm{X}-5$ & 48 & 55 & 119.4 & 1.33 & 0 & & & & $\mathrm{~T}$ & \\
\hline $823 \mathrm{~B}-13 \mathrm{X}-5$ & 69 & 74 & 119.5 & 1.33 & 5 & F & VF & ...SS & $\mathrm{T}$ & \\
\hline $823 \mathrm{~B}-13 \mathrm{X}-5$ & 81 & 82 & 119.6 & 1.33 & 1.1 & $\mathrm{~F} / \mathrm{M}$ & VF & ‥SSS & T & \\
\hline $823 \mathrm{~B}-13 \mathrm{X}-5$ & 106 & 112 & 119.9 & 1.34 & 6.8 & $\mathrm{~F}$ & VF & mи…SS & $\mathrm{T}$ & \\
\hline $823 \mathrm{~B}-13 \mathrm{X}-5$ & 143 & 146 & 120.3 & 1.34 & 3 & F & VF/silt & $m n \cdots=S S$ & $T$ & \\
\hline $823 \mathrm{~B}-13 \mathrm{X}-6$ & 17 & 34 & 120.6 & 1.34 & 16.8 & & & mn…mm & $T$ in DF & \\
\hline $823 B-13 X-6$ & 0 & 49 & 120.8 & 1.34 & 49 & mud & $16.8 \mathrm{~cm}$ & CSBV & DF & $?$ \\
\hline $823 \mathrm{~B}-13 \mathrm{X}-6$ & 51 & 61 & 120.9 & 1.34 & 9 & $F$ & VF & ...SS & $\mathrm{T}$ & \\
\hline $823 \mathrm{~B}-13 \mathrm{X}-0$ & 0 & 16 & 121.1 & 1.34 & 16 & VF & $\mathrm{F}$ & & $\mathrm{T}$ & \\
\hline $823 \mathrm{~B}-14 \mathrm{X}-1$ & 8 & 65 & 123.1 & 1.35 & 57 & & & $\Omega$ & $\mathrm{s}$ & \\
\hline 823B-14X-1 & 70 & 72 & 123.1 & 1.35 & 1.9 & F & VF/silt & & $T$ & \\
\hline $823 \mathrm{~B}-14 \mathrm{X}-1$ & 82 & 86 & 123.3 & 1.35 & 4 & F & VF/silt & mm…SS & $\mathrm{T}$ & \\
\hline $823 \mathrm{~B}-14 \mathrm{X}-1$ & 105 & 110 & 123.5 & 1.35 & 4.7 & F & VF/silt & ми…SS & T & \\
\hline $823 \mathrm{~B}-14 \mathrm{X}-1$ & 127 & 132 & 123.7 & 1.35 & 4.5 & F & VF/silt & mnㅡ..SS & $\mathrm{T}$ & \\
\hline $823 \mathrm{~B}-14 \mathrm{X}-1$ & 144 & 146 & 123.9 & 1.35 & 2.2 & VF & VF/silt & ми…SS & $T$ & \\
\hline $823 \mathrm{~B}-14 \mathrm{X}-2$ & 30 & 34 & 124.2 & 1.36 & 4 & silt & $\mathrm{M} / \mathrm{F}$ & $\bar{\cdots}$ & $\mathrm{T}$ & \\
\hline $823 \mathrm{~B}-14 \mathrm{X}-2$ & 45 & 46 & 124.4 & 1.36 & 1.5 & F & VF & & $\mathrm{T}$ & \\
\hline $823 \mathrm{~B}-14 \mathrm{X}-2$ & 58 & 68 & 124.6 & 1.36 & 10.5 & $\mathrm{VF} /$ silt & silt & & $\mathrm{T}$ & \\
\hline $823 \mathrm{~B}-14 \mathrm{X}-2$ & 72 & 75 & 124.7 & 1.36 & 2.6 & VF/silt & silt & & $\mathrm{T}$ & \\
\hline $823 \mathrm{~B}-14 \mathrm{X}-2$ & 92 & 93 & 124.8 & 1.36 & 0.8 & VF/silt & silt & & $\mathrm{T}$ & \\
\hline $823 \mathrm{~B}-14 \mathrm{X}-2$ & 99 & 101 & 124.9 & 1.36 & 0 & VF/silt & silt & & $T$ & \\
\hline $823 \mathrm{~B}-14 \mathrm{X}-2$ & 110 & 113 & 125 & 1.36 & 3.2 & VF/silt & silt & & T & \\
\hline $823 \mathrm{~B}-14 \mathrm{X}-2$ & 122 & 126 & 125.2 & 1.36 & 4 & $\mathrm{VF} /$ silt & silt & & T & \\
\hline $823 \mathrm{~B}-14 \mathrm{X}-2$ & 134 & 138 & 125.3 & 1.36 & 5 & VF/silt & silt & sm… & $\mathrm{T}$ & \\
\hline $823 \mathrm{~B}-14 \mathrm{X}-3$ & 15 & 16 & 125.6 & 1.36 & 1 & VF & VF/silt & sm $\cdots=$ SS & $T$ & \\
\hline $823 \mathrm{~B}-14 \mathrm{X}-3$ & 17 & 18 & 125.6 & 1.36 & 0.5 & VF & VF/silt & mu…SS & $\mathrm{T}$ & \\
\hline $823 B-14 X-3$ & 85 & 87 & 126.3 & 1.37 & 1.5 & VF & VF/silt & мm…SS & $\mathrm{T}$ & \\
\hline $823 \mathrm{~B}-14 \mathrm{X}-3$ & 116 & 117 & 126.6 & 1.37 & 0.8 & VF & VF/silt & mm…SS & $\mathrm{T}$ & \\
\hline $823 \mathrm{~B}-14 \mathrm{X}-3$ & 128 & 130 & 126.7 & 1.37 & 1.8 & $\mathbf{F}$ & VF & мп…SS & $\mathrm{T}$ & \\
\hline $823 \mathrm{~B}-14 \mathrm{X}-4$ & 0 & 1 & 126.9 & 1.37 & 0.8 & VF & VF/silt & мn…SS & $\mathrm{T}$ & \\
\hline $823 \mathrm{~B}-14 \mathrm{X}-4$ & 15 & 16 & 127.1 & 1.37 & 0.9 & VF & VF/silt & mи…SS & $\mathrm{T}$ & \\
\hline $823 \mathrm{~B}-14 \mathrm{X}-4$ & 22 & 23 & 127.1 & 1.37 & 1.3 & VF & VF/silt & mm…SS & $\mathrm{T}$ & \\
\hline
\end{tabular}


Appendix A (continued).

\begin{tabular}{|c|c|c|c|c|c|c|c|c|c|c|c|}
\hline Sample & Top $(\mathrm{cm})$ & $\begin{array}{c}\text { Bottom } \\
(\mathrm{cm})\end{array}$ & Depth (m) & $\begin{array}{c}\text { Age } \\
\text { (ma) }\end{array}$ & Thickness (cm) & Texture Base & Texture Top & Mud cap & $\begin{array}{c}\text { Sedimentary } \\
\text { Structure }\end{array}$ & $\begin{array}{l}\text { Depositional } \\
\text { Mechanism }\end{array}$ & $?$ \\
\hline $823 \mathrm{~B}-14 \mathrm{X}-4$ & 59 & 60 & 127.5 & 1.37 & 1 & VF & VF/silt & mud & mn…5S & $\mathrm{T}$ & \\
\hline $823 \mathrm{~B}-14 \mathrm{X}-4$ & 62 & 66 & 127.6 & 1.37 & 3.5 & VF & VF/silt & mud & mm...SSS & $\mathrm{T}$ & \\
\hline 823B-14X-4 & 91 & 93 & 127.8 & 1.37 & 1.8 & VF & VF/silt & & m슫S & $T$ & \\
\hline $823 B-14 X-4$ & 117 & 118 & 128.1 & 1.37 & 0.4 & VF & VF/silt & & 쓰․ㅡSS & $\mathrm{T}$ & \\
\hline $823 \mathrm{~B}-14 \mathrm{X}-4$ & 120 & 127 & 128.2 & 1.37 & 2.8 & VF & VF/silt & & mn…SS & T & \\
\hline $823 \mathrm{~B}-14 \mathrm{X}-4$ & 128 & 130 & 128.2 & 1.37 & 2.1 & vF & VF/silt & & mn…SS & T & \\
\hline $823 \mathrm{~B}-14 \mathrm{X}-4$ & 141 & 145 & 128.4 & 1.38 & 4.8 & VF & $\mathrm{VF} / \mathrm{mud}$ & & 스토SS & $\mathrm{T}$ & \\
\hline $823 \mathrm{~B}-14 \mathrm{X}-5$ & 30 & 32 & 128.7 & 1.38 & 1.5 & VF & $\mathrm{VF} /$ silt & & mn…SS & $\mathrm{T}$ & \\
\hline $823 \mathrm{~B}-14 \mathrm{X}-5$ & 72 & 77 & 129.2 & 1.38 & 5 & VF & VF/silt & & mn…SS & $\mathrm{T}$ & \\
\hline $823 \mathrm{~B}-14 \mathrm{X}-5$ & 86 & 87 & 129.3 & 1.38 & 0.6 & VF & VF/silt & & мим… & $\mathrm{T}$ & \\
\hline $823 \mathrm{~B}-14 \mathrm{X}-5$ & 118 & 119 & 129.6 & 1.38 & 0.7 & VF & VF/silt & & мnㅡ. & $\mathrm{T}$ & \\
\hline $823 \mathrm{~B}-14 \mathrm{X}-5$ & 136 & 137 & 129.8 & 1.38 & 0.7 & VF & VF/silt & & sn… & $\mathrm{T}$ & \\
\hline $823 \mathrm{~B}-14 \mathrm{X}-6$ & 5 & 7 & 130 & 1.38 & 2.2 & VF & $\mathrm{VF} /$ silt & & мn…SS & $\mathrm{T}$ & \\
\hline $823 B-14 X-6$ & 30 & 36 & 130.3 & 1.38 & 5.4 & VF & $\mathrm{VF} /$ silt & & ㅆ…SS & $\mathrm{T}$ & \\
\hline $823 B-14 X-6$ & 41 & 43 & 130.3 & 1.38 & 1.8 & $\mathrm{~F}$ & $\mathrm{VF} /$ silt & & mn…SS & $\mathrm{T}$ & \\
\hline $823 \mathrm{~B}-14 \mathrm{X}-6$ & 51 & 58 & 130.5 & 1.39 & 7.2 & F & VF/silt & & m…SS & $\mathrm{T}$ & \\
\hline $823 \mathrm{~B}-14 \mathrm{X}-6$ & 67 & 74 & 130.6 & 1.39 & 6.6 & F & VF/silt & & mn…SS & $\mathrm{T}$ & \\
\hline $823 \mathrm{~B}-14 \mathrm{X}-6$ & 91 & 100 & 130.9 & 1.39 & 9 & $\mathrm{~F}$ & $\mathrm{VF} /$ silt & & m…SS & $\mathrm{T}$ & \\
\hline $823 B-14 X-6$ & 107 & 109 & 131 & 1.39 & 1.6 & VF & VF/silt & & mm…SS & $\mathrm{T}$ & \\
\hline $823 B-14 X-6$ & 122 & 126 & 131.2 & 1.39 & 3.5 & $\mathrm{~F}$ & VF & & mu…SS & $\mathrm{T}$ & \\
\hline $823 \mathrm{~B}-14 \mathrm{X}-6$ & 132 & 138 & 131.3 & 1.39 & 6 & $\mathrm{~F}$ & VF & & ми…SS & $\mathrm{T}$ & \\
\hline $823 \mathrm{~B}-14 \mathrm{X}-6$ & 146 & 150 & 131.4 & 1.39 & 3 & VF & VF/silt & & ...SS & $\mathrm{T}$ & \\
\hline 823B-14X-7 & 8 & 9 & 131.5 & 1.39 & 1 & $\mathrm{~F}$ & VF & & mm...SS & $\mathrm{T}$ & \\
\hline $823 \mathrm{~B}-14 \mathrm{X}-7$ & 18 & 21 & 131.6 & 1.39 & 3.4 & $\mathrm{~F}$ & VF & & mm...SS & $T$ & \\
\hline $823 B-14 X-7$ & 27 & 35 & 131.8 & 1.39 & 8.1 & VF & VF/silt & & mm...SS & $\mathrm{T}$ & \\
\hline $823 \mathrm{~B}-14 \mathrm{X}-7$ & 45 & 47 & 131.9 & 1.39 & 2.5 & VF & $\mathrm{VF} /$ silt & & mm...SS & $T$ & \\
\hline $823 \mathrm{~B}-15 \mathrm{X}-1$ & 16 & 150 & 133.6 & 1.4 & 134 & M & 7.5 & & $\operatorname{csB}$ & $\mathrm{DF} / 2$ & \\
\hline $823 \mathrm{~B}-15 \mathrm{X}-2$ & 0 & 150 & 135.1 & 1.41 & 150 & mud & $6.0 \mathrm{~cm}$ & & CSBUתCS & $\mathrm{DF} / 2$ & \\
\hline $823 \mathrm{~B}-15 \mathrm{X}-3$ & 0 & 130 & 136.4 & 1.41 & 130 & mud & $6.5 \mathrm{~cm}$ & & $C S B \cup \bumpeq C S$ & $\mathrm{DF} / 2$ & \\
\hline $823 \mathrm{~B}-15 \mathrm{X}-3$ & 0 & 130 & 136.4 & 1.41 & 414 & mud & $6.5 \mathrm{~cm}$ & & CSB/ $\mathrm{CS}$ & $\mathrm{DF}$ & \\
\hline $823 \mathrm{~B}-15 \mathrm{X}-3$ & 142 & 143 & 136.5 & 1.41 & 0.9 & VF & silt & & мm… & $\mathrm{T}$ & \\
\hline $823 \mathrm{~B}-15 \mathrm{X}-4$ & 110 & 111 & 137.7 & 1.42 & 1 & $\mathrm{VF} / \mathrm{mud}$ & & & мm… & $\mathrm{T}$ in $\mathrm{S}$ & \\
\hline $823 \mathrm{~B}-15 \mathrm{X}-4$ & 130 & 133 & 137.9 & 1.42 & 3.2 & $\mathrm{VF} / \mathrm{mud}$ & & & mm...SS & $\mathrm{T}$ in $\mathrm{S}$ & \\
\hline $823 B-15 X-4$ & 146 & 147 & 138.1 & 1.42 & 1 & VF & silt & & мм… & $\mathrm{T}$ in $\mathrm{S}$ & \\
\hline $823 \mathrm{~B}-15 \mathrm{X}-4$ & 143 & 149 & 138.1 & 1.42 & 0.5 & VF & VF/silt & & $\operatorname{sm} \cdots$ & $\mathrm{T}$ in $\mathrm{S}$ & \\
\hline $823 \mathrm{~B}-15 \mathrm{X}-4$ & 0 & 150 & 138.1 & 1.42 & 150 & $\mathrm{VF} / \mathrm{mud}$ & & & $\Omega \cdots$ & $\mathrm{S}$ & ? \\
\hline $823 \mathrm{~B}-15 \mathrm{X}-5$ & 24 & 116 & 139.3 & 1.43 & 92 & $\mathrm{mud} / \mathrm{F}$ & & & $B V I N$ m $\ldots$ SS & $\mathrm{S} / 2$ & $?$ \\
\hline $823 \mathrm{~B}-15 \mathrm{X}-6$ & 0 & 68 & 140.3 & 1.43 & 194 & mud & & & IN & $\mathrm{s}$ & ? \\
\hline $823 \mathrm{~B}-15 \mathrm{X}-6$ & 88 & 89 & 140.5 & 1.43 & 1 & VF & silt & & mn...SS & $\mathrm{T}$ & \\
\hline $823 \mathrm{~B}-15 \mathrm{X}-6$ & 97 & 102 & 140.6 & 1.43 & 5.4 & $\mathrm{~F}$ & VF & & mи…SS & $\mathrm{T}$ & \\
\hline $823 \mathrm{~B}-15 \mathrm{X}-6$ & 128 & 137 & 141 & 1.43 & 8.8 & $\mathrm{VF} / \mathrm{F}$ & & & muSS & $\mathrm{T}$ & \\
\hline $823 \mathrm{~B}-15 \mathrm{X}-6$ & 137 & 150 & 141.1 & 1.43 & 13 & mud & $3.0 \mathrm{~cm}$ & & mSBU & $\mathrm{DF}$ & \\
\hline $823 \mathrm{~B}-15 \mathrm{X}-7$ & 0 & 1 & 141.1 & 1.43 & 1 & VF/silt & & & & $T$ & \\
\hline $823 \mathrm{~B}-15 \mathrm{X}-0$ & 2 & 3 & 141.3 & 1.44 & 1.5 & $\mathrm{~F}(\mathrm{M})$-VF & & & mi...SS & $\mathrm{T}$ & \\
\hline $823 \mathrm{~B}-16 \mathrm{X}-1$ & 12 & 13 & 141.8 & 1.44 & 0.6 & VF & silt & & $m$ m...SSS & T & \\
\hline $823 \mathrm{~B}-16 \mathrm{X}-1$ & 30 & 31 & 142 & 1.44 & 0.5 & VF & silt & & mm…SS & $\mathrm{T}$ & \\
\hline $823 \mathrm{~B}-16 \mathrm{X}-1$ & 31 & 150 & 143.2 & 1.44 & 119 & $\mathrm{mud} / \mathrm{VF}$ & & & $\Omega \mathbb{N}$ & $s$ & \\
\hline $823 \mathrm{~B}-16 \mathrm{X}-2$ & 4 & 14 & 143.3 & 1.44 & 11 & VF/silt & & & 几S5 & $\mathrm{s}$ & ? \\
\hline $823 \mathrm{~B}-16 \mathrm{X}-2$ & 58 & 62 & 143.8 & 1.45 & 4 & F & VF & & IN m $\ldots S S$ & T & \\
\hline $823 \mathrm{~B}-16 \mathrm{X}-2$ & 69 & 71 & 143.9 & 1.45 & 0.6 & $\mathrm{~F}$ & VF & & IN $\mathrm{mm} \ldots S S$ & $\mathrm{~T}$ & \\
\hline 823B-16X-2 & 83 & 85 & 144.1 & 1.45 & 1.6 & VF & & & мn… & T & \\
\hline $823 \mathrm{~B}-16 \mathrm{X}-2$ & 90 & 91 & 144.1 & 1.45 & 1.1 & M & & & & $T$ & \\
\hline $823 B-16 X-2$ & 91 & 137 & 144.6 & 1.45 & 46.5 & $\mathrm{~F} / \mathrm{M}$ & $\mathrm{F} / \mathrm{VF}$ & & $m m=$ IN & $T$ & \\
\hline $823 \mathrm{~B}-16 \mathrm{X}-4$ & 78 & 88 & 147.1 & 1.46 & 8.5 & VF & VF/silt & & IN m $\cdots$. SS & $\mathrm{T}$ in $\mathrm{S}$ & \\
\hline $823 \mathrm{~B}-16 \mathrm{X}-4$ & 104 & 114 & 147.3 & 1.46 & 8 & $F$ & VF & & IN $m$ m $\ldots$ SS & $\mathrm{T}$ in $\mathrm{S}$ & \\
\hline $823 \mathrm{~B}-16 \mathrm{X}-4$ & 137 & 150 & 147.7 & 1.47 & 13 & $F(m)$ & VF & & ...SS & $\mathrm{T}$ in $\mathrm{S} / 2$ & ? \\
\hline $823 \mathrm{~B}-16 \mathrm{X}-5$ & 1 & 4 & 147.7 & 1.47 & 4 & $\mathrm{~F}$ & VF & & mn… & $\mathrm{T}$ in $\mathrm{S} / 2$ & ? \\
\hline $823 \mathrm{~B}-16 \mathrm{X}-5$ & 1 & 4 & 147.7 & 1.47 & 17 & $\mathrm{~F}$ & VF & & $m m \cdots$ & $\mathrm{T}$ in $\mathrm{S}$ & ? \\
\hline $823 \mathrm{~B}-16 \mathrm{X}-5$ & 5 & 6 & 147.8 & 1.47 & 1 & VF & VF/silt & & мn… & $\mathrm{T}$ in $\mathrm{S}$ & ? \\
\hline $823 \mathrm{~B}-16 \mathrm{X}-5$ & 6 & 8 & 147.8 & 1.47 & 1.8 & VF & VF/silt & & мㅡ… & $\mathrm{T}$ in $\mathrm{S}$ & ? \\
\hline $823 \mathrm{~B}-16 \mathrm{X}-5$ & 9 & 10 & 147.8 & 1.47 & 0.3 & VF & VF/silt & & мпм... & $\mathrm{T}$ in $\mathrm{S}$ & ? \\
\hline $823 \mathrm{~B}-16 \mathrm{X}-5$ & 10 & 12 & 147.8 & 1.47 & 1 & VF & VF/silt & & ммм… & $\mathrm{T}$ in $\mathrm{S}$ & ? \\
\hline $823 \mathrm{~B}-16 \mathrm{X}-5$ & 14 & 15 & 147.9 & 1.47 & 0.6 & $\mathrm{~F}$ & VF & & мㅡㄴ. & $\mathrm{T}$ in $\mathrm{S}$ & ? \\
\hline $823 \mathrm{~B}-16 \mathrm{X}-5$ & 16 & 17 & 147.9 & 1.47 & 1.1 & VF & $\mathrm{VF} /$ silt & & ми… & $T$ in $S$ & ? \\
\hline 823B-16X-5 & 30 & 31 & 148 & 1.47 & 0.6 & VF & VF/silt & & $m$ ㅆ.. & $\mathrm{T}$ in $\mathrm{S}$ & ? \\
\hline
\end{tabular}


Appendix A (continued).

\begin{tabular}{|c|c|c|c|c|c|c|c|c|c|c|}
\hline Sample & Top $(\mathrm{cm})$ & $\begin{array}{c}\text { Bottom } \\
(\mathrm{cm})\end{array}$ & Depth (m) & $\begin{array}{l}\text { Age } \\
\text { (ma) }\end{array}$ & Thickness (cm) & Texture Base & Texture Top Mud cap & $\begin{array}{c}\text { Sedimentary } \\
\text { Structure }\end{array}$ & $\begin{array}{l}\text { Depositional } \\
\text { Mechanism }\end{array}$ & $?$ \\
\hline $823 B-16 X-5$ & 48 & 50 & 148.2 & 1.47 & 2.1 & VF & $\mathrm{VF} / \mathrm{silt}$ & $\mathrm{sm} \ldots$ SS IN & $\mathrm{T}$ in $\mathrm{S}$ & $?$ \\
\hline $823 B-16 X-5$ & 57 & 59 & 148.3 & 1.47 & 2.3 & $\mathrm{~F}$ & VF & $\operatorname{sm} \cdots=S S \mathbb{I N}$ & $\mathrm{T}$ in $\mathrm{S}$ & ? \\
\hline $823 B-16 X-5$ & 60 & 61 & 148.3 & 1.47 & 0.5 & $\mathrm{~F}$ & VF & IN & $\mathrm{T}$ in $\mathrm{S}$ & $?$ \\
\hline $823 \mathrm{~B}-16 \mathrm{X}-5$ & 0 & 61 & 148.3 & 1.47 & 61 & & & $\Omega \mathrm{IN}$ & $\mathrm{S} / 2$ & $?$ \\
\hline $823 B-16 X-5$ & 114 & 115 & 148.9 & 1.47 & 1.1 & VF & VF/silt & nm...SS & $\mathrm{T}$ & $?$ \\
\hline $823 B-16 X-5$ & 120 & 121 & 148.9 & 1.47 & 0.8 & $\mathrm{~F}$ & VF & mm…SS & $\mathbf{T}$ & $?$ \\
\hline $823 \mathrm{~B}-16 \mathrm{X}-6$ & 1 & 2 & 149.2 & 1.47 & 0.2 & VF & $\mathrm{VF} /$ silt & IN $\ldots$ & $\mathrm{T}$ in $\mathrm{S}$ & $?$ \\
\hline $823 B-16 X-6$ & 7 & 10 & 149.3 & 1.47 & 1.4 & VF & VF/silt & …几SS & $\mathrm{T}$ in $\mathrm{S}$ & ? \\
\hline $823 B-16 X-6$ & 12 & 15 & 149.4 & 1.47 & 1.7 & $\mathrm{~F}$ & VF & IN $\ldots$ & $\mathrm{T}$ in $\mathrm{S}$ & $?$ \\
\hline $823 \mathrm{~B}-16 \mathrm{X}-6$ & 15 & 18 & 149.4 & 1.47 & 1.9 & F & VF & IN $\ldots$ & $\mathrm{T}$ in $\mathrm{S}$ & $?$ \\
\hline $823 B-16 X-6$ & 18 & 21 & 149.4 & 1.47 & 1.3 & VF & VF/silt & IN m $\ldots$... SS & $\mathrm{T}$ in $\mathrm{S}$ & $?$ \\
\hline $823 B-16 X-6$ & 35 & 42 & 149.6 & 1.47 & 2.8 & F/VF & & IN mm \#SS & $\mathrm{T}$ in $\mathrm{S}$ & ? \\
\hline $823 B-16 X-6$ & 56 & 58 & 149.8 & 1.47 & 1.6 & $\mathrm{~F} / \mathrm{VF}$ & & $\mathbb{I N}$ mm $\ldots$ SS & $\mathrm{T}$ in $\mathrm{S}$ & ? \\
\hline $823 B-16 X-6$ & 67 & 72 & 149.9 & 1.48 & 0 & $\mathrm{~F} / \mathrm{VF}$ & & mu…SS & $\mathrm{T}$ in $\mathrm{S}$ & $?$ \\
\hline $823 B-16 X-6$ & 72 & 73 & 149.9 & 1.48 & 0.5 & VF & VF/silt & mm...SS & $\mathrm{T}$ in $\mathrm{S}$ & ? \\
\hline $823 B-16 X-6$ & 93 & 94 & 150.1 & 1.48 & 0.4 & VF & VF/silt & IN $\ldots$ SS & $\mathrm{T}$ in $\mathrm{S}$ & \\
\hline $823 B-16 X-6$ & 0 & 106 & 150.3 & 1.48 & 106 & mud & VF & $\mathbb{I N} \Omega$ & $\mathrm{S}$ & ? \\
\hline $823 B-16 X-6$ & 110 & 111 & 150.3 & 1.48 & 0.3 & VF & VF/silt & IN ... SS & $\mathrm{T}$ in $\mathrm{S}$ & ? \\
\hline $823 B-16 X-6$ & 115 & 116 & 150.4 & 1.48 & 0.2 & VF & $\mathrm{VF} /$ silt & IN $\ldots$ SS & $\mathrm{T}$ in $\mathrm{S}$ & ? \\
\hline $823 B-17 X-1$ & 0 & 150 & 152.9 & 1.58 & 150 & mud & $4 \mathrm{~cm}$ & $\mathrm{CS}$ IN MS & $\mathrm{S} / 2$ & ? \\
\hline $823 \mathrm{~B}-17 \mathrm{X}-2$ & 0 & 43 & 153.3 & 1.6 & 43 & mud & $2.2 \mathrm{~cm}$ & $C S B U I N$ & DF to $S$ & \\
\hline $823 \mathrm{~B}-17 \mathrm{X}-2$ & 47 & 50 & 153.4 & 1.6 & 1.3 & VF & $\mathrm{VF} /$ silt & IN & $\mathrm{T}$ in $\mathrm{S}$ & $?$ \\
\hline $823 \mathrm{~B}-17 \mathrm{X}-2$ & 53 & 55 & 153.5 & 1.6 & 2.2 & VF & VF/silt & IN & $\mathrm{T}$ in $\mathrm{S}$ & ? \\
\hline $823 B-17 X-2$ & 66 & 68 & 153.6 & 1.6 & 0.3 & VF & $\mathrm{VF} /$ silt & IN & $\mathrm{T}$ in $\mathrm{S}$ & ? \\
\hline $823 \mathrm{~B}-17 \mathrm{X}-2$ & 75 & 77 & 153.7 & 1.6 & 2 & VF & $\mathrm{VF} /$ silt & IN & $\mathrm{T}$ in $\mathrm{S}$ & ? \\
\hline $823 \mathrm{~B}-17 \mathrm{X}-2$ & 133 & 134 & 154.2 & 1.6 & 1.1 & VF & $\mathrm{VF} /$ silt & IN & $\mathrm{T}$ in $\mathrm{S}$ & $?$ \\
\hline $823 B-17 X-2$ & 138 & 141 & 154.3 & 1.6 & 1 & VF & $\mathrm{VF} /$ silt & IN & $\mathrm{T}$ in $\mathrm{S}$ & ? \\
\hline $823 B-17 X-2$ & 0 & 141 & 154.3 & 1.6 & 141 & mud & $4 \mathrm{~cm}$ & $\mathrm{CS}$ IN MS & $\mathrm{S} / 2$ & \\
\hline $823 \mathrm{~B}-17 \mathrm{X}-2$ & 0 & 141 & 154.3 & 1.6 & 291 & mud & $4 \mathrm{~cm}$ & $\mathrm{CS} I \mathrm{~N} \mathrm{MS}$ & $\mathrm{S}$ & \\
\hline $823 B-17 X-2$ & 146 & 147 & 154.4 & 1.6 & 0.2 & VF & VF/silt & mu…SS & $\mathrm{T}$ & \\
\hline $823 \mathrm{~B}-17 \mathrm{X}-3$ & 0 & 1 & 154.4 & 1.6 & 0.5 & VF & VF/silt & mn…SS & $\mathrm{T}$ & \\
\hline $823 B-17 X-3$ & 18 & 19 & 154.6 & 1.61 & 0.9 & VF & $\mathrm{VF} /$ silt & m....SS & $\mathrm{T}$ & \\
\hline $823 B-17 X-3$ & 45 & 46 & 154.9 & 1.61 & 0.6 & VF & VF/silt & $m m \ldots 5 S$ & $\mathrm{~T}$ & \\
\hline $823 B-17 X-3$ & 53 & 54 & 154.9 & 1.61 & 0.5 & VF & VF/silt & $m m \ldots S S$ & $\mathrm{~T}$ & \\
\hline $823 \mathrm{~B}-17 \mathrm{X}-3$ & 63 & 66 & 155.1 & 1.61 & 0.3 & VF & VF/silt & & $\mathrm{T}$ & \\
\hline $823 \mathrm{~B}-17 \mathrm{X}-3$ & 99 & 100 & 155.4 & 1.61 & 0.5 & $\mathrm{~F}$ & VF & mn…SS & $\mathrm{T}$ & \\
\hline $823 \mathrm{~B}-17 \mathrm{X}-3$ & 125 & 133 & 155.7 & 1.61 & 8 & $\mathrm{~F}$ & VF & ...SS & $\mathrm{T}$ & \\
\hline $823 \mathrm{~B}-17 \mathrm{X}-3$ & 145 & 150 & 155.9 & 1.61 & 4.3 & $\mathrm{~F}$ & VF & ...SS & $\mathrm{T}$ & \\
\hline $823 \mathrm{~B}-17 \mathrm{X}-4$ & 0 & 6 & 156 & 1.61 & 3.5 & $\mathrm{~F}$ & VF/silt & SS min...SS & $\mathrm{T}$ & \\
\hline $823 B-17 X-4$ & 8 & 9 & 156 & 1.61 & 0.8 & $\mathrm{~F}$ & VF/silt & SS mu…SS & $\mathrm{T}$ & \\
\hline $823 \mathrm{~B}-17 \mathrm{X}-4$ & 30 & 32 & 156.2 & 1.61 & 1.6 & VF & VF/silt & IN SS m $\ldots$... SS & $\mathrm{T}$ & \\
\hline $823 B-17 X-4$ & 48 & 49 & 156.4 & 1.61 & 1 & VF & $\mathrm{VF} / \mathrm{silt}$ & SS mm…SS & $\mathrm{T}$ & \\
\hline $823 B-17 X-4$ & 82 & 90 & 156.8 & 1.61 & 7.8 & $\mathrm{~F}$ & VF/silt & & $\mathrm{T}$ & \\
\hline $823 B-17 X-4$ & 96 & 104 & 156.9 & 1.61 & 7.6 & F & VF/silt & SS mm …SS & $\mathrm{T}$ & \\
\hline $823 B-17 X-4$ & 109 & 115 & 157.1 & 1.62 & 6 & VF/mud & & 55 & $\mathrm{~T}$ & ? \\
\hline $823 B-17 X-4$ & 119 & 124 & 157.1 & 1.62 & 5 & F & VF & INSS $\mathrm{mm} \cdots=$ & $\mathrm{T}$ & ? \\
\hline $823 B-17 X-4$ & 127 & 130 & 157.2 & 1.62 & 2.2 & VF & VF/silt & mm…SS & $\mathrm{T}$ in $\mathrm{S}$ & ? \\
\hline $823 \mathrm{~B}-17 \mathrm{X}-4$ & 131 & 132 & 157.2 & 1.62 & 0.8 & $\mathrm{~F}$ & VF/silt & mm...SS & $\mathrm{T}$ & \\
\hline $823 \mathrm{~B}-17 \mathrm{X}-5$ & 18 & 21 & 157.6 & 1.62 & 2.5 & VF & VF/silt & $m n=5 S$ & $\mathrm{~T}$ & \\
\hline $823 B-17 X-5$ & 29 & 30 & 157.7 & 1.62 & 0.7 & VF & VF/silt & $\operatorname{mm} \ldots$...SS & $\mathrm{T}$ & \\
\hline $823 B-17 X-5$ & 46 & 47 & 157.9 & 1.62 & 1.1 & $\mathrm{~F}$ & VF & $m m \ldots 5 S$ & $\mathrm{~T}$ & \\
\hline $823 B-17 X-5$ & 76 & 77 & 158.2 & 1.62 & 0.2 & VF & silt & mn…SS & $\mathbf{T}$ & \\
\hline $823 B-17 X-5$ & 123 & 126 & 158.7 & 1.62 & 2.6 & F & VF & mu…SS & $\mathrm{T}$ & \\
\hline $823 B-18 X-1$ & 0 & 150 & 162.6 & 1.64 & 150 & mud & $5.5 \mathrm{~cm}$ & $\sim B V$ & $\mathrm{~S}$ or $\mathrm{DF} / 2$ & \\
\hline $823 \mathrm{~B}-18 \mathrm{X}-2$ & 0 & 150 & 164.1 & 1.64 & 150 & mud & $21 \mathrm{~cm}$ & $\mathrm{~ms} \Omega \mathrm{CS}$ & $\mathrm{DF} / 2$ & \\
\hline $823 \mathrm{~B}-18 \mathrm{X}-3$ & 0 & 115 & 165.3 & 1.65 & 115 & mud & $20 \mathrm{~cm}$ & msBV & $\mathrm{DF} / 2$ & \\
\hline $823 B-18 X-4$ & 0 & 150 & 167.1 & 1.65 & 150 & mud & $6.5 \mathrm{~cm}$ & $\mathrm{~ms} \Omega \mathrm{Cs}$ & $\mathrm{DF} / 2$ & \\
\hline $823 \mathrm{~B}-18 \mathrm{X}-5$ & 0 & 21 & 167.3 & 1.65 & 21 & & & & $\mathrm{DF} / 2$ & ? \\
\hline $823 B-18 X-5$ & 0 & 21 & 167.3 & 1.65 & 621 & & & & DF & \\
\hline $823 \mathrm{~B}-18 \mathrm{X}-5$ & 33 & 34 & 167.4 & 1.66 & 0.4 & VF/silt & & & $\mathrm{T}$ & \\
\hline $823 \mathrm{~B}-18 \mathrm{X}-5$ & 103 & 106 & 168.2 & 1.66 & 0.8 & VF/silt & & m … SS IN & $\mathrm{T}$ in $\mathrm{S}$ & \\
\hline $823 \mathrm{~B}-18 \mathrm{X}-5$ & 141 & 142 & 168.5 & 1.66 & 0.5 & VF/silt & & mu…SS & $\mathrm{T}$ in $\mathrm{S}$ & ? \\
\hline $823 B-18 X-5$ & 103 & 150 & 168.6 & 1.66 & 47 & & & IN & $\mathrm{S} / 2$ & $?$ \\
\hline $823 \mathrm{~B}-18 \mathrm{X}-6$ & 1 & 2 & 168.6 & 1.66 & 0.5 & VF/silt & & IN m $\ldots$... SS & $\mathrm{T}$ in $\mathrm{S}$ & $?$ \\
\hline $823 \mathrm{~B}-18 \mathrm{X}-6$ & 10 & 13 & 168.7 & 1.66 & 0.5 & VF/silt & & IN m S SS & $\mathrm{T}$ in $\mathrm{S}$ & ? \\
\hline
\end{tabular}


Appendix A (continued).

\begin{tabular}{|c|c|c|c|c|c|c|c|c|c|c|}
\hline Sample & Top $(\mathrm{cm})$ & $\begin{array}{l}\text { Bottom } \\
\text { (cm) }\end{array}$ & Depth (m) & $\begin{array}{l}\text { Age } \\
\text { (ma) }\end{array}$ & Thickness (cm) & Texture Base & Texture Top Mud cap & $\begin{array}{l}\text { Sedimentary } \\
\text { Structure }\end{array}$ & $\begin{array}{l}\text { Depositional } \\
\text { Mechanism }\end{array}$ & $?$ \\
\hline $823 \mathrm{~B}-18 \mathrm{X}-0$ & 40 & 43 & 170.5 & 1.67 & 0.9 & $\mathrm{~F}(\mathrm{C})$ & VF & IN $m \cdots 5 S$ & $\mathrm{~T}$ in $\mathrm{S}$ & $?$ \\
\hline $823 \mathrm{~B}-18 \mathrm{X}-0$ & 45 & 48 & 170.6 & 1.67 & 1.6 & VF & VF/silt & $I N \mathrm{~mm} \ldots S S$ & $T$ in $S$ & $?$ \\
\hline 823B-18X-0 & 0 & 48 & 170.6 & 1.67 & 48 & & & IN & $\mathrm{s} / 2$ & \\
\hline 823B-19X-1 & 7 & 10 & 170.9 & 1.67 & 0.7 & VF & VF/silt & IN & $T$ in $S$ & ? \\
\hline 823B-19X-1 & 0 & 10 & 170.9 & 1.67 & 10 & & & IN & $\mathrm{s} / 2$ & ? \\
\hline 823B-19X-1 & 0 & 10 & 170.9 & 1.67 & 223 & & & IN & $\mathrm{S}$ & ? \\
\hline 823B-19X-1 & 40 & 45 & 171.3 & 1.67 & 4 & VF & VF/silt & mn…SS & $\mathrm{T}$ & \\
\hline 823B-19X-1 & 47 & 48 & 171.3 & 1.67 & 0.5 & VF & VF/silt & mn…SS & $\mathrm{T}$ & \\
\hline 823B-19X-1 & 86 & 92 & 171.7 & 1.67 & 5.9 & $\mathrm{~F}$ & VF/silt & $m m \cdots=S S$ & $\mathrm{~T}$ & \\
\hline 823B-19X-1 & 95 & 101 & 171.8 & 1.67 & 4.6 & $\mathrm{~F}$ & & mm...SSS & $T$ & \\
\hline 823B-19X-1 & 141 & 145 & 172.3 & 1.67 & 3.5 & VF & VF/silt & m...SSS & $\mathrm{T}$ & \\
\hline 823B-19X-2 & 3 & 4 & 172.3 & 1.67 & 0.4 & VF & VF/silt & mu…SSS & $\mathrm{T}$ & \\
\hline 823B-19X-2 & 89 & 92 & 173.2 & 1.68 & 2.2 & VF & VF/silt & m...SSS & $\mathrm{T}$ & \\
\hline $823 \mathrm{~B}-19 \mathrm{X}-2$ & 101 & 105 & 173.4 & 1.68 & 3 & $\mathrm{~F}$ & $\mathrm{VF} / \mathrm{mud}$ & mu…SSS & $T$ & \\
\hline $823 \mathrm{~B}-19 \mathrm{X}-2$ & 121 & 123 & 173.5 & 1.68 & 0.9 & VF & $\mathrm{VF} /$ silt & mu...SSS & $\mathrm{T}$ & \\
\hline $823 \mathrm{~B}-19 \mathrm{X}-2$ & 134 & 136 & 173.7 & 1.68 & 1.5 & $\mathrm{~F}$ & $\mathrm{VF}$ & $m m \ldots S S S$ & $\mathrm{~T}$ & \\
\hline $823 \mathrm{~B}-19 \mathrm{X}-3$ & 35 & 36 & 174.2 & 1.68 & 0.3 & VF & silt & $m m \cdots=S S$ & $\mathrm{~T}$ & \\
\hline 823B-19X-3 & 75 & 77 & 174.6 & 1.68 & 1.7 & $\mathrm{~F}$ & VF & mm…SS & $\mathrm{T}$ & \\
\hline $823 \mathrm{~B}-19 \mathrm{X}-3$ & 90 & 95 & 174.8 & 1.68 & 5 & F & VF & ми…SS & $\mathrm{T}$ & \\
\hline $823 \mathrm{~B}-19 \mathrm{X}-4$ & 0 & 150 & 176.8 & 1.69 & 150 & & & IN m $\ldots$ SS & $\mathrm{S} / 2$ & \\
\hline $823 \mathrm{~B}-19 \mathrm{X}-5$ & 2 & 3 & 176.8 & 1.69 & 0.5 & VF & silt & nnㅡ…SS & $T$ in $S$ & ? \\
\hline $823 \mathrm{~B}-19 \mathrm{X}-5$ & 34 & 36 & 177.2 & 1.69 & 2.8 & VF & silt & mm…SS & $T$ in $S$ & $?$ \\
\hline 823B-19X-5 & 37 & 43 & 177.2 & 1.69 & 2.2 & VF & silt & IN $m$ m $\ldots$ SS & $\mathrm{T}$ in $\mathrm{S}$ & \\
\hline 823B-19X-5 & 55 & 59 & 177.4 & 1.69 & 1 & VF & silt & IN $\mathrm{mm} \ldots$ SS & $\mathrm{T}$ in $\mathrm{S}$ & \\
\hline 823B-19X-5 & 36 & 150 & 178.3 & 1.7 & 114 & & & IN m $\ldots$ SS & $\mathrm{S} / 2$ & \\
\hline 823B-19X-5 & 0 & 150 & 178.3 & 1.7 & 150 & & & IN m $\ldots$ SS & $\mathrm{S} / 2$ & \\
\hline 823B-19X-6 & 36 & 42 & 178.7 & 1.7 & 5.6 & VF & silt & $\Omega \mathrm{mm}$ & $\mathrm{T}$ in $\mathrm{S}$ & ? \\
\hline 823B-19X-6 & 0 & 42 & 178.7 & 1.7 & 42 & & & IN w $\ldots$ SS & $\mathrm{S} / 2$ & \\
\hline 823B-19X-6 & 0 & 42 & 178.7 & 1.7 & 376 & & & IN w $\ldots$ SS & $\mathrm{s}$ & \\
\hline 823B-19X-6 & 82 & 88 & 179.2 & 1.7 & 5 & VF & VF/silt & mm…SS & $T$ & \\
\hline 823B-19X-6 & 95 & 101 & 179.3 & 1.7 & 6.2 & VF & VF/silt & ми…SS & $\mathrm{T}$ & \\
\hline $823 \mathrm{~B}-19 \mathrm{X}-0$ & 0 & 3 & 180 & 1.7 & 3.5 & $\mathrm{~F}(\mathrm{C})$ & VF & ми… & $\mathrm{T}$ & ? \\
\hline 823B-19X-0 & 9 & 15 & 180.2 & 1.71 & 5.8 & VF & VF/silt & \#SS & $\mathrm{T}$ & \\
\hline $823 \mathrm{~B}-20 \mathrm{X}-1$ & 8 & 38 & 180.9 & 1.71 & 30 & mud & & $\Omega$ & $\mathrm{s}$ & \\
\hline 823B-20X-1 & 119 & 120 & 181.7 & 1.71 & 0.5 & $\mathrm{~F}(\mathrm{M})$ & $\mathrm{VF}$ & \#SS & $\mathrm{T}$ & \\
\hline 823B-20X-1 & 147 & 150 & 182 & 1.71 & 2.5 & $\mathrm{~F}$ & VF & \#SS & $\mathrm{T}$ & \\
\hline $823 \mathrm{~B}-20 \mathrm{X}-2$ & 3 & 5 & 182.1 & 1.71 & 1.3 & F & vF & мm…SS & $\mathrm{T}$ & \\
\hline $823 \mathrm{~B}-20 \mathrm{X}-2$ & 17 & 20 & 182.2 & 1.71 & 3 & $\mathrm{~F}$ & VF & мm…SS & $\mathrm{T}$ & \\
\hline $823 \mathrm{~B}-20 \mathrm{X}-2$ & 23 & 24 & 182.2 & 1.71 & 1.3 & VF & silt & 쓰…SS & $\mathrm{T}$ & \\
\hline $823 \mathrm{~B}-20 \mathrm{X}-2$ & 25 & 26 & 182.3 & 1.71 & 0.5 & VF & VF/silt & mm...SS & $\mathrm{T}$ & \\
\hline $823 \mathrm{~B}-20 \mathrm{X}-2$ & 30 & 32 & 182.3 & 1.71 & 2.5 & $\mathrm{VF} / \mathrm{F}$ & VF/silt & mm...SS & $\mathrm{T}$ & \\
\hline $823 \mathrm{~B}-20 \mathrm{X}-2$ & 32 & 37 & 182.4 & 1.71 & 0.7 & VF & $\mathrm{VF} /$ silt & ми… & $\mathrm{T}$ & \\
\hline $823 \mathrm{~B}-20 \mathrm{X}-2$ & 104 & 150 & 183.5 & 1.72 & 46 & mud & $5.0 \mathrm{~cm}$ & cSmsBU $\sim \mathrm{ms}$ & $\mathrm{DF} / 2$ & \\
\hline $823 \mathrm{~B}-20 \mathrm{X}-3$ & 0 & 150 & 185 & 1.72 & 150 & mud & $70.0 \mathrm{~cm}$ & MSBU $几$ CS & $\mathrm{DF} / 2$ & \\
\hline $823 \mathrm{~B}-20 \mathrm{X}-4$ & 0 & 150 & 186.5 & 1.73 & 150 & mud & $17 \mathrm{~cm}$ & MSBU $几 C S$ & $\mathrm{DF} / 2$ & \\
\hline $823 \mathrm{~B}-20 \mathrm{X}-0$ & 0 & 39 & 186.9 & 1.73 & 39 & mud & $15 \mathrm{~cm}$ & MSBU $几 C S$ & $\mathrm{DF} / 2$ & \\
\hline $823 \mathrm{~B}-20 \mathrm{X}-0$ & 0 & 39 & 186.9 & 1.73 & 385 & & & $\mathrm{mSBU} \Omega \mathrm{CS}$ & DF & \\
\hline $823 \mathrm{~B}-21 \mathrm{X}-1$ & 46 & 48 & 190.7 & 1.75 & 1.7 & VF/silt & & Ss & $\mathrm{T}$ & ? \\
\hline $823 \mathrm{~B}-21 \mathrm{X}-1$ & 74 & 83 & 191 & 1.75 & 9.4 & VF & & & $\mathrm{T}$ & $?$ \\
\hline $823 \mathrm{~B}-21 \mathrm{X}-1$ & 100 & 101 & 191.2 & 1.75 & 0.6 & VF & VF/silt & мm...SS & $\mathrm{T}$ & \\
\hline $823 \mathrm{~B}-21 \mathrm{X}-1$ & 105 & 110 & 191.3 & 1.75 & 4.5 & VF & VF/silt & mm...SS & $\mathrm{T}$ & \\
\hline $823 \mathrm{~B}-21 \mathrm{X}-1$ & 130 & 136 & 191.6 & 1.75 & 5 & VF & silt & $m$ m...SS & $\mathrm{T}$ & \\
\hline $823 \mathrm{~B}-21 \mathrm{X}-2$ & 88 & 91 & 192.6 & 1.75 & 2.8 & VF/silt & mud & SS & & \\
\hline $823 \mathrm{~B}-21 \mathrm{X}-3$ & 89 & 91 & 194.1 & 1.76 & 2.5 & VF/silt & mud & SS & & \\
\hline $823 \mathrm{~B}-21 \mathrm{X}-3$ & 100 & 101 & 194.2 & 1.76 & 1.4 & VF & silt & mи…SS & $\mathrm{T}$ & \\
\hline $823 \mathrm{~B}-21 \mathrm{X}-3$ & 107 & 108 & 194.3 & 1.76 & 1 & VF & & & $\mathrm{T}$ & \\
\hline $823 \mathrm{~B}-21 \mathrm{X}-5$ & 68 & 69 & 196.9 & 1.77 & 0 & VF/silt & & SS & $\mathrm{T}$ & \\
\hline $823 \mathrm{~B}-21 \mathrm{X}-5$ & 85 & 90 & 197.1 & 1.77 & 4.8 & VF & silt & mm...SS & $\mathrm{T}$ & \\
\hline $823 \mathrm{~B}-21 \mathrm{X}-5$ & 115 & 116 & 197.4 & 1.77 & 1.1 & VF & silt & & $\mathrm{T}$ & \\
\hline 823B-21X-5 & 123 & 126 & 197.5 & 1.77 & 3 & VF & silt & ...SS & $\mathrm{T}$ & \\
\hline $823 \mathrm{~B}-21 \mathrm{X}-6$ & 17 & 19 & 197.9 & 1.77 & 1.5 & VF & silt & мп…SS & $\mathrm{T}$ & \\
\hline $823 \mathrm{~B}-21 \mathrm{X}-6$ & 51 & 54 & 198.2 & 1.78 & 2.3 & VF & silt & & & ? \\
\hline $823 \mathrm{~B}-22 \mathrm{X}-1$ & 8 & 9 & 199.9 & 1.78 & 1.3 & VF & silt & mu…SS & $\mathrm{T}$ & \\
\hline $823 \mathrm{~B}-21 \mathrm{X}-0$ & 45 & 48 & 199.9 & 1.78 & 2.5 & VF & silt & mm...SS & $\mathrm{T}$ & \\
\hline $823 \mathrm{~B}-22 \mathrm{X}-1$ & 33 & 34 & 200.1 & 1.78 & 0.4 & VF & silt & mm…SS & $\mathrm{T}$ & \\
\hline
\end{tabular}


Appendix A (continued).

\begin{tabular}{|c|c|c|c|c|c|c|c|c|c|c|}
\hline Sample & Top $(\mathrm{cm})$ & $\begin{array}{c}\text { Bottom } \\
(\mathrm{cm})\end{array}$ & Depth (m) & $\begin{array}{c}\text { Age } \\
\text { (ma) }\end{array}$ & Thickness (cm) & Texture Base & Texture Top Mud cap & $\begin{array}{l}\text { Sedimentary } \\
\text { Structure }\end{array}$ & $\begin{array}{l}\text { Depositional } \\
\text { Mechanism }\end{array}$ & $?$ \\
\hline $823 \mathrm{~B}-22 \mathrm{X}-1$ & 42 & 45 & 200.3 & 1.78 & 2.3 & VF & silt & mm...SS & $\mathrm{T}$ & \\
\hline $823 \mathrm{~B}-22 \mathrm{X}-1$ & 47 & 48 & 200.3 & 1.78 & 0.5 & VF & silt & mi...SS & $\mathrm{T}$ & \\
\hline $823 \mathrm{~B}-22 \mathrm{X}-1$ & 61 & 62 & 200.4 & 1.78 & 0.4 & VF & silt & mm…SS & $\mathrm{T}$ & \\
\hline $823 \mathrm{~B}-22 \mathrm{X}-1$ & 63 & 65 & 200.5 & 1.78 & 2.2 & VF & silt & min. ㄷS & $\mathrm{T}$ & \\
\hline $823 \mathrm{~B}-22 \mathrm{X}-1$ & 81 & 82 & 200.6 & 1.78 & 0.9 & VF & silt & mm...SS & $\mathrm{T}$ & \\
\hline $823 \mathrm{~B}-22 \mathrm{X}-1$ & 93 & 94 & 200.7 & 1.79 & 0.8 & VF & silt & mm...SS & $\mathrm{T}$ & \\
\hline $823 \mathrm{~B}-22 \mathrm{X}-1$ & 99 & 102 & 200.8 & 1.79 & 3 & VF & silt & mo...SS & $\mathrm{T}$ & \\
\hline $823 \mathrm{~B}-22 \mathrm{X}-1$ & 103 & 104 & 200.8 & 1.79 & 1.1 & VF & & mm...SS & $\mathrm{T}$ & \\
\hline $823 \mathrm{~B}-22 \mathrm{X}-1$ & 108 & 112 & 200.9 & 1.79 & 1 & VF & & & $\mathrm{T}$ & \\
\hline $823 \mathrm{~B}-22 \mathrm{X}-1$ & 115 & 116 & 201 & 1.79 & 1 & VF & & & $\mathrm{T}$ & \\
\hline $823 \mathrm{~B}-22 \mathrm{X}-1$ & 117 & 118 & 201 & 1.79 & 0.9 & VF & silt & & $T$ & \\
\hline $823 \mathrm{~B}-22 \mathrm{X}-1$ & 120 & 121 & 201 & 1.79 & 1.5 & VF & silt & mm...SS & $\mathrm{T}$ & \\
\hline $823 \mathrm{~B}-22 \mathrm{X}-1$ & 122 & 124 & 201 & 1.79 & 1.6 & VF & silt & mm...SS & $\mathrm{T}$ & \\
\hline $823 B-22 X-2$ & 12 & 16 & 201.5 & 1.79 & 4.8 & VF & silt & mm...SS & $\mathrm{T}$ & \\
\hline $823 B-22 X-2$ & 17 & 18 & 201.5 & 1.79 & 1.2 & M & VF & mm...SS & $\mathrm{T}$ & \\
\hline $823 \mathrm{~B}-22 \mathrm{X}-2$ & 33 & 39 & 201.7 & 1.79 & 4.9 & $\mathrm{~F}$ & VF & mm...SS & $\mathrm{T}$ & \\
\hline $823 \mathrm{~B}-22 \mathrm{X}-2$ & 51 & 53 & 201.8 & 1.79 & 1.8 & silt/VF & & & $\mathrm{T}$ & \\
\hline $823 \mathrm{~B}-22 \mathrm{X}-2$ & 66 & 67 & 202 & 1.79 & 0.7 & VF & VF/silt & mn...SS & $\mathrm{T}$ & \\
\hline $823 \mathrm{~B}-22 \mathrm{X}-2$ & 76 & 84 & 202.1 & 1.79 & 8.8 & VF & VF/silt & mm...SS & $\mathrm{T}$ & \\
\hline $823 \mathrm{~B}-22 \mathrm{X}-2$ & 90 & 99 & 202.3 & 1.79 & 5 & VF & VF/silt & ми…SS & $\mathrm{T}$ & \\
\hline $823 \mathrm{~B}-22 \mathrm{X}-2$ & 125 & 138 & 202.7 & 1.79 & 12.3 & VF/silt & silt & mn...SS & $\mathrm{T}$ & \\
\hline $823 \mathrm{~B}-22 \mathrm{X}-2$ & 139 & 149 & 202.8 & 1.79 & 4.1 & VF & silt & $\cdots=S S$ & $\mathrm{~T}$ & \\
\hline $823 \mathrm{~B}-22 \mathrm{X}-3$ & 0 & 2 & 202.8 & 1.79 & 2.4 & $\mathrm{VF} / \mathrm{F}$ & VF & $\ddot{*}=$ & $\mathrm{T}$ & \\
\hline $823 \mathrm{~B}-22 \mathrm{X}-3$ & 14 & 21 & 203 & 1.79 & 7.5 & VF & silt & mm...5S & $\mathrm{T}$ & \\
\hline $823 \mathrm{~B}-22 \mathrm{X}-3$ & 35 & 40 & 203.2 & 1.79 & 2 & VF & silt & mm...SS & $T$ & \\
\hline $823 \mathrm{~B}-22 \mathrm{X}-3$ & 86 & 87 & 203.7 & 1.8 & 0.9 & VF & silt & mи…SS & $\mathrm{T}$ & \\
\hline $823 \mathrm{~B}-22 \mathrm{X}-4$ & 19 & 24 & 204.5 & 1.8 & 5 & $\mathrm{~F}$ & silt & mm...SS & $\mathrm{T}$ & \\
\hline $823 B-22 X-4$ & 26 & 37 & 204.7 & 1.8 & 4 & $\mathrm{~F}(\mathrm{~m})$ & silt & mm...SS & $T$ & \\
\hline $823 \mathrm{~B}-22 \mathrm{X}-4$ & 71 & 80 & 205.1 & 1.82 & 7.2 & VF & silt & $m m \cdots=S S$ & $T$ & \\
\hline $823 \mathrm{~B}-22 \mathrm{X}-4$ & 95 & 102 & 205.3 & 1.82 & 7 & $\mathrm{~F}$ & silt & mm...SS & $\mathrm{T}$ & \\
\hline $823 \mathrm{~B}-22 \mathrm{X}-4$ & 123 & 126 & 205.6 & 1.83 & 2 & $\mathrm{~F}$ & VF & mm...SS & $T$ & \\
\hline $823 B-22 X-5$ & 0 & 27 & 206.1 & 1.84 & 25.5 & $\mathrm{VF} / \mathrm{F}$ & VF/silt & $\underline{\cdots}=$ & $T$ & \\
\hline $823 B-22 X-5$ & 82 & 89 & 206.7 & 1.86 & 2.7 & $\mathrm{~F}$ & VF/silt & $m=55$ & $\mathrm{~T}$ & \\
\hline $823 B-22 X-5$ & 120 & 127 & 207.1 & 1.87 & 7.2 & $\mathrm{M} / \mathrm{F}$ & VF/silt & мим $\cdots=S S$ & $T$ & \\
\hline $823 B-22 X-6$ & 2 & 6 & 207.4 & 1.88 & 3.8 & $\mathrm{~F}$ & & mnsS & $T$ & \\
\hline $823 \mathrm{~B}-22 \mathrm{X}-6$ & 34 & 52 & 207.8 & 1.89 & 17.8 & F & VF/silt & mm...SS & $T$ & \\
\hline $823 \mathrm{~B}-22 \mathrm{X}-6$ & 55 & 60 & 207.9 & 1.89 & 4.8 & $\mathrm{~F}$ & VF/silt & mm...SS & $T$ & \\
\hline $823 \mathrm{~B}-22 \mathrm{X}-6$ & 60 & 150 & 208.8 & 1.92 & 90 & & & CSBV & $\mathrm{DF} / 2$ & \\
\hline $823 \mathrm{~B}-22 \mathrm{X}-7$ & 0 & 31 & 209.1 & 1.93 & 31 & mud & $4 \mathrm{~cm}$ & $\mathrm{~ms}$ & $\mathrm{DF} / 2$ & \\
\hline $823 \mathrm{~B}-22 \mathrm{X}-0$ & 0 & 50 & 209.1 & 1.93 & 50 & mud & $2.8 \mathrm{~cm}$ & CS & $\mathrm{DF} / 2$ & \\
\hline $823 \mathrm{~B}-22 \mathrm{X}-0$ & 0 & 50 & 209.1 & 1.93 & 171 & & & & DF & \\
\hline $823 \mathrm{~B}-23 \mathrm{X}-1$ & 18 & 19 & 209.3 & 1.93 & 0.3 & VF & silt & & $\mathrm{T}$ & \\
\hline $823 \mathrm{~B}-23 \mathrm{X}-1$ & 22 & 23 & 209.3 & 1.93 & 0.5 & VF & silt & $m m=S S \equiv$ & $\mathrm{T}$ & \\
\hline $823 \mathrm{~B}-23 \mathrm{X}-1$ & 46 & 47 & 209.6 & 1.94 & 1 & $\mathrm{~F}$ & mud & $m m \cdots=S S$ & $\mathrm{~T}$ & \\
\hline $823 \mathrm{~B}-23 \mathrm{X}-1$ & 54 & 55 & 209.7 & 1.94 & 0.8 & VF & mud & $m m=S S$ & $T$ & \\
\hline $823 \mathrm{~B}-23 \mathrm{X}-1$ & 75 & 76 & 209.9 & 1.95 & 0.9 & $\mathrm{VF}$ & silt & $m m=S S$ & $T$ & \\
\hline $823 \mathrm{~B}-23 \mathrm{X}-1$ & 79 & 80 & 209.9 & 1.95 & 1.2 & VF & silt & mm…SS & $T$ & \\
\hline $823 \mathrm{~B}-23 \mathrm{X}-1$ & 81 & 82 & 209.9 & 1.95 & 1.1 & $\mathrm{~F}$ & silt & mm...SS & $T$ & \\
\hline $823 \mathrm{~B}-23 \mathrm{X}-1$ & 86 & 87 & 210 & 1.95 & 0.6 & VF & & & $\mathrm{T}$ & \\
\hline $823 \mathrm{~B}-23 \mathrm{X}-2$ & 4 & 5 & 210.7 & 1.97 & 0.2 & F-VF & & 쓰..SS & $T$ & \\
\hline $823 \mathrm{~B}-23 \mathrm{X}-2$ & 14 & 15 & 210.8 & 1.97 & 0.6 & VF & silt & mи…SS & $T$ & \\
\hline $823 \mathrm{~B}-23 \mathrm{X}-2$ & 22 & 27 & 210.9 & 1.98 & 5 & $\mathrm{~F}$ & VF & ми…SS & $T$ & \\
\hline $823 \mathrm{~B}-23 \mathrm{X}-2$ & 31 & 49 & 211.1 & 1.98 & 19 & F & F-M & мn…SS & $T$ & ? \\
\hline $823 \mathrm{~B}-23 \mathrm{X}-2$ & 62 & 65 & 211.3 & 1.99 & 2.5 & & & mm...SS & $\mathrm{T}$ & \\
\hline $823 B-23 X-2$ & 66 & 69 & 211.3 & 1.99 & 3.3 & VF & & & $T$ & \\
\hline $823 \mathrm{~B}-23 \mathrm{X}-2$ & 96 & 99 & 211.6 & 1.99 & 2.5 & $\mathrm{VF} / \mathrm{M}$ & mud & & $T$ & ? \\
\hline $823 B-23 X-2$ & 108 & 109 & 211.7 & 2 & 0.5 & $\mathrm{~F}(\mathrm{M})$ & mud & $m$ m...SS & $T$ & \\
\hline $823 \mathrm{~B}-23 \mathrm{X}-2$ & 113 & 114 & 211.7 & 2 & 1.2 & F/silt & & & $T$ & \\
\hline $823 \mathrm{~B}-23 \mathrm{X}-2$ & 146 & 147 & 212.1 & 2.01 & 0.1 & VF & mud & мm…SS & $T$ & \\
\hline $823 \mathrm{~B}-23 \mathrm{X}-3$ & 29 & 31 & 212.4 & 2.02 & 1.7 & $\mathrm{VF} / \mathrm{F}$ & silt & & $T$ & \\
\hline $823 \mathrm{~B}-23 \mathrm{X}-3$ & 34 & 35 & 212.5 & 2.02 & 0.5 & VF & mud & mm...SS & $\mathrm{T}$ & \\
\hline $823 \mathrm{~B}-23 \mathrm{X}-3$ & 37 & 38 & 212.5 & 2.02 & 0.8 & VF & mud & mm...SS & $T$ & \\
\hline $823 \mathrm{~B}-23 \mathrm{X}-3$ & 41 & 42 & 212.5 & 2.02 & 0.9 & VF & mud & mm...SS & $T$ & \\
\hline $823 \mathrm{~B}-23 \mathrm{X}-3$ & 60 & 61 & 212.7 & 2.03 & 0.2 & VF & mud & mm...SS & $\mathrm{T}$ & \\
\hline $823 \mathrm{~B}-23 \mathrm{X}-3$ & 113 & 150 & 213.6 & 2.05 & 37 & mud & $11.5 \mathrm{~cm}$ & 几MSBU & $\mathrm{DF} / 2$ & \\
\hline
\end{tabular}


Appendix A (continued).

\begin{tabular}{|c|c|c|c|c|c|c|c|c|c|c|c|}
\hline Sample & Top $(\mathrm{cm})$ & $\begin{array}{c}\text { Bottom } \\
\text { (cm) }\end{array}$ & Depth (m) & $\begin{array}{c}\text { Age } \\
\text { (ma) }\end{array}$ & Thickness (cm) & Texture Base & Texture Top & Mud cap & $\begin{array}{l}\text { Sedimentary } \\
\text { Structure }\end{array}$ & $\begin{array}{l}\text { Depositional } \\
\text { Mechanism }\end{array}$ & $?$ \\
\hline $823 \mathrm{~B}-23 \mathrm{X}-4$ & 0 & 134 & 214.9 & 2.09 & 171 & mud & $17 \mathrm{~cm}$ & & 几MSBV & DF & \\
\hline $823 \mathrm{~B}-23 \mathrm{X}-4$ & 134 & 137 & 215 & 2.09 & 3.6 & VF-M & & & & $\mathrm{T}$ & \\
\hline 823B-23X-5 & 0 & 4 & 215.1 & 2.09 & 3.7 & VF & silt & & & $\mathrm{T}$ & \\
\hline $823 \mathrm{~B}-23 \mathrm{X}-5$ & 13 & 15 & 215.3 & 2.1 & 1.5 & VF & silt & & & $T$ & \\
\hline 823B-23X-5 & 21 & 26 & 215.4 & 2.1 & 2.7 & VF & silt & & mm…SS & T & \\
\hline $823 \mathrm{~B}-23 \mathrm{X}-5$ & 42 & 47 & 215.6 & 2.1 & 4 & VF & silt & & mn…SS & $\mathrm{T}$ & \\
\hline 823B-23X-5 & 54 & 81 & 215.9 & 2.11 & 0 & VF & & & mn…SS & $\mathrm{T}$ & ? \\
\hline $823 \mathrm{~B}-23 \mathrm{X}-5$ & 112 & 113 & 216.2 & 2.12 & 1.3 & VF & silt & & mn…SS & $T$ & \\
\hline 823B-23X-5 & 122 & 123 & 216.3 & 2.13 & 0.4 & VF & silt & & mи…SS & $\mathrm{T}$ & \\
\hline 823B-23X-6 & 14 & 16 & 216.8 & 2.14 & 1.6 & VF & silt & & мm…SS & $\mathrm{T}$ & \\
\hline 823B-23X-6 & 29 & 30 & 216.9 & 2.14 & 0.9 & VF & silt & & mm…SS & $\mathrm{T}$ & \\
\hline $823 \mathrm{~B}-23 \mathrm{X}-6$ & 33 & 34 & 216.9 & 2.14 & 0.6 & VF & silt & & ми…SS & $\mathrm{T}$ & \\
\hline 823B-23X-6 & 39 & 40 & 217 & 2.14 & 0.2 & VF & silt & & mи…SS & $\mathrm{T}$ & \\
\hline $823 B-23 X-6$ & 43 & 45 & 217.1 & 2.15 & 1.3 & VF & silt & & ми…SS & T & \\
\hline 823B-23X-6 & 48 & 49 & 217.1 & 2.15 & 1.3 & silt/VF & VF & & SS & $\mathrm{T}$ & \\
\hline 823B-23X-6 & 54 & 55 & 217.2 & 2.15 & 0.7 & F & silt & & ми…SS & $\mathrm{T}$ & \\
\hline $823 \mathrm{~B}-23 \mathrm{X}-6$ & 73 & 75 & 217.4 & 2.15 & 1.5 & F & silt & & \#SS & T & \\
\hline 823B-23X-6 & 81 & 84 & 217.5 & 2.16 & 2.5 & $\mathrm{~F}$ & silt & & ми…SS & $\mathrm{T}$ & \\
\hline 823B-23X-6 & 91 & 95 & 217.6 & 2.16 & 1.6 & M & $\mathrm{VF}$ & & mи…SS & $\mathrm{T}$ & \\
\hline 823B-23X-6 & 103 & 108 & 217.7 & 2.16 & 3.5 & VF & silt & & мn…SS & $\mathrm{T}$ & \\
\hline 823B-23X-6 & 113 & 114 & 217.7 & 2.16 & 0.2 & VF & silt & & мm…SS & $T$ & \\
\hline $823 B-23 X-6$ & 121 & 122 & 217.8 & 2.17 & 0.5 & VF & silt & & mm...SS & $\mathrm{T}$ & \\
\hline $823 B-23 X-6$ & 124 & 130 & 217.9 & 2.17 & 0 & $\mathrm{~F}$ & VF & & mn…SS & $\mathrm{T}$ & \\
\hline $823 \mathrm{~B}-24 \mathrm{X}-1$ & 103 & 107 & 219.8 & 2.22 & 0.6 & VF & silt & & ми… & $T$ & \\
\hline $823 \mathrm{~B}-24 \mathrm{X}-1$ & 105 & 107 & 219.8 & 2.22 & 1.3 & $\mathrm{~F}$ & VF & & ми… & $\mathrm{T}$ & \\
\hline 823B-24X-1 & 112 & 113 & 219.8 & 2.22 & 0.8 & $\mathrm{~F}$ & VF & & ми… & $\mathrm{T}$ & \\
\hline $823 \mathrm{~B}-24 \mathrm{X}-2$ & 60 & 61 & 220.8 & 2.25 & 0.4 & VF & silt & & ‥ & $\mathrm{T}$ & \\
\hline $823 B-24 X-2$ & 64 & 65 & 220.9 & 2.25 & 0.9 & VF & silt & & ‥ & $\mathrm{T}$ & \\
\hline 823B-24X-2 & 81 & 90 & 221.1 & 2.26 & 8.8 & $\mathrm{~F}$ & VF & & 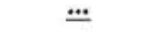 & $\mathrm{T}$ & \\
\hline 823B-24X-2 & 102 & 106 & 221.3 & 2.26 & 3.5 & VF-silt & & & & $T$ & \\
\hline 823B-24X-2 & 108 & 110 & 221.3 & 2.26 & 1.1 & VF-silt & & & $\mathrm{mm}$ & $\mathrm{T}$ & \\
\hline 823B-24X-2 & 111 & 112 & 221.3 & 2.26 & 1.2 & VF-silt & & & & $\mathrm{T}$ & \\
\hline $823 \mathrm{~B}-24 \mathrm{X}-3$ & 14 & 32 & 222 & 2.28 & 17 & VF & F & & $\ldots$ & $\mathrm{T}$ & \\
\hline $823 B-24 X-3$ & 68 & 70 & 222.4 & 2.29 & 2.2 & VF & & & & $\mathrm{T}$ & \\
\hline 823B-24X-3 & 122 & 126 & 223 & 2.3 & 3.8 & VF(F-M) & & & & $T$ & \\
\hline $823 \mathrm{~B}-24 \mathrm{X}-3$ & 145 & 149 & 223.2 & 2.3 & 4.1 & F & VF & & ...SS & $T$ & \\
\hline $823 \mathrm{~B}-24 \mathrm{X}-4$ & 41 & 51 & 223.7 & 2.3 & 9.5 & $\mathrm{~F}$ & silt & & ‥ & $T$ & \\
\hline $823 \mathrm{~B}-24 \mathrm{X}-4$ & 106 & 107 & 224.3 & 2.31 & 1.4 & VF & silt & & мm…SS & $T$ & \\
\hline $823 \mathrm{~B}-24 \mathrm{X}-4$ & 108 & 110 & 224.3 & 2.31 & 2.1 & VF & silt & & мm…SS & $\mathrm{T}$ & \\
\hline $823 \mathrm{~B}-24 \mathrm{X}-4$ & 112 & 113 & 224.3 & 2.31 & 0.8 & VF & silt & & мп…SS & $\mathrm{T}$ & \\
\hline $823 \mathrm{~B}-24 \mathrm{X}-4$ & 114 & 116 & 224.4 & 2.31 & 2.5 & VF & silt & & мп…SS & $\mathrm{T}$ & \\
\hline $823 \mathrm{~B}-24 \mathrm{X}-5$ & 18 & 71 & 225.4 & 2.32 & 1.7 & $\mathrm{~F}$ & silt & & мm…SS & $\mathrm{T}$ & \\
\hline $823 \mathrm{~B}-24 \mathrm{X}-0$ & 7 & 8 & 226 & 2.32 & 1 & VF & silt & & мn…SS & $\mathrm{T}$ & \\
\hline $823 \mathrm{~B}-24 \mathrm{X}-0$ & 21 & 22 & 226.1 & 2.33 & 0.8 & VF & silt & & ми…SS & $\mathrm{T}$ & \\
\hline $823 \mathrm{~B}-25 \mathrm{X}-1$ & 31 & 33 & 228.3 & 2.35 & 1 & VF & silt & & мm…SS & $\mathrm{T}$ & \\
\hline 823B-25X-1 & 34 & 35 & 228.4 & 2.35 & 1 & VF & silt & & мm…SS & $\mathrm{T}$ & \\
\hline 823B-25X-1 & 49 & 51 & 228.5 & 2.35 & 2 & $\mathrm{M} / \mathrm{mud}$ & & & & $\mathrm{T}$ & ? \\
\hline 823B-25X-1 & 109 & 110 & 229.1 & 2.35 & 1.7 & M & VF & & mm…SS & $T$ & \\
\hline $823 \mathrm{~B}-25 \mathrm{X}-1$ & 118 & 121 & 229.2 & 2.35 & 3 & M & VF & & min...SS & $\mathrm{T}$ & \\
\hline $823 \mathrm{~B}-25 \mathrm{X}-1$ & 143 & 144 & 229.4 & 2.36 & 0.7 & VF/silt & & & мm…SS & $\mathrm{T}$ & \\
\hline $823 \mathrm{~B}-25 \mathrm{X}-2$ & 26 & 37 & 229.8 & 2.36 & 26 & $\mathrm{~F} / \mathrm{M}$ & VF/silt & & mm…SS & $\mathrm{T}$ & \\
\hline $823 \mathrm{~B}-25 \mathrm{X}-2$ & 64 & 71 & 230.2 & 2.36 & 7 & $\mathrm{~F}$ & VF/silt & & мн…SS & $\mathrm{T}$ & \\
\hline $823 \mathrm{~B}-25 \mathrm{X}-2$ & 81 & 95 & 230.5 & 2.37 & 14.8 & $\mathrm{~F}$ & VF/silt & & mи…SS & $\mathrm{T}$ & \\
\hline $823 \mathrm{~B}-25 \mathrm{X}-2$ & 128 & 140 & 230.9 & 2.37 & 12 & (C)M & VF & & мm…SS & $\mathrm{T}$ & \\
\hline $823 \mathrm{~B}-25 \mathrm{X}-3$ & 0 & 5 & 231.1 & 2.37 & 4.3 & VF & & & & $\mathrm{T}$ & $?$ \\
\hline $823 \mathrm{~B}-25 \mathrm{X}-3$ & 14 & 48 & 231.5 & 2.38 & 45 & $\mathrm{~F} / \mathrm{VF}$ & & & & $\mathrm{T}$ & $?$ \\
\hline $823 \mathrm{~B}-25 \mathrm{X}-3$ & 62 & 70 & 231.7 & 2.38 & 9 & VF & silt & mud & & & $?$ \\
\hline $823 \mathrm{~B}-25 \mathrm{X}-3$ & 106 & 110 & 232.1 & 2.38 & 1.1 & $\mathrm{~F} / \mathrm{VF}$ & VF & & sm...SS & $T$ & \\
\hline $823 \mathrm{~B}-25 \mathrm{X}-3$ & 120 & 136 & 232.4 & 2.38 & 15 & $\mathrm{~F} / \mathrm{VF}$ & VF & & mm...SS & & $?$ \\
\hline $823 \mathrm{~B}-25 \mathrm{X}-4$ & 10 & 11 & 232.6 & 2.39 & 1 & VF & silt & & ми…SS & $\mathrm{T}$ & \\
\hline $823 \mathrm{~B}-25 \mathrm{X}-4$ & 34 & 39 & 232.9 & 2.39 & 5.2 & $\mathrm{~F} / \mathrm{M}$ & $\mathrm{VF} /$ silt & & ми…SS & $\mathrm{T}$ & \\
\hline $823 B-25 X-4$ & 76 & 92 & 233.4 & 2.39 & 15 & $\mathrm{~F}$ & & & & $T$ & $?$ \\
\hline $823 \mathrm{~B}-25 \mathrm{X}-5$ & 2 & 5 & 234.1 & 2.4 & 2.6 & VF & silt & & ми…SS & $\mathrm{T}$ & \\
\hline $823 \mathrm{~B}-25 \mathrm{X}-5$ & 11 & 15 & 234.2 & 2.4 & 3.7 & VF & silt & & ми…SS & $\mathrm{T}$ & \\
\hline $823 B-25 X-5$ & 54 & 60 & 234.6 & 2.41 & 4.5 & $\mathrm{~F}$ & VF/silt & & mи…SS & $\mathrm{T}$ & \\
\hline
\end{tabular}


Appendix A (continued).

\begin{tabular}{|c|c|c|c|c|c|c|c|c|c|c|c|}
\hline Sample & Top (cm) & $\begin{array}{c}\text { Bottom } \\
(\mathrm{cm})\end{array}$ & Depth (m) & $\begin{array}{l}\text { Age } \\
\text { (ma) }\end{array}$ & Thickness $(\mathrm{cm})$ & Texture Base & Texture Top & Mud cap & $\begin{array}{l}\text { Sedimentary } \\
\text { Structure }\end{array}$ & $\begin{array}{l}\text { Depositional } \\
\text { Mechanism }\end{array}$ & ? \\
\hline $823 \mathrm{~B}-25 \mathrm{X}-5$ & 100 & 101 & 235 & 2.41 & 0.6 & $\mathrm{~F}$ & silt & & мn…5S & $T$ & \\
\hline $823 \mathrm{~B}-25 \mathrm{X}-5$ & 105 & 122 & 235.2 & 2.41 & 16.5 & $\mathrm{~F}$ & silt & & 쓰…SS & $\mathrm{T}$ & \\
\hline $823 B-25 X-5$ & 132 & 134 & 235.3 & 2.41 & 0.9 & VF & silt & & ...SS & $\mathrm{T}$ & \\
\hline $823 B-25 X-5$ & 140 & 144 & 235.4 & 2.41 & 3.6 & VF & silt & & mm...SS & $\mathrm{T}$ & \\
\hline $823 \mathrm{~B}-25 \mathrm{X}-6$ & 4 & 5 & 235.6 & 2.41 & 1.2 & VF & silt & & ...SS & $\mathrm{T}$ & \\
\hline $823 \mathrm{~B}-25 \mathrm{X}-6$ & 11 & 15 & 235.7 & 2.42 & 4.8 & $\mathrm{~F}$ & VF/silt & & & $\mathrm{T}$ & \\
\hline $823 \mathrm{~B}-25 \mathrm{X}-6$ & 39 & 41 & 235.9 & 2.42 & 2.2 & $\mathrm{~F}$ & VF/silt & & & $\mathrm{T}$ & \\
\hline $823 \mathrm{~B}-25 \mathrm{X}-6$ & 50 & 55 & 236.1 & 2.42 & 4.4 & F & VF/silt & & & $\mathrm{T}$ & \\
\hline $823 \mathrm{~B}-25 \mathrm{X}-6$ & 60 & 64 & 236.1 & 2.42 & 4 & $\mathrm{~F}$ & silt/VF & & & $T$ & \\
\hline $823 B-25 X-6$ & 64 & 74 & 236.2 & 2.42 & 1 & VF & silt/mud & & mm...SS & $T$ & \\
\hline 823B-25X-6 & 86 & 90 & 236.4 & 2.43 & 4 & $\mathrm{~F}$ & VF/silt & & mm...SS & $\mathrm{T}$ & \\
\hline 823B-25X-6 & 106 & 111 & 236.6 & 2.43 & 4.8 & F & VF/silt & & mm...SS & $\mathrm{T}$ & \\
\hline 823B-25X-6 & 115 & 129 & 236.8 & 2.43 & 14.1 & F & VF/silt & & mm...SS & $\mathrm{T}$ & \\
\hline $823 \mathrm{~B}-25 \mathrm{X}-6$ & 139 & 139 & 236.9 & 2.44 & 2.8 & $\mathrm{~F}$ & VF/silt & & mm...SS & $\mathrm{T}$ & \\
\hline $823 B-25 X-6$ & 146 & 148 & 237 & 2.44 & 1.8 & VF & silt & & mm....SS & $\mathrm{T}$ & \\
\hline $823 \mathrm{~B}-25 \mathrm{X}-7$ & 5 & 9 & 237.1 & 2.44 & 3.9 & $\mathrm{~F}$ & VF/silt & & mm...SS & $\mathrm{T}$ & \\
\hline $823 \mathrm{~B}-25 \mathrm{X}-7$ & 19 & 24 & 237.2 & 2.44 & 5.2 & $\mathrm{~F}$ & VF/silt & & mm...SS & $\mathrm{T}$ & \\
\hline $823 \mathrm{~B}-25 \mathrm{X}-7$ & 27 & 28 & 237.3 & 2.44 & 0.8 & VF & mud & & $\ldots 55$ & $\mathrm{~T}$ & \\
\hline $823 \mathrm{~B}-25 \mathrm{X}-0$ & 18 & 24 & 237.6 & 2.45 & 6 & $\mathrm{~F}$ & $\mathrm{VF} / \mathrm{mud}$ & & SSS & $T$ & \\
\hline $823 \mathrm{~B}-25 \mathrm{X}-0$ & 28 & 30 & 237.7 & 2.45 & 1.3 & $\mathrm{~F}$ & VF & & & $\mathrm{T}$ & \\
\hline $823 \mathrm{~B}-25 \mathrm{X}-0$ & 41 & 42 & 237.8 & 2.46 & 0.4 & M & F & & & $\mathrm{T}$ & \\
\hline $823 \mathrm{~B}-26 \mathrm{X}-1$ & 21 & 22 & 237.9 & 2.46 & 1.5 & M & mud & & & $\mathrm{T}$ & ? \\
\hline $823 \mathrm{~B}-26 \mathrm{X}-1$ & 137 & 141 & 239.1 & 2.49 & 4 & M & VF & & mm…SS & $\mathrm{T}$ & \\
\hline $823 \mathrm{~B}-26 \mathrm{X}-1$ & 144 & 146 & 239.2 & 2.49 & 3.5 & F & silt & & $m m \cdots=义 S S$ & $\mathrm{~T}$ & \\
\hline $823 \mathrm{~B}-26 \mathrm{X}-2$ & 0 & 150 & 240.7 & 2.52 & 150 & (C) $M / F$ & VF & & $I N_{m n} \ldots S S \equiv$ & $s$ & \\
\hline $823 \mathrm{~B}-26 \mathrm{X}-3$ & 10 & 14 & 240.8 & 2.52 & 3.8 & $\mathrm{M}$ & VF & & IN mm $\ldots$ SS & $\mathrm{T}$ & \\
\hline $823 \mathrm{~B}-26 \mathrm{X}-3$ & 24 & 27 & 241 & 2.53 & 3.5 & $\mathrm{~F}$ & VF & & IN mи … SS & $\mathrm{T}$ & \\
\hline $823 \mathrm{~B}-26 \mathrm{X}-3$ & 60 & 62 & 241.3 & 2.53 & 2.3 & F & VF & & mm...SS & $\mathrm{T}$ & \\
\hline $823 \mathrm{~B}-26 \mathrm{X}-3$ & 75 & 76 & 241.5 & 2.54 & 0.9 & F & VF & & sm...SS & $\mathrm{T}$ & \\
\hline 823B- $26 \mathrm{X}-3$ & 77 & 110 & 241.8 & 2.54 & 33 & & & & IN mm SS & s & \\
\hline $823 \mathrm{~B}-26 \mathrm{X}-4$ & 35 & 45 & 242.7 & 2.56 & 9.3 & F & VF & & m....SS & $\mathrm{T}$ & \\
\hline 823B- $26 \mathrm{X}-4$ & 55 & 58 & 242.8 & 2.57 & 2 & $\mathrm{~F}$ & VF & & sm $\cdots=5 S$ & $\mathrm{~T}$ & \\
\hline $823 \mathrm{~B}-26 \mathrm{X}-4$ & 64 & 68 & 242.9 & 2.57 & 3.8 & VF & & & mи…SS & $\mathrm{T}$ & \\
\hline $823 \mathrm{~B}-26 \mathrm{X}-4$ & 69 & 73 & 242.9 & 2.57 & 3 & VF & & & $\bar{\cdots} \bumpeq \cdots$ & S & \\
\hline $823 \mathrm{~B}-26 \mathrm{X}-4$ & 75 & 86 & 243.1 & 2.57 & 10 & $\mathrm{~F}$ & VF/silt & & & $\mathrm{T}$ & \\
\hline $823 \mathrm{~B}-26 \mathrm{X}-4$ & 99 & 103 & 243.2 & 2.58 & 4.2 & F & VF/silt & & mm...SS & $\mathrm{T}$ & \\
\hline $823 \mathrm{~B}-26 \mathrm{X}-4$ & 113 & 118 & 243.4 & 2.58 & 5.7 & F & VF/silt & & m...ss & $\mathrm{T}$ & \\
\hline $823 \mathrm{~B}-26 \mathrm{X}-4$ & 120 & 130 & 243.5 & 2.58 & 10 & F & VF/silt & & mm...SS & $\mathrm{T}$ & \\
\hline $823 B-26 X-5$ & 6 & 41 & 244.1 & 2.6 & 34.5 & $\mathrm{~F} / \mathrm{M}$ & VF/silt & & $m m \cdots=S S$ & $\mathrm{~T}$ & \\
\hline $823 B-26 X-5$ & 52 & 57 & 244.3 & 2.6 & 2.5 & VF & mud & & mmㄹ= & $T$ & \\
\hline $823 \mathrm{~B}-26 \mathrm{X}-5$ & 74 & 80 & 244.5 & 2.6 & 2.2 & VF & mud & & мим $\cdots=$ & $\mathrm{T}$ & \\
\hline $823 \mathrm{~B}-26 \mathrm{X}-5$ & 95 & 150 & 245.2 & 2.61 & 55 & & & & & $\mathrm{~S} / 2$ & ? \\
\hline $823 B-26 X-6$ & 0 & 150 & 246.7 & 2.62 & 150 & & & & IN & $\mathrm{s} / 2$ & $?$ \\
\hline $823 B-26 X-7$ & 32 & 33 & 247 & 2.62 & 1 & VF & & & sm… & $\mathrm{S} / \mathrm{T}$ & \\
\hline $823 B-26 X-7$ & 44 & 45 & 247.2 & 2.62 & 0.9 & VF & & & mm... & $\mathrm{T}$ in $\mathrm{S}$ & \\
\hline $823 \mathrm{~B}-27 \mathrm{X}-1$ & 0 & 72 & 248 & 2.62 & 72 & & & & IN & $\mathrm{s} / 2$ & \\
\hline $823 \mathrm{~B}-27 \mathrm{X}-2$ & 112 & 121 & 250 & 2.64 & 6.5 & C & VF & & IN m $\cdots$. SS & $\mathrm{T}$ in $\mathrm{S}$ & \\
\hline $823 B-27 X-2$ & 131 & 135 & 250.2 & 2.64 & 6.5 & $\mathrm{~F}$ & VF/silt & & mm...SS & $\mathrm{T}$ in $\mathrm{S}$ & \\
\hline $823 B-27 X-2$ & 0 & 150 & 250.3 & 2.64 & 150 & & & & IN & $\mathrm{S} / 2$ & \\
\hline $823 \mathrm{~B}-27 \mathrm{X}-3$ & 11 & 16 & 250.5 & 2.64 & 1.4 & $\mathrm{~F}$ & VF & & IN mm ... SS & $\mathrm{T}$ in $\mathrm{S}$ & \\
\hline $823 \mathrm{~B}-27 \mathrm{X}-3$ & 0 & 150 & 251.8 & 2.65 & 150 & & & & IN OT & $\mathrm{S} / 2$ & \\
\hline $823 B-27 X-4$ & 8 & 14 & 251.9 & 2.65 & 5 & $\mathrm{~F}$ & VF & & IN m m $\ldots$ SS & $\mathrm{T}$ in $\mathrm{S}$ & \\
\hline $823 \mathrm{~B}-27 \mathrm{X}-4$ & 14 & 20 & 252 & 2.65 & 5 & $\mathrm{~F} / \mathrm{M}$ & VF/silt & mud & IN $\mathrm{mm} \ldots$ SS & $\mathrm{T}$ in $\mathrm{S}$ & \\
\hline $823 \mathrm{~B}-27 \mathrm{X}-6$ & 0 & 13 & 254.9 & 2.67 & 6 & $\mathrm{M}$ & VF/silt & & IN $\mathrm{mm} \ldots$ SS & $\mathrm{T}$ in $\mathrm{S}$ & \\
\hline $823 B-27 X-6$ & 22 & 41 & 255.2 & 2.67 & 0.9 & VF & F & & m… & $T$ in $S$ & \\
\hline $823 \mathrm{~B}-27 \mathrm{X}-6$ & 107 & 117 & 256 & 2.68 & 4 & $\mathrm{~F}$ & VF & & mm...SS & $\mathrm{T}$ in $\mathrm{S}$ & \\
\hline $823 \mathrm{~B}-27 \mathrm{X}-6$ & 118 & 123 & 256 & 2.68 & 4.8 & $\mathrm{~F}$ & VF & & mm...SS & $\mathrm{T}$ in $\mathrm{S}$ & \\
\hline $823 B-27 X-6$ & 0 & 136 & 256.2 & 2.68 & 136 & & & & IN m $\cdots$...SS & $\mathrm{S} / 2$ & \\
\hline $823 \mathrm{~B}-27 \mathrm{X}-6$ & 0 & 136 & 256.2 & 2.68 & 1086 & & & & $I N \mathrm{Nm} \cdots$ SS & $\mathrm{S}$ & \\
\hline $823 B-27 X-7$ & 11 & 14 & 256.4 & 2.68 & 1.8 & $\mathrm{~F}$ & silt & & mm…SS & $\mathrm{T}$ & \\
\hline $823 \mathrm{~B}-27 \mathrm{X}-7$ & 15 & 16 & 256.5 & 2.68 & 1 & VF & silt & & mm…SS & $\mathrm{T}$ & \\
\hline $823 B-27 X-7$ & 17 & 18 & 256.5 & 2.68 & 0.7 & $\mathrm{~F}$ & VF & & mm...SS & $\mathrm{T}$ & \\
\hline $823 B-27 X-7$ & 22 & 23 & 256.5 & 2.68 & 1 & F & VF & & mm....SS & $\mathrm{T}$ & \\
\hline $823 B-27 X-7$ & 55 & 61 & 256.9 & 2.68 & 5.7 & F & VF/silt & & mm…SS & $\mathrm{T}$ & \\
\hline $823 \mathrm{~B}-27 \mathrm{X}-7$ & 67 & 69 & 257 & 2.68 & 1.2 & F & VF/silt & & мm…SS & $\mathrm{T}$ & \\
\hline
\end{tabular}


Appendix A (continued).

\begin{tabular}{|c|c|c|c|c|c|c|c|c|c|c|c|}
\hline Sample & Top (cm) & $\begin{array}{c}\text { Bottom } \\
(\mathrm{cm})\end{array}$ & Depth (m) & $\begin{array}{l}\text { Age } \\
\text { (ma) }\end{array}$ & Thickness $(\mathrm{cm})$ & Texture Base & Texture Top & Mud cap & $\begin{array}{c}\text { Sedimentary } \\
\text { Structure }\end{array}$ & $\begin{array}{l}\text { Depositional } \\
\text { Mechanism }\end{array}$ & ? \\
\hline $823 \mathrm{~B}-27 \mathrm{X}-7$ & 78 & 79 & 257.1 & 2.68 & 0.3 & VF & mud & & mи…5S & $T$ & \\
\hline $823 B-27 X-7$ & 108 & 109 & 257.1 & 2.68 & 0.5 & $\mathrm{~F}$ & VF/silt & & m…SS & $T$ & \\
\hline $823 \mathrm{~B}-27 \mathrm{X}-7$ & 123 & 125 & 257.1 & 2.68 & 2.8 & F & VF/silt & & мm…SS & $\mathrm{T}$ & \\
\hline $823 \mathrm{~B}-27 \mathrm{X}-0$ & 1 & 2 & 257.1 & 2.68 & 0.3 & VF & & & & $\mathrm{T}$ & \\
\hline $823 B-27 X-0$ & 10 & 14 & 257.1 & 2.68 & 4.5 & $\mathrm{~F}$ & VF/silt & & ...SS & $\mathrm{T}$ & \\
\hline $823 \mathrm{~B}-28 \mathrm{X}-1$ & 5 & 8 & 257.1 & 2.68 & 2.5 & VF & silt & & ㅅ․…SS & $\mathrm{T}$ & \\
\hline $823 \mathrm{~B}-28 \mathrm{X}-1$ & 18 & 23 & 257.2 & 2.68 & 1.5 & $\mathrm{~F}$ & VF/silt & & mm...SS & $\mathrm{T}$ & \\
\hline $823 B-28 X-1$ & 29 & 31 & 257.3 & 2.68 & 1.7 & VF & silt & & 스…SS & $\mathrm{T}$ & \\
\hline $823 \mathrm{~B}-28 \mathrm{X}-1$ & 39 & 40 & 257.4 & 2.69 & 0.4 & VF & silt & & mm...SSS & $\mathrm{T}$ & \\
\hline $823 B-28 X-1$ & 43 & 47 & 257.5 & 2.69 & 3.5 & $\mathrm{~F} / \mathrm{M}$ & $\mathrm{VF} /$ silt & & mn…SS & $\mathrm{T}$ & \\
\hline $823 \mathrm{~B}-28 \mathrm{X}-1$ & 48 & 50 & 257.5 & 2.69 & 2 & $\mathrm{~F}$ & $\mathrm{VF} /$ silt & & mm...SS & $\mathrm{T}$ & \\
\hline $823 \mathrm{~B}-28 \mathrm{X}-1$ & 57 & 70 & 257.7 & 2.69 & 12.9 & M & $\mathrm{VF} / \mathrm{mud}$ & & mm…SS & $\mathrm{T}$ & \\
\hline $823 \mathrm{~B}-28 \mathrm{X}-1$ & 77 & 78 & 257.8 & 2.69 & 1 & VF & silt & & & $\mathrm{T}$ & \\
\hline $823 \mathrm{~B}-28 \mathrm{X}-1$ & 80 & 81 & 257.8 & 2.69 & 1 & VF & silt & & mm…SS & $\mathrm{T}$ & \\
\hline $823 \mathrm{~B}-28 \mathrm{X}-1$ & 83 & 86 & 257.9 & 2.69 & 1.5 & VF & silt & & & $\mathrm{T}$ & \\
\hline $823 \mathrm{~B}-28 \mathrm{X}-1$ & 90 & 96 & 258 & 2.69 & 5.9 & VF & silt & & & $\mathrm{T}$ & \\
\hline $823 \mathrm{~B}-28 \mathrm{X}-1$ & 119 & 121 & 258.2 & 2.69 & 1.2 & VF & silt & & mn…SS & $\mathrm{T}$ & \\
\hline $823 \mathrm{~B}-28 \mathrm{X}-1$ & 123 & 126 & 258.3 & 2.69 & 1.5 & $\mathrm{~F} / \mathrm{VF}$ & silt & & mm…SS & $\mathrm{T}$ & \\
\hline $823 \mathrm{~B}-28 \mathrm{X}-2$ & 126 & 127 & 259.8 & 2.7 & 1 & VF & & & SS & $\mathrm{T}$ & \\
\hline $823 \mathrm{~B}-28 \mathrm{X}-2$ & 129 & 136 & 259.9 & 2.7 & 7.5 & M & VF & & мm…SS & $\mathrm{T}$ & \\
\hline $823 \mathrm{~B}-28 \mathrm{X}-3$ & 22 & 31 & 260.3 & 2.7 & 9 & M & VF & & mm...SS & $\mathrm{T}$ & \\
\hline $823 B-28 X-3$ & 64 & 65 & 260.7 & 2.71 & 0.4 & VF & mud & & mm...SS & $\mathrm{T}$ & \\
\hline $823 \mathrm{~B}-28 \mathrm{X}-3$ & 110 & 112 & 261.1 & 2.71 & 2 & $\mathrm{~F}$ & silt & & mm…SS & $T$ & \\
\hline $823 \mathrm{~B}-28 \mathrm{X}-3$ & 112 & 113 & 261.1 & 2.71 & 0.5 & $\mathrm{~F}$ & silt & & mm...SS & $\mathrm{T}$ & \\
\hline $823 \mathrm{~B}-28 \mathrm{X}-4$ & 0 & 2 & 261.5 & 2.71 & 2 & $\mathrm{~F}$ & $\mathrm{VF}$ & & 쓰…SS & $\mathrm{T}$ & \\
\hline $823 \mathrm{~B}-28 \mathrm{X}-4$ & 22 & 24 & 261.7 & 2.71 & 1.5 & M & $\mathrm{F}$ & & mu…SS & $\mathrm{T}$ & \\
\hline $823 \mathrm{~B}-28 \mathrm{X}-4$ & 36 & 44 & 261.9 & 2.72 & 7.6 & $\mathrm{~F}$ & VF & & mm...SS & $T$ & \\
\hline $823 B-28 X-4$ & 66 & 70 & 262.2 & 2.72 & 4.3 & $\mathrm{~F}$ & VF & & mn…SS & $\mathrm{T}$ & \\
\hline $823 B-28 X-4$ & 88 & 106 & 262.6 & 2.72 & 18.2 & M & $\mathrm{VF} /$ silt & & mm...SS & $\mathrm{T}$ & \\
\hline $823 \mathrm{~B}-28 \mathrm{X}-4$ & 109 & 116 & 262.7 & 2.72 & 7.2 & $\mathrm{~F}$ & $\mathrm{VF} /$ silt & & mm…SS & $\mathrm{T}$ & \\
\hline $823 \mathrm{~B}-28 \mathrm{X}-4$ & 126 & 131 & 262.8 & 2.72 & 5.8 & $\mathrm{~F}$ & VF/silt & & 쓰도S & $\mathrm{T}$ & \\
\hline $823 B-28 X-4$ & 136 & 137 & 262.9 & 2.72 & 1.1 & VF & silt & & IN & $T$ & \\
\hline $823 B-28 X-5$ & 2 & 3 & 263 & 2.72 & 1.1 & $\mathrm{~F}$ & silt & & 쓰…SS & $\mathrm{T}$ & \\
\hline $823 B-28 X-5$ & 10 & 13 & 263.1 & 2.72 & 2.7 & $\mathrm{C}(\mathrm{VC})$ & & & m…SS & $\mathrm{T}$ & \\
\hline $823 B-28 X-5$ & 45 & 49 & 263.5 & 2.73 & 4 & M & silt & & 쓰…SS & $T$ & \\
\hline $823 B-28 X-5$ & 66 & 70 & 263.7 & 2.73 & 2.3 & $\mathrm{~F}$ & silt & & 쓰…SS & $\mathrm{T}$ & \\
\hline $823 \mathrm{~B}-28 \mathrm{X}-5$ & 71 & 72 & 263.7 & 2.73 & 1.3 & $\mathrm{~F}$ & silt & & ми…SS & $T$ & \\
\hline $823 B-28 X-5$ & 84 & 85 & 263.9 & 2.73 & 1 & VF & silt & & SS & $\mathrm{T}$ & \\
\hline $823 B-28 X-5$ & 100 & 104 & 264 & 2.73 & 3.7 & $\mathrm{~F}$ & silt & & 쓰…SS & $\mathrm{T}$ & \\
\hline $823 B-28 X-5$ & 124 & 127 & 264.3 & 2.73 & 3.1 & $\mathrm{~F}$ & silt & & ми…SS & $\mathrm{T}$ & \\
\hline $823 B-28 X-6$ & 2 & 5 & 264.6 & 2.73 & 2.8 & $\mathrm{~F}$ & VF & & mm...SSS & $T$ & \\
\hline $823 \mathrm{~B}-28 \mathrm{X}-6$ & 17 & 20 & 264.7 & 2.73 & 3.1 & $\mathrm{~F}$ & VF & & mm...SS & $\mathrm{T}$ & \\
\hline $823 B-28 X-6$ & 22 & 23 & 264.7 & 2.73 & 1.1 & $\mathrm{~F}$ & $\mathrm{VF}$ & & m…SS & $T$ & \\
\hline $823 B-28 X-6$ & 104 & 105 & 265.6 & 2.74 & 1.2 & $\mathrm{~F}$ & VF & & 쓰…SS & $T$ & \\
\hline $823 \mathrm{~B}-28 \mathrm{X}-6$ & 107 & 127 & 265.8 & 2.74 & 20.3 & VF & M & & $S S \ldots{ }_{m m}$ & $T$ & \\
\hline $823 \mathrm{~B}-28 \mathrm{X}-6$ & 137 & 140 & 265.9 & 2.74 & 2.7 & $\mathrm{~F}$ & VF & & л․…SS & $T$ & \\
\hline $823 \mathrm{~B}-28 \mathrm{X}-0$ & 2 & 3 & 265.9 & 2.74 & 1 & $\mathrm{~F}$ & VF & & mm...SS & $\mathrm{T}$ & \\
\hline $823 \mathrm{~B}-28 \mathrm{X}-0$ & 6 & 7 & 266 & 2.74 & 0.8 & M & $\mathrm{F}$ & & 쓰…SS & $\mathrm{T}$ & \\
\hline $823 \mathrm{~B}-28 \mathrm{X}-0$ & 7 & 8 & 266 & 2.74 & 0.1 & M & $\mathrm{F}$ & mud & 그…SS & $\mathrm{T}$ & \\
\hline $823 \mathrm{~B}-28 \mathrm{X}-0$ & 9 & 11 & 266 & 2.74 & 2.3 & $\mathrm{~F}$ & silt & & 쓰…SS & $\mathrm{T}$ & \\
\hline $823 \mathrm{~B}-28 \mathrm{X}-0$ & 16 & 24 & 266.2 & 2.74 & 7 & M & VF & mud & m…SS & $\mathrm{T}$ & \\
\hline $823 \mathrm{~B}-29 \mathrm{X}-1$ & 4 & 5 & 266.8 & 2.75 & 0.3 & VF & silt & & 쓰…SS & $T$ & \\
\hline $823 B-29 X-1$ & 21 & 24 & 266.9 & 2.75 & 2.5 & $\mathrm{~F}$ & VF/silt & & m…SS & $T$ & \\
\hline $823 \mathrm{~B}-29 \mathrm{X}-1$ & 75 & 76 & 267.5 & 2.75 & 1.2 & $\mathrm{~F}(\mathrm{M})$ & VF/silt & & 쓰…SS & $\mathrm{T}$ & \\
\hline $823 \mathrm{~B}-29 \mathrm{X}-1$ & 99 & 102 & 267.7 & 2.75 & 2.4 & $\mathrm{~F}$ & VF/silt & & mn…SS & $T$ & \\
\hline $823 \mathrm{~B}-29 \mathrm{X}-1$ & 112 & 117 & 267.9 & 2.75 & 5.3 & F & VF/silt & & ми…SS & $T$ & \\
\hline $823 \mathrm{~B}-29 \mathrm{X}-1$ & 139 & 145 & 268.2 & 2.76 & 5 & $\mathrm{~F}$ & $\mathrm{VF} /$ silt & & mi...SS & $T$ & \\
\hline $823 \mathrm{~B}-29 \mathrm{X}-2$ & 0 & 3 & 268.2 & 2.76 & 3.3 & $\mathrm{~F}$ & VF/silt & & 쓰…SS & $\mathrm{T}$ & \\
\hline $823 \mathrm{~B}-29 \mathrm{X}-2$ & 15 & 21 & 268.4 & 2.76 & 4 & $\mathrm{~F}$ & mud & & 느…SS & $\mathrm{T}$ & \\
\hline $823 \mathrm{~B}-29 \mathrm{X}-2$ & 24 & 26 & 268.5 & 2.76 & 2 & $\mathrm{VF}$ & silt & & 그…SS & $\mathrm{T}$ & \\
\hline $823 \mathrm{~B}-29 \mathrm{X}-2$ & 33 & 37 & 268.6 & 2.76 & 3.1 & $\mathrm{~F}$ & VF & & m…SS & $\mathrm{T}$ & \\
\hline $823 \mathrm{~B}-29 \mathrm{X}-2$ & 53 & 56 & 268.8 & 2.76 & 2.7 & $\mathrm{~F}$ & VF & & m…SS & $\mathrm{T}$ & \\
\hline $823 B-29 X-2$ & 64 & 66 & 268.9 & 2.76 & 1.8 & $\mathrm{~F}$ & $\mathrm{VF}$ & & m…SS & $\mathrm{T}$ & \\
\hline $823 \mathrm{~B}-29 \mathrm{X}-2$ & 79 & 86 & 269.1 & 2.76 & 6.5 & M & VF & & mи…SS & $\mathrm{T}$ & \\
\hline $823 \mathrm{~B}-29 \mathrm{X}-2$ & 94 & 101 & 269.2 & 2.76 & 7 & $\mathrm{~F}$ & VF/silt & & миㅡㄴ.SS & $\mathrm{T}$ & \\
\hline
\end{tabular}


Appendix A (continued).

\begin{tabular}{|c|c|c|c|c|c|c|c|c|c|c|}
\hline $\begin{array}{r}\text { Sample } \\
\end{array}$ & Top $(\mathrm{cm})$ & $\begin{array}{c}\text { Bottom } \\
(\mathrm{cm})\end{array}$ & Depth $(\mathrm{m})$ & $\begin{array}{c}\text { Age } \\
\text { (ma) }\end{array}$ & Thickness (cm) & Texture Base & Texture Top Mud cap & $\begin{array}{c}\text { Sedimentary } \\
\text { Structure }\end{array}$ & $\begin{array}{l}\text { Depositional } \\
\text { Mechanism }\end{array}$ & $?$ \\
\hline $823 \mathrm{~B}-29 \mathrm{X}-3$ & 12 & 13 & 269.8 & 2.77 & 0.4 & VF & silt & mu…55 & $\mathrm{T}$ & \\
\hline $823 \mathrm{~B}-29 \mathrm{X}-3$ & 25 & 27 & 270 & 2.77 & 1.9 & $\mathrm{~F}$ & $\mathrm{VF} /$ silt & ми…SS & $\mathrm{T}$ & \\
\hline $823 \mathrm{~B}-29 \mathrm{X}-3$ & 35 & 36 & 270.1 & 2.77 & 1 & VF & silt & mи…SS & $\mathrm{T}$ & \\
\hline $823 \mathrm{~B}-29 \mathrm{X}-3$ & 53 & 54 & 270.2 & 2.77 & 0.8 & $\mathrm{~F}$ & VF & мп…SS & $\mathrm{T}$ & \\
\hline $823 \mathrm{~B}-29 \mathrm{X}-3$ & 57 & 58 & 270.3 & 2.77 & 1.2 & $\mathrm{~F}$ & & IN & $\mathrm{T}$ & \\
\hline $823 \mathrm{~B}-29 \mathrm{X}-3$ & 62 & 66 & 270.4 & 2.77 & 3.6 & $\mathrm{~F}$ & VF & mm…SS & $\mathrm{T}$ & \\
\hline $823 \mathrm{~B}-29 \mathrm{X}-3$ & 86 & 92 & 270.6 & 2.77 & 5.2 & $\mathrm{~F}$ & silt & m....SS & $\mathrm{T}$ & \\
\hline $823 \mathrm{~B}-29 \mathrm{X}-3$ & 96 & 98 & 270.7 & 2.77 & 1.8 & VF & silt & mm…SS & $T$ & \\
\hline $823 \mathrm{~B}-29 \mathrm{X}-3$ & 107 & 110 & 270.8 & 2.77 & 0.7 & VF & mud & mm...SSS & $\mathrm{T}$ & \\
\hline $823 \mathrm{~B}-29 \mathrm{X}-3$ & 139 & 142 & 271.1 & 2.78 & 3.1 & $\mathrm{~F}$ & VF & 쓰…SS & $\mathrm{T}$ & \\
\hline $823 \mathrm{~B}-29 \mathrm{X}-4$ & 23 & 27 & 271.5 & 2.78 & 3.8 & $\mathrm{~F}$ & $\mathrm{VF}$ & mm…SS & $\mathrm{T}$ & \\
\hline $823 \mathrm{~B}-29 \mathrm{X}-4$ & 39 & 45 & 271.7 & 2.78 & 5.9 & $\mathrm{~F}$ & VF & mn…SS & $\mathrm{T}$ & \\
\hline $823 B-29 X-4$ & 60 & 62 & 271.8 & 2.78 & 1.4 & $\mathrm{~F}$ & VF & mm…SS & $\mathrm{T}$ & \\
\hline $823 \mathrm{~B}-29 \mathrm{X}-4$ & 62 & 63 & 271.8 & 2.78 & 0.3 & VF & silt & mm…SS & $\mathrm{T}$ & \\
\hline $823 \mathrm{~B}-29 \mathrm{X}-4$ & 69 & 70 & 271.9 & 2.78 & 0.2 & VF & silt & mm…SS & T & \\
\hline $823 B-29 X-4$ & 72 & 73 & 271.9 & 2.78 & 0.7 & VF & silt & 쓰…SS & T & \\
\hline $823 \mathrm{~B}-29 \mathrm{X}-4$ & 76 & 82 & 272 & 2.78 & 5 & $\mathrm{~F}$ & $\mathrm{M} / \mathrm{F}$ & mm……SS & $\mathrm{T}$ & \\
\hline $823 \mathrm{~B}-29 \mathrm{X}-4$ & 88 & 93 & 272.1 & 2.78 & 5.4 & $\mathrm{~F}$ & silt & ми․ㅡSS & $T$ & \\
\hline $823 \mathrm{~B}-29 \mathrm{X}-4$ & 106 & 108 & 272.3 & 2.78 & 1.8 & VF & silt & mи…SS & $\mathrm{T}$ & \\
\hline $823 \mathrm{~B}-29 \mathrm{X}-4$ & 129 & 136 & 272.6 & 2.78 & 6.8 & $F$ & VF & mn...SS & $\mathrm{T}$ & \\
\hline $823 \mathrm{~B}-29 \mathrm{X}-5$ & 7 & 9 & 272.8 & 2.79 & 1.2 & F & VF & мm…SS & $T$ & \\
\hline $823 B-29 X-5$ & 16 & 20 & 272.9 & 2.79 & 3.7 & F & VF/silt & mm…SS & $T$ & \\
\hline $823 \mathrm{~B}-29 \mathrm{X}-5$ & 23 & 30 & 273 & 2.79 & 7 & M & VF/silt & m...SS & $T$ & \\
\hline $823 \mathrm{~B}-29 \mathrm{X}-5$ & 40 & 41 & 273.1 & 2.79 & 0.8 & VF & & mm…SS & $\mathrm{T}$ & \\
\hline $823 B-29 X-5$ & 44 & 55 & 273.3 & 2.79 & 10.8 & $\mathrm{~F} / \mathrm{M}$ & VF/silt & mm...SS & $\mathrm{T}$ & \\
\hline $823 \mathrm{~B}-29 \mathrm{X}-5$ & 67 & 70 & 273.4 & 2.79 & 2.8 & $\mathrm{~F}$ & VF & mm...SS & $T$ & \\
\hline $823 \mathrm{~B}-29 \mathrm{X}-5$ & 79 & 92 & 273.6 & 2.79 & 4.8 & M & $\mathrm{F}$ & mm...SSS & T & \\
\hline 823B-29X-5 & 105 & 109 & 273.8 & 2.79 & 0.7 & M & mud & mm...SSS & $\mathrm{T}$ & \\
\hline 823B-29X-5 & 122 & 124 & 273.9 & 2.79 & 0.3 & VF & mud & mn…SS & $\mathrm{T}$ & \\
\hline 823B-29X-5 & 128 & 130 & 274 & 2.79 & 1.8 & $\mathrm{M} / \mathrm{F}$ & & 그르sS & $\mathrm{T}$ & \\
\hline 823B-29X-5 & 134 & 137 & 274.1 & 2.79 & 3.2 & $\mathrm{~F}$ & silt & л․ㅡㄷㅗ & $\mathrm{T}$ & \\
\hline 823B-29X-5 & 149 & 150 & 274.2 & 2.8 & 0.5 & $\mathrm{~F}$ & & & $\mathrm{~T}$ & \\
\hline 823B-29X-6 & 0 & 2 & 274.2 & 2.8 & 2 & $\mathrm{~F}(\mathrm{M})$ & & & $\mathrm{T}$ & \\
\hline $823 \mathrm{~B}-29 \mathrm{X}-6$ & 36 & 37 & 274.6 & 2.8 & 0.8 & VF & silt & & $\mathrm{T}$ & \\
\hline $823 \mathrm{~B}-29 \mathrm{X}-6$ & 51 & 53 & 274.7 & 2.8 & 1 & VF & silt & mm…SS & $\mathrm{T}$ & \\
\hline $823 \mathrm{~B}-29 \mathrm{X}-6$ & 67 & 74 & 274.9 & 2.8 & 7.3 & M & $\mathrm{F} / \mathrm{VF}$ & mm...SS & $\mathrm{T}$ & \\
\hline $823 \mathrm{~B}-29 \mathrm{X}-6$ & 111 & 117 & 275.4 & 2.8 & 6.1 & $\mathrm{~F} / \mathrm{M}$ & $\mathrm{F}$ & $\operatorname{mn} \cdots . .3 S$ & $\mathrm{~T}$ & \\
\hline $823 \mathrm{~B}-29 \mathrm{X}-6$ & 133 & 136 & 275.6 & 2.8 & 3.2 & $\mathrm{~F}$ & VF/silt & mm…SS & $\mathrm{T}$ & \\
\hline $823 \mathrm{~B}-29 \mathrm{X}-0$ & 18 & 20 & 275.9 & 2.8 & 2 & $\mathrm{~F}$ & VF/silt & mn…SS & T & \\
\hline $823 \mathrm{~B}-30 \mathrm{X}-1$ & 0 & 1 & 276.3 & 2.81 & 0.6 & VF & silt & & $\mathrm{T}$ & \\
\hline $823 \mathrm{~B}-30 \mathrm{X}-1$ & 8 & 10 & 276.4 & 2.81 & 2 & VF & silt & mn…SS & T & \\
\hline $823 \mathrm{~B}-30 \mathrm{X}-1$ & 47 & 50 & 276.8 & 2.81 & 3.3 & $\mathrm{~F}$ & $\mathrm{VF} /$ silt & mㅡㅡㅡSS & $\mathrm{T}$ & \\
\hline $823 \mathrm{~B}-30 \mathrm{X}-1$ & 54 & 56 & 276.9 & 2.81 & 2.3 & $\mathrm{~F}$ & VF & mm...SSS & $\mathrm{T}$ & \\
\hline $823 \mathrm{~B}-30 \mathrm{X}-1$ & 61 & 62 & 276.9 & 2.81 & 0.7 & VF & F & 쓰…SS & $\mathrm{T}$ & \\
\hline $823 \mathrm{~B}-30 \mathrm{X}-1$ & 77 & 78 & 277.1 & 2.81 & 0.5 & VF & F & 쓰…SS & $\mathrm{T}$ & \\
\hline $823 \mathrm{~B}-30 \mathrm{X}-1$ & 85 & 98 & 277.3 & 2.82 & 14.5 & M & & мㅜ․ $=S S$ & $\mathrm{~T}$ & \\
\hline $823 \mathrm{~B}-30 \mathrm{X}-1$ & 108 & 109 & 277.4 & 2.82 & 0.3 & VF & & & $\mathrm{T}$ & \\
\hline $823 \mathrm{~B}-30 \mathrm{X}-1$ & 135 & 139 & 277.7 & 2.82 & 4.3 & $\mathrm{~F}$ & $\mathrm{VF} /$ silt & 쓰…SS & $T$ & \\
\hline $823 \mathrm{~B}-30 \mathrm{X}-2$ & 1 & 2 & 277.8 & 2.82 & 0.5 & VF & M & mи…SS & $\mathrm{T}$ & \\
\hline $823 \mathrm{~B}-30 \mathrm{X}-2$ & 11 & 34 & 278.1 & 2.82 & 21.5 & $\mathrm{~F} / \mathrm{M}$ & VF/silt & mm $\cdots=$ SS & $\mathrm{T}$ & \\
\hline $823 \mathrm{~B}-30 \mathrm{X}-2$ & 48 & 52 & 278.3 & 2.82 & 3 & $\mathrm{~F}$ & VF & mn…SS & $\mathrm{T}$ & \\
\hline $823 \mathrm{~B}-30 \mathrm{X}-2$ & 67 & 73 & 278.5 & 2.82 & 6.5 & M & VF & $m m \cdots=S S$ & $\mathrm{~T}$ & \\
\hline $823 \mathrm{~B}-30 \mathrm{X}-2$ & 85 & 91 & 278.7 & 2.82 & 6 & M & VF & 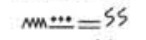 & $\mathrm{T}$ & \\
\hline $823 \mathrm{~B}-30 \mathrm{X}-2$ & 93 & 95 & 278.8 & 2.83 & 2.3 & $\mathrm{~F}$ & VF & mm…SS & $\mathrm{T}$ & \\
\hline $823 \mathrm{~B}-30 \mathrm{X}-2$ & 97 & 98 & 278.8 & 2.83 & 1.2 & M & & & $\mathrm{T}$ & \\
\hline $823 \mathrm{~B}-30 \mathrm{X}-2$ & 123 & 124 & 279 & 2.83 & 0.4 & VF & silt & ㅆㅡㅡㄷSS & $\mathrm{T}$ & \\
\hline $823 \mathrm{~B}-30 \mathrm{X}-2$ & 124 & 127 & 279.1 & 2.83 & 0.8 & $\mathrm{~F}$ & $\mathrm{VF}$ & 쓰…SS & $\mathrm{T}$ & \\
\hline 823B-30X-3 & 0 & 2 & 279.3 & 2.83 & 2 & F/VF & & & $T$ & \\
\hline $823 \mathrm{~B}-30 \mathrm{X}-3$ & 10 & 25 & 279.6 & 2.83 & 15.3 & $\mathrm{M} / \mathrm{C}$ & VF/silt & мим $\cdots=S S$ & $\mathrm{~T}$ & \\
\hline $823 \mathrm{~B}-30 \mathrm{X}-3$ & 28 & 32 & 279.6 & 2.83 & 4.2 & $\mathrm{~F}$ & VF/silt & мm…SS & $\mathrm{T}$ & \\
\hline $823 \mathrm{~B}-30 \mathrm{X}-3$ & 45 & 50 & 279.8 & 2.83 & 5 & $\mathrm{~F}$ & VF/silt & mm…SS & $\mathrm{T}$ & \\
\hline $823 \mathrm{~B}-30 \mathrm{X}-3$ & 90 & 93 & 280.2 & 2.83 & 2.8 & $\mathrm{M} / \mathrm{C}$ & VF/silt & sm $\cdots=S S$ & $\mathrm{~T}$ & \\
\hline $823 \mathrm{~B}-30 \mathrm{X}-3$ & 101 & 118 & 280.5 & 2.84 & 17.3 & M & VF/silt & мㅡ== $=S S$ & $\mathrm{~T}$ & \\
\hline $823 \mathrm{~B}-30 \mathrm{X}-3$ & 120 & 125 & 280.6 & 2.84 & 5 & $\mathrm{~F}$ & VF & мn…SS & T & \\
\hline $823 \mathrm{~B}-30 \mathrm{X}-3$ & 126 & 130 & 280.6 & 2.84 & 4.1 & F & VF & мm…SS & $T$ & \\
\hline
\end{tabular}


Appendix A (continued).

\begin{tabular}{|c|c|c|c|c|c|c|c|c|c|c|c|}
\hline Sample & Top $(\mathrm{cm})$ & $\begin{array}{l}\text { Bottom } \\
\text { (cm) }\end{array}$ & Depth (m) & $\begin{array}{l}\text { Age } \\
\text { (ma) }\end{array}$ & Thickness (cm) & Texture Base & Texture Top & Mud cap & $\begin{array}{l}\text { Sedimentary } \\
\text { Structure }\end{array}$ & $\begin{array}{l}\text { Depositional } \\
\text { Mechanism }\end{array}$ & $?$ \\
\hline $823 \mathrm{~B}-30 \mathrm{X}-4$ & 65 & 67 & 281.5 & 2.84 & 1.9 & $\mathrm{M}$ & $\mathrm{F}$ & & ми…SS & $T$ & \\
\hline $823 B-30 X-4$ & 68 & 71 & 281.5 & 2.84 & 3.1 & $\mathrm{M}$ & F & & mm…SS & T & \\
\hline 823B-30X-4 & 81 & 88 & 281.7 & 2.84 & 0 & $\mathrm{M}(\mathrm{C})$ & F & & ми․ㅡSS & $\mathrm{T}$ & \\
\hline $823 \mathrm{~B}-30 \mathrm{X}-4$ & 110 & 115 & 282 & 2.85 & 4.5 & M & & & & T & \\
\hline 823B-30X-5 & 6 & 19 & 282.5 & 2.85 & 13.5 & C & $\mathrm{M} / \mathrm{F}$ & & $m m \cdots=S S$ & T & \\
\hline 823B-30X-5 & 22 & 25 & 282.6 & 2.85 & 3 & F & VF & & ...SS & $\mathrm{T}$ & \\
\hline $823 \mathrm{~B}-30 \mathrm{X}-5$ & 45 & 46 & 282.8 & 2.85 & 1.6 & F & VF & & $\ldots S S$ & $\mathrm{~T}$ & \\
\hline $823 \mathrm{~B}-30 \mathrm{X}-5$ & 62 & 67 & 283 & 2.85 & 4.3 & M & VF & & $\mathrm{mm} \cdots$ & $\mathrm{T}$ & \\
\hline 823B-30X-5 & 102 & 103 & 283.3 & 2.86 & 0.4 & $\mathrm{~F}$ & VF & mud & sm…SS & $\mathrm{T}$ & \\
\hline $823 \mathrm{~B}-30 \mathrm{X}-5$ & 116 & 119 & 283.5 & 2.86 & 2.7 & $\mathrm{M} / \mathrm{F}$ & $F$ & & mm...SS & $\mathrm{T}$ & \\
\hline $823 \mathrm{~B}-30 \mathrm{X}-5$ & 119 & 122 & 283.5 & 2.86 & 1.2 & $\mathrm{~F}$ & mud & & мm…SS & $\mathrm{T}$ & \\
\hline $823 \mathrm{~B}-30 \mathrm{X}-5$ & 128 & 131 & 283.6 & 2.86 & 0.7 & $\mathrm{~F} / \mathrm{M}$ & mud & & mm…SS & $\mathrm{T}$ & \\
\hline $823 \mathrm{~B}-30 \mathrm{X}-5$ & 135 & 138 & 283.7 & 2.86 & 1 & $\mathrm{~F} / \mathrm{M}$ & mud & & мм… & $\mathrm{T}$ & \\
\hline $823 \mathrm{~B}-30 \mathrm{X}-5$ & 138 & 139 & 283.7 & 2.86 & 0.3 & $\mathrm{~F} / \mathrm{M}$ & mud & & мм… & $\mathrm{T}$ & \\
\hline $823 \mathrm{~B}-30 \mathrm{X}-5$ & 139 & 140 & 283.7 & 2.86 & 0.6 & $\mathrm{~F} / \mathrm{M}$ & mud & & ми… & $\mathrm{T}$ & \\
\hline $823 \mathrm{~B}-30 \mathrm{X}-5$ & 140 & 141 & 283.7 & 2.86 & 0.2 & $\mathrm{~F}$ & mud & & ми… & $\mathrm{T}$ & \\
\hline $823 \mathrm{~B}-30 \mathrm{X}-5$ & 141 & 143 & 283.7 & 2.86 & 0.8 & $\mathrm{~F} / \mathrm{M}$ & mud & & ми… & $\mathrm{T}$ & \\
\hline $823 \mathrm{~B}-30 \mathrm{X}-5$ & 143 & 145 & 283.8 & 2.86 & 1.2 & $\mathrm{M} / \mathrm{F}$ & mud & & mm…SS & $T$ & \\
\hline $823 \mathrm{~B}-30 \mathrm{X}-6$ & 0 & 2 & 283.8 & 2.86 & 1.2 & $\mathrm{~F} / \mathrm{M}$ & & & мm…SS & $T$ & \\
\hline $823 \mathrm{~B}-30 \mathrm{X}-6$ & 20 & 21 & 284 & 2.86 & 0.6 & $\mathrm{~F} / \mathrm{M}$ & & & mm...SS & $T$ & \\
\hline $823 \mathrm{~B}-30 \mathrm{X}-6$ & 31 & 32 & 284.1 & 2.86 & 1 & $\mathrm{~F} / \mathrm{M}$ & & & mm...SS & $T$ & \\
\hline $823 \mathrm{~B}-30 \mathrm{X}-6$ & 45 & 47 & 284.3 & 2.86 & 1.8 & $\mathrm{~F}$ & VF & & мм…SS & $T$ & \\
\hline $823 \mathrm{~B}-30 \mathrm{X}-0$ & 6 & 7 & 284.5 & 2.86 & 1.5 & F & VF & mud & $m m \equiv$ & $\mathrm{T}$ & \\
\hline $823 \mathrm{~B}-30 \mathrm{X}-0$ & 10 & 11 & 284.5 & 2.86 & 1 & F & VF & & мм… & $T$ & \\
\hline $823 \mathrm{~B}-30 \mathrm{X}-0$ & 22 & 26 & 284.6 & 2.86 & 4 & F & VF & & 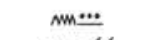 & $\mathrm{T}$ & $?$ \\
\hline $823 \mathrm{~B}-31 \mathrm{X}-2$ & 10 & 12 & 287.6 & 2.88 & 0.7 & F & silt & mud & mm...SS & $\mathrm{T}$ & \\
\hline $823 B-31 X-2$ & 17 & 25 & 287.8 & 2.88 & 1 & F & silt & mud & mm…SS & $\mathrm{T}$ & \\
\hline $823 \mathrm{~B}-31 \mathrm{X}-2$ & 34 & 43 & 287.9 & 2.89 & 3.4 & $\mathrm{~F}$ & silt & mud & mm. $\cdots S 5$ & $T$ & \\
\hline $823 \mathrm{~B}-31 \mathrm{X}-2$ & 52 & 53 & 288 & 2.89 & 0.7 & $\mathrm{~F}$ & silt & mud & $m m \cdots S S$ & $T$ & \\
\hline $823 \mathrm{~B}-31 \mathrm{X}-2$ & 110 & 117 & 288.7 & 2.89 & 2 & F & silt & mud & mm...SS & $T$ & \\
\hline $823 \mathrm{~B}-31 \mathrm{X}-2$ & 112 & 123 & 288.7 & 2.89 & 2.7 & $\mathrm{~F}$ & silt & mud & $m m \cdots=S S$ & $\mathrm{~T}$ & \\
\hline $823 \mathrm{~B}-31 \mathrm{X}-2$ & 134 & 146 & 289 & 2.89 & 1.7 & $\mathrm{~F}$ & silt & mud & Nm프SS & $\mathrm{T}$ & \\
\hline $823 \mathrm{~B}-31 \mathrm{X}-3$ & 11 & 17 & 289.2 & 2.89 & 1 & $\mathrm{~F}$ & VF & mud & mm...SS & $T$ & \\
\hline $823 \mathrm{~B}-31 \mathrm{X}-3$ & 58 & 63 & 289.6 & 2.9 & 0.4 & $\mathrm{M}$ & VF & mud & mm…SS & $T$ & \\
\hline $823 B-31 X-3$ & 86 & 93 & 289.9 & 2.9 & 8 & $\mathrm{~F} / \mathrm{VF}$ & mud & & $\mathbb{I N} \Omega$ & $\mathrm{S}$ & $?$ \\
\hline 823B-31X-3 & 93 & 96 & 290 & 2.9 & 0.8 & F & mud & & mm…SS & $\mathrm{T}$ & \\
\hline $823 B-31 X-3$ & 100 & 101 & 290 & 2.9 & 0.2 & $\mathrm{VF} /$ silt & mud & & 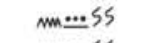 & $\mathrm{T}$ & \\
\hline $823 B-31 X-3$ & 123 & 130 & 290.3 & 2.9 & 0.7 & F & VF & mud & mm...SS & $\mathrm{T}$ & $?$ \\
\hline $823 B-31 X-3$ & 130 & 138 & 290.4 & 2.9 & 3 & $\mathrm{~F}$ & VF & mud & $m m \cdots 5 S$ & $\mathrm{~T}$ & \\
\hline $823 B-31 X-4$ & 36 & 39 & 290.9 & 2.91 & 2 & $\mathrm{~F} / \mathrm{M}$ & $\mathrm{F}$ & mud & mm...SS & $\mathrm{T}$ & \\
\hline $823 B-31 X-4$ & 63 & 67 & 291.2 & 2.91 & 0.8 & $\mathrm{~F}$ & mud & & mm...SS & T & \\
\hline $823 B-31 X-4$ & 95 & 102 & 291.5 & 2.92 & 3.5 & $F$ & VF & mud & mm...SS & $T$ & \\
\hline $823 B-31 X-5$ & 16 & 20 & 292.2 & 2.93 & 0.4 & VF & mud & & мm…SS & $T$ & \\
\hline $823 B-31 X-5$ & 20 & 21 & 292.2 & 2.93 & 0.4 & VF/silt & mud & & mm...SS & $T$ & \\
\hline $823 B-31 X-5$ & 53 & 58 & 292.6 & 2.93 & 0.2 & VF & mud & & 쓰…SS & $T$ & \\
\hline $823 B-31 X-5$ & 99 & 108 & 293.1 & 2.94 & 8.4 & $\mathrm{~F}$ & VF & mud & мm...SS & $\mathrm{T}$ & \\
\hline $823 B-31 X-5$ & 116 & 117 & 293.2 & 2.94 & 0.6 & F & mud & & л…SS & $T$ & \\
\hline $823 B-31 X-5$ & 139 & 140 & 293.4 & 2.94 & 0.4 & $\mathrm{~F}$ & mud & & mn…SS & $\mathrm{T}$ & \\
\hline $823 B-31 X-6$ & 34 & 39 & 293.9 & 2.95 & 0.2 & VF & mud & & mm...SS & $\mathrm{T}$ & \\
\hline $823 \mathrm{~B}-31 \mathrm{X}-6$ & 80 & 85 & 294.4 & 2.96 & 0.2 & VF/silt & mud & & mn…SS & $\mathrm{T}$ & ? \\
\hline $823 B-31 X-6$ & 107 & 135 & 294.9 & 2.96 & 28 & $\mathrm{M} / \mathrm{F}$ & VF/silt & & $m m=S S$ & $T$ & \\
\hline $823 B-31 X-6$ & 135 & 137 & 294.9 & 2.96 & 2 & $\mathrm{C}$ & & & $m$ & $T$ & \\
\hline $823 B-31 X-7$ & 16 & 23 & 295.2 & 2.97 & 7.6 & $\mathrm{~F}$ & VF & & мм… & $\mathrm{T}$ & \\
\hline $823 \mathrm{~B}-31 \mathrm{X}-7$ & 31 & 62 & 295.3 & 2.97 & 31 & $\mathrm{C}$ & M & & мп…… & $T$ & \\
\hline 823B-31X-7 & 62 & 78 & 295.3 & 2.97 & 15.3 & M & VF & & & $\mathrm{T}$ & \\
\hline $823 B-31 X-7$ & 91 & 111 & 295.3 & 2.97 & 20 & M & VF & & $m m \cdots=$ & $\mathrm{T}$ & \\
\hline $823 B-31 X-0$ & 0 & 21 & 295.5 & 2.97 & 20.3 & M & VF & & мm $\cdots=$ & $\mathrm{T}$ & \\
\hline $823 B-32 X-1$ & 38 & 40 & 296 & 2.98 & 1.8 & F & VF & & smm $\cdots$ & $T$ & \\
\hline 823B-32X-1 & 45 & 54 & 296.1 & 2.98 & 7.2 & $\mathrm{~F} / \mathrm{M}$ & silt & mud & $m m \cdots=S S$ & $T$ & \\
\hline $823 \mathrm{~B}-32 \mathrm{X}-1$ & 54 & 56 & 296.2 & 2.98 & 0.8 & VF & mud & & мm… & $T$ & \\
\hline $823 \mathrm{~B}-32 \mathrm{X}-1$ & 56 & 58 & 296.2 & 2.98 & 0.7 & $\mathrm{~F}$ & mud & & $m m \cdots$ & $\mathrm{T}$ & \\
\hline $823 \mathrm{~B}-32 \mathrm{X}-1$ & 58 & 69 & 296.3 & 2.98 & 8.4 & M & silt & mud & $m m \cdots=S S$ & $\mathrm{~T}$ & \\
\hline $823 \mathrm{~B}-32 \mathrm{X}-1$ & 84 & 97 & 296.6 & 2.99 & 9.3 & M & silt & mud & $m m \cdots=S 5$ & $\mathrm{~T}$ & \\
\hline 823B-32X-1 & 122 & 139 & 297 & 2.99 & 17 & M & silt & mud & $m m \cdots=S S$ & $\mathrm{~T}$ & \\
\hline 823B-32X-1 & 142 & 150 & 297.1 & 2.99 & 6.7 & VF & silt & mud & …SS & $\mathrm{T}$ & \\
\hline
\end{tabular}


Appendix A (continued).

\begin{tabular}{|c|c|c|c|c|}
\hline $823 B-32 X-2$ & 0 & 1 & 297.1 & 2.99 \\
\hline $823 B-32 X-2$ & 3 & 11 & 297.2 & 3 \\
\hline $823 B-32 X-2$ & 20 & 24 & 297.3 & 3 \\
\hline $823 B-32 X-2$ & 0 & 46 & 297.6 & 3 \\
\hline $823 B-32 X-2$ & 51 & 58 & 297.7 & 3 \\
\hline $823 B-32 X-2$ & 86 & 87 & 298 & 3 \\
\hline $823 B-32 X-2$ & 118 & 135 & 298.5 & 3.01 \\
\hline $823 B-32 X-3$ & 0 & 5 & 298.7 & 3.01 \\
\hline $823 B-32 X-3$ & 26 & 40 & 299 & 3.01 \\
\hline $823 B-32 X-3$ & 50 & 55 & 299.2 & 3.01 \\
\hline $823 B-32 X-3$ & 67 & 77 & 299.4 & 3.02 \\
\hline $823 B-32 X-3$ & 102 & 104 & 299.6 & 3.02 \\
\hline $823 B-32 X-4$ & 66 & 71 & 300.8 & 3.03 \\
\hline $823 B-32 X-4$ & 82 & 83 & 300.9 & 3.03 \\
\hline $823 \mathrm{~B}-32 \mathrm{X}-4$ & 95 & 103 & 301.1 & 3.03 \\
\hline $823 B-32 X-4$ & 126 & 128 & 301.4 & 3.03 \\
\hline $823 \mathrm{~B}-32 \mathrm{X}-4$ & 138 & 139 & 301.5 & 3.03 \\
\hline $823 B-32 X-4$ & 143 & 147 & 301.6 & 3.03 \\
\hline $823 B-32 X-5$ & 0 & 24 & 301.8 & 3.04 \\
\hline $823 B-32 X-5$ & 34 & 37 & 302 & 3.04 \\
\hline $823 B-32 X-5$ & 53 & 58 & 302.2 & 3.04 \\
\hline $823 B-32 X-5$ & 64 & 68 & 302.3 & 3.04 \\
\hline $823 B-32 X-5$ & 0 & 68 & 302.3 & 3.04 \\
\hline $823 B-32 X-5$ & 112 & 114 & 302.7 & 3.04 \\
\hline $823 B-32 X-5$ & 117 & 120 & 302.8 & 3.04 \\
\hline $823 B-32 X-5$ & 129 & 130 & 302.9 & 3.05 \\
\hline $823 B-32 X-6$ & 2 & 5 & 303.2 & 3.05 \\
\hline $823 B-32 X-6$ & 11 & 17 & 303.3 & 3.05 \\
\hline $823 \mathrm{~B}-32 \mathrm{X}-6$ & 18 & 19 & 303.3 & 3.05 \\
\hline $823 B-32 X-6$ & 37 & 42 & 303.5 & 3.05 \\
\hline $823 B-32 X-6$ & 87 & 91 & 304 & 3.06 \\
\hline $823 \mathrm{~B}-32 \mathrm{X}-0$ & 2 & 6 & 304.1 & 3.06 \\
\hline $823 \mathrm{~B}-32 \mathrm{X}-0$ & 11 & 15 & 304.2 & 3.06 \\
\hline $823 \mathrm{~B}-33 \mathrm{X}-1$ & 35 & 38 & 305.7 & 3.07 \\
\hline $823 B-33 X-1$ & 42 & 59 & 305.9 & 3.07 \\
\hline $823 \mathrm{~B}-33 \mathrm{X}-1$ & 61 & 67 & 306 & 3.07 \\
\hline $823 B-33 X-1$ & 68 & 73 & 306 & 3.07 \\
\hline $823 B-33 X-1$ & 84 & 88 & 306.2 & 3.07 \\
\hline $823 B-33 X-3$ & 20 & 26 & 308.6 & 3.09 \\
\hline $823 B-33 X-3$ & 43 & 44 & 308.7 & 3.1 \\
\hline $823 B-33 X-3$ & 66 & 70 & 309 & 3.1 \\
\hline $823 B-33 X-3$ & 121 & 123 & 309.5 & 3.1 \\
\hline $823 B-33 X-4$ & 3 & 6 & 309.9 & 3.1 \\
\hline $823 B-33 X-4$ & 44 & 45 & 310.3 & 3.11 \\
\hline $823 B-33 X-4$ & 83 & 88 & 310.7 & 3.11 \\
\hline $823 B-33 X-4$ & 88 & 91 & 310.7 & 3.11 \\
\hline $823 B-33 X-4$ & 120 & 123 & 311 & 3.11 \\
\hline $823 B-33 X-4$ & 130 & 140 & 311.2 & 3.12 \\
\hline $823 B-33 X-5$ & 44 & 49 & 311.8 & 3.12 \\
\hline $823 B-33 X-6$ & 68 & 73 & 313.5 & 3.13 \\
\hline $823 \mathrm{~B}-33 \mathrm{X}-0$ & 0 & 3 & 313.6 & 3.14 \\
\hline $823 B-33 X-0$ & 10 & 17 & 313.8 & 3.14 \\
\hline $823 \mathrm{~B}-33 \mathrm{X}-0$ & 17 & 22 & 313.8 & 3.14 \\
\hline $823 B-33 X-0$ & 38 & 39 & 314 & 3.14 \\
\hline $823 B-33 X-0$ & 53 & 55 & 314.2 & 3.14 \\
\hline $823 B-34 X-1$ & 14 & 15 & 315.1 & 3.15 \\
\hline $823 B-34 X-1$ & 120 & 125 & 316.2 & 3.16 \\
\hline $823 B-34 X-1$ & 127 & 128 & 316.2 & 3.16 \\
\hline $823 B-34 X-2$ & 43 & 53 & 316.9 & 3.16 \\
\hline $823 B-34 X-2$ & 93 & 96 & 317.4 & 3.17 \\
\hline $823 B-34 X-3$ & 0 & 150 & 319.4 & 3.18 \\
\hline $823 B-34 X-4$ & 0 & 150 & 320.9 & 3.2 \\
\hline $823 B-34 X-5$ & 0 & 3 & 320.9 & 3.2 \\
\hline $823 B-34 X-5$ & 20 & 36 & 321.3 & 3.2 \\
\hline $823 B-34 X-6$ & 0 & 6 & 322.5 & 3.21 \\
\hline $823 B-34 X-6$ & 0 & 40 & 322.8 & 3.21 \\
\hline $823 B-34 X-6$ & 0 & 40 & 322.8 & 3.21 \\
\hline
\end{tabular}

\begin{tabular}{|c|c|c|c|c|c|c|}
\hline 1.3 & $\mathrm{~F}$ & & & sm… & $\mathrm{T}$ & \\
\hline 4.5 & $\mathrm{~F}$ & silt & mud & $m m \ldots S S$ & $\mathrm{~T}$ & \\
\hline 1.3 & VF & mud & & mu…SS & $\mathrm{T}$ & \\
\hline 5 & $\mathrm{M}$ & silt & mud & mm...SS & $\mathrm{T}$ & \\
\hline 5.4 & $\mathrm{M}$ & silt & mud & mon...SS & $T$ & \\
\hline 0.4 & VF & mud & & $m m \ldots S S$ & $\mathrm{~T}$ & \\
\hline 16.8 & $\mathrm{M}$ & VF/silt & & mи...SS & $\mathrm{T}$ & \\
\hline 4.2 & F & VF & & mи…SS & $\mathrm{T}$ & \\
\hline 13 & $\mathrm{M}$ & silt & & mи…SS & $\mathrm{T}$ & \\
\hline 4 & VF & silt & mud & \#SSS & $\mathrm{T}$ & \\
\hline 9 & M & VF & & $\operatorname{sm}=$ & $\mathrm{T}$ & \\
\hline 1 & $\mathrm{~F}$ & mud & & \#SS & $\mathrm{T}$ & \\
\hline 3.9 & $\mathrm{M}$ & VF/silt & mud & nм...SSS & $\mathrm{T}$ & \\
\hline 1 & VF & silt & mud & mm...SS & $\mathrm{T}$ & \\
\hline 6.5 & $\mathrm{M}$ & silt & mud & nмm...SS & $\mathrm{T}$ & \\
\hline 1.8 & VF & silt & mud & мm…SS & $\mathrm{T}$ & \\
\hline 0.8 & $\mathrm{~F} / \mathrm{M}$ & & & мm…SS & $\mathrm{T}$ & \\
\hline 3 & $\mathrm{~F} / \mathrm{M}$ & mud & & Nm…SS & $\mathrm{T}$ & \\
\hline 14.8 & mud & $\mathrm{F}$ & & SST... muOT & $\mathrm{T}$ in $\mathrm{S}$ & \\
\hline 2.5 & silt & VF & & $S 5 \bar{m}_{\mathrm{mO}} \mathrm{OT}$ & $\mathrm{T}$ in $\mathrm{S}$ & \\
\hline 3.5 & silt & $\mathrm{F} / \mathrm{M}$ & & OTSS $\bar{\cdots}_{\mathrm{Nm}}$ & $\mathrm{T}$ in $\mathrm{S}$ & \\
\hline 3.7 & $F$ & $\mathrm{M} / \mathrm{C}$ & & … & $\mathrm{T}$ in $\mathrm{S}$ & \\
\hline 68 & & & & & $\mathrm{~S}$ & \\
\hline 2 & $\mathbf{F}$ & silt & & mm…SS & $\mathrm{T}$ & \\
\hline 1.5 & M & $\mathrm{F}$ & & nmSS & $\mathrm{T}$ & \\
\hline 0.3 & F & M & & mnSS & $\mathrm{T}$ & \\
\hline 3 & $\mathrm{M}$ & mud & & $m m \ldots 5 S$ & $\mathrm{~T}$ & \\
\hline 1.8 & F & mud & & mn...SS & $\mathrm{T}$ & \\
\hline 0.3 & VF & mud & & mm...SS & $\mathrm{T}$ & \\
\hline 2.3 & $\mathrm{M}$ & mud & & mm...SS & $\mathrm{T}$ & \\
\hline 0.4 & VF & mud & & $m n \ldots S S$ & $\mathrm{~T}$ & \\
\hline 0.9 & VF & mud & & mm...SS & $\mathrm{T}$ & \\
\hline 1 & $\mathrm{~F} / \mathrm{M}$ & silt & mud & $m m \ldots S S$ & $\mathrm{~T}$ & \\
\hline 1 & $\mathrm{~F}$ & silt & mud & $m n \ldots$...SS & $\mathrm{T}$ & \\
\hline 9.9 & $\mathrm{M} / \mathrm{C}$ & $\mathrm{F}$ & mud & nn…SS & $T$ & \\
\hline 0.1 & VF & mud & & mn…SS & $\mathrm{T}$ & \\
\hline 0.3 & VF & mud & & nm....SS & $\mathrm{T}$ & \\
\hline 0.1 & VF & mud & & min...SS & $\mathrm{T}$ & \\
\hline 3.7 & $\mathrm{C} / \mathrm{M}$ & mud & & mm…SS & $\mathrm{T}$ & \\
\hline 3.3 & $\mathrm{C}$ & $\mathrm{M} / \mathrm{F}$ & & IN m $\ldots$ SS & $\mathrm{T}$ in $\mathrm{S}$ & $?$ \\
\hline 1 & VF & mud & & mn…SS & $\mathrm{T}$ & \\
\hline 0.5 & $\mathrm{VF} / \mathrm{F}$ & mud & & mu…SS & $\mathrm{T}$ & \\
\hline 0.3 & VF & mud & & mm...sS & $\mathrm{T}$ & \\
\hline 0.3 & $\mathrm{VF} / \mathrm{F}$ & mud & & $m m \ldots S S$ & $\mathrm{~T}$ & \\
\hline 2.6 & VF & silt & & mm…SS & $\mathrm{T}$ & \\
\hline 2 & VF & silt & & mm...SS & $\mathrm{T}$ & \\
\hline 0.5 & VF & mud & & mm...SS & $T$ & \\
\hline 8.7 & VF & & & $\ddot{*}=$ SS & $\mathrm{T}$ & \\
\hline 1.1 & $\mathrm{~F} / \mathrm{VF}$ & silt & mud & mm… & $\mathrm{T}$ & \\
\hline 2.3 & F & M & mud & …ss & $T$ & \\
\hline 3 & $\mathrm{~F} / \mathrm{M}$ & & & mSS & $\mathrm{T}$ & \\
\hline 5.1 & $\mathrm{C} / \mathrm{M}$ & $\mathrm{M} / \mathrm{F}$ & & $\operatorname{sn} \cdots$ & $\mathrm{T}$ & \\
\hline 1.5 & $\mathrm{~F}$ & mud & & mm…SS & $\mathrm{T}$ & \\
\hline 1 & VF & VF & & $\equiv$ & $\mathrm{T}(2)$ & ? \\
\hline 0.6 & VF & silt & mud & Nm…SS & $\mathrm{T}$ & \\
\hline 1.1 & VF & mud & & ...SS & $\mathrm{T}$ & \\
\hline 1.1 & $\mathrm{~F}$ & silt & mud & mn…SS & $\mathrm{T}$ & \\
\hline 0.4 & $\mathrm{~F} / \mathrm{M}$ & silt & mud & mn...SS & $\mathrm{T}$ & \\
\hline 3.3 & VF & silt & mud & mu…SS & $\mathbf{T}$ & \\
\hline 2.5 & VF & mud & & mu…SSS & $\mathrm{T}$ & \\
\hline 150 & & & & & $D F$ to $S / 2$ & $?$ \\
\hline 150 & & & & $\Omega$ & $\mathrm{S} / 2$ & \\
\hline 3.3 & $\mathrm{~F}$ & silt & & мn… & $\mathrm{T}$ in $\mathrm{S}$ & $?$ \\
\hline 5.3 & $\mathrm{~F} / \mathrm{M}$ & VF & & mm… & $\mathrm{T}$ in $\mathrm{S}$ & \\
\hline 3.4 & mud & silt & F & OTSS\% $=\mathrm{mm}$ & $\mathrm{T}$ in $\mathrm{S}$ & \\
\hline 40 & & & & $\mathrm{IN} \Omega$ OT & $\mathrm{S} / 2$ & \\
\hline 490 & & & & $\mathbb{I N} \Omega$ OT & $\mathrm{S}$ & ? \\
\hline
\end{tabular}


Appendix A (continued).

\begin{tabular}{|c|c|c|c|c|c|c|c|c|c|c|c|}
\hline Sample & Top $(\mathrm{cm})$ & $\begin{array}{c}\text { Bottom } \\
(\mathrm{cm})\end{array}$ & Depth (m) & $\begin{array}{c}\text { Age } \\
\text { (ma) }\end{array}$ & Thickness (cm) & Texture Base & Texture Top & Mud cap & $\begin{array}{c}\text { Sedimentary } \\
\text { Structure }\end{array}$ & $\begin{array}{l}\text { Depositional } \\
\text { Mechanism }\end{array}$ & $?$ \\
\hline $823 \mathrm{~B}-35 \mathrm{X}-1$ & 2 & 7 & 324.7 & 3.23 & 0.7 & mud & silt/VF & mud & $S S_{\mathrm{mm}} \ldots \mathrm{ES}$ & $\mathrm{T}$ & \\
\hline $823 \mathrm{~B}-35 \mathrm{X}-1$ & 13 & 69 & 325.3 & 3.23 & 8 & M & mud & & SS & $\mathrm{T}$ & \\
\hline $823 \mathrm{~B}-35 \mathrm{X}-1$ & 69 & 75 & 325.4 & 3.23 & 7 & mud & & & mmSS & $\mathrm{T}$ & \\
\hline 823B-35X-1 & 100 & 108 & 325.7 & 3.23 & 5.5 & $\mathrm{VF} / \mathrm{F}$ & silt & mud & 그…SS & $\mathrm{T}$ & \\
\hline $823 \mathrm{~B}-35 \mathrm{X}-1$ & 126 & 133 & 325.9 & 3.24 & 5.5 & VF & silt & mud & $\operatorname{sn} \cdots=5 S$ & $\mathrm{~T}$ & \\
\hline $823 \mathrm{~B}-35 \mathrm{X}-1$ & 136 & 142 & 326 & 3.24 & 3.7 & VF & silt & mud & 쓰노S & $\mathrm{T}$ & \\
\hline $823 \mathrm{~B}-35 \mathrm{X}-2$ & 4 & 9 & 326.2 & 3.24 & 1.4 & VF & silt & mud & sm…SS & $\mathrm{T}$ & \\
\hline $823 \mathrm{~B}-35 \mathrm{X}-2$ & 20 & 46 & 326.6 & 3.24 & 17 & $\mathrm{~F} / \mathrm{M}$ & silt & mud & sm $\cdots=S S$ & $\mathrm{~T}$ & \\
\hline $823 \mathrm{~B}-35 \mathrm{X}-2$ & 58 & 62 & 326.7 & 3.24 & 2.6 & silt & mud & & ми…SS & $T$ & \\
\hline $823 \mathrm{~B}-35 \mathrm{X}-2$ & 75 & 80 & 326.9 & 3.24 & 3.9 & $\mathrm{~F}$ & silt & & мm… & $\mathrm{T}$ & \\
\hline $823 \mathrm{~B}-35 \mathrm{X}-2$ & 92 & 95 & 327.1 & 3.25 & 0.8 & VF & mud & & 쓰…SS & $\mathrm{T}$ & \\
\hline $823 \mathrm{~B}-35 \mathrm{X}-2$ & 101 & 106 & 327.2 & 3.25 & 0.8 & VF & mud & & mm...SS & T & \\
\hline $823 \mathrm{~B}-35 \mathrm{X}-2$ & 115 & 128 & 327.4 & 3.25 & 13.3 & $\mathrm{~F}$ & mud & & & $\mathrm{T}$ & \\
\hline $823 \mathrm{~B}-35 \mathrm{X}-2$ & 134 & 136 & 327.5 & 3.25 & 1.6 & $\mathrm{~F}$ & silt & mud & mm...SS & $\mathrm{T}$ & \\
\hline $823 \mathrm{~B}-35 \mathrm{X}-3$ & 68 & 74 & 328.3 & 3.26 & 4 & mud & VF & & SS… OT & $\mathrm{T}$ in $\mathrm{S}$ & ? \\
\hline $823 \mathrm{~B}-35 \mathrm{X}-3$ & 45 & 74 & 328.3 & 3.26 & 29 & mud & VF & & SS…OT & $\mathrm{S}$ & $?$ \\
\hline $823 \mathrm{~B}-35 \mathrm{X}-3$ & 113 & 120 & 328.8 & 3.26 & 7 & VF & mud & & мm… & $\mathrm{T}$ & \\
\hline $823 \mathrm{~B}-35 \mathrm{X}-4$ & 22 & 24 & 329.3 & 3.26 & 1.5 & VF & mud & & мm...SS & T & \\
\hline $823 \mathrm{~B}-35 \mathrm{X}-4$ & 24 & 25 & 329.4 & 3.26 & 1 & VF & mud & & mm…SS & $\mathrm{T}$ & \\
\hline $823 \mathrm{~B}-35 \mathrm{X}-4$ & 47 & 49 & 329.6 & 3.27 & 0.8 & VF & mud & & ми…SS & $\mathrm{T}$ & \\
\hline $823 \mathrm{~B}-35 \mathrm{X}-4$ & 63 & 65 & 329.8 & 3.27 & 0.6 & VF & mud & & mu…SS & $\mathrm{T}$ & \\
\hline $823 \mathrm{~B}-35 \mathrm{X}-4$ & 111 & 114 & 330.2 & 3.27 & 1 & VF & mud & & $\operatorname{sm}=\mathbb{I N}$ & $\mathrm{T}$ in $\mathrm{S}$ & ? \\
\hline $823 \mathrm{~B}-35 \mathrm{X}-5$ & 30 & 31 & 330.9 & 3.28 & 1 & VF & mud & & $\operatorname{mn} \cdots$ & $T$ & ? \\
\hline $823 \mathrm{~B}-36 \mathrm{X}-1$ & 19 & 21 & 334.4 & 3.31 & 1.1 & $\mathrm{M} / \mathrm{C}$ & & & & $\mathrm{T}$ in $\mathrm{S}$ & $?$ \\
\hline $823 \mathrm{~B}-36 \mathrm{X}-1$ & 127 & 131 & 335.5 & 3.31 & 1.3 & $\mathrm{M} / \mathrm{F}$ & & & m $\cdots$ IN OT & $\mathrm{T}$ in $\mathrm{S}$ & $?$ \\
\hline $823 \mathrm{~B}-36 \mathrm{X}-1$ & 141 & 148 & 335.7 & 3.32 & 1.7 & M & $\mathrm{F}$ & & sm $\cdots$ IN OT & $\mathrm{T}$ in $\mathrm{S}$ & ? \\
\hline $823 \mathrm{~B}-36 \mathrm{X}-1$ & 0 & 150 & 335.7 & 3.32 & 150 & & & & $\mathbb{I N} \equiv O T$ & $\mathrm{~S} / 2$ & $?$ \\
\hline $823 \mathrm{~B}-36 \mathrm{X}-2$ & 78 & 79 & 336.5 & 3.32 & 1.5 & $\mathrm{C} / \mathrm{M}$ & F & & $\bar{\cdots}$ & $\mathrm{T}$ in $\mathrm{S}$ & $?$ \\
\hline $823 B-36 X-2$ & 80 & 88 & 336.6 & 3.32 & 6.7 & $\mathrm{M} / \mathrm{F}$ & & & $\operatorname{sn} \cdots$ & $\mathrm{T}$ in $\mathrm{S}$ & \\
\hline $823 \mathrm{~B}-36 \mathrm{X}-2$ & 0 & 150 & 337.2 & 3.33 & 150 & & & & $I N \equiv S S_{\text {m }}$ OT & $\mathrm{S} / 2$ & ? \\
\hline $823 B-36 X-6$ & 90 & 93 & 342.6 & 3.37 & 4 & M & mud & & nn…SS & $\mathrm{T}$ & ? \\
\hline $823 \mathrm{~B}-37 \mathrm{X}-2$ & 69 & 73 & 346.1 & 3.4 & 2.9 & M & mud & & mm & $\mathrm{T}$ & ? \\
\hline $823 \mathrm{~B}-37 \mathrm{X}-2$ & 105 & 106 & 346.5 & 3.4 & 0.8 & VF & $\mathrm{F}$ & & muss & $\mathrm{T}$ & ? \\
\hline $823 \mathrm{~B}-37 \mathrm{X}-4$ & 21 & 22 & 348.6 & 3.42 & 0.2 & F & VF & & & $\mathrm{T}$ & $?$ \\
\hline 823B-37X-7 & 0 & 58 & 353.5 & 3.46 & 58 & mud & $4.7 \mathrm{~cm}$ & & CSBU $\Omega S S$ & $\mathrm{DF} / 2$ & \\
\hline 823B-37X-0 & 0 & 44 & 353.9 & 3.47 & 44 & mud & $4 \mathrm{~cm}$ & & 几CSms & $\mathrm{DF} / 2$ & \\
\hline $823 \mathrm{~B}-37 \mathrm{X}-0$ & 0 & 44 & 353.9 & 3.47 & 131 & & & & 几csms & DF & \\
\hline $823 \mathrm{~B}-38 \mathrm{X}-1$ & 0 & 83 & 354.2 & 3.47 & 83 & & & & $\mathbb{I N} \equiv S S \Omega$ & $\mathrm{S} / 2$ & \\
\hline $823 \mathrm{~B}-38 \mathrm{X}-2$ & 48 & 150 & 355.3 & 3.49 & 102 & mud & $6 \mathrm{~cm}$ & & ms & $\mathrm{DF} / 2$ & \\
\hline $823 \mathrm{~B}-38 \mathrm{X}-3$ & 0 & 150 & 356.8 & 3.5 & 150 & mud & $2 \mathrm{~cm}$ & & $\mathbb{I N} \equiv \Omega$ & $\mathrm{DF}$ to $\mathrm{S} / 2$ & \\
\hline $823 \mathrm{~B}-38 \mathrm{X}-4$ & 0 & 150 & 358.3 & 3.51 & 150 & mud & $10 \mathrm{~cm}$ & & $\mathbb{I N} \equiv \Omega \operatorname{CS} M S B U$ & $\mathrm{DF}$ to $\mathrm{S} / 2$ & \\
\hline 823B-38X-6 & 0 & 150 & 361.3 & 3.52 & 150 & mud & $3.3 \mathrm{~cm}$ & & $\mathbb{I N} \equiv C S M S B U \Omega S S$ & $\mathrm{DF} / 2$ & \\
\hline $823 \mathrm{~B}-38 \mathrm{X}-7$ & 0 & 135 & 362.7 & 3.53 & 135 & mud & $4.6 \mathrm{~cm}$ & & $\mathrm{IN} \equiv \mathrm{CS} B \mathrm{~V}$ & $\mathrm{DF}$ to $\mathrm{S} / 2$ & \\
\hline $823 \mathrm{~B}-38 \mathrm{X}-0$ & 0 & 32 & 363 & 3.53 & 32 & mud & $5.5 \mathrm{~cm}$ & & $\mathrm{IN} \equiv \mathrm{CS}$ & $\mathrm{DF} / 2$ & \\
\hline $823 \mathrm{~B}-38 \mathrm{X}-0$ & 0 & 32 & 363 & 3.52 & 869 & & & & & DF & \\
\hline $823 \mathrm{~B}-39 \mathrm{X}-1$ & 28 & 150 & 364.5 & 3.54 & 122 & & & & $I N \equiv S S \Omega$ & $\mathrm{S} / 2$ & \\
\hline $823 \mathrm{~B}-39 \mathrm{X}-2$ & 0 & 150 & 366 & 3.54 & 150 & & & & $I N \equiv S S$ & $\mathrm{~s} / 2$ & \\
\hline $823 \mathrm{~B}-39 \mathrm{X}-3$ & 31 & 33 & 366.3 & 3.54 & 1 & M & & & & $\mathrm{T}$ in $\mathrm{S}$ & \\
\hline $823 \mathrm{~B}-39 \mathrm{X}-3$ & 137 & 150 & 367.5 & 3.55 & 1.4 & M & & & $I_{\mathrm{N}} \ldots \mathrm{KS}$ OT & $\mathrm{T}$ in $\mathrm{S}$ & \\
\hline $823 \mathrm{~B}-39 \mathrm{X}-3$ & 0 & 150 & 367.5 & 3.55 & 150 & & & & $I N \equiv \Omega S S$ & $\mathrm{~S} / 2$ & \\
\hline $823 B-39 X-4$ & 135 & 142 & 368.9 & 3.56 & 0.9 & M & $\mathrm{F}$ & & $\Omega$ & $\mathrm{T}$ in $\mathrm{S}$ & \\
\hline $823 B-39 X-4$ & 0 & 150 & 369 & 3.56 & 150 & & & & $\mathbb{I N} \equiv \Omega$ & $\mathrm{S} / 2$ & \\
\hline $823 \mathrm{~B}-39 \mathrm{X}-4$ & 0 & 150 & 369 & 3.56 & 572 & & & & $\mathbb{I N} \equiv \Omega$ & $\mathrm{s}$ & \\
\hline $823 B-39 X-5$ & 0 & 6 & 369.1 & 3.56 & 6 & & & & CSBV & DF & \\
\hline $823 B-39 X-6$ & 52 & 150 & 372 & 3.57 & 98 & mud & $7 \mathrm{~cm}$ & & CS $\Omega \mathrm{ms}$ & $\mathrm{DF} / 2$ & \\
\hline 823B-39X-7 & 0 & 27 & 372.3 & 3.57 & 27 & mud & $2 \mathrm{~cm}$ & & $\mathbb{I N} \equiv \Omega \operatorname{CSB}$ & $\mathrm{S}$ to $\mathrm{DF} / 2$ & \\
\hline $823 \mathrm{~B}-39 \mathrm{X}-0$ & 0 & 24 & 372.5 & 3.57 & 24 & mud & $1.4 \mathrm{~cm}$ & & $\mathbb{I N} \equiv \Omega \mathrm{MS}$ & $\mathrm{S}$ to $\mathrm{DF} / 2$ & \\
\hline $823 \mathrm{~B}-40 \mathrm{X}-1$ & 0 & 150 & 374.2 & 3.58 & 150 & & & & $\Omega \mathbb{I N} \equiv \mathrm{BUCS}$ & $\mathrm{DF}$ to $\mathrm{S} / 2$ & \\
\hline $823 \mathrm{~B}-40 \mathrm{X}-2$ & 0 & 150 & 375.7 & 3.59 & 150 & mud & $4 \mathrm{~cm}$ & & $\equiv \mathbb{I N} \Omega B \cup C S$ & $D F$ to $S / 2$ & \\
\hline $823 \mathrm{~B}-40 \mathrm{X}-4$ & 0 & 14 & 377.3 & 3.6 & 14 & & & & $\equiv \Omega=$ & $\mathrm{S}$ or DF/2 & \\
\hline $823 \mathrm{~B}-40 \mathrm{X}-4$ & 14 & 150 & 378.7 & 3.6 & 136 & mud & $1.4 \mathrm{~cm}$ & & ms & $\mathrm{DF} / 2$ & \\
\hline $823 B-40 X-5$ & 0 & 150 & 380.2 & 3.61 & 150 & mud & $5.5 \mathrm{~cm}$ & & msCS 几CS & $\mathrm{DF} / 2$ & \\
\hline $823 \mathrm{~B}-40 \mathrm{X}-6$ & 0 & 150 & 381.7 & 3.62 & 150 & mud & $5 \mathrm{~cm}$ & & MSBU 几CS & $\mathrm{DF} / 2$ & \\
\hline $823 \mathrm{~B}-40 \mathrm{X}-7$ & 0 & 50 & 382.2 & 3.62 & 50 & mud & $3 \mathrm{~cm}$ & & mSBU 几CS & $\mathrm{DF} / 2$ & \\
\hline $823 \mathrm{~B}-40 \mathrm{X}-0$ & 0 & 36 & 382.6 & 3.62 & 36 & mud & $2 \mathrm{~cm}$ & & mSBU 几CS & DF to $S$ & \\
\hline
\end{tabular}


Appendix A (continued).

\begin{tabular}{|c|c|c|c|c|c|c|c|c|c|c|}
\hline Sample & Top $(\mathrm{cm})$ & $\begin{array}{c}\text { Bottom } \\
(\mathrm{cm})\end{array}$ & Depth (m) & $\begin{array}{l}\text { Age } \\
\text { (ma) } 1\end{array}$ & Thickness (cm) & Texture Base & Texture Top Mud cap & $\begin{array}{l}\text { Sedimentary } \\
\text { Structure }\end{array}$ & $\begin{array}{l}\text { Depositional } \\
\text { Mechanism }\end{array}$ & ? \\
\hline $823 \mathrm{~B}-41 \mathrm{X}-1$ & 0 & 150 & 383.9 & 3.63 & 150 & & & $\mathbb{I N} \equiv \Omega$ & $\mathrm{S}$ & \\
\hline $823 \mathrm{~B}-41 \mathrm{X}-2$ & 93 & 114 & 385 & 3.63 & 61 & & & IN & S & ? \\
\hline $823 \mathrm{~B}-41 \mathrm{X}-3$ & 122 & 150 & 386.9 & 3.64 & 28 & & & $I N \equiv S S$ & S & \\
\hline $823 B-41 X-4$ & 17 & 23 & 387.1 & 3.65 & 4 & $\mathrm{M} / \mathrm{C}$ & $\mathrm{F}$ & mm...SS & $\mathrm{T}$ & \\
\hline $823 \mathrm{~B}-41 \mathrm{X}-4$ & 130 & 150 & 388.4 & 3.65 & 13 & $\mathrm{M} / \mathrm{C}$ & $\mathrm{M} / \mathrm{F}$ & $\stackrel{\cdots}{*} \mathbb{N}$ & $T$ in $S$ & \\
\hline $823 B-41 X-4$ & 37 & 150 & 388.4 & 3.65 & 113 & & & $\mathbb{I N} \equiv S S$ & $\mathrm{~S} / 2$ & \\
\hline $823 \mathrm{~B}-41 \mathrm{X}-5$ & 0 & 150 & 389 & 3.65 & 150 & & & $I N \equiv S S$ & $\mathrm{~S} / 2$ & \\
\hline $823 \mathrm{~B}-41 \mathrm{X}-6$ & 0 & 54 & 390.4 & 3.66 & 54 & & & $\mathbb{I N} \equiv S S$ & $\mathrm{~S} / 2$ & \\
\hline $823 \mathrm{~B}-41 \mathrm{X}-6$ & 0 & 54 & 390.4 & 3.66 & 317 & & & $\mathbb{I N} \equiv S S$ & $\mathrm{~s}$ & \\
\hline $823 \mathrm{~B}-41 \mathrm{X}-6$ & 87 & 121 & 391.1 & 3.66 & 34 & & & $\mathbb{I N} \equiv S S$ & $\mathrm{~S}$ & \\
\hline $823 \mathrm{~B}-41 \mathrm{X}-6$ & 121 & 150 & 391.4 & 3.67 & 29 & & & mSBU $\Omega$ & $\mathrm{DF} / 2$ & \\
\hline $823 \mathrm{~B}-41 \mathrm{X}-7$ & 0 & 40 & 391.8 & 3.67 & 40 & mud & $2.5 \mathrm{~cm}$ & CSMSBU $\Omega$ & $\mathrm{DF} / 2$ & \\
\hline $823 \mathrm{~B}-41 \mathrm{X}-7$ & 0 & 40 & 391.8 & 3.67 & 69 & & & 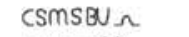 & DF & \\
\hline $823 \mathrm{~B}-42 \mathrm{X}-1$ & 19 & 150 & 393.5 & 3.68 & 131 & & & $\mathbb{I N} \equiv S S \Omega$ & $\mathrm{S} / 2$ & \\
\hline $823 \mathrm{~B}-42 \mathrm{X}-2$ & 0 & 150 & 395 & 3.68 & 150 & & & $\mathbb{I N} \equiv S S \Omega$ & $\mathrm{S} / 2$ & \\
\hline $823 B-42 X-3$ & 0 & 81 & 395.8 & 3.69 & 81 & & & $\Omega$ & $\mathrm{s} / 2$ & \\
\hline $823 \mathrm{~B}-42 \mathrm{X}-3$ & 0 & 81 & 395.8 & 3.69 & 362 & & & $\Omega$ & $\mathrm{s}$ & \\
\hline $823 \mathrm{~B}-42 \mathrm{X}-3$ & 81 & 150 & 396.5 & 3.69 & 69 & mud & $3 \mathrm{~cm}$ & cs_ms & DF & \\
\hline $823 \mathrm{~B}-42 \mathrm{X}-4$ & 0 & 117 & 397.7 & 3.7 & 117 & & & $\Omega \mathbb{N} \equiv S S$ & $\mathrm{~s}$ & \\
\hline $823 \mathrm{~B}-42 \mathrm{X}-5$ & 0 & 38 & 398.4 & 3.7 & 38 & & & $\operatorname{CSBN} \Omega$ & DF & \\
\hline $823 \mathrm{~B}-42 \mathrm{X}-5$ & 38 & 71 & 398.7 & 3.7 & 31 & mud & $3 \mathrm{~cm}$ & $\Omega \mathbb{I N B V}$ & $S$ to $D F$ & \\
\hline $823 \mathrm{~B}-42 \mathrm{X}-5$ & 123 & 150 & 399.5 & 3.71 & 27 & & & $\mathbb{I N} \equiv$ & $\mathrm{S}$ & $?$ \\
\hline $823 \mathrm{~B}-42 \mathrm{X}-7$ & 0 & 0 & 401 & 3.71 & 2 & VF & $\mathrm{F}$ & & $\mathrm{T}$ & \\
\hline $823 \mathrm{~B}-42 \mathrm{X}-0$ & 22 & 37 & 401.8 & 3.72 & 2.6 & & & $I N \Omega M S S S$ & $\mathrm{~T}$ in $\mathrm{S}$ & \\
\hline $823 \mathrm{~B}-43 \mathrm{X}-3$ & 15 & 19 & 404.8 & 3.73 & 4 & $\mathrm{C} / \mathrm{M}$ & $\mathrm{F}$ & & $T$ & ? \\
\hline $823 \mathrm{~B}-43 \mathrm{X}-3$ & 124 & 150 & 406.1 & 3.74 & 26 & & & $\Omega \mathbb{N}$ & $\mathrm{S}$ & \\
\hline $823 \mathrm{~B}-43 \mathrm{X}-4$ & 0 & 150 & 407.6 & 3.74 & 150 & mud & $6 \mathrm{~cm}$ & $C S \cap B U \equiv$ & $D F$ to $S / 2$ & \\
\hline $823 B-43 X-5$ & 0 & 41 & 408 & 3.75 & 41 & & & CSתSSS & $\mathrm{DF} / 2$ & \\
\hline $823 \mathrm{~B}-43 \mathrm{X}-5$ & 0 & 41 & 408 & 3.75 & 191 & & & CSASS & $\mathrm{DF}$ & \\
\hline $823 \mathrm{~B}-43 \mathrm{X}-5$ & 107 & 114 & 408.7 & 3.75 & 5 & $\mathrm{C} / \mathrm{M}$ & VF & IN & $\mathrm{T}$ in $\mathrm{S}$ & \\
\hline $823 \mathrm{~B}-43 \mathrm{X}-5$ & 41 & 114 & 408.7 & 3.75 & 73 & & & IN SS & $\mathrm{s}$ & ? \\
\hline $823 \mathrm{~B}-43 \mathrm{X}-6$ & 55 & 150 & 410.6 & 3.76 & 95 & & & IN SS & $\mathrm{S} / 2$ & \\
\hline $823 \mathrm{~B}-43 \mathrm{X}-7$ & 0 & 56 & 411.2 & 3.76 & 151 & & & IN SS & $\mathrm{S}$ & ? \\
\hline $823 \mathrm{~B}-44 \mathrm{X}-1$ & 20 & 100 & 412.3 & 3.77 & 80 & mud & $3.2 \mathrm{~cm}$ & $\operatorname{CSBU} \Omega$ & $\mathrm{DF}$ to $\mathrm{S} / 2$ & \\
\hline $823 \mathrm{~B}-44 \mathrm{X}-1$ & 0 & 100 & 412.3 & 3.77 & 100 & & & & $D F$ to $S$ & \\
\hline $823 \mathrm{~B}-44 \mathrm{X}-1$ & 100 & 150 & 412.8 & 3.77 & 50 & & & $\mathbb{I N} \equiv \Omega$ & $\mathrm{S} / 2$ & \\
\hline $823 \mathrm{~B}-44 \mathrm{X}-2$ & 0 & 85 & 413.7 & 3.77 & 85 & & & $I N \equiv S S$ & $\mathrm{~S} / 2$ & \\
\hline $823 \mathrm{~B}-44 \mathrm{X}-2$ & 0 & 85 & 413.7 & 3.77 & 135 & & & $I N \equiv S S$ & $\mathrm{~S}$ & \\
\hline $823 \mathrm{~B}-44 \mathrm{X}-2$ & 148 & 149 & 414.3 & 3.78 & 0.3 & M & F & & $\mathrm{T}$ & ? \\
\hline $823 \mathrm{~B}-44 \mathrm{X}-3$ & 0 & 40 & 414.7 & 3.78 & 40 & & & IN & $\mathrm{S} / 2$ & $?$ \\
\hline $823 \mathrm{~B}-44 \mathrm{X}-3$ & 40 & 85 & 415.2 & 3.78 & 45 & & & IN SS & $\mathrm{S} / 2$ & ? \\
\hline $823 \mathrm{~B}-44 \mathrm{X}-3$ & 40 & 85 & 415.2 & 3.78 & 85 & & & IN SS & $\mathrm{s}$ & $?$ \\
\hline $823 \mathrm{~B}-44 \mathrm{X}-3$ & 85 & 150 & 415.8 & 3.78 & 65 & & & msss & $\mathrm{DF} / 2$ & ? \\
\hline $823 B-44 X-5$ & 0 & 150 & 418.8 & 3.8 & 327 & & & CSBU $\Omega \mathrm{mS}$ & DF & \\
\hline $823 \mathrm{~B}-44 \mathrm{X}-6$ & 0 & 150 & 420.3 & 3.81 & 150 & & & $\equiv$ & $\mathrm{S} / 2$ & $?$ \\
\hline $823 \mathrm{~B}-44 \mathrm{X}-7$ & 0 & 39 & 420.7 & 3.81 & 39 & & & $\Omega \equiv$ & $\mathrm{S} / 2$ & \\
\hline $823 \mathrm{~B}-44 \mathrm{X}-0$ & 0 & 34 & 421.1 & 3.81 & 34 & & & $\Lambda \equiv$ & $\mathrm{S} / 2$ & \\
\hline $823 \mathrm{~B}-45 \mathrm{X}-1$ & 0 & 82 & 421.7 & 3.81 & 82 & & & $\mathrm{IN} \Omega \equiv C S B V$ & $\mathrm{~S}$ or DF $/ 2$ & \\
\hline $823 \mathrm{~B}-45 \mathrm{X}-1$ & 82 & 150 & 422.4 & 3.82 & 78 & & & SS IN & $\mathrm{S} / 2$ & $?$ \\
\hline $823 B-45 X-2$ & 19 & 23 & 422.6 & 3.82 & 1 & F & M & ми… & $\mathrm{T}$ in $\mathrm{S}$ & \\
\hline $823 \mathrm{~B}-45 \mathrm{X}-2$ & 0 & 32 & 422.7 & 3.82 & 32 & & & IN 200 SS & $\mathrm{S} / 2$ & ? \\
\hline $823 \mathrm{~B}-45 \mathrm{X}-2$ & 0 & 32 & 422.7 & 3.82 & 405 & & & Zoo SS IN & $S$ & \\
\hline $823 B-45 X-2$ & 50 & 51 & 422.9 & 3.82 & 1.5 & M & F & m…SS & $\mathrm{T}$ & \\
\hline $823 \mathrm{~B}-45 \mathrm{X}-2$ & 116 & 117 & 423.6 & 3.82 & 0.4 & F & & & $\mathrm{T}$ & \\
\hline $823 \mathrm{~B}-45 \mathrm{X}-2$ & 122 & 150 & 423.9 & 3.82 & 28 & & & $\Omega \mathrm{ms}$ & $D F$ to $S$ & \\
\hline $823 \mathrm{~B}-45 \mathrm{X}-4$ & 90 & 107 & 426.5 & 3.84 & 17 & & & BU & $D F$ in $S$ & \\
\hline $823 \mathrm{~B}-45 \mathrm{X}-4$ & 0 & 150 & 426.9 & 3.84 & 150 & & & IN SS & $\mathrm{S}$ & ? \\
\hline $823 \mathrm{~B}-45 \mathrm{X}-5$ & 66 & 73 & 427.6 & 3.84 & 5.5 & M & $\mathrm{F}$ & SS & $\mathrm{T}$ in $\mathrm{S}$ & ? \\
\hline $823 \mathrm{~B}-45 \mathrm{X}-5$ & 101 & 104 & 427.9 & 3.84 & 1 & F & M & m…SS & $\mathrm{T}$ in $\mathrm{S}$ & \\
\hline $823 \mathrm{~B}-45 \mathrm{X}-5$ & 48 & 115 & 428.1 & 3.84 & 67 & & & IN $5 S \mathrm{~mm}$ & $\mathrm{~S} / 2$ & \\
\hline $823 \mathrm{~B}-45 \mathrm{X}-6$ & 23 & 32 & 428.7 & 3.85 & 6 & M & F & IN m & $\mathrm{T}$ in $\mathrm{S}$ & \\
\hline $823 \mathrm{~B}-45 \mathrm{X}-6$ & 0 & 74 & 429.1 & 3.85 & 74 & & & IN & $\mathrm{s} / 2$ & $?$ \\
\hline $823 \mathrm{~B}-45 \mathrm{X}-6$ & 0 & 74 & 429.1 & 3.85 & 147 & & & IN & $\mathrm{s}$ & ? \\
\hline $823 \mathrm{~B}-45 \mathrm{X}-6$ & 128 & 137 & 429.8 & 3.85 & 4 & $\mathrm{M}$ & $\mathrm{F}$ & & $\mathrm{T}$ & ? \\
\hline $823 \mathrm{~B}-45 \mathrm{X}-7$ & 10 & 56 & 430.5 & 3.86 & 46 & mud & $5 \mathrm{~cm}$ & CS $\Omega$ MSBUSS & $\mathrm{DF} / 2$ & \\
\hline
\end{tabular}


Appendix A (continued).

\begin{tabular}{|c|c|c|c|c|c|c|c|c|c|c|c|}
\hline Sample & Top $(\mathrm{cm})$ & $\begin{array}{c}\text { Bottom } \\
(\mathrm{cm})\end{array}$ & Depth (m) & $\begin{array}{l}\text { Age } \\
\text { (ma) }\end{array}$ & Thickness $(\mathrm{cm})$ & Texture Base & Texture Top & Mud cap & $\begin{array}{l}\text { Sedimentary } \\
\text { Structure }\end{array}$ & $\begin{array}{l}\text { Depositional } \\
\text { Mechanism }\end{array}$ & $?$ \\
\hline $823 \mathrm{~B}-46 \mathrm{X}-3$ & 0 & 36 & 434 & 3.87 & 36 & mud & $2 \mathrm{~cm}$ & & 几mSSs & $\mathrm{DF}$ or $\mathrm{S} / 2$ & \\
\hline $823 \mathrm{~B}-46 \mathrm{X}-3$ & 0 & 36 & 434 & 3.87 & 430 & & & & 几msss & DF & \\
\hline $823 \mathrm{~B}-46 \mathrm{X}-3$ & 36 & 150 & 435.1 & 3.88 & 114 & & & & $几 \equiv S S$ & $\mathrm{~S}$ & \\
\hline $823 \mathrm{~B}-46 \mathrm{X}-4$ & 0 & 150 & 436.6 & 3.88 & 150 & mud & $4.5 \mathrm{~cm}$ & & & $\mathrm{DF} / 2$ & \\
\hline $823 \mathrm{~B}-46 \mathrm{X}-5$ & 0 & 150 & 438.1 & 3.88 & 150 & mud & $9 \mathrm{~cm}$ & & $\mathrm{~ms} \Omega \mathrm{CS}$ & $\mathrm{DF} / 2$ & \\
\hline $823 \mathrm{~B}-46 \mathrm{X}-6$ & 0 & 52 & 438.6 & 3.88 & 352 & & & & $\mathrm{~ms} \Omega \mathrm{CS}$ & $\mathrm{DF}$ & \\
\hline $823 B-46 X-6$ & 52 & 150 & 439.6 & 3.88 & 98 & & & & $\Omega \mathbb{I N} \mathbb{I} / \mathrm{l}$ & $\mathrm{s} / 2$ & \\
\hline $823 B-47 X-1$ & 129 & 134 & 441.6 & 3.88 & 3.5 & $\mathrm{~F}$ & $\mathrm{M}(\mathrm{C}-\mathrm{VC})$ & & IN $\cdots$ & $\mathrm{T}$ in $\mathrm{S}$ & \\
\hline $823 B-47 X-1$ & 24 & 150 & 441.8 & 3.88 & 126 & & & & $I N \Omega \equiv S S$ & $\mathrm{~S} / 2$ & \\
\hline $823 B-47 X-2$ & 110 & 127 & 443.1 & 3.88 & 2 & $\mathrm{~F}$ & M & & IN OT $\bar{m}$ & $\mathrm{~T}$ in $\mathrm{S}$ & \\
\hline $823 \mathrm{~B}-47 \mathrm{X}-2$ & 0 & 150 & 443.3 & 3.88 & 150 & & & & $\Omega$ IN SS & $\mathrm{S} / 2$ & \\
\hline $823 B-47 X-3$ & 53 & 69 & 444 & 3.88 & 1.8 & c & F & & ...SS & $\mathrm{T}$ in $\mathrm{S}$ & \\
\hline $823 B-47 X-3$ & 0 & 150 & 444.8 & 3.88 & 150 & & & & $\Omega I N S S$ & $\mathrm{~S} / 2$ & \\
\hline $823 B-47 X-3$ & 0 & 150 & 444.8 & 3.88 & 426 & & & & & $\mathrm{~s}$ & \\
\hline $823 B-47 X-4$ & 101 & 105 & 445.9 & 3.88 & 2.5 & M & C & & $\Omega$ & $\mathrm{T}$ & \\
\hline $823 B-47 X-4$ & 12 & 120 & 446 & 3.88 & 108 & & & & $\Omega S S I N$ & DF to $S$ & \\
\hline $823 B-47 X-5$ & 0 & 150 & 447.8 & 3.88 & 150 & & & & msss & DF & \\
\hline $823 B-47 X-6$ & 0 & 3 & 447.8 & 3.88 & 3 & C & M & & m & $\mathrm{T}$ in $\mathrm{S}$ & \\
\hline $823 B-47 X-6$ & 27 & 34 & 448.1 & 3.88 & 1.8 & $\mathrm{~F}$ & C & & IN OT $\bar{\cdots}$ & $T$ in $S$ & \\
\hline $823 \mathrm{~B}-47 \mathrm{X}-6$ & 50 & 52 & 448.3 & 3.88 & 1.6 & M & F & & IN OT $\cdots$ & $\mathrm{T}$ in $\mathrm{S}$ & \\
\hline $823 B-47 X-6$ & 0 & 52 & 448.3 & 3.88 & 52 & & & & $\Omega \mathbb{I N}$ & $\mathrm{S}$ & \\
\hline $823 \mathrm{~B}-48 \mathrm{X}-1$ & 0 & 80 & 450.7 & 3.89 & 80 & & & & $\Omega 700$ & DF in $S$ & \\
\hline $823 \mathrm{~B}-48 \mathrm{X}-1$ & 133 & 143 & 451.3 & 3.89 & 10.7 & mud & $4.5 \mathrm{~cm}$ & & $\mathrm{~ms}$ & $\mathrm{DF}$ in $\mathrm{S}$ & \\
\hline $823 \mathrm{~B}-48 \mathrm{X}-1$ & 0 & 143 & 451.3 & 3.89 & 143 & & & & $\mathrm{~ms}$ & DF & \\
\hline $823 B-48 X-2$ & 6 & 8 & 451.5 & 3.89 & 1.2 & VF & silt & & $\ldots S S$ & $T$ & \\
\hline $823 \mathrm{~B}-48 \mathrm{X}-2$ & 14 & 16 & 451.6 & 3.89 & 1.8 & $\mathrm{VF}$ & silt & & ...SS & $T$ & \\
\hline $823 \mathrm{~B}-48 \mathrm{X}-2$ & 23 & 25 & 451.7 & 3.89 & 2 & $\mathrm{VF}$ & silt & & $\ldots$ & $\mathrm{T}$ & \\
\hline $823 \mathrm{~B}-48 \mathrm{X}-2$ & 26 & 31 & 451.7 & 3.89 & 4.8 & $\mathrm{VF}$ & silt & & $\ldots \equiv$ & $\mathrm{T}$ & \\
\hline $823 \mathrm{~B}-48 \mathrm{X}-2$ & 33 & 35 & 451.8 & 3.89 & 1.6 & VF & silt & & $\ldots \equiv$ & $\mathrm{T}$ & \\
\hline $823 B-48 X-2$ & 51 & 54 & 451.9 & 3.89 & 2.4 & $\mathrm{~F}$ & VF & & ...SS & $\mathrm{T}$ & \\
\hline $823 \mathrm{~B}-48 \mathrm{X}-2$ & 117 & 127 & 452.7 & 3.89 & 11 & VF & $\mathrm{M}$ & & OTSS... & $\mathrm{T}$ in $\mathrm{S}$ & \\
\hline $823 \mathrm{~B}-48 \mathrm{X}-2$ & 60 & 150 & 452.9 & 3.89 & 90 & & & & OT $\Omega$ & $\mathrm{S} / 2$ & \\
\hline $823 \mathrm{~B}-48 \mathrm{X}-3$ & 28 & 32 & 453.2 & 3.89 & 2.8 & $\mathrm{~F} / \mathrm{M}$ & VF & & & $\mathrm{T}$ in $\mathrm{S}$ & $?$ \\
\hline $823 \mathrm{~B}-48 \mathrm{X}-3$ & 0 & 32 & 453.2 & 3.89 & 32 & $\mathrm{~F} / \mathrm{M}$ & VF & & & $\mathrm{S} / 2$ & ? \\
\hline $823 B-48 X-3$ & 0 & 32 & 453.2 & 3.89 & 122 & $\mathrm{~F} / \mathrm{M}$ & VF & & & $\mathrm{S}$ & ? \\
\hline $823 B-48 X-3$ & 71 & 74 & 453.6 & 3.89 & 2.8 & silt & mud & & m...sS & $\mathrm{T}$ & \\
\hline $823 B-48 X-3$ & 76 & 79 & 453.7 & 3.89 & 3.3 & $\mathrm{~F}$ & mud & & $\cdots=\$ S$ & $\mathrm{~T}$ & \\
\hline $823 \mathrm{~B}-48 \mathrm{X}-3$ & 84 & 88 & 453.8 & 3.89 & 3.4 & $\mathrm{~F}$ & mud & & ...SS & $\mathrm{T}$ & \\
\hline $823 \mathrm{~B}-48 \mathrm{X}-3$ & 92 & 95 & 453.9 & 3.89 & 3 & VF & mud & & 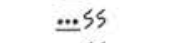 & $T$ & \\
\hline $823 \mathrm{~B}-48 \mathrm{X}-3$ & 99 & 103 & 453.9 & 3.89 & 4 & VF & mud & & ...SS & $T$ & \\
\hline $823 \mathrm{~B}-48 \mathrm{X}-4$ & 0 & 4 & 454.4 & 3.89 & 3.2 & M & & & & $\mathrm{T}$ & \\
\hline $823 \mathrm{~B}-48 \mathrm{X}-4$ & 16 & 25 & 454.7 & 3.89 & 5.8 & F & VF & mud & $\cdots=S S$ & $\mathrm{~T}$ & \\
\hline $823 \mathrm{~B}-48 \mathrm{X}-4$ & 27 & 29 & 454.7 & 3.89 & 1.8 & VF & silt & & $\equiv S 5$ & $T$ & \\
\hline $823 \mathrm{~B}-48 \mathrm{X}-4$ & 42 & 47 & 454.9 & 3.89 & 3 & M & VF & mud & $\cdots=S S$ & $T$ & \\
\hline $823 \mathrm{~B}-48 \mathrm{X}-4$ & 47 & 53 & 454.9 & 3.89 & 4.8 & $\mathrm{M}$ & VF & & $\cdots=55$ & $\mathrm{~T}$ & \\
\hline $823 B-48 X-4$ & 56 & 60 & 455 & 3.89 & 3 & $\mathrm{~F} / \mathrm{M}$ & VF & & ...SS & $T$ & \\
\hline $823 B-48 X-4$ & 83 & 89 & 455.3 & 3.89 & 5.8 & $\mathrm{~F}$ & silt & & $\underline{\cdots}=$ यSS & $\mathrm{T}$ & \\
\hline $823 B-48 X-4$ & 97 & 101 & 455.4 & 3.89 & 3.5 & $\mathrm{~F}$ & VF & & $\underline{\cdots}=S S$ & $T$ & \\
\hline $823 B-48 X-4$ & 110 & 117 & 455.6 & 3.89 & 4 & VF & silt & mud & $\underline{m}=S S$ & $T$ & \\
\hline $823 B-48 X-4$ & 131 & 137 & 455.8 & 3.89 & 5.3 & $\mathrm{~F} / \mathrm{M}$ & silt & & $m m \cdots=S S$ & $\mathrm{~T}$ & \\
\hline $823 B-48 X-4$ & 139 & 141 & 455.8 & 3.89 & 2 & VF & silt/mud & & \#SS & $\mathrm{T}$ & \\
\hline $823 B-48 X-5$ & 47 & 49 & 456.4 & 3.89 & 1.4 & $\mathrm{~F}$ & M & & & $T$ & $?$ \\
\hline $823 \mathrm{~B}-49 \mathrm{X}-1$ & 32 & 33 & 459.9 & 3.89 & 0.5 & VF & $\mathrm{F}$ & & $\equiv$ & $\mathrm{T}$ & $?$ \\
\hline $823 \mathrm{~B}-49 \mathrm{X}-1$ & 39 & 43 & 460 & 3.89 & 1.5 & $\mathrm{~F}$ & $\mathrm{VF}$ & mud & $\cdots=5 s$ & $T$ & \\
\hline $823 \mathrm{~B}-49 \mathrm{X}-1$ & 60 & 62 & 460.2 & 3.89 & 2 & VF & silt & & ...SS & $T$ & \\
\hline $823 \mathrm{~B}-49 \mathrm{X}-1$ & 70 & 86 & 460.5 & 3.89 & 6.6 & $\mathrm{~F}$ & VF & mud & ...SS & $\mathrm{T}$ & \\
\hline $823 B-49 X-1$ & 86 & 150 & 461.1 & 3.89 & 64 & & & & & & $?$ \\
\hline 823B-49X-2 & 33 & 39 & 461.5 & 3.89 & 6 & M & silt & & IN $\ldots$ SS & $T$ & $?$ \\
\hline $823 B-49 X-2$ & 46 & 48 & 461.6 & 3.89 & 1.2 & M & & & & $\mathrm{T}$ & $?$ \\
\hline $823 B-49 X-3$ & 15 & 28 & 462.9 & 3.89 & 13.5 & VF & M & & $=\$ S$ & $T$ & $?$ \\
\hline $823 \mathrm{~B}-49 \mathrm{X}-3$ & 30 & 150 & 464.1 & 3.89 & 120 & & & & $\equiv \Omega S S$ & $\mathrm{~s}$ & ? \\
\hline $823 B-49 X-4$ & 22 & 25 & 464.4 & 3.89 & 3.3 & VF & silt & & $=\cdots m$ SS & $T$ & \\
\hline $823 B-49 X-4$ & 146 & 150 & 465.6 & 3.89 & 4 & VF & mud & & ...SS & $\mathrm{T}$ & \\
\hline $823 B-49 X-5$ & 0 & 6 & 465.7 & 3.89 & 4.8 & $\mathrm{M}$ & VF & & $\cdots=\$ S$ & $T$ & \\
\hline $823 \mathrm{~B}-49 \mathrm{X}-5$ & 20 & 21 & 465.8 & 3.89 & 1.1 & M & $\mathrm{F}$ & & $=m$ & $T$ & \\
\hline
\end{tabular}


Appendix A (continued).

\begin{tabular}{|c|c|c|c|c|c|c|c|c|c|c|c|}
\hline Sample & Top $(\mathrm{cm})$ & $\begin{array}{c}\text { Bottom } \\
(\mathrm{cm})\end{array}$ & Depth (m) & $\begin{array}{l}\text { Age } \\
\text { (ma) }\end{array}$ & Thickness (cm) & Texture Base & Texture Top & Mud cap & $\begin{array}{l}\text { Sedimentary } \\
\text { Structure }\end{array}$ & $\begin{array}{l}\text { Depositional } \\
\text { Mechanism }\end{array}$ & $?$ \\
\hline $823 \mathrm{~B}-49 \mathrm{X}-5$ & 57 & 85 & 466.5 & 3.89 & 9.6 & VF/F & VF/silt & & $=\cdots \times 5 S$ & $\mathrm{~T}$ & \\
\hline $823 \mathrm{~B}-49 \mathrm{X}-5$ & 140 & 150 & 467.1 & 3.89 & 4.1 & silt/mud & & & SS & $\mathrm{T}$ & \\
\hline $823 \mathrm{~B}-49 \mathrm{X}-6$ & 0 & 13 & 467.2 & 3.89 & 5.3 & $\mathrm{VF} / \mathrm{F}$ & $\mathrm{F} /$ silt & & $\operatorname{sm} \cdots=S S$ & $\mathrm{~T}$ & \\
\hline $823 \mathrm{~B}-49 \mathrm{X}-6$ & 46 & 67 & 467.8 & 3.89 & 16.2 & $\mathrm{C}$ & $\mathrm{VF}$ & mud & $M m \cdots=S S$ & $\mathrm{~T}$ & \\
\hline $823 \mathrm{~B}-49 \mathrm{X}-6$ & 77 & 91 & 468 & 3.89 & 4.8 & F & silt & mud & $\underline{\cdots}=\$ S$ & $\mathrm{~T}$ & \\
\hline $823 \mathrm{~B}-49 \mathrm{X}-0$ & 11 & 31 & 468.6 & 3.89 & 18.5 & $1 \mathrm{~cm}(4.5)$ & & & CSBU & DF & \\
\hline $823 \mathrm{~B}-50 \mathrm{X}-1$ & 18 & 36 & 469.6 & 3.89 & 18 & M & VF & & $\cdots \cdots=S S$ & $\mathrm{~T}$ & \\
\hline $823 \mathrm{~B}-50 \mathrm{X}-1$ & 42 & 46 & 469.7 & 3.89 & 3.3 & $\mathrm{~F}$ & VF & mud & $=$ =.S5 & $\mathrm{T}$ & \\
\hline $823 \mathrm{~B}-50 \mathrm{X}-1$ & 85 & 107 & 470.3 & 3.89 & 16.5 & F & silt & mud & $\cdots=\nu \equiv S S$ & $\mathrm{~T}$ & \\
\hline $823 \mathrm{~B}-50 \mathrm{X}-1$ & 119 & 145 & 470.7 & 3.89 & 21 & M & VF/silt & mud & $=\cdots=\nu \equiv S S$ & $\mathrm{~T}$ & \\
\hline $823 \mathrm{~B}-50 \mathrm{X}-1$ & 148 & 150 & 470.7 & 3.89 & 1.5 & VF & mud & & $=\$ S$ & $\mathrm{~T}$ & \\
\hline $823 \mathrm{~B}-50 \mathrm{X}-2$ & 0 & 2 & 470.7 & 3.89 & 2 & $\mathrm{~F}$ & VF & & $=\$ 5$ & $\mathrm{~T}$ & ? \\
\hline $823 \mathrm{~B}-50 \mathrm{X}-2$ & 108 & 119 & 471.9 & 3.89 & 11 & $\mathrm{~F}$ & & & $=\$ S$ & $\mathrm{~T}$ & ? \\
\hline $823 \mathrm{~B}-50 \mathrm{X}-3$ & 25 & 27 & 472.5 & 3.89 & 2.2 & F/VF & mud & & $\underline{m}=\$ S$ & $\mathrm{~T}$ & \\
\hline $823 \mathrm{~B}-50 \mathrm{X}-3$ & 31 & 34 & 472.5 & 3.89 & 1.5 & VF & mud & & ss & $\mathrm{T}$ & \\
\hline $823 \mathrm{~B}-50 \mathrm{X}-3$ & 44 & 46 & 472.7 & 3.89 & 1.7 & VF & silt & & $=S S$ & $T$ & \\
\hline $823 \mathrm{~B}-50 \mathrm{X}-3$ & 57 & 69 & 472.9 & 3.89 & 6.3 & M & VF & mud & $\cdots=\$ S$ & $\mathrm{~T}$ & \\
\hline $823 B-50 X-3$ & 91 & 106 & 473.3 & 3.89 & 7.5 & $\mathrm{~F}$ & silt & & $\ddot{*}=\$ S$ & $\mathrm{~T}$ & \\
\hline $823 B-50 X-3$ & 111 & 122 & 473.4 & 3.89 & 7 & M & silt & mud & $\cdots=\nu S S$ & $\mathrm{~T}$ & \\
\hline $823 B-50 X-3$ & 137 & 141 & 473.6 & 3.89 & 1 & VF & silt & mud & $\underline{\cdots}=S S$ & $\mathrm{~T}$ & \\
\hline $823 \mathrm{~B}-50 \mathrm{X}-0$ & 1 & 4 & 473.7 & 3.89 & 3.5 & VF & & & & $\mathrm{T}$ & \\
\hline $823 \mathrm{~B}-50 \mathrm{X}-0$ & 5 & 10 & 473.8 & 3.89 & 3 & $\mathrm{~F}$ & M & & $=$ & $\mathrm{T}$ & \\
\hline $823 \mathrm{~B}-50 \mathrm{X}-0$ & 17 & 18 & 473.8 & 3.89 & 0.9 & VF & & & $=$ & $\mathrm{T}$ & \\
\hline $823 \mathrm{~B}-52 \mathrm{X}-2$ & 0 & 62 & 489.9 & 3.9 & 212 & & & & 几ms & DF & \\
\hline $823 B-52 X-3$ & 50 & 120 & 492 & 3.93 & 70 & & & & $\Omega \mathbb{N} \equiv$ & $\mathrm{S}$ & \\
\hline $823 B-52 X-4$ & 15 & 18 & 492.5 & 3.93 & 2.8 & F & VF & & $m=\$ 5$ & $\mathrm{~T}$ & \\
\hline $823 B-52 X-4$ & 21 & 23 & 492.5 & 3.93 & 1.8 & $\mathrm{~F}$ & silt & & $\cdots=S S$ & $T$ & \\
\hline $823 B-52 X-4$ & 28 & 29 & 492.6 & 3.93 & 0.6 & VF & silt & & mumm & $\mathrm{T}$ & \\
\hline $823 B-52 X-4$ & 127 & 130 & 493.6 & 3.94 & 2.2 & $\mathrm{~F}$ & silt & & ...SSZZoon & $\mathrm{T}$ & \\
\hline $823 B-52 X-5$ & 54 & 56 & 494.4 & 3.95 & 1.5 & $\mathrm{~F}$ & $\mathrm{M}$ & & $\Omega$ & $\mathrm{T}$ in $\mathrm{S}$ & ? \\
\hline $823 B-52 X-5$ & 65 & 68 & 494.5 & 3.95 & 3 & silt & mud & & SS & $T$ in $S$ & $?$ \\
\hline $823 B-52 X-5$ & 0 & 97 & 494.8 & 3.96 & 97 & & & & & $\mathrm{~S}$ & ? \\
\hline $823 \mathrm{~B}-53 \mathrm{X}-1$ & 26 & 77 & 498.3 & 3.99 & 51 & & & & $\mathbb{N} \equiv \Omega$ & S & $?$ \\
\hline $823 \mathrm{~B}-53 \mathrm{X}-1$ & 84 & 86 & 498.4 & 3.99 & 1.7 & $\mathrm{~F}$ & silt & & $=\cdots$ SS & $T$ & \\
\hline $823 \mathrm{~B}-53 \mathrm{X}-1$ & 129 & 132 & 498.8 & 4 & 2.6 & $\mathrm{~F} / \mathrm{M}$ & silt & & $m m \cdots=S S$ & $\mathrm{~T}$ & \\
\hline $823 \mathrm{~B}-53 \mathrm{X}-1$ & 143 & 144 & 498.9 & 4 & 0.8 & VF & & & $\equiv$ & $\mathrm{T}$ & ? \\
\hline $823 B-53 X-2$ & 18 & 22 & 499.2 & 4 & 2.4 & $\mathrm{VF} / \mathrm{F}$ & silt & & 几...SS & $\mathrm{T}$ & $?$ \\
\hline $823 B-53 X-2$ & 66 & 72 & 499.7 & 4.01 & 3.3 & (VC)M/C & silt & & $m=S S$ & $\mathrm{~T}$ & \\
\hline $823 B-53 X-2$ & 75 & 150 & 500.5 & 4.02 & 75 & & & & $\Omega \mathbb{I N} \equiv \mathbb{B}$ & $\mathrm{S} / 2$ & \\
\hline $823 \mathrm{~B}-53 \mathrm{X}-3$ & 0 & 150 & 502 & 4.03 & 150 & & & & $\Omega \mathbb{I N} \equiv \mathbb{I} / \mathbb{L}$ & $\mathrm{S} / 2$ & \\
\hline $823 B-53 X-4$ & 0 & 104 & 503 & 4.04 & 104 & & & & $\Omega \mathbb{I N} \equiv \mathbb{Z} / \mathbb{L}$ & $\mathrm{S} / 2$ & \\
\hline 823B-53X-5 & 0 & 103 & 504.1 & 4.04 & 103 & & & & $\Omega$ & $\mathrm{S} / 2$ & \\
\hline 823B-53X-5 & 0 & 103 & 504.1 & 4.04 & 432 & & & & $\Omega$ & $\mathrm{s}$ & \\
\hline $823 B-53 X-6$ & 15 & 19 & 504.3 & 4.07 & 1.5 & F & silt & mud & ми…SS & $\mathrm{T}$ & \\
\hline $823 \mathrm{~B}-53 \mathrm{X}-6$ & 22 & 29 & 504.4 & 4.07 & 1 & $\mathrm{~F}$ & silt & mud & ...SS & $T$ & \\
\hline $823 \mathrm{~B}-53 \mathrm{X}-6$ & 34 & 42 & 504.4 & 4.07 & 4.5 & silt & mud & & & $\mathrm{T}$ & \\
\hline 823B-53X-6 & 54 & 55 & 504.5 & 4.07 & 1.6 & $\mathrm{VF}$ & silt & & ...SS & $\mathrm{T}$ & \\
\hline $823 B-53 X-6$ & 101 & 104 & 506 & 4.08 & 1.4 & VF & silt & & S5 & $\mathrm{T}$ & ? \\
\hline $823 \mathrm{~B}-53 \mathrm{X}-6$ & 144 & 147 & 506.5 & 4.08 & 2 & $\mathrm{VF}$ & silt & & SS & & ? \\
\hline $823 \mathrm{~B}-53 \mathrm{X}-7$ & 5 & 11 & 506.6 & 4.08 & 4.8 & VF & silt & & SS & $\mathrm{T}$ & ? \\
\hline $823 \mathrm{~B}-53 \mathrm{X}-8$ & 7 & 10 & 506.9 & 4.08 & 3 & $\mathrm{~F}$ & silt & & $\cdots=S S$ & $\mathrm{~T}$ & \\
\hline $823 B-53 X-7$ & 14 & 36 & 506.9 & 4.08 & 0 & & & & $几 \equiv$ & S & \\
\hline $823 \mathrm{~B}-53 \mathrm{X}-7$ & 42 & 44 & 506.9 & 4.08 & 1.8 & M & VF & & $\cdots=55$ & T & \\
\hline $823 \mathrm{~B}-54 \mathrm{X}-1$ & 9 & 12 & 507.2 & 4.09 & 2.6 & M & silt & & …SS & T & \\
\hline $823 \mathrm{~B}-54 \mathrm{X}-1$ & 21 & 24 & 507.3 & 4.09 & 2 & VF & silt & & \#SS & $\mathrm{T}$ & \\
\hline $823 \mathrm{~B}-54 \mathrm{X}-1$ & 69 & 72 & 507.8 & 4.09 & 2.8 & C & VF & & ..ES5 & $\mathrm{T}$ & \\
\hline $823 \mathrm{~B}-54 \mathrm{X}-1$ & 76 & 82 & 507.9 & 4.1 & 4 & F & silt & & …SS & $\mathrm{T}$ & \\
\hline 823B-53X-0 & 0 & 4 & 508 & 4.1 & 1.6 & $\mathrm{~F}$ & & & & T & \\
\hline $823 \mathrm{~B}-53 \mathrm{X}-0$ & 14 & 17 & 508.2 & 4.1 & 1.1 & VF & silt & & $=S S Z 200$ & $\mathrm{~T}$ & \\
\hline $823 \mathrm{~B}-53 \mathrm{X}-0$ & 19 & 21 & 508.2 & 4.1 & 1.2 & $\mathrm{~F}$ & silt & & …SS & T & \\
\hline $823 \mathrm{~B}-54 \mathrm{X}-1$ & 116 & 123 & 508.3 & 4.1 & 4 & M & VF/silt & & ...SS & $\mathrm{T}$ & \\
\hline $823 \mathrm{~B}-53 \mathrm{X}-0$ & 54 & 55 & 508.6 & 4.1 & 1 & VF & F & & $=$ & $T$ & \\
\hline $823 \mathrm{C}-1 \mathrm{R}-1$ & 150 & 0 & 784 & 6.09 & 150 & & & & $\Omega$ & $\mathrm{S}$ & \\
\hline $823 \mathrm{C}-1 \mathrm{R}-1$ & 125 & 123 & 785.2 & 6.1 & 1.8 & VF & & & & $\mathrm{T}$ & ? \\
\hline $823 \mathrm{C}-1 \mathrm{R}-2$ & 0 & 0 & 785.5 & 6.11 & 0 & & & & & & \\
\hline
\end{tabular}


Appendix A (continued).

\begin{tabular}{|c|c|c|c|c|c|c|c|c|c|c|c|}
\hline Sample & Top $(\mathrm{cm})$ & $\begin{array}{c}\text { Bottom } \\
(\mathrm{cm})\end{array}$ & Depth (m) & $\begin{array}{c}\text { Age } \\
(\mathrm{ma})\end{array}$ & Thickness (cm) & Texture Base & Texture Top & Mud cap & $\begin{array}{c}\text { Sedimentary } \\
\text { Structure }\end{array}$ & $\begin{array}{l}\text { Depositional } \\
\text { Mechanism }\end{array}$ & $?$ \\
\hline $823 \mathrm{C}-1 \mathrm{R}-3$ & 10 & 11 & 787.1 & 6.12 & 1.2 & VF & & & SS & $\mathrm{T}$ & \\
\hline $823 \mathrm{C}-1 \mathrm{R}-3$ & 47 & 48 & 787.5 & 6.13 & 1 & VF & & & ...SS & $\mathrm{T}$ & \\
\hline $823 \mathrm{C}-1 \mathrm{R}-3$ & 53 & 54 & 787.5 & 6.13 & 0.6 & VF & & & $m=$ & $\mathrm{T}$ & \\
\hline $823 \mathrm{C}-1 \mathrm{R}-3$ & 57 & 58 & 787.6 & 6.13 & 1.9 & VF & & & ...SS & $T$ & \\
\hline $823 \mathrm{C}-1 \mathrm{R}-3$ & 130 & 70 & 787.7 & 6.13 & 60 & & & & OT & $\mathrm{s}$ & \\
\hline $823 \mathrm{C}-1 \mathrm{R}-3$ & 90 & 91 & 787.9 & 6.13 & 1.2 & VF & F & & $\bar{N}_{m m}$ & $\mathrm{~T}$ & \\
\hline $823 \mathrm{C}-1 \mathrm{R}-4$ & 27 & 28 & 788.8 & 6.14 & 1 & & & & & $\mathrm{~T}$ & \\
\hline $823 \mathrm{C}-1 \mathrm{R}-4$ & 54 & 53 & 789 & 6.15 & 1 & & & & & $\mathrm{~T}$ & \\
\hline $823 \mathrm{C}-1 \mathrm{R}-5$ & 3 & 4 & 790 & 6.16 & 0.4 & VF & & & $\bar{\ldots}$ & $\mathrm{T}$ & \\
\hline $823 \mathrm{C}-1 \mathrm{R}-5$ & 60 & 61 & 790.6 & 6.16 & 1 & VF & & & $=$ & $\mathrm{T}$ & \\
\hline $823 \mathrm{C}-2 \mathrm{R}-1$ & 0 & 0 & 793.6 & 6.2 & 0 & & & & & $\mathrm{~T}$ & \\
\hline $823 \mathrm{C}-2 \mathrm{R}-1$ & 12 & 14 & 793.7 & 6.2 & 1.7 & $\mathrm{~F}$ & VF & & ...SS & $\mathrm{T}$ & \\
\hline $823 C-2 R-1$ & 37 & 40 & 794 & 6.2 & 3.2 & F & $\mathrm{VF}$ & & мn $\cdots=$ SS & $\mathrm{T}$ & \\
\hline $823 \mathrm{C}-2 \mathrm{R}-1$ & 53 & 55 & 794.2 & 6.21 & 1.8 & $\mathrm{~F}$ & $\mathrm{VF}$ & & мm $\cdots=$ & $\mathrm{T}$ & \\
\hline $823 C-2 R-1$ & 62 & 73 & 794.3 & 6.21 & 11 & M & VF & & $\cdots=\$ S$ & $\mathrm{~T}$ & \\
\hline $823 C-2 R-1$ & 73 & 80 & 794.4 & 6.21 & 7 & M & $\mathrm{F}$ & & $\underline{\cdots}=$ & $\mathrm{T}$ & \\
\hline $823 C-2 R-1$ & 88 & 91 & 794.5 & 6.21 & 3.3 & $\mathrm{~F}$ & VF & & $\cdots=S S$ & $\mathrm{~T}$ & \\
\hline $823 C-2 R-1$ & 91 & 95 & 794.6 & 6.21 & 2.3 & $\mathrm{~F}$ & VF & & min $\otimes S S$ & $\mathrm{~T}$ & \\
\hline $823 \mathrm{C}-2 \mathrm{R}-1$ & 105 & 106 & 794.7 & 6.21 & 0.5 & VF & & & & $\mathrm{T}$ & \\
\hline $823 \mathrm{C}-2 \mathrm{R}-1$ & 116 & 135 & 795 & 6.21 & 19.5 & $\mathrm{~F}$ & VF & & $m=S S$ & $\mathrm{~T}$ & \\
\hline $823 \mathrm{C}-2 \mathrm{R}-1$ & 147 & 148 & 795.1 & 6.22 & 0.7 & VF & & & $\operatorname{musS}$ & $\mathrm{T}$ & \\
\hline $823 \mathrm{C}-2 \mathrm{R}-2$ & 6 & 7 & 795.2 & 6.22 & 1 & VF & & & SS & $\mathrm{T}$ & \\
\hline $823 C-2 R-2$ & 8 & 11 & 795.2 & 6.22 & 1 & VF & & & m & $\mathrm{T}$ & \\
\hline $823 C-2 R-2$ & 15 & 18 & 795.3 & 6.22 & 2 & $\mathrm{~F}$ & VF & & SS & $\mathrm{T}$ & \\
\hline $823 \mathrm{C}-2 \mathrm{R}-2$ & 30 & 46 & 795.6 & 6.22 & 16 & F & M & VF & sm $\cdots=S S$ & $\mathrm{~T}$ & \\
\hline $823 C-2 R-2$ & 48 & 49 & 795.6 & 6.22 & 1 & $\mathrm{~F}$ & & & & $\mathrm{~T}$ & \\
\hline $823 C-2 R-2$ & 62 & 68 & 795.8 & 6.22 & 6 & M & VF & & $m \cdots=\nu S S$ & $\mathrm{~T}$ & \\
\hline $823 C-2 R-2$ & 69 & 75 & 795.9 & 6.22 & 6.4 & $M$ & $\mathrm{~F}$ & & $m n \cdots=2 \infty$ & $\mathrm{T}$ & \\
\hline $823 \mathrm{C}-2 \mathrm{R}-2$ & 88 & 87 & 796 & 6.23 & 8.6 & $\mathrm{~F}$ & VF & & $\ddot{m}=$ & $\mathrm{T}$ & \\
\hline $823 C-2 R-2$ & 99 & 105 & 796.2 & 6.23 & 6.3 & $\mathrm{~F}$ & $\mathrm{VF}$ & & $=\ldots$..SS & $\mathrm{T}$ & \\
\hline $823 \mathrm{C}-2 \mathrm{R}-2$ & 111 & 114.5 & 796.2 & 6.23 & 3.7 & $\mathrm{~F}$ & VF & & $m \ddot{\cdots}=\nu$ & $\mathrm{T}$ & \\
\hline $823 \mathrm{C}-2 \mathrm{R}-2$ & 122 & 123 & 796.3 & 6.23 & 0.6 & VF & & & $m=$ & $\mathrm{T}$ & \\
\hline $823 \mathrm{C}-2 \mathrm{R}-2$ & 129 & 134 & 796.4 & 6.23 & 5 & $\mathrm{~F}$ & VF & & $\ddot{\cdots}=\nu$ & $\mathrm{T}$ & \\
\hline $823 \mathrm{C}-2 \mathrm{R}-2$ & 136 & 141 & 796.5 & 6.23 & 5 & $\mathrm{~F}$ & VF & & $\underline{\cdots}=$ & $\mathrm{T}$ & \\
\hline $823 \mathrm{C}-2 \mathrm{R}-2$ & 143 & 146 & 796.6 & 6.23 & 2.5 & VF & silt & & $\cdots=\nu$ & $\mathrm{T}$ & \\
\hline $823 C-2 R-2$ & 149 & 150 & 796.6 & 6.23 & 1 & VF & silt & & & $\mathrm{T}$ & \\
\hline $823 C-2 R-3$ & 0 & 6.5 & 796.7 & 6.23 & 6.5 & $\mathrm{~F}$ & VF & & $=\underline{\cdots}$ & $\mathrm{T}$ & \\
\hline $823 C-2 R-3$ & 46 & 47 & 797.1 & 6.24 & 1 & VF & silt & & $=\cdots$ & $\mathrm{T}$ & \\
\hline $823 \mathrm{C}-2 \mathrm{R}-3$ & 60 & 50 & 797.1 & 6.24 & 10 & $\mathrm{~F}$ & VF & silt & $=\cdots$ & $T$ & \\
\hline $823 C-2 R-3$ & 67 & 68 & 797.3 & 6.24 & 1.1 & VF & silt & & мm… $\equiv$ & $\mathrm{T}$ & \\
\hline $823 C-2 R-3$ & 99 & 103 & 797.6 & 6.25 & 4 & VF & silt & & $\underline{\cdots}=$ & $\mathrm{T}$ & \\
\hline $823 \mathrm{C}-2 \mathrm{R}-3$ & 121 & 120 & 797.8 & 6.25 & 1 & & & & S5 & $\mathrm{T}$ & \\
\hline $823 \mathrm{C}-2 \mathrm{R}-4$ & 27 & 40 & 798.5 & 6.26 & 13 & F & VF & & $\cdots=S S$ & $\mathrm{~T}$ & \\
\hline $823 \mathrm{C}-2 \mathrm{R}-4$ & 64 & 70 & 798.8 & 6.26 & 6.1 & & & & 55 & & \\
\hline $823 C-2 R-4$ & 70 & 109 & 799.2 & 6.26 & 39 & & & & SS & & \\
\hline $823 C-3 R-1$ & 39 & 43 & 803.3 & 6.31 & 1.6 & VF & silt & & mSSSZOo & $\mathrm{T}$ & \\
\hline $823 C-3 R-1$ & 82 & 59 & 803.5 & 6.31 & 23 & & & & $\mathrm{CS} \Omega$ & DF & ? \\
\hline $823 \mathrm{C}-3 \mathrm{R}-1$ & 87 & 88 & 803.8 & 6.32 & 1 & VF & & & & $\mathrm{T}$ & \\
\hline $823 C-3 R-1$ & 111 & 117 & 804.1 & 6.32 & 2.1 & $\mathrm{VF}$ & & & $=\nu S S$ & $\mathrm{~T}$ & \\
\hline $823 C-3 R-1$ & 127 & 131 & 804.2 & 6.32 & 2.4 & VF & & & NSS & $\mathrm{T}$ & \\
\hline $823 \mathrm{C}-3 \mathrm{R}-1$ & 131 & 134 & 804.2 & 6.32 & 1.1 & VF & & & muSS & $\mathrm{T}$ & \\
\hline $823 C-3 R-1$ & 139 & 142 & 804.3 & 6.32 & 3 & $\mathrm{~F}$ & VF & & ...SS & $\mathrm{T}$ & \\
\hline $823 C-3 R-1$ & 142 & 150 & 804.4 & 6.32 & 7 & $\mathrm{M}$ & $\mathrm{F}$ & & CS… & $\mathrm{T}$ & \\
\hline $823 C-3 R-2$ & 0 & 0 & 804.4 & 6.32 & 0 & & & & & $\mathrm{~T}$ & \\
\hline $823 C-3 R-2$ & 4.5 & 7 & 804.5 & 6.32 & 2.5 & $\mathrm{~F}$ & silt & & ‥ & $T$ & \\
\hline $823 C-3 R-2$ & 9.5 & 14 & 804.5 & 6.32 & 4.3 & $\mathrm{~F}$ & VF & & $\cdots=\$ S$ & $\mathrm{~T}$ & \\
\hline $823 \mathrm{C}-3 \mathrm{R}-2$ & 14 & 17 & 804.6 & 6.33 & 1.9 & VF & silt & & $=\cdots$ & $\mathrm{T}$ & \\
\hline $823 \mathrm{C}-3 \mathrm{R}-2$ & 25 & 27 & 804.7 & 6.33 & 1.6 & VF & silt & & ...SS & $\mathrm{T}$ & \\
\hline $823 C-3 R-2$ & 28.5 & 31 & 804.7 & 6.33 & 0.5 & VF & & & SS & $\mathrm{T}$ & \\
\hline $823 C-3 R-2$ & 31 & 34 & 804.7 & 6.33 & 1.3 & $\mathrm{VF}$ & silt & & SS & $\mathrm{T}$ & \\
\hline $823 \mathrm{C}-3 \mathrm{R}-2$ & 43 & 55 & 805 & 6.33 & 10 & $\mathrm{M}$ & VF & & $\ddot{m}=$ & $\mathrm{T}$ & \\
\hline $823 C-3 R-2$ & 56 & 59 & 805 & 6.33 & 2.5 & VF & & & $M=\cdots$ & $T$ & \\
\hline $823 \mathrm{C}-3 \mathrm{R}-2$ & 65 & 68 & 805.1 & 6.33 & 0.5 & VF & silt & & $=$ & $\mathrm{T}$ & \\
\hline $823 \mathrm{C}-3 \mathrm{R}-2$ & 91 & 93 & 805.3 & 6.33 & 1.1 & VF & & & $=\underline{\cdots}$ & $\mathrm{T}$ & \\
\hline $823 \mathrm{C}-3 \mathrm{R}-2$ & 95 & 98 & 805.4 & 6.33 & 4.4 & $\mathrm{~F}$ & VF & & $\cdots=S S$ & $\mathrm{~T}$ & \\
\hline
\end{tabular}


Appendix A (continued).

\begin{tabular}{|c|c|c|c|c|c|c|c|c|c|c|c|}
\hline Sample & Top $(\mathrm{cm})$ & $\begin{array}{c}\text { Bottom } \\
(\mathrm{cm})\end{array}$ & Depth (m) & $\begin{array}{l}\text { Age } \\
\text { (ma) }\end{array}$ & Thickness (cm) & Texture Base & Texture Top & Mud cap & $\begin{array}{l}\text { Sedimentary } \\
\text { Structure }\end{array}$ & $\begin{array}{l}\text { Depositional } \\
\text { Mechanism }\end{array}$ & $?$ \\
\hline $823 \mathrm{C}-3 \mathrm{R}-3$ & 18 & 20 & 806.1 & 6.34 & 1.4 & $\mathrm{VF}$ & silt & & $5 s$ & $\mathrm{~T}$ & \\
\hline $823 C-3 R-3$ & 50 & 54 & 806.4 & 6.35 & 4 & & & & & $\mathrm{~T}$ & \\
\hline $823 \mathrm{C}-3 \mathrm{R}-3$ & 54 & 58 & 806.5 & 6.35 & 4 & & & & & $\mathrm{~T}$ & \\
\hline $823 C-3 R-3$ & 58 & 62 & 806.5 & 6.35 & 4 & & & & & $\mathrm{~T}$ & \\
\hline $823 C-3 R-3$ & 86 & 92 & 806.8 & 6.35 & 6 & VF & silt & & $\cdots=S S$ & $\mathrm{~T}$ & \\
\hline $823 C-3 R-3$ & 117 & 119 & 807.1 & 6.35 & 1.6 & VF & silt & & ми… & $\mathrm{T}$ & \\
\hline $823 C-3 R-3$ & 132 & 137 & 807.3 & 6.36 & 5 & & & & & $\mathrm{~T}$ & \\
\hline $823 C-3 R-4$ & 83 & 89 & 808.3 & 6.37 & 5.5 & M & F & & $\underline{\cdots}$ & $\mathrm{T}$ & \\
\hline $823 C-3 R-4$ & 89 & 150 & 808.9 & 6.38 & 61 & M & $\mathrm{F}$ & VF & $=S S$ & $\mathrm{~T}$ & \\
\hline $823 \mathrm{C}-4 \mathrm{R}-0$ & 0 & 2 & 811.1 & 6.4 & 1.5 & $\mathrm{~F}$ & VF & & $m \cdots \cdots=$ & & \\
\hline $823 \mathrm{C}-4 \mathrm{R}-0$ & 9 & 12 & 811.2 & 6.4 & 3 & VF & $\mathrm{F}$ & & $\bar{\cdots}=S S$ & $\mathrm{~T}$ & \\
\hline $823 \mathrm{C}-4 \mathrm{R}-0$ & 24 & 25 & 811.4 & 6.4 & 1 & VF & & & $\mathrm{sm} \cdots=5 S$ & $\mathrm{~T}$ & \\
\hline $823 \mathrm{C}-4 \mathrm{R}-0$ & 32 & 33 & 811.4 & 6.4 & 1.1 & $\mathrm{~F}$ & VF & & $\underline{\cdots}$ & $\mathrm{T}$ & \\
\hline $823 \mathrm{C}-4 \mathrm{R}-1$ & 21 & 22 & 812.8 & 6.42 & 1.1 & $\mathrm{~F} / \mathrm{M}$ & & & & $\mathrm{T}$ & \\
\hline $823 \mathrm{C}-4 \mathrm{R}-1$ & 46 & 48 & 813.1 & 6.42 & 1.6 & $\mathrm{~F} / \mathrm{M}$ & & & & $\mathrm{T}$ & \\
\hline $823 \mathrm{C}-4 \mathrm{R}-2$ & 0 & 0 & 814.1 & 6.44 & 0 & & & & & & \\
\hline $823 C-4 R-2$ & 22 & 20 & 814.3 & 6.44 & 2 & & & & & $\mathrm{~T}$ & \\
\hline $823 \mathrm{C}-4 \mathrm{R}-2$ & 54 & 55 & 814.7 & 6.44 & 0.4 & VF & & & & $\mathrm{T}$ & \\
\hline $823 \mathrm{C}-4 \mathrm{R}-2$ & 108 & 110 & 815.2 & 6.45 & 2 & & & & & $\mathrm{~T}$ & \\
\hline $823 \mathrm{C}-4 \mathrm{R}-2$ & 132 & 131 & 815.4 & 6.45 & 1 & & & & & $T$ & \\
\hline $823 C-4 R-3$ & 25 & 30 & 815.9 & 6.46 & 5.2 & $\mathrm{~F} / \mathrm{M}$ & F & & mm...S5 & $\mathrm{T}$ & \\
\hline $823 C-4 R-3$ & 40 & 41 & 816 & 6.46 & 0.7 & F/M & & & & $\mathrm{T}$ & \\
\hline $823 C-4 R-3$ & 87 & 91 & 816.5 & 6.46 & 4.2 & $\mathrm{~F}$ & & & & $\mathrm{~T}$ & \\
\hline $823 C-4 R-3$ & 116 & 117 & 816.8 & 6.47 & 1.2 & VF & $\mathrm{F}$ & & mnSS & $\mathrm{T}$ & ? \\
\hline $823 C-4 R-4$ & 82 & 92 & 818 & 6.48 & 10 & $\mathrm{VF} / \mathrm{F}(\mathrm{m})$ & & & $=$ & & \\
\hline $823 \mathrm{C}-4 \mathrm{R}-4$ & 103 & 106 & 818.2 & 6.48 & 3.3 & & & & & $\mathrm{~T}$ & \\
\hline $823 C-4 R-4$ & 110 & 107 & 818.2 & 6.48 & 3 & & & & & $\mathrm{~T}$ & \\
\hline $823 C-4 R-4$ & 120 & 122 & 818.3 & 6.48 & 2.2 & & & & & $T$ & \\
\hline $823 C-4 R-4$ & 148 & 150 & 818.6 & 6.49 & 2 & VF & & & & & \\
\hline $823 C-5 R-2$ & 0 & 0 & 823.8 & 6.55 & 0 & & & & & & \\
\hline $823 C-5 R-2$ & 4 & 5 & 823.9 & 6.55 & 0.1 & VF & & & $\ldots$ & $\mathrm{T}$ & \\
\hline $823 C-5 R-2$ & 29 & 30 & 824.1 & 6.55 & 0.4 & VF & & & & $T$ & \\
\hline $823 C-5 R-2$ & 33 & 34 & 824.1 & 6.55 & 0.6 & VF & & & & $\mathrm{T}$ & \\
\hline $823 C-5 R-2$ & 38 & 39 & 824.2 & 6.55 & 0.5 & VF & F & & \#OT & $\mathrm{T}$ & \\
\hline $823 C-5 R-2$ & 39 & 40 & 824.2 & 6.55 & 0.4 & VF & F & & \#OT & $\mathrm{T}$ & \\
\hline $823 C-5 R-2$ & 89 & 111 & 824.9 & 6.56 & 22 & & & & CS & $D F$ to $S$ & \\
\hline $823 C-5 R-2$ & 150 & 140 & 825.2 & 6.56 & 10 & VF & & & $\Omega$ & $\mathrm{S}$ & \\
\hline $823 C-5 R-3$ & 20 & 0 & 825.3 & 6.56 & 20 & & & & & $\mathrm{~s}$ & \\
\hline $823 C-5 R-6$ & 0 & 0 & 829.8 & 6.62 & 0 & & & & & & \\
\hline $823 C-5 R-6$ & 0 & 0 & 829.8 & 6.62 & 0 & & & & & & \\
\hline $823 C-5 R-6$ & 0 & 0 & 829.8 & 6.62 & 0 & & & & & & \\
\hline $823 \mathrm{C}-6 \mathrm{R}-1$ & 4 & 0 & 832 & 6.64 & 3.4 & $\mathrm{~F}(\mathrm{VCO}$ & & & 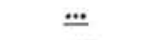 & $T$ & \\
\hline $823 \mathrm{C}-6 \mathrm{R}-1$ & 6 & 4 & 832 & 6.64 & 1.2 & $\mathrm{~F}(\mathrm{VC})$ & & & 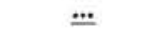 & $\mathrm{T}$ & \\
\hline $823 \mathrm{C}-6 \mathrm{R}-2$ & 0 & 0 & 833.5 & 6.66 & 0 & & & & & & \\
\hline $823 \mathrm{C}-6 \mathrm{R}-2$ & 0 & 0 & 833.5 & 6.66 & 0 & & & & & & \\
\hline $823 C-6 R-2$ & 25 & 34 & 833.8 & 6.66 & 8.5 & M & $\mathrm{VF}$ & & $m m \cdots=\nu S S$ & $\mathrm{~T}$ & \\
\hline $823 \mathrm{C}-7 \mathrm{R}-1$ & 25 & 34 & 842 & 6.76 & 8.5 & M & VF & & $m m \cdots=\nu S S$ & $\mathrm{~T}$ & \\
\hline $823 \mathrm{C}-7 \mathrm{R}-1$ & 34 & 83 & 842.5 & 6.76 & 48.5 & & & & ms & DF & \\
\hline $823 \mathrm{C}-7 \mathrm{R}-1$ & 83 & 87 & 842.6 & 6.76 & 4 & VF & & & $s s \equiv$ & $\mathrm{T}$ & \\
\hline $823 \mathrm{C}-7 \mathrm{R}-1$ & 87 & 89 & 842.6 & 6.76 & 2 & $\mathrm{~F}$ & VF & & S5 & $T$ & \\
\hline $823 \mathrm{C}-7 \mathrm{R}-1$ & 89 & 94 & 842.6 & 6.76 & 5.2 & F & VF & & $=\nu 5 S$ & $\mathrm{~T}$ & \\
\hline $823 \mathrm{C}-7 \mathrm{R}-1$ & 99 & 101 & 842.7 & 6.76 & 1.8 & F & VF & & S5 & $\mathrm{T}$ & \\
\hline $823 \mathrm{C}-7 \mathrm{R}-1$ & 101 & 103 & 842.7 & 6.76 & 2 & $\mathrm{~F}$ & VF & & $=S S \equiv$ & $\mathrm{T}$ & \\
\hline $823 C-7 R-1$ & 135 & 148 & 843.2 & 6.77 & 14.5 & M & VF & & $\cdots=S S$ & $\mathrm{~T}$ & \\
\hline $823 C-7 R-2$ & 24 & 21 & 843.4 & 6.77 & 3 & M & VF & & $\underline{\cdots}=$ & $\mathbf{T}$ & \\
\hline $823 \mathrm{C}-7 \mathrm{R}-2$ & 40 & 24 & 843.4 & 6.77 & 16 & & & & & DF & \\
\hline $823 C-7 R-3$ & 0 & 0 & 844.7 & 6.79 & 0 & & & & & & \\
\hline $823 C-7 R-3$ & 7 & 10 & 844.8 & 6.79 & 3.2 & & & & & & \\
\hline $823 \mathrm{C}-7 \mathrm{R}-3$ & 51 & 63 & 845.3 & 6.79 & 11.5 & M & VF & & $m=\$ S$ & $\mathrm{~T}$ & \\
\hline $823 \mathrm{C}-7 \mathrm{R}-3$ & 63 & 65 & 845.4 & 6.79 & 1.3 & $\mathrm{~F}$ & $\mathrm{VF}$ & & ‥ & $\mathrm{T}$ & \\
\hline $823 C-7 R-3$ & 76 & 83 & 845.5 & 6.8 & 7 & M & $\mathrm{F}$ & VF & $M m \cdots=\nu S S$ & $\mathrm{~T}$ & \\
\hline $823 \mathrm{C}-7 \mathrm{R}-3$ & 88 & 89 & 845.6 & 6.8 & 1 & VF & & & & $\mathrm{T}$ & \\
\hline $823 \mathrm{C}-7 \mathrm{R}-3$ & 96 & 98 & 845.7 & 6.8 & 2.8 & $\mathrm{~F}$ & VF & & $\underline{\cdots}=S S$ & $\mathrm{~T}$ & \\
\hline $823 C-7 R-3$ & 106 & 110 & 845.8 & 6.8 & 4 & $\mathrm{~F}$ & VF/silt & & $\underline{\cdots}=\nu S S$ & $\mathrm{~T}$ & \\
\hline $823 C-7 R-3$ & 110 & 112 & 845.8 & 6.8 & 2 & VF & silt & & ...SS & $T$ & \\
\hline
\end{tabular}


Appendix A (continued).

\begin{tabular}{|c|c|c|c|c|c|c|c|c|c|c|c|}
\hline Sample & Top $(\mathrm{cm})$ & $\begin{array}{c}\text { Bottom } \\
(\mathrm{cm})\end{array}$ & Depth (m) & $\begin{array}{l}\text { Age } \\
\text { (ma) }\end{array}$ & Thickness (cm) & Texture Base & Texture Top & Mud cap & $\begin{array}{c}\text { Sedimentary } \\
\text { Structure }\end{array}$ & $\begin{array}{l}\text { Depositional } \\
\text { Mechanism }\end{array}$ & $?$ \\
\hline $823 \mathrm{C}-7 \mathrm{R}-4$ & 0 & 0 & 846.2 & 6.8 & 0 & & & & & & \\
\hline $823 C-7 R-4$ & 9 & 11 & 846.3 & 6.81 & 2 & VF & silt & & $=S S$ & $\mathrm{~T}$ & \\
\hline $823 \mathrm{C}-7 \mathrm{R}-4$ & 16 & 17 & 846.4 & 6.81 & 1.3 & VF & & & 55 & $\mathrm{~T}$ & \\
\hline $823 C-7 R-4$ & 61 & 41 & 846.6 & 6.81 & 19.5 & F & VF & & $\psi=\$ S$ & $\mathrm{~T}$ & \\
\hline $823 C-7 R-4$ & 61 & 71 & 846.9 & 6.81 & 9.5 & $\mathrm{M} / \mathrm{C}$ & $\mathrm{F} / \mathrm{M}$ & & $\operatorname{mn} \cdots=$ & $\mathrm{T}$ & \\
\hline $823 \mathrm{C}-7 \mathrm{R}-4$ & 71 & 150 & 847.7 & 6.82 & 79 & & & & $\mathrm{~ms}$ & DF & \\
\hline $823 C-7 R-5$ & 66 & 0 & 847.7 & 6.82 & 66 & & & & $\mathrm{CS} \Omega$ & DF & \\
\hline $823 C-7 R-5$ & 90 & 96 & 848.7 & 6.83 & 5.5 & VF & & & $\underline{\cdots}=$ & $\mathrm{T}$ & \\
\hline $823 C-7 R-5$ & 106 & 111 & 848.8 & 6.83 & 5.1 & $\mathrm{~F}$ & VF & & $\cdots=S S$ & $\mathrm{~T}$ & \\
\hline $823 C-7 R-5$ & 111 & 112 & 848.8 & 6.83 & 0.5 & VF & $\mathrm{F}$ & & 55 & $\mathrm{~T}$ & \\
\hline $823 C-7 R-5$ & 147 & 150 & 849.2 & 6.84 & 2.5 & $\mathrm{~F}$ & VF & & $\underline{* *}=S S$ & $\mathrm{~T}$ & \\
\hline $823 C-7 R-6$ & 49 & 0 & 849.2 & 6.84 & 49 & M & VF & & $=\cdots \cdots 20055$ & $\mathrm{~T}$ & \\
\hline $823 C-7 R-6$ & 69 & 49.5 & 849.7 & 6.84 & 19.5 & & & & $C S=\ldots$ & $\mathrm{T}$ & \\
\hline $823 C-7 R-6$ & 75 & 69 & 849.9 & 6.85 & 6 & M & & & w & $\mathrm{T}$ & \\
\hline $823 \mathrm{C}-8 \mathrm{R}-1$ & 141 & 150 & 852.9 & 6.88 & 8.5 & $\mathrm{M} / \mathrm{F}$ & VF & & $=\gg$ & $\mathrm{T}$ & \\
\hline $823 C-8 R-2$ & 0 & 12 & 853 & 6.88 & 12 & $\mathrm{M}$ & $\mathrm{F}$ & & $\ddot{\cdots}=\nu$ & $\mathrm{T}$ & \\
\hline $823 \mathrm{C}-9 \mathrm{R}-1$ & 115 & 116 & 862.3 & 6.99 & 1.1 & $\mathrm{~F}$ & & & & & \\
\hline $823 \mathrm{C}-9 \mathrm{R}-1$ & 123 & 124 & 862.3 & 6.99 & 0.8 & F & VF & & $\underline{\cdots}$ & $\mathrm{T}$ & \\
\hline $823 \mathrm{C}-9 \mathrm{R}-1$ & 138 & 150 & 862.6 & 6.99 & 12.1 & M & $\mathrm{F}$ & M & $=$ & $\mathrm{T}$ & \\
\hline $823 \mathrm{C}-9 \mathrm{R}-2$ & 0 & 5 & 862.7 & 6.99 & 4.5 & F & M & & & $\mathrm{T}$ & \\
\hline $823 C-9 R-2$ & 36 & 37 & 863 & 7 & 0.8 & $\mathrm{~F}$ & & & $\ddot{\cdots}=$ & $\mathrm{T}$ & \\
\hline $823 \mathrm{C}-9 \mathrm{R}-2$ & 45 & 47 & 863.1 & 7 & 1.5 & F & VF & & ...SS & $\mathrm{T}$ & \\
\hline $823 C-9 R-2$ & 76 & 78 & 863.4 & 7 & 2 & $\mathrm{~F}$ & VF & & \#SS & $\mathrm{T}$ & \\
\hline $823 C-9 R-2$ & 80 & 82 & 863.4 & 7 & 1.6 & & & & & & \\
\hline
\end{tabular}


APPENDIX B

Petrographic Data for Site 823

\begin{tabular}{|c|c|c|c|}
\hline \multicolumn{2}{|c|}{ Skeletal Grains } & \multicolumn{2}{|c|}{ Other Components } \\
\hline 8 & Foraminifers (total) & M & Matrix \\
\hline (8) & Globigerinid foraminifers & $\mathrm{C}$ & Cement \\
\hline$\theta$ & Keeled planktic foraminifers & & \\
\hline$B$ & Neritic foraminifers & & \\
\hline 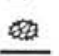 & Large neritic foraminifers & & \\
\hline $\bar{B}$ & Total bioclasts & \multicolumn{2}{|c|}{ Other Grain Types } \\
\hline$c$ & Bioclasts (undif.) & $\Sigma$ & Limeclast \\
\hline 8 & Gastropods & $\odot$ & Mud intraclast \\
\hline$\theta$ & Pteropods & & \\
\hline$\theta$ & Ostracods & & \\
\hline $\mathrm{T}$ & Tunicates & & \\
\hline$\diamond$ & Bivalves & \multicolumn{2}{|c|}{ Non-carbonate material } \\
\hline$\not{x}$ & Echinoderms & $Q$ & Detrital quartz \\
\hline$\approx$ & Algae (undif.) & $\mathrm{Fp}$ & Plagioclase \\
\hline HH & Coralline red algae & $\mathrm{Fk}$ & K-feldspar \\
\hline A & Halimeda & L & Lithic fragments \\
\hline y & Bryozoans & Ls & Sedimentary \\
\hline 3 & Corals & Lm & Metamorphic \\
\hline$*$ & Sponge spicules & $\mathrm{Li}$ & Igneous \\
\hline$\approx$ & Sponges & $\mathrm{G}$ & Glauconite \\
\hline$\infty$ & Fish bones & $\mathrm{P}$ & Phosphate \\
\hline \multicolumn{2}{|c|}{ Abundant $=>30 \%$, } & \multicolumn{2}{|c|}{ Few $=3-10 \%, \quad$ Rare $=<3 \%$} \\
\hline
\end{tabular}


Appendix B (continued).

\begin{tabular}{|c|c|c|c|c|c|c|c|c|c|}
\hline Sample & $\begin{array}{c}\text { Depth } \\
\text { (m) }\end{array}$ & $\begin{array}{c}\text { Age } \\
\text { (ma) }\end{array}$ & Abundant & Common & Few & Rare & Rock Types & Carbonate Texture & Depositional Mechanism \\
\hline $823 \mathrm{~A}-1-2-32$ & 1.82 & 0.02 & Q & & & $B A L F, \forall \otimes B A \theta$ & mixed sandstone & Grainstone & turbidite \\
\hline $823 \mathrm{~A}-1-4-97$ & 5.47 & 0.061 & $\mathrm{BC}$ & $T \oplus 8$ & $M Q \neq \Delta \phi$ & $\theta G \theta A$ & limestone, bioclastic, foraminiferal & Grainstone & turbidite \\
\hline $823 \mathrm{~A}-2-7-10$ & 14.9 & 0.305 & $B C$ & 98 & QM & $\star \mathrm{L} E \mathrm{~T}$ & limestone, bioclastic, foraminiferal & Grainstone & turbidite \\
\hline $823 \mathrm{~A}-2-0-0$ & 15.32 & 0.31 & $\mathrm{BC}$ & (28) & $T M \theta O$ & $G Q B$ & limestone, bioclastic, foraminiferal & Grainstone, Packstone & turbidite \\
\hline $823 \mathrm{~A}-3-4-58$ & 20.38 & 0.358 & BM & 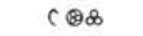 & $* \cos T *$ & $G P L \theta A$ & foraminiferal ooze, bioclastic & Packstone & debris flow \\
\hline $823 \mathrm{~A}-3-6-52$ & 23.32 & 0.386 & $B C$ & 88 & $C Q \star M$ & $P G \theta$ & limestone, bioclastic, foraminiferal & Packstone & turbidite \\
\hline $823 \mathrm{~A}-4-1-60$ & 25.4 & 0.406 & $B C$ & & $M \star Q C \otimes \& T \&$ & $p \theta$ & limestone, bioclastic & Grainstone & turbidite \\
\hline $823 \mathrm{~A}-4-5-37$ & 31.17 & 0.462 & $B \otimes 8$ & QC & 0 & $T \star L 8 \theta \theta \oplus$ & limestone, bioclastic, foraminiferal, quartzose & Grainstone & turbidite \\
\hline $823 \mathrm{~A}-4-6-109$ & 33.39 & 0.477 & $Q_{B}$ & MC & 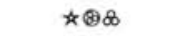 & GPC & mixed sandstone, bioclastic & Grainstone & turbidite \\
\hline $823 \mathrm{~A}-5-2-29$ & 36.09 & 0.49 & $Q_{B}$ & MCT & $\checkmark \star C \otimes \otimes \Delta$ & GP $8 \mathrm{~L}$ & mixed sandstone, bioclastic & Grainstone & turbidite \\
\hline 823A-5-3-144 & 38.74 & 0.503 & (18) & M & $\theta$ & $C B \triangle \not$ & foraminiferal ooze & Packstone & hemipelagic? \\
\hline $823 \mathrm{~A}-5-5-35$ & 40.65 & 0.513 & B & (3) & MCQ*OT\# & $B \mathrm{G} \theta B$ & limestone, bioclastic, foraminiferal & Grainstone & turbidite \\
\hline $823 \mathrm{~A}-5-6-110$ & 42.9 & 0.524 & 98 & $B M C$ & 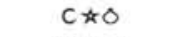 & $Q G D O B *$ & foraminiferal ooze, bioclastic & Packstone & turbidite \\
\hline $823 \mathrm{~A}-6-3-69$ & 47.49 & 0.547 & B \& & CT@ & Mas & $G P F, \theta B$ & foraminiferal ooze, bioclastic & Packstone & turbidite \\
\hline $823 A-6-3-139$ & 48.19 & 0.55 & B & $M C Q \Delta \otimes C$ & $\star T$ & $\triangle G P \theta B A$ & limestone, bioclastic, foraminiferal, quartzose & Grainstone & turbidite \\
\hline $823 \mathrm{~A}-6-7-44$ & 53.24 & 0.576 & M & (28) & B T & CQPPिBठ & mixed mudstone, foraminiferal & Wackestone & hemipelagic \\
\hline $823 \mathrm{~A}-7-4-90$ & 58.7 & 0.609 & B & C CT\&O & *Ma১/म & 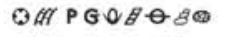 & foraminiferal ooze, quartzose & Packstone & turbidite to debris flow \\
\hline $823 \mathrm{~A}-7-5-76$ & 60.06 & 0.629 & M & $T \otimes 8$ & B & \#acor & mixed mudstone, foraminiferal & Wackestone & hemipelagic \\
\hline $823 \mathrm{~A}-8-2-144$ & 65.74 & 0.714 & M & (28) & BT & $Q L P \theta \Delta C$ & mixed mudstone, foraminiferal & Wackestone & hemipelagic \\
\hline $823 \mathrm{~A}-8-3-77$ & 66.57 & 0.726 & B & $\mathrm{CQBO}$ & \#MPQRT & G & limestone, bioclastic, foraminiferal, quartzose & Grainstone & turbidite \\
\hline 823A-9-3-57 & 75.87 & 0.865 & M & C BDOB & CQPOA & $\infty \times \theta$ & foraminiferal ooze, bioclastic & Packstone & slump \\
\hline $823 \mathrm{~A}-9-7-17$ & 81.47 & 0.944 & B & CबB & 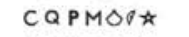 & $G * \theta$ & limestone, bioclastic, foraminiferal & Grainstone & turbidite \\
\hline $823 \mathrm{~A}-10-3-58$ & 85.38 & 0.987 & B & $\mathrm{cc}$ & ॠMQTB@১ & $G P \theta \theta$ & limestone, bioclastic & Grainstone & turbidite \\
\hline $823 \mathrm{~A}-10-4-37$ & 86.67 & 1.002 & $\infty$ & $Q_{B} \otimes$ & $C \star \Delta \theta \theta$ & $P G \oplus$ & limestone, bioclastic, foraminiferal, quartzose & Grainstone, Packstone & turbidite \\
\hline $823 \mathrm{~A}-11-1-64$ & 91.94 & 1.06 & (98) & M & $B Q C C$ & GPLEL & foraminiferal ooze & Packstone & turbidite \\
\hline $823 \mathrm{~A}-11-3-60$ & 94.9 & 1.093 & $B C$ & a & $\not(98$ & $C G P M B \& A F$ & limestone, bioclastic, quartzose & Grainstone & turbidite \\
\hline $823 \mathrm{~A}-11-6-32$ & 99.12 & 1.16 & M & (19) & aB $C$ & $G P \theta \star$ & mixed mudstone, foraminiferal & Wackestone & hemipelagic \\
\hline $823 \mathrm{~A}-12-2-91$ & 103.21 & 1.228 & M & 98 & & 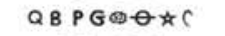 & mixed mudstone, foraminiferal & Wackestone & hemipelagic \\
\hline $823 \mathrm{~B}-12-2-106$ & 105.86 & 1.27 & c & C $B \otimes \otimes$ & $a \star \Delta$ & GPMӨ & dolomitic limestone, bioclastic, foraminiferal & Grainstone & turbidite \\
\hline 823B-12-3-34 & 106.64 & 1.274 & c & $M B D \otimes$ & $\infty)_{\star}$ & $G P Q E G$ & limestone, bioclastic, foraminiferal & Packstone & turbidite \\
\hline $823 \mathrm{~A}-12-6-16$ & 108.46 & 1.282 & & $M B C B \oplus$ & Q & $P G C$ & foraminiferal ooze, bioclastic & Packstone & turbidite \\
\hline $823 \mathrm{~A}-13-2-36$ & 112.16 & 1.299 & Q & $8 \mathrm{C}$ & $A F M G \& B \triangle$ & $F P C \otimes Q$ & mixed sandstone, bioclastic & Grainstone & turbidite in slump \\
\hline 823B-13-2-90 & 115.2 & 1.314 & & C $B \otimes 0$ & $M Q \nless A \Delta \Delta$ & PDOO & dolomitic limestone, bioclastic, foraminiferal & Grainstone, Packstone & turbidite \\
\hline $823 \mathrm{~A}-13-5-47$ & 116.77 & 1.321 & B & $Q C B$ & ॠ(3) & CMPG 8B* & limestone, bioclastic, foraminiferal & Grainstone & turbidite \\
\hline $823 \mathrm{~A}-13-7-16$ & 119.46 & 1.333 & B & $\not \infty$ & $\mathrm{cac} \theta \mathrm{s}$ & GPMEQ & limestone, bioclastic, foraminiferal, quartzose & Grainstone & turbidite? \\
\hline $823 \mathrm{~B}-13-6-30$ & 120.6 & 1.339 & BC & c & $Q \otimes \infty$ & $G P B M$ & limestone, bioclastic & Grainstone & turbidite \\
\hline 823B-14-1-140 & 123.8 & 1.354 & Q & $B C$ & F L $\odot \& \bullet$ & $\approx 0$ & mixed sandstone, bioclastic & Grainstone & turbidite? \\
\hline 823B-14-4-21 & 127.11 & 1.369 & a & $M B \otimes \oplus$ & PC⿱ & $G \triangle B$ & mixed sandstone, bioclastic, quartzose & Grainstone, Wackestone & turbidite \\
\hline 823B-14-5-73 & 129.13 & 1.378 & B & QC & ҰMP $P \otimes 0$ & $\theta \in \theta \theta$ & dolomitic limestone, bioclastic, quartzose & Grainstone, Packstone & turbidite \\
\hline 823B-14-6-69 & 130.59 & 1.385 & & BC & $C Q P \& B M$ & $G B$ & limestone, bioclastic & Grainstone, Packstone & turbidite \\
\hline 823B-15-1-89 & 132.99 & 1.396 & M & (28) & & $Q P B \theta C$ & mixed mudstone, foraminiferal & Wackestone & debris flow \\
\hline 823B-15-6-99 & 140.59 & 1.432 & M\& & B $\circledast$ & ac & $G P \theta B$ & foraminifer chalk, mixed mudstone, bioclastic & Packstone & turbidite \\
\hline 823B-16-2-94 & 144.14 & 1.448 & & $C B \otimes \otimes$ & $Q C \star \star$ & GPMO $\triangle$ & foraminifer chalk, bioclastic & Grainstone & turbidite \\
\hline 823B-16-3-94 & 145.64 & 1.455 & $\$$ & BC & $Q P C \otimes t$ & GMO & foraminifer chalk, bioclastic & Grainstone & turbidite \\
\hline 823B-16-6-68 & 149.88 & 1.475 & & $B \otimes 8$ & $M Q C \star$ & $\mathrm{PCO}$ & foraminifer chalk, bioclastic & Grainstone & turbidite \\
\hline
\end{tabular}




\begin{tabular}{|c|c|c|c|c|c|c|c|c|c|}
\hline Sample & $\begin{array}{c}\text { Depth } \\
\text { (m) }\end{array}$ & $\begin{array}{c}\text { Age } \\
\text { (ma) }\end{array}$ & Abundant & Common & Few & Rare & Rock Types & Carbonate Texture & Depositional Mechanism \\
\hline 823B-18-5-115 & 168.25 & 1.658 & & B & CQDM & $\star \forall P \otimes \theta \theta$ & mixed mudstone, mixed sandstone, bioclastic & Grainstone, Wackestone & turbidite in slump \\
\hline 823B-19-1-90 & 171.7 & 1.672 & & $a_{B} C$ & $\&$ & $M G P D O \otimes \theta A$ & mixed sandstone, bioclastic, quartzose & Grainstone & turbidite \\
\hline 823B-19-6-140 & 179.7 & 1.703 & & $Q B C$ & MCst & $G P \oplus \otimes B$ & mixed sandstone, bioclastic, quartzose & Grainstone & turbidite \\
\hline $823 \mathrm{~B}-20-1-148$ & 181.98 & 1.712 & & $B \&$ & $C Q G M \otimes C *$ & $P D O A$ & foraminifer chalk, bioclastic & Grainstone & turbidite \\
\hline $823 \mathrm{~B}-20-4-125$ & 186.25 & 1.728 & M & $\&$ & (3) & $B C Q P G A \theta \Leftrightarrow \triangle$ & mixed mudstone, foraminiferal & Wackestone & hemipelagic \\
\hline $823 \mathrm{~B}-21-1-108$ & 191.28 & 1.748 & & QBC & $P \&$ & $G \div \otimes$ & mixed sandstone, bioclastic & Grainstone & turbidite \\
\hline $823 \mathrm{~B}-21-5-87$ & 197.07 & 1.771 & $\&$ & $c \otimes$ & $B P C M$ & $Q G Q \theta B$ & foraminifer chalk & Grainstone & turbidite \\
\hline 823B-22-2-109 & 202.39 & 1.791 & B & $C \&$ & 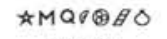 & $F \in C \theta \infty$ & foraminifer chalk, bioclastic, foraminiferal & Grainstone, Packstone & turbidite \\
\hline 823B-22-4-99 & 205.29 & 1.821 & $\&$ & M\% & $a c \theta$ & $P G$ & foraminifer chalk & Packstone & turbidite \\
\hline 823B-22-6-47 & 207.77 & 1.889 & (28) & BMC & CQ১* & PQOE & foraminifer chalk, bioclastic & Packstone & turbidite \\
\hline $823 \mathrm{~B}-22-6-57$ & 207.87 & 1.892 & M & (98) & & $B C G Q A \theta * 0$ & mixed mudstone, foraminiferal & Wackestone & turbidite? \\
\hline 823B-22-6-118 & 208.48 & 1.909 & M & 88 & $\theta$ & B $\diamond$ & mixed mudstone, foraminiferal & Wackestone & debris flow \\
\hline 823B-23-1-80 & 209.9 & 1.948 & $B \&$ & $M C \otimes$ & $C Q P \theta \Delta *$ & $G \theta$ & foraminifer chalk, bioclastic & Packstone & turbidite \\
\hline $823 B-23-2-48$ & 211.08 & 1.98 & $B \&$ & $M Q \otimes C$ & 女CBO & $P G \theta$ & foraminifer chalk, bioclastic, quartzose & Packstone & turbidite \\
\hline 823B-23-3-29 & 212.39 & 2.016 & (8) & BM & $\star a<\theta \Delta$ & GPEO & foraminifer chalk, bioclastic & Packstone & turbidite \\
\hline 823B-23-4-47 & 214.07 & 2.063 & M & (8) & & $B Q G C \theta A C$ & mixed mudstone, foraminiferal & Wackestone & debris flow \\
\hline 823B-23-6-128 & 217.88 & 2.167 & $\&$ & $M \otimes$ & $a_{B} C$ & $G P \theta C$ & foraminifer chalk, bioclastic & Packstone & turbidite \\
\hline 823B-24-1-113 & 219.83 & 2.221 & M & & 88 & $Q P \theta C$ & mixed mudstone, foraminiferal & Wackestone & hemipelagic \\
\hline 823B-24-4-108 & 224.28 & 2.308 & $\&$ & & $C B Q \otimes C M$ & $G P \theta x$ & foraminifer chalk, bioclastic & Packstone & turbidite \\
\hline $823 \mathrm{~B}-25-3-45$ & 231.45 & 2.375 & B & MaC $8 \theta$ & $c \star \Delta$ & $\odot G P D O \theta \theta$ & limestone, foraminifer chalk, bioclastic, quartzose & Grainstone, Packstone & turbidite \\
\hline $823 \mathrm{~B}-25-4-36$ & 232.86 & 2.388 & & $M B C B \Theta$ & $Q C \star$ & $G P \Leftrightarrow \theta$ & foraminifer chalk, bioclastic & Packstone & turbidite \\
\hline $823 B-25-5-119$ & 235.19 & 2.41 & & $B Q M B(8)$ & $c \cos$ & $\mathbb{H} *$ & calcareous chalk, mixed sandstone, bioclastic, quart: & Grainstone, Packstone & turbidite \\
\hline $823 B-25-6-126$ & 236.76 & 2.433 & & Q & $B P C B C$ & $M \odot G \dot{A} \otimes \theta$ & mixed sandstone, bioclastic, quartzose & Grainstone & turbidite \\
\hline 823B-26-3-25 & 240.95 & 2.525 & $\&$ & M & a & $B C P G \theta+C$ & foraminifer chalk & Packstone & turbidite \\
\hline $823 B-26-5-20$ & 243.9 & 2.59 & $\infty$ & $M B \oplus C$ & $Q_{*}$ & $\infty G P \theta A \bullet$ & foraminifer chalk, bioclastic & Packstone & turbidite \\
\hline $823 B-26-5-36$ & 244.06 & 2.594 & B 98 & $M \not C$ & $C B E$ & $G P L \theta Q$ & foraminifer chalk, bioclastic & Grainstone, Packstone & turbidite \\
\hline 823B-26-6-78 & 245.98 & 2.61 & $\infty$ & M & $Q \oplus$ & $G P \theta C$ & foraminifer chalk & Packstone & turbidite \\
\hline 823B-27-7-61 & 256.91 & 2.682 & $\infty$ & (8) & $Q G \theta M$ & PCE & foraminifer chalk & Grainstone, Packstone & turbidite \\
\hline $823 \mathrm{~B}-28-5-8$ & 263.08 & 2.722 & $M 8$ & & $\mathrm{C} \oplus$ & $G P Q \theta A$ & nanno-foram chalk & Packstone, Wackestone & turbidite \\
\hline $823 \mathrm{~B}-28-6-123$ & 265.73 & 2.74 & $\infty$ & M & $P Q \otimes$ & $C B G \theta E C$ & foraminifer chalk & Packstone & turbidite \\
\hline $823 \mathrm{~B}-28-0-22$ & 266.17 & 2.742 & $\$$ & (2) & M & $Q G P B \theta \oplus C$ & foraminifer chalk & Packstone & turbidite \\
\hline 823B-29-4-51 & 271.71 & 2.779 & $\&$ & $M \otimes$ & $a \theta$ & BC & foraminifer chalk & Packstone & turbidite \\
\hline 823B-29-5-25 & 272.95 & 2.787 & $\infty$ & Q.8 & CMO & $G P B A C$ & foraminifer chalk, quartzose & Grainstone & turbidite \\
\hline 823B-29-6-69 & 274.89 & 2.799 & 88 & M & $a \theta$ & $G P \star B$ & foraminifer chalk & Packstone & turbidite \\
\hline $823 B-30-1-95$ & 277.25 & 2.815 & (8) & M & $\theta$ & $B Q G C \star C$ & foraminifer chalk & Packstone & turbidite \\
\hline 823B-30-2-28 & 278.08 & 2.82 & 88 & & QM & $B G P \theta \not \infty O$ & foraminifer chalk & Packstone & turbidite \\
\hline 823B-30-3-89 & 280.19 & 2.834 & $\infty$ & $M \otimes$ & $a \theta$ & $G P B C C$ & foraminifer chalk & Packstone & turbidite \\
\hline $823 B-30-4-86$ & 281.66 & 2.844 & 88 & M & $\theta \theta$ & $Q G P \not \square D B$ & foraminifer chalk & Packstone, Wackestone & turbidite \\
\hline 823B-30-5-15 & 282.45 & 2.849 & M & 88 & $\theta$ & $Q_{B} P G C B C \star$ & nanno-foram chalk & Wackestone & turbidite / pelagic \\
\hline 823B-30-5-79 & 283.09 & 2.853 & 88 & M & $\theta$ & QGBC & foraminifer chalk & Packstone & turbidite \\
\hline 823B-30-6-48 & 284.28 & 2.861 & $M \&$ & (3) & $a_{\theta}$ & $P G$ & mixed mudstone, foraminiferal & Packstone, Wackestone & turbidite / hemipelagic \\
\hline $823 B-31-2-66$ & 288.16 & 2.886 & $\infty$ & M & $Q$ & $c G \theta \theta$ & foraminifer chalk & Packstone & turbidite \\
\hline 823B-31-4-102 & 291.52 & 2.918 & $\infty$ & M & (2) & $Q G \theta C$ & foraminifer chalk & Packstone & turbidite \\
\hline 823B-31-6-128 & 294.78 & 2.962 & 88 & M & $a \theta$ & $B G P C D C$ & foraminifer chalk & Packstone & turbidite \\
\hline $823 B-31-7-107$ & 296.07 & 2.98 & (3) & $M$ & & GPQ: & foraminifer chalk & Packstone & turbidite \\
\hline
\end{tabular}


Appendix B (continued).

\begin{tabular}{|c|c|c|c|c|c|c|c|c|c|}
\hline Sample & $\begin{array}{c}\text { Depth } \\
\text { (m) }\end{array}$ & $\begin{array}{c}\text { Age } \\
(\mathrm{ma})\end{array}$ & Abundant & Common & Few & Rare & Rock Types & Carbonate Texture & Depositional Mechanism \\
\hline 823B-32-3-73 & 299.33 & 3.015 & $M \&$ & (2) & $\theta$ & $P Q$ & foraminifer chalk & Wackestone & turbidite \\
\hline 823B-32-4-47 & 300.57 & 3.026 & $M \otimes$ & (b) & & $p \theta$ & nanno-foram chalk & Wackestone & pelagic \\
\hline 823B-32-4-131 & 301.41 & 3.033 & $\infty$ & M & $Q$ Q & $P G \theta$ & foraminifer chalk & Packstone & turbidite \\
\hline 823B-32-5-82 & 302.42 & 3.041 & $C \&$ & & (2) & $P D$ & dolomitic limestone & Packstone & turbidite \\
\hline 823B-32-6-3 & 303.13 & 3.047 & $\&$ & M & $\theta \circledast$ & $Q P C B$ & foraminifer chalk & Packstone & turbidite \\
\hline 823B-33-1-50 & 305.8 & 3.07 & $M \infty$ & (3) & $\theta$ & 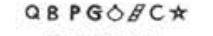 & foraminifer chalk & Packstone & turbidite \\
\hline 823B-33-3-23 & 308.53 & 3.093 & $M \otimes 8$ & & $\theta$ & $C B Q \oplus C \star$ & foraminifer chalk & Packstone & turbidite \\
\hline 823B-33-4-137 & 311.17 & 3.115 & & $Q_{\infty}$ & CM@ & $G P B A C$ & mixed sandstone, foraminiferal & Packstone & turbidite \\
\hline 823B-33-5-94 & 312.24 & 3.124 & $\&$ & M(8) & $a \theta$ & $B G P B \oplus C$ & foraminifer chalk, mixed mudstone, foraminiferal & Packstone, Wackestone & debris flow \\
\hline 823B-34-1-80 & 315.7 & 3.152 & $\$$ & M. & GQO & $\mathrm{P} \theta$ & foraminifer chalk & Packstone & turbidite \\
\hline 823B-34-2-95 & 317.35 & 3.165 & $M \&$ & (3) & a & $\theta \theta$ & mixed mudstone, mixed sandstone, foraminiferal & Packstone, Wackestone & turbidite \\
\hline 823B-35-1-63 & 325.23 & 3.23 & (3) & M & $a \theta$ & $P G$ & foraminifer chalk & Packstone & turbidite \\
\hline 823B-35-1-105 & 325.65 & 3.233 & $\infty$ & M* & a & $G P \theta B$ & foraminifer chalk & Packstone & turbidite \\
\hline 823B-35-2-40 & 326.5 & 3.24 & $\&$ & $M \otimes$ & $Q \theta$ & $P G \otimes$ & foraminifer chalk & Packstone & turbidite \\
\hline 823B-35-3-116 & 328.76 & 3.259 & $\infty$ & M & $a \otimes$ & $P G$ & foraminifer chalk & Packstone & turbidite \\
\hline 823B-36-1-46 & 334.66 & 3.307 & a & $\$$ & $M \otimes$ & $G P \theta L$ & mixed sandstone & Packstone & turbidite \\
\hline 823B-36-2-21 & 335.91 & 3.318 & M & & 88 & GQO & mixed mudstone & Wackestone & slump \\
\hline 823B-36-2-81 & 336.51 & 3.322 & $M \infty$ & $\theta \otimes$ & & $Q \in P A \oplus C$ & mixed mudstone, foraminiferal & Packstone & turbidite \\
\hline $823 \mathrm{~B}-36-4-123$ & 339.93 & 3.351 & M & $\infty$ & $\theta \circledast 3$ & $P Q \odot$ & mixed mudstone, foraminiferal & Wackestone & hemipelagic \\
\hline 823B-36-5-88 & 341.08 & 3.36 & M & 88 & & QBPGCBもலの & mixed mudstone, foraminiferal & Wackestone & turbidite \\
\hline 823B-37-2-70 & 346.1 & 3.401 & M & (28) & & $\theta$ & mixed mudstone, foraminiferal & Wackestone & turbidite / hemipelagic \\
\hline 823B-37-2-142 & 346.82 & 3.407 & M & & (8) & & mixed mudstone & Wackestone & hemipelagic \\
\hline 823B-37-4-25 & 348.65 & 3.422 & M & $\infty$ & $\theta$ & $P G \theta$ & nanno-foram chalk & Wackestone & pelagic \\
\hline 823B-37-7-12 & 353.02 & 3.458 & M & (28) & $\theta$ & $G P Q A \oplus$ & mixed mudstone, foraminiferal & Wackestone & debris flow \\
\hline 823B-37-7-43 & 353.33 & 3.46 & & $\infty$ & $\theta \oplus$ & $Q G P B C B$ & mixed mudstone & Wackestone & debris flow \\
\hline 823B-37-0-15 & 353.4 & 3.461 & M & $\&$ & $\theta \otimes$ & $B Q G A \oplus C$ & mixed mudstone, foraminiferal & Wackestone & debris flow \\
\hline 823B-38-2-60 & 355.5 & 3.478 & M & & (28) & $B Q G \theta A C$ & mixed mudstone & Wackestone & debris flow \\
\hline 823B-38-4-40 & 358.3 & 3.501 & M & & Q & $\theta G \otimes \otimes$ & mixed mudstone & Wackestone & debris flow \\
\hline 823B-38-4-60 & 358.5 & 3.503 & M & & $\theta+\infty$ & $\star B Q \otimes B C$ & mixed mudstone & Wackestone & debris flow \\
\hline 823B-39-1-104 & 364.04 & 3.532 & M & (2) & & $P Q \theta$ & mixed mudstone, foraminiferal & Wackestone & slump \\
\hline 823B-39-3-33 & 366.33 & 3.544 & M & 8 & (2) & $G P Q \theta A$ & mixed mudstone & Wackestone & slump \\
\hline 823B-39-6-48 & 370.98 & 3.566 & $\&$ & $M \otimes$ & $B \theta$ & $Q G P C \star B$ & foraminifer chalk & Packstone & turbidite \\
\hline 823B-39-6-121 & 371.71 & 3.57 & M & (28) & $\theta$ & $Q L G E C B$ & mixed mudstone & Wackestone & debris flow \\
\hline 823B-40-4-95 & 378.15 & 3.601 & M & & & $B C G Q \otimes \infty \otimes \theta$ & mixed mudstone & Wackestone & debris flow \\
\hline $823 \mathrm{~B}-41-4-143$ & 388.33 & 3.65 & (28) & M & $\theta$ & $Q G B A C$ & limestone, foraminiferal & Packstone & turbidite \\
\hline $823 \mathrm{~B}-41-5-60$ & 389 & 3.654 & $\infty$ & (2) & $B Q G M \theta A C$ & $C \star * 0$ & limestone, foraminiferal & Grainstone, Packstone & turbidite \\
\hline $823 \mathrm{~B}-41-6-131$ & 391.21 & 3.664 & M & & $\infty$ & $B Q G(\otimes \theta$ & mixed mudstone & Wackestone & debris flow \\
\hline $823 \mathrm{~B}-42-3-62$ & 395.62 & 3.686 & M & & (98) & $\theta$ & mixed mudstone & Wackestone & slump \\
\hline 823B-42-3-93 & 395.93 & 3.687 & $M \infty$ & (3) & $B E \theta$ & $Q G P C \triangle C \star$ & foraminifer chalk, bioclastic & Packstone, Wackestone & debris flow \\
\hline $823 \mathrm{~B}-42-5-47$ & 398.47 & 3.7 & M & & $\theta \otimes 8$ & $Q \in P B C B$ & mixed mudstone, foraminiferal & Wackestone & slump \\
\hline 823B-42-0-33 & 401.6 & 3.715 & $M \otimes 8$ & & & $Q G P B \theta B C$ & mixed mudstone, foraminiferal & Wackestone & turbidite \\
\hline $823 \mathrm{~B}-43-5-110$ & 408.7 & 3.749 & (2) & & $\theta$ & $B C G Q \otimes B C O$ & calcareous chalk & Packstone & turbidite \\
\hline 823B-43-6-114 & 410.24 & 3.757 & $\infty$ & $M \otimes$ & $B Q G \otimes C C$ & $P F B$ & foraminifer chalk & Packstone & turbidite \\
\hline $823 \mathrm{~B}-44-2-52$ & 413.32 & 3.772 & M & & (38 & $\theta$ & mixed mudstone, foraminiferal & Wackestone & slump \\
\hline 823B-44-4-75 & 416.55 & 3.788 & M & & (28) & $a \theta$ & mixed mudstone & Wackestone & debris flow \\
\hline
\end{tabular}




\begin{tabular}{|c|c|c|c|c|c|c|c|c|c|}
\hline Sample & $\begin{array}{c}\text { Depth } \\
(\mathbf{m})\end{array}$ & $\begin{array}{r}\text { Age } \\
\text { (ma) }\end{array}$ & Abundant & Common & Few & Rare & Rock Types & Carbonate Texture & Depositional Mechanism \\
\hline $823 \mathrm{~B}-46-2-80$ & 432.9 & 3.867 & M & & 88 & $Q L \theta \otimes$ & mixed mudstone & Wackestone & debris flow \\
\hline $823 \mathrm{~B}-46-4-10$ & 435.2 & 3.878 & M & & 88 & $a_{\theta}$ & mixed mudstone & Wackestone & debris flow \\
\hline 823B-47-2-75 & 442.55 & 3.882 & M & & $Q \otimes \infty$ & $\theta$ & foraminifer chalk & Wackestone & slump \\
\hline 823B-47-4-102 & 445.82 & 3.883 & (8) & M & $\theta$ & $G P L E Q$ & foraminifer chalk & Packstone & turbidite in slump \\
\hline 823B-47-6-28 & 448.08 & 3.884 & $M \otimes$ & (3) & $\theta$ & $Q G P B C B$ & foraminifer chalk & Packstone & turbidite in slump \\
\hline $823 \mathrm{~B}-48-2-28$ & 451.68 & 3.886 & $M \otimes$ & (2) & & $Q \in P B \theta A \not$ & mixed mudstone, foraminiferal & Packstone & turbidite \\
\hline $823 B-48-4-46$ & 454.86 & 3.887 & MB & (3) & & QBPGB日 & foraminifer chalk & Packstone & turbidite \\
\hline 823B-49-1-79 & 460.39 & 3.889 & $M \otimes$ & () & $\theta$ & $G Q$ & foraminifer chalk & Packstone & turbidite \\
\hline 823B-49-2-34 & 461.44 & 3.889 & $\&$ & $M \otimes$ & $\theta$ & ৫Q⿻ & foraminifer chalk & Packstone & turbidite \\
\hline 823B-49-3-18 & 462.78 & 3.89 & $M \otimes$ & (2) & & $G P \theta Q$ & foraminifer chalk & Packstone & turbidite \\
\hline 823B-49-5-72 & 466.32 & 3.891 & $\infty$ & M & $G Q$ & $L P \otimes \theta$ & foraminifer chalk & Packstone & turbidite \\
\hline 823B-49-6-89 & 467.99 & 3.892 & $M \otimes$ & & (8) & $G P Q \theta$ & foraminifer chalk & Packstone & turbidite \\
\hline $823 \mathrm{~B}-50-1-26$ & 469.46 & 3.892 & (8) & M & $\theta_{\theta}$ & QPBEC & foraminifer chalk & Packstone & turbidite \\
\hline 823B-50-1-58 & 469.78 & 3.892 & M & (4) & $\theta$ & $a \infty$ & mixed mudstone & Wackestone & hemipelagic \\
\hline 823B-50-2-146 & 472.16 & 3.893 & $M \otimes \infty$ & & $\theta$ & LG PLDO๑Q & foraminifer chalk & Packstone & turbidite \\
\hline 823B-50-3-102 & 473.22 & 3.893 & $M \infty$ & & $Q(2)$ & $G \theta$ & foraminifer chalk & Packstone & turbidite \\
\hline 823B-52-4-77 & 493.07 & 3.937 & $\infty$ & M & $Q$ (⿻) & GPӨの & foraminifer chalk & Packstone & turbidite \\
\hline $823 \mathrm{~B}-52-5-62$ & 494.42 & 3.952 & M & & 98 & GQ⿻ & mixed mudstone & Wackestone & slump \\
\hline 823B-53-1-129 & 498.79 & 3.998 & $M \otimes$ & & 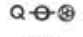 & & foraminifer chalk, mixed mudstone, foraminiferal & Packstone, Wackestone & turbidite \\
\hline 823B-53-2-70 & 499.7 & 4.008 & $\infty$ & $M \oplus$ & GQ & $C \star L B A \theta C \theta$ & foraminifer chalk & Packstone & turbidite \\
\hline 823B-53-4-38 & 502.38 & 4.036 & M & $\infty$ & $\theta \otimes$ & $P G Q$ & mixed mudstone, foraminiferal & Wackestone & slump \\
\hline 823B-54-1-80 & 507.9 & 4.094 & $\infty$ & $M \otimes$ & GQQ & $\mathrm{P} E$ & foraminifer chalk & Packstone & turbidite \\
\hline 823B-54-4-129 & 512.89 & 4.147 & $M \&$ & 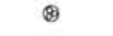 & & $L G \theta a$ & mixed mudstone, foraminiferal & Wackestone & hemipelagic in slump \\
\hline $823 \mathrm{~B}-54-5-126$ & 514.36 & 4.163 & $\$$ & M & $\theta$ (8) & $G P Q A C$ & foraminifer chalk & Packstone, Wackestone & turbidite / hemipelagic \\
\hline 823B-55-3-41 & 520.21 & 4.225 & M & $\$$ & $\theta \otimes$ & $P Q$ & mixed mudstone, foraminiferal & Wackestone & debris flow \\
\hline $823 \mathrm{~B}-55-5-22$ & 523.02 & 4.246 & 88 & & Me & $Q G P \star C B$ & foraminifer chalk & Packstone & turbidite \\
\hline 823B-55-6-36 & 524.66 & 4.253 & $M \otimes$ & (8) & $\theta$ & $G P Q B C$ & foraminifer chalk, mixed mudstone & Packstone, Wackestone & turbidite \\
\hline 823B-55-7-14 & 525.94 & 4.259 & $M \otimes 8$ & & $\theta$ & $P G Q$ & foraminifer chalk & Wackestone & turbidite \\
\hline 823B-55-0-13 & 526.2 & 4.26 & $\infty$ & $M \otimes$ & & $G P \theta Q$ & foraminifer chalk & Packstone & turbidite \\
\hline 823B-56-1-127 & 527.67 & 4.267 & M & & $\theta+8$ & $P Q C$ & mixed mudstone & Wackestone & debris flow \\
\hline 823B-56-4-12 & 531.02 & 4.282 & M & (2) & $\theta$ & a & mixed mudstone, foraminiferal & Wackestone & slump \\
\hline 823B-56-4-137 & 532.27 & 4.287 & M & (28) & $Q_{\theta}$ & & mixed mudstone, foraminiferal & Wackestone & hemipelagic / slump \\
\hline 823B-57-1-40 & 536.1 & 4.304 & (2) & $\theta$ & M & $Q G P B \oplus C$ & foraminifer chalk & Packstone & turbidite \\
\hline 823B-57-1-117 & 536.87 & 4.308 & $8 \infty$ & M & a & BGPӨ®女 & foraminifer chalk & Packstone, Wackestone & turbidite \\
\hline 823B-57-2-88 & 538.08 & 4.313 & (28) & M & $c \theta$ & $G P Q A \oplus$ & foraminifer chalk & Grainstone, Wackestone & turbidite \\
\hline 823B-57-3-130 & 540 & 4.322 & M & (2) & $\theta$ & c & mixed mudstone, foraminiferal & Wackestone & hemipelagic \\
\hline 823B-57-5-9 & 541.79 & 4.33 & $M \otimes 8$ & & $a_{\theta}$ & $L G P \star C B$ & foraminifer chalk, nannofossil chalk, mixed mudstol & Packstone, Wackestone & turbidite \\
\hline 823B-57-6-33 & 543.53 & 4.338 & (2) & M & GQ & $B P C \theta$ औ & foraminifer chalk, nannofossil chalk & Packstone, Wackestone & turbidite \\
\hline $823 \mathrm{~B}-58-1-10$ & 545.5 & 4.347 & $M \otimes 8$ & & $\theta$ & $P G Q$ & foraminifer chalk, mixed mudstone & Packstone, Wackestone & debris flow \\
\hline $823 \mathrm{~B}-58-4-32$ & 550.22 & 4.368 & M & (8) & $\theta$ & a & mixed mudstone, foraminiferal & Wackestone & slump \\
\hline 823B-58-4-32 & 550.22 & 4.368 & M & $\$ 8$ & $\theta$ & a & mixed mudstone, foraminiferal & Wackestone & slump \\
\hline 823B-58-5-70 & 552.1 & 4.376 & M & 88 & $\theta$ & $P Q$ & nanno-foram chalk, mixed mudstone, foraminiferal & Wackestone & slump \\
\hline 823B-59-1-82 & 555.82 & 4.393 & M & 88 & & Ba & mixed mudstone, foraminiferal & Wackestone & hemipelagic \\
\hline 823B-59-2-47 & 556.97 & 4.398 & $M \infty$ & & Q(8) & $B \in P \theta C C$ & foraminifer chalk, mixed mudstone & Packstone, Wackestone & turbidite \\
\hline $823 \mathrm{~B}-59-4-3$ & 559.53 & 4.409 & $M \&$ & $\theta+\frac{1}{0}$ & & $B Q P B \oplus C$ & foraminifer chalk, mixed mudstone, foraminiferal & Packstone, Wackestone & slump \\
\hline
\end{tabular}




\begin{tabular}{|c|c|c|c|c|c|c|c|c|c|}
\hline Sample & $\begin{array}{c}\text { Depth } \\
\text { (m) }\end{array}$ & $\begin{array}{c}\text { Age } \\
(\mathrm{ma})\end{array}$ & Abundant & Common & Few & Rare & Rock Types & Carbonate Texture & Depositional Mechanism \\
\hline 823B-61-2-67 & 576.47 & 4.485 & M & & $8 \infty$ & $Q P C \theta A$ & mixed mudstone, foraminiferal & Wackestone & slump \\
\hline $823 \mathrm{~B}-61-7-22$ & 583.52 & 4.517 & $M \&$ & (2) & & $Q G P \theta C B$ & mixed mudstone, foraminiferal & Wackestone & hemipelagic \\
\hline 823B-62-2-12 & 585.52 & 4.526 & (3) & & QMO & PC & foraminifer chalk & Packstone & turbidite \\
\hline $823 \mathrm{~B}-62-4-70$ & 589.1 & 4.542 & $\&$ & Mө由 & GQC & $L \oplus \theta$ & foraminifer chalk, mixed mudstone, foraminiferal & Grainstone, Wackestone & turbidite \\
\hline 823B-62-5-43 & 590.33 & 4.547 & (28) & M & $\theta$ & $Q G P B \otimes C \not$ & foraminifer chalk & Packstone & turbidite \\
\hline 823B-62-6-20 & 591.6 & 4.553 & $\infty$ & (2) & Me & $F \in P Q \nless C B$ & foraminifer chalk & Packstone & turbidite \\
\hline 823B-62-6-121 & 592.61 & 4.558 & $\infty$ & M & $a \otimes$ & $G P \theta C$ & foraminifer chalk & Packstone & turbidite \\
\hline 823B-62-7-11 & 593.01 & 4.559 & $\&$ & $M \oplus$ & $Q \theta$ & $\infty C B B \otimes C$ & foraminifer chalk & Packstone & turbidite \\
\hline $823 \mathrm{~B}-63-1-2$ & 593.62 & 4.562 & $\infty$ & $M \theta \oplus$ & a & $B C P G \oplus A \neq C$ & foraminifer chalk & Packstone, Wackestone & turbidite \\
\hline 823B-63-2-12 & 595.1 & 4.575 & (98) & & QMO & $P C D O$ & foraminifer chalk & Packstone & turbidite \\
\hline 823B-64-4-20 & 607.9 & 4.688 & 88 & M & $P C \theta$ & Gळ & foraminifer chalk & Packstone & turbidite \\
\hline 823B-64-5-32 & 609.52 & 4.712 & $M \infty$ & (2) & & $Q \in P \theta \star B$ & foraminifer chalk & Packstone & turbidite in slump \\
\hline 823B-65-5-109 & 619.89 & 4.866 & MB\& & & $\theta$ & LGPCQL & mixed mudstone, foraminiferal & Wackestone & debris flow \\
\hline 823B-66-1-33 & 622.83 & 4.91 & (18 & c & $a \in B M$ & $\mathrm{~F}$ & foraminifer chalk & Grainstone, Packstone & turbidite \\
\hline 823B-66-1-38 & 622.88 & 4.911 & (8) & $\theta$ & $\mathrm{CME}$ & a & foraminifer chalk & Packstone & turbidite \\
\hline $823 B-66-4-121$ & 628.21 & 4.99 & M & $\theta 38$ & G & c & nanno-foram chalk, mixed mudstone, foraminiferal & Packstone, Wackestone & slump \\
\hline 823B-66-6-106 & 631.06 & 5.033 & 98 & & $Q G C \theta M$ & $\infty B P B C \star$ & foraminifer chalk & Grainstone & turbidite \\
\hline 823B-67-3-81 & 636.01 & 5.081 & $M \oplus 8$ & & GQ & & foraminifer chalk, mixed mudstone & Packstone, Wackestone & turbidite in debris flow \\
\hline $823 \mathrm{~B}-67-5-97$ & 639.17 & 5.103 & M & (38) & & $Q G P B \theta \nless C$ & mixed mudstone, foraminiferal & Wackestone & hemipelagic \\
\hline $823 \mathrm{~B}-69-4-52$ & 655.92 & 5.218 & ac & $\mathbf{G} \infty$ & $B C B$ & $F P M \otimes \oplus$ & limestone, mixed sandstone, foraminiferal & Grainstone & turbidite \\
\hline 823B-69-7-3 & 659.93 & 5.245 & M & (98) & $\theta$ & $G P D Q$ & mixed mudstone, foraminiferal & Wackestone & slump \\
\hline 823B-70-6-63 & 668.73 & 5.306 & M & (8) & & $Q \theta$ & mixed mudstone, foraminiferal & Wackestone & slump \\
\hline 823B-71-1-119 & 671.49 & 5.325 & $M \otimes \infty$ & & $p \theta$ & $a c 0$ & foraminifer chalk, mixed mudstone & Packstone, Wackestone & hemipelagic \\
\hline 823B-71-6-80 & 678.6 & 5.365 & $M \otimes 8$ & c & GQO & $B L P C \# D$ & nanno-foram chalk, mixed sandstone, foraminiferal & Grainstone, Wackestone & turbidite / hemipelagic \\
\hline $823 B-72-1-83$ & 680.73 & 5.374 & as & QM & $G C$ & $B L P \star \theta A \Delta$ & foraminifer chalk, quartzose & Packstone & turbidite \\
\hline 823B-72-2-49 & 681.89 & 5.379 & $M \otimes \infty$ & & $a \theta$ & $G C \Theta$ & foraminifer chalk, mixed mudstone & Packstone & turbidite \\
\hline 823B-72-2-61 & 682.01 & 5.379 & M & 88 & $a \theta$ & $P G$ & mixed mudstone, foraminiferal & Wackestone, Mudstone & debris flow \\
\hline 823B-72-3-44 & 683.34 & 5.385 & M & $C \nabla \otimes \otimes$ & $\theta$ & GPDOQ & mixed mudstone, foraminiferal & Wackestone & debris flow \\
\hline $823 B-72-5-19$ & 686.09 & 5.396 & (28) & aM & $c \theta$ & LGDOFr & foraminifer chalk, quartzose & Packstone & turbidite \\
\hline 823B-73-1-23 & 689.83 & 5.413 & MB & (2) & $\cos \theta-1+1-1+1)$ & $Q G P C \star B$ & nanno-foram chalk & Packstone, Wackestone & hemipelagic / turbidite \\
\hline 823B-73-6-94 & 698.04 & 5.448 & $a_{\infty}$ & 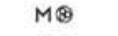 & G BC & LP: $\triangle C$ & mixed mudstone, mixed sandstone, foraminiferal & Packstone, Wackestone & turbidite \\
\hline $823 B-74-1-41$ & 699.71 & 5.456 & M & (8) & $\theta$ & $G P F C Q$ & nanno-foram chalk & Wackestone & slump \\
\hline 823B-74-6-71 & 707.51 & 5.489 & $M \otimes$ & $C \otimes$ & a & $G P B \theta C$ & foraminifer chalk, mixed mudstone, foraminiferal & Packstone, Wackestone & turbidite \\
\hline $823 B-75-2-49$ & 710.89 & 5.504 & 98 & & $G \theta$ & PBC & nanno-foram chalk, mixed mudstone & Packstone, Wackestone & slump \\
\hline $823 B-75-4-28$ & 713.68 & 5.516 & & $M Q 8 \otimes$ & GB $\theta$ & $C P \sharp \triangle C$ & nanno-foram chalk, quartzose & Packstone & turbidite \\
\hline 823B-75-5-49 & 715.39 & 5.523 & & & $a \oplus 8$ & $B \in \theta C$ & mixed mudstone, foraminiferal & Wackestone & slump \\
\hline $823 B-75-6-116$ & 717.56 & 5.533 & $M \otimes \infty$ & & $\theta$ & $P G Q$ & foraminifer chalk, mixed mudstone & Packstone, Wackestone & slump \\
\hline 823B-76-3-30 & 721.9 & 5.551 & ఉ8 & $\theta$ & $B Q G C M C$ & 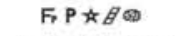 & foraminifer chalk & Grainstone, Packstone & turbidite \\
\hline 823B-76-7-44 & 728.04 & 5.578 & a & $M C \infty B$ & G & $\star B P C \theta A \oplus$ & mixed sandstone, foraminiferal & Packstone & turbidite \\
\hline 823B-77-2-142 & 731.12 & 5.591 & M & $Q_{8}$ & $\theta$-8) & LGPBC $\not C$ & mixed mudstone, foraminiferal, quartzose & Packstone, Wackestone & turbidite \\
\hline 823B-77-3-22 & 731.42 & 5.592 & M & (28) & $\theta$ & GQC & mixed mudstone, foraminiferal & Wackestone & debris flow \\
\hline $823 B-77-6-13$ & 735.83 & 5.624 & M & 98 & $\theta$ & $Q G P C C B$ & mixed mudstone, foraminiferal & Wackestone & slump \\
\hline $823 \mathrm{~B}-78-1-24$ & 738.14 & 5.644 & M & (28) & $\theta$ & $G P C Q$ & mixed mudstone, foraminiferal & Wackestone & slump \\
\hline 823B-78-4-69 & 743.09 & 5.687 & M & (28) & & $Q G P B \theta \div C$ & mixed mudstone, foraminiferal & Wackestone & hemipelagic \\
\hline 823B-79-1-81 & 748.41 & 5.733 & M & $\infty$ & $\cos \theta$ & $G P C B$ & mixed mudstone, foraminiferal & Wackestone & slump \\
\hline
\end{tabular}




\begin{tabular}{|c|c|c|c|c|c|c|c|c|c|}
\hline Sample & $\begin{array}{l}\text { Depth } \\
\text { (m) }\end{array}$ & $\begin{array}{c}\text { Age } \\
\text { (ma) }\end{array}$ & Abundant & Common & Few & Rare & Rock Types & Carbonate Texture & Depositional Mechanism \\
\hline 823B-80-5-98 & 764.28 & 5.871 & M & $Q_{\infty}$ & $G C \otimes$ & LPBC & nanno-foram chalk, quartzose & Packstone, Wackestone & slump \\
\hline 823B-81-4-30 & 771.8 & 5.948 & M & $\infty$ & $\theta \oplus$ & $G P Q D O C$ & nanno-foram chalk & Wackestone & slump \\
\hline 823B-81-0-12 & 775.33 & 5.988 & M & $\infty$ & $Q \otimes$ & $P G \theta$ & mixed mudstone, foraminiferal & Wackestone & slump \\
\hline 823B-82-3-37 & 780.07 & 6.043 & M & (3) & a & $B \in P \theta C C$ & mixed mudstone, foraminiferal & Wackestone & turbidite / hemipelagic \\
\hline 823B-82-4-133 & 782.53 & 6.071 & M & 88 & $a c \theta$ & $P G$ & foraminifer chalk, mixed mudstone, foraminiferal & Packstone, Wackestone & debris flow \\
\hline $823 \mathrm{C}-1-1-9$ & 784.09 & 6.089 & (7) & M & $a c \theta$ & $P G B$ & foraminifer chalk & Packstone & turbidite \\
\hline $823 \mathrm{C}-1-3-67$ & 787.67 & 6.13 & M & 38 & $\theta$ & $P Q C$ & nanno-foram chalk & Wackestone & slump \\
\hline $823 \mathrm{~B}-83-3-125$ & 790.65 & 6.165 & M & 88 & $\theta$ & $Q C$ & mixed mudstone, foraminiferal & Wackestone & debris flow \\
\hline $823 \mathrm{C}-2-1-77$ & 794.37 & 6.207 & (28) & M & $Q \in \theta C$ & $L P L A B$ & foraminifer chalk & Packstone & turbidite \\
\hline $823 C-2-1-135$ & 794.95 & 6.214 & Q & CGMB@ & PLF, & $\not B \theta C$ & mixed sandstone, foraminiferal & Packstone & turbidite \\
\hline $823 \mathrm{C}-2-2-73$ & 795.83 & 6.224 & & MQळ० & & GPCL & mixed sandstone, foraminiferal & Packstone & turbidite \\
\hline 823B-84-1-34 & 796.04 & 6.227 & $M \otimes 8$ & a & & GPLDOC & foraminifer chalk, quartzose & Packstone & turbidite \\
\hline $823 \mathrm{C}-2-4-110$ & 799.2 & 6.263 & M & 88 & Q & $P G C$ & mixed mudstone & Wackestone & turbidite \\
\hline $823 \mathrm{C}-3-1-147$ & 804.37 & 6.323 & (A) & M & $c \theta$ & LQLIPG®BCB & foraminifer chalk & Packstone & turbidite \\
\hline $823 \mathrm{C}-3-4-88$ & 808.28 & 6.368 & (28) & QM & $c \theta$ & LGPLCDB & foraminifer chalk, quartzose & Packstone & turbidite \\
\hline $823 \mathrm{C}-3-0-12$ & 808.93 & 6.375 & M\& & (2) & $\odot c \theta$ & $Q G P B C B$ & mixed mudstone, foraminiferal & Packstone & turbidite \\
\hline $823 C-4-2-107$ & 815.17 & 6.447 & $M \otimes 8$ & & $G C \theta$ & $B Q P B C \star$ & mixed mudstone, foraminiferal & Packstone, Wackestone & debris flow \\
\hline $823 C-4-3-87$ & 816.47 & 6.462 & $M \otimes 8$ & c & $\odot$ & $B P C \theta B$ & foraminifer chalk & Packstone & turbidite \\
\hline $823 C-4-4-115$ & 818.25 & 6.482 & (38) & M & $c \theta$ & $\Sigma G C B$ & foraminifer chalk & Packstone & turbidite \\
\hline $823 \mathrm{C}-5-1-54$ & 822.84 & 6.535 & M & (98) & $\theta$ & $G P C Q$ & nanno-foram chalk & Wackestone & slump \\
\hline $823 C-5-6-43$ & 830.23 & 6.62 & $M \otimes$ & (2) & $a c \theta$ & GPBC & mixed mudstone, foraminiferal & Wackestone & slump \\
\hline $823 \mathrm{C}-6-1-1$ & 832.01 & 6.641 & $M \otimes \infty$ & & $B Q \theta C$ & $\triangle G A F B C$ & foraminifer chalk & Packstone, Wackestone & turbidite \\
\hline $823 \mathrm{C}-6-2-33$ & 833.83 & 6.662 & M.88 & & $B C \theta$ & $C A H E$ & foraminifer chalk & Packstone & turbidite \\
\hline $823 C-7-2-22$ & 843.42 & 6.772 & 80 & M & $B Q \theta C$ & $G \star \Delta$ & foraminifer chalk & Packstone & turbidite \\
\hline $823 \mathrm{C}-7-4-74$ & 846.94 & 6.813 & M & 88 & $a_{\theta}$ & $G C$ & mixed mudstone, foraminiferal & Wackestone, Floatstone & debris flow \\
\hline $823 C-7-6-51$ & 849.71 & 6.844 & 88 & $\mathrm{BC}$ & $M B G \theta \oplus C$ & 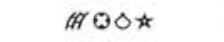 & intraclastic conglomerate, foraminiferal & Grainstone, Packstone, Ruc & t turbidite \\
\hline $823 \mathrm{C}-7-6-56$ & 849.76 & 6.845 & $M C D \otimes$ & 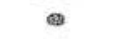 & $B Q G C \theta B D$ & 0 & intraclastic conglomerate & Floatstone & turbidite \\
\hline $823 \mathrm{C}-7-6-69$ & 849.89 & 6.846 & (28) & M & $c \theta$ & $Q G P B A C D$ & foraminifer chalk & Packstone & turbidite \\
\hline $823 \mathrm{C}-8-1-42$ & 851.82 & 6.869 & $M \otimes$ & (2) & a & $P G \theta$ & foraminifer chalk, nanno-foram chalk & Packstone, Wackestone & debris flow \\
\hline $823 \mathrm{C}-8-1-133$ & 852.73 & 6.879 & $M \otimes 8$ & & a & $G P \theta C$ & foraminifer chalk, quartzose & Packstone & turbidite \\
\hline $823 C-8-1-147$ & 852.87 & 6.881 & $M \otimes \infty$ & & $Q C$ & BGPTӨAФ & foraminifer chalk & Packstone & turbidite \\
\hline $823 C-9-1-140$ & 862.5 & 6.992 & 280 & M & & $B Q G C B \oplus C$ & foraminifer chalk & Packstone & turbidite \\
\hline $823 \mathrm{C}-9-2-85$ & 863.45 & 7.003 & M & (8) & a & $C G \theta \theta$ & foraminifer chalk, nanno-foram chalk & Packstone, Wackestone & turbidite \\
\hline $823 \mathrm{C}-9-2-115$ & 863.75 & 7.006 & $M \oplus \infty$ & & & $a \theta$ & foraminifer chalk & Packstone & turbidite \\
\hline $823 C-9-3-59$ & 864.69 & 7.017 & M & & (28) & LQ⿻ & mixed mudstone, foraminiferal & Wackestone & debris flow \\
\hline $823 C-9-3-112$ & 865.22 & 7.023 & $M \oplus 8$ & & $a c \theta$ & $B G \oplus C$ & foraminifer chalk & Packstone & hemipelagic? \\
\hline $823 \mathrm{C}-9-3-127$ & 865.37 & 7.025 & $M \otimes \infty$ & & & $B Q G \theta \otimes Q$ & nanno-foram chalk & Packstone, Wackestone & hemipelagic? \\
\hline $823 C-9-5-64$ & 867.74 & 7.052 & $M \otimes 8$ & & a & $G P \theta E$ & foraminifer chalk, mixed mudstone & Packstone, Wackestone & turbidite \\
\hline $823 C-9-5-89$ & 867.99 & 7.055 & M & (28) & & $\Varangle B A \oplus$ & mixed mudstone, foraminiferal & Wackestone & debris flow \\
\hline $823 C-9-5-142$ & 868.52 & 7.061 & M & 28 & a & $G \theta$ & foraminifer chalk & Packstone & turbidite \\
\hline $823 \mathrm{C}-9-5-145$ & 868.55 & 7.061 & (98) & M & a & DOBFC $A B O$ & foraminifer chalk, quartzose & Packstone & turbidite \\
\hline $823 C-9-6-94$ & 869.54 & 7.073 & M & (28) & $\theta$ & $B Q C D$ & foraminifer chalk, nannofossil chalk & Packstone, Mudstone & turbidite / hemipelagic \\
\hline $823 \mathrm{C}-9-0-12$ & 869.79 & 7.076 & M & (8) & $\theta$ & a & nanno-foram chalk, mixed mudstone & Wackestone & turbidite \\
\hline $823 \mathrm{C}-10-1-19$ & 870.99 & 7.089 & M & 188 & & $C B Q \theta \bullet$ & nanno-foram chalk, mixed mudstone & Wackestone & debris flow \\
\hline $823 C-10-2-67$ & 872.97 & 7.112 & M & & (8) & Barec & nanno-foram chalk, mixed mudstone & Wackestone & debris flow \\
\hline
\end{tabular}




\begin{tabular}{|c|c|c|c|c|c|c|c|c|c|}
\hline Sample & $\begin{array}{c}\text { Depth } \\
(\mathrm{m})\end{array}$ & $\begin{array}{c}\text { Age } \\
\text { (ma) }\end{array}$ & Abundant & Common & Few & Rare & Rock Types & Carbonate Texture & Depositional Mechanism \\
\hline $823 \mathrm{C}-10-5-10$ & 876.9 & 7.157 & $Q \otimes 8$ & M & GC & $P B \theta$ & mixed sandstone & Packstone & turbidite \\
\hline $823 \mathrm{C}-10-5-42$ & 877.22 & 7.161 & (8) & QM & GC & $P A \theta$ & foraminifer chalk, mixed sandstone & Packstone & turbidite \\
\hline $823 C-10-5-60$ & 877.4 & 7.163 & (2) & aCM & G & $C B P \theta B \triangle$ & foraminifer chalk & Packstone & turbidite \\
\hline $823 \mathrm{C}-11-1-10$ & 880.5 & 7.199 & (2) & & & $\odot a_{x} \theta$ & foraminifer chalk & Packstone & turbidite \\
\hline $823 \mathrm{C}-11-1-116$ & 881.56 & 7.211 & $M \otimes 8$ & & QB & $C G P D O O C \star$ & foraminifer chalk, nanno-foram chalk & Packstone, Wackestone & turbidite \\
\hline $823 \mathrm{C}-11-2-33$ & 882.23 & 7.219 & $M \otimes \infty$ & a & PC & $G B \theta$ & foraminifer chalk, nanno-foram chalk, quartzose & Packstone, Wackestone & turbidite \\
\hline $823 \mathrm{C}-11-2-47$ & 882.37 & 7.22 & (2) & M & a & G১৫ & intraclastic conglomerate & Floatstone & debris flow \\
\hline $823 \mathrm{C}-11-3-16$ & 883.56 & 7.234 & $M \otimes$ & $\&$ & $a \theta$ & $B F G B C \hbar$ & foraminifer chalk, nanno-foram chalk, mixed mudst & Wackestone & debris flow \\
\hline $823 \mathrm{C}-11-5-6$ & 886.46 & 7.267 & $M \otimes \infty$ & & $\Sigma$ & $C B G \div \theta A \oplus$ & intraclastic conglomerate & Floatstone & debris flow \\
\hline $823 \mathrm{C}-11-5-38$ & 886.78 & 7.271 & 88 & & a & 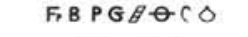 & foraminifer chalk, nanno-foram chalk, quartzose & Packstone & turbidite / hemipelagic \\
\hline $823 C-11-6-13$ & 888.03 & 7.285 & (28) & M & $a c$ & GPDOF & foraminifer chalk & Packstone, Wackestone & turbidite \\
\hline $823 \mathrm{C}-12-1-105$ & 891.15 & 7.321 & M & (28) & $\odot \theta$ & $B Q L \infty O B C \star$ & nanno-foram chalk, mixed mudstone, foraminiferal & Wackestone & slump \\
\hline $823 \mathrm{C}-12-2-98$ & 892.58 & 7.338 & $a_{\infty}$ & $M \otimes$ & $A$ & GPF,CB & foraminifer chalk, mixed sandstone & Packstone & turbidite \\
\hline $823 \mathrm{C}-12-3-44$ & 893.54 & 7.349 & M\&8 & & B & $* C \nabla B F \theta B C$ & nanno-foram chalk, bioclastic & Wackestone & debris flow \\
\hline $823 \mathrm{C}-12-3-120$ & 894.3 & 7.358 & $M \otimes 8$ & & & $Q P C \theta \oplus$ & foraminifer chalk & Packstone, Wackestone & pelagic \\
\hline $823 \mathrm{C}-12-5-146$ & 897.56 & 7.395 & (8) & M & $G \oplus$ & $\infty$ D P $\theta$ B & foraminifer chalk & Packstone & turbidite \\
\hline $823 \mathrm{C}-12-6-91$ & 898.51 & 7.406 & $M \&$ & $B \otimes$ & $A B \square \theta B$ & $\not O D O \oplus B C$ & foraminifer chalk, nanno-foram chalk, bioclastic & Wackestone & debris flow \\
\hline $823 C-12-0-9$ & 899.16 & 7.414 & M & (98) & $\theta \square H A C$ & बB & mixed mudstone, intraclastic conglomerate, bioclast & Wackestone, Floatstone & debris flow \\
\hline $823 C-13-1-74$ & 900.44 & 7.428 & M & & (ब8 & $c \theta$ & nanno-foram chalk, mixed mudstone, foraminiferal & Wackestone & slump \\
\hline $823 \mathrm{C}-13-2-30$ & 901.5 & 7.441 & (38) & & $C B \theta M$ & $\triangle \odot Q P G A B \oplus B \triangle C B$ & foraminifer chalk & Packstone & turbidite \\
\hline $823 \mathrm{C}-13-3-95$ & 903.65 & 7.465 & M & (8) & $\theta$ & $B \odot A F B^{A}$ & nanno-foram chalk & Wackestone & turbidite / pelagic \\
\hline $823 \mathrm{C}-13-4-0$ & 904.2 & 7.472 & MQB & $B C \otimes$ & 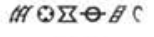 & $\star Q G \oplus \Delta \theta$ & nanno-foram chalk, bioclastic & Wackestone, Floatstone & debris flow \\
\hline $823 \mathrm{C}-13-4-61$ & 904.81 & 7.479 & M & (28) & $c \theta$ & $Q G / B$ & nanno-foram chalk, mixed mudstone, foraminiferal & Wackestone & debris flow \\
\hline $823 \mathrm{C}-13-7-102$ & 909.72 & 7.535 & M & 88 & $\theta$ & $Q P C B D$ & foraminifer chalk, nanno-foram chalk & Packstone, Wackestone & slump \\
\hline $823 \mathrm{C}-14-1-132$ & 910.72 & 7.547 & (38) & M & $a \theta$ & $D B G A F B C C$ & foraminifer chalk & Packstone & debris flow \\
\hline $823 \mathrm{C}-14-2-7$ & 910.97 & 7.55 & M & & (B) & $a \theta$ & mixed mudstone & Wackestone & debris flow \\
\hline $823 \mathrm{C}-14-3-71$ & 913.11 & 7.574 & (28) & QM & $c \theta$ & $B \in C B O$ & foraminifer chalk, quartzose & Packstone & turbidite \\
\hline $823 \mathrm{C}-14-4-3$ & 913.93 & 7.584 & $M \oplus \infty$ & & c & $Q B P G D O B \theta C \theta$ & foraminifer chalk & Packstone & hemipelagic in slump \\
\hline $823 \mathrm{C}-14-4-136$ & 915.26 & 7.599 & M & (38) & & $\infty$ & nanno-foram chalk & Wackestone & debris flow \\
\hline $823 \mathrm{C}-14-5-65$ & 916.05 & 7.608 & $M \otimes \infty$ & & & $\theta \mathrm{CBC} \theta \theta^{\prime} \oplus$ & nanno-foram chalk, mixed mudstone & Packstone, Wackestone & debris flow / pelagic \\
\hline $823 C-15-1-20$ & 919.3 & 7.645 & $M \otimes 8$ & & & 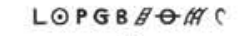 & foraminifer chalk, nanno-foram chalk & Packstone, Wackestone & turbidite \\
\hline $823 \mathrm{C}-15-3-130$ & 923.4 & 7.693 & M & (98) & & $\theta$ & nanno-foram chalk, mixed mudstone & Wackestone & slump \\
\hline $823 \mathrm{C}-15-5-8$ & 925.18 & 7.713 & $M \otimes 8$ & & $\odot \theta$ & $\mathrm{C} B$ & nanno-foram chalk, mixed mudstone & Wackestone & debris flow \\
\hline $823 \mathrm{C}-15-6-24$ & 926.84 & 7.732 & $M \otimes 8$ & & a & $p \theta$ & nanno-foram chalk, mixed mudstone & Wackestone & debris flow \\
\hline $823 \mathrm{C}-15-6-100$ & 927.6 & 7.741 & $M \otimes 8$ & & a & $G P \theta B$ & mixed mudstone, foraminiferal & Wackestone & debris flow \\
\hline $823 \mathrm{C}-16-1-107$ & 929.87 & 7.767 & M & & $\theta \oplus 8$ & $a c$ & mixed mudstone, foraminiferal & Wackestone & slump \\
\hline $823 \mathrm{C}-16-3-26$ & 932.06 & 7.792 & M & (8) & $\odot$ & $Q c \theta$ & nanno-foram chalk, mixed mudstone & Wackestone & slump \\
\hline $823 \mathrm{C}-16-4-46$ & 933.76 & 7.812 & M & (28) & & $a \theta$ & nanno-foram chalk & Wackestone & debris flow \\
\hline $823 C-16-5-49$ & 935.29 & 7.829 & $M \otimes B$ & & & $Q C \theta$ & nanno-foram chalk & Wackestone & slump \\
\hline $823 \mathrm{C}-17-1-94$ & 939.34 & 7.876 & M@8 & & & $a c \theta$ & nanno-foram chalk, mixed mudstone & Wackestone & slump \\
\hline $823 C-17-2-45$ & 940.35 & 7.888 & M & (28) & & $a c \theta$ & foraminifer chalk, mixed mudstone, foraminiferal & Wackestone & slump \\
\hline $823 \mathrm{C}-17-4-37$ & 943.27 & 7.921 & (8) & M & ac & $B \Theta \square G F \oplus B \triangle \star C$ & foraminifer chalk & Packstone & turbidite \\
\hline $823 \mathrm{C}-17-4-50$ & 943.4 & 7.923 & (2) 8 & $\Sigma$ & $M B \oplus A F$ & $\not \otimes \diamond \mathrm{C}$ & intraclastic conglomerate & Rudstone & turbidite \\
\hline $823 \mathrm{C}-17-5-31$ & 944.71 & 7.938 & (28) & & $Q \odot C$ & $F B P G M \triangle A D O C$ & foraminifer chalk & Packstone & turbidite \\
\hline $823 C-17-5-64$ & 945.04 & 7.942 & (2) & & & $\theta$ & nanno-foram chalk & Packstone, Wackestone & pelagic \\
\hline
\end{tabular}




\begin{tabular}{|c|c|c|c|c|c|c|c|c|c|}
\hline Sample & $\begin{array}{c}\text { Depth } \\
\text { (m) }\end{array}$ & $\begin{array}{l}\text { Age } \\
\text { (ma) }\end{array}$ & Abundant & Common & Few & Rare & Rock Types & Carbonate Texture & Depositional Mechanism \\
\hline $823 \mathrm{C}-18-2-12$ & 949.62 & 7.994 & $M \otimes 8$ & Q & $\theta$ & $F, G P B A C C$ & nanno-foram chalk, mixed sandstone & Packstone, Wackestone & turbidite \\
\hline $823 C-18-2-93$ & 950.43 & 8.004 & $M \oplus 8$ & & $\odot Q B B$ & $\mathbb{H G} \mathrm{G} C \circlearrowright$ & foraminifer chalk & Packstone, Wackestone & slump \\
\hline $823 \mathrm{C}-18-3-5$ & 951.05 & 8.011 & $M \otimes 8$ & & $a \theta$ & LBPGC@CD & nanno-foram chalk & Wackestone & slump \\
\hline $823 \mathrm{C}-18-5-80$ & 954.8 & 8.054 & $M \otimes \&$ & Q & & $G P \theta A$ & nanno-foram chalk & Wackestone & slump \\
\hline $823 C-18-6-28$ & 955.78 & 8.065 & $M Q \Delta \otimes$ & & $c \theta$ & $F G P B A \oplus C$ & nanno-foram chalk, mixed sandstone & Packstone, Wackestone & slump \\
\hline $823 C-19-3-47$ & 960.77 & 8.123 & M & (3) & a & $B L P C \theta A C$ & mixed mudstone, foraminiferal & Wackestone & slump \\
\hline $823 \mathrm{C}-19-3-81$ & 961.11 & 8.127 & M & $Q_{\infty}$ & (B) & $B L P \theta B C$ & nanno-foram chalk, mixed mudstone & Wackestone & slump \\
\hline $823 C-19-5-40$ & 963.7 & 8.156 & $M \otimes \&$ & & a & 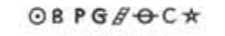 & nanno-foram chalk, mixed mudstone, foraminiferal & Wackestone & slump \\
\hline $823 \mathrm{C}-19-5-95$ & 964.25 & 8.163 & M & 88 & a & $B L C B C$ & mixed mudstone, foraminiferal & Wackestone & slump \\
\hline $823 \mathrm{C}-20-1-72$ & 967.62 & 8.222 & $M \otimes 8$ & & $Q \odot$ & $B C P L \approx B \theta C \oplus$ & mixed mudstone, foraminiferal & Wackestone & turbidite \\
\hline $823 \mathrm{C}-20-1-135$ & 968.25 & 8.299 & (28) & c & a & $G P B \triangle C$ & foraminifer chalk & Grainstone & turbidite \\
\hline $823 \mathrm{C}-20-2-17$ & 968.57 & 8.338 & $a_{\infty}$ & $C B \circledast$ & $M B \triangle C$ & GPFA * & mixed sandstone, foraminiferal & Grainstone & turbidite \\
\hline $823 \mathrm{C}-20-2-51$ & 968.91 & 8.38 & (28) & & & LQPLツ曰B B & intraclastic conglomerate & Floatstone & debris flow \\
\hline $823 \mathrm{C}-20-3-51$ & 970.41 & 8.564 & M & (๑) & $Q_{\infty}$ & $\Sigma L G \triangle \Theta B$ & mixed conglomerate & Floatstone & debris flow \\
\hline $823 C-20-3-65$ & 970.55 & 8.581 & M & Q.5०Q⿻ & $B \oplus B$ & GPZQC & limestone, quartzose & Rudstone & debris flow \\
\hline $823 \mathrm{C}-20-3-90$ & 970.8 & 8.612 & & $M B \otimes \otimes$ & $C \Sigma B \triangle$ & Gळの & intraclastic conglomerate & Floatstone & debris flow \\
\hline $823 \mathrm{C}-20-3-139$ & 971.29 & 8.672 & (28) & GM & $c \theta$ & $B Y P Q \square \otimes B C O$ & mixed sandstone & Grainstone & turbidite \\
\hline $823 \mathrm{C}-20-4-11$ & 971.51 & 8.699 & M & (8) & $Q_{B}$ & $F, G P B \oplus \not A H$ & intraclastic conglomerate & Floatstone & debris flow \\
\hline $823 \mathrm{C}-20-5-48$ & 973.38 & 8.77 & M & $\$ 8$ & $a_{B}$ & GPL $\theta C$ & mixed mudstone, foraminiferal & Wackestone & debris flow \\
\hline $823 \mathrm{C}-20-5-130$ & 974.2 & 8.781 & M & $Q \otimes 8$ & $\mathrm{cc}$ & $\odot B P G B \oplus \triangle \oplus$ & nanno-foram chalk, mixed mudstone, foraminiferal & Wackestone & debris flow \\
\hline $823 \mathrm{C}-20-6-96$ & 975.36 & 8.797 & Q & $M \otimes B$ & $\mathbf{p}$ & $B C G L B \theta D O C$ & foraminifer chalk, mixed sandstone, foraminiferal & Grainstone, Packstone & turbidite \\
\hline $823 \mathrm{C}-20-7-20$ & 976.1 & 8.808 & M & (28) & Q & FBGLCB $B=C$ & mixed mudstone, foraminiferal & Wackestone & debris flow \\
\hline $823 \mathrm{C}-21-1-8$ & 976.68 & 8.816 & $\infty$ & $M B C B \oplus$ & $F \diamond \theta$ & $F, Q P G \cong \$ Q \mathbb{K F}$ & limestone, bioclastic & Packstone, Rudstone & turbidite \\
\hline $823 \mathrm{C}-21-1-92$ & 977.52 & 8.828 & $Q C$ & $B$ GMB@ & $B \theta$ & $\not C$ & nanno-foram chalk, sandstone, quartzose & Grainstone, Wackestone & turbidite / pelagic \\
\hline $823 \mathrm{C}-21-1-127$ & 977.87 & 8.833 & $M \otimes \&$ & & $Q \subset B$ & $B G P D O \theta \oplus C$ & foraminifer chalk & Packstone & slump \\
\hline $823 \mathrm{C}-21-3-21$ & 979.81 & 8.86 & (2) & CM & GQ & $B \searrow P F, B \theta C \otimes$ & foraminifer chalk & Grainstone, Packstone & turbidite \\
\hline $823 \mathrm{C}-21-3-131$ & 980.91 & 8.875 & M & (8) & a & $P G L$ & mixed mudstone, foraminiferal & Wackestone & turbidite \\
\hline $823 \mathrm{C}-21-4-50$ & 981.6 & 8.885 & $M \otimes \&$ & & a & $c \theta$ & foraminifer chalk & Wackestone & turbidite \\
\hline $823 \mathrm{C}-21-6-10$ & 984.2 & 8.921 & (9) & M & $a$ & GPCODO & foraminifer chalk & Packstone & turbidite \\
\hline $823 C-21-6-96$ & 985.06 & 8.933 & (28) & & QM & $C D G B A \theta A F C$ & foraminifer chalk & Packstone & turbidite \\
\hline $823 \mathrm{C}-22-2-80$ & 988.5 & 8.981 & M & $\&$ & $\theta \cdot(3)$ & LPQEC & mixed mudstone, foraminiferal & Wackestone & turbidite \\
\hline $823 C-22-3-53$ & 989.73 & 8.998 & M & & $Q \otimes \infty$ & $L G C \theta B$ & mixed mudstone & Wackestone & debris flow \\
\hline $823 \mathrm{C}-22-3-84$ & 990.04 & 9.015 & 88 & QM & $G \theta$ & $C B \odot A \nless \infty$ & foraminifer chalk, quartzose & Packstone & turbidite \\
\hline $823 C-22-4-41$ & 991.11 & 9.096 & a & $C B \&$ & M & $L G P \oplus A F F$ & mixed sandstone, foraminiferal & Packstone & turbidite \\
\hline $823 \mathrm{C}-22-4-101$ & 991.71 & 9.141 & $\Phi B 8$ & $B M C$ & $a c o$ & LIZPGAf $B \otimes \star 0$ & limestone, bioclastic & Grainstone, Packstone & turbidite \\
\hline $823 \mathrm{C}-22-4-108$ & 991.78 & 9.147 & 88 & c & $B Q C M$ & $P \triangle B$ & foraminifer chalk & Packstone & slump \\
\hline $823 \mathrm{C}-22-4-117$ & 991.87 & 9.153 & M & & $Q \otimes 8$ & $B \odot c \theta c$ & nanno-foram chalk, quartzose & Wackestone & turbidite \\
\hline $823 \mathrm{C}-22-6-5$ & 993.75 & 9.296 & (28) & QCM & $B$ & $F G P B C \star A H$ & foraminifer chalk, nanno-foram chalk & Packstone, Wackestone & turbidite \\
\hline $823 \mathrm{C}-22-6-15$ & 993.85 & 9.304 & Q & Mos & $\circledast G \otimes B$ & $P C A F$ & mixed sandstone, foraminiferal & Packstone & turbidite \\
\hline $823 \mathrm{C}-22-6-128$ & 994.98 & 9.389 & $Q \oplus \infty$ & & $B G C C M$ & $\mathrm{P} \triangle A$ & foraminifer chalk, mixed sandstone & Grainstone, Packstone & turbidite \\
\hline $823 \mathrm{C}-23-1-20$ & 996.1 & 9.474 & (28) & QCM & B & $L F P G \backsim B 10$ & foraminifer chalk, quartzose & Packstone & turbidite \\
\hline $823 C-23-2-73$ & 998.13 & 9.628 & Q & M & $P \otimes 8$ & $F L G \odot \theta B C$ & mixed sandstone, foraminiferal & Grainstone, Packstone & turbidite \\
\hline $823 \mathrm{C}-23-3-28$ & 999.18 & 9.708 & M & Q(8) & & CPAC & mixed mudstone, mixed sandstone, foraminiferal & Packstone, Wackestone & turbidite \\
\hline $823 \mathrm{C}-23-3-62$ & 999.52 & 9.734 & Q & $C \&$ & CMBA@ & $F \in \nabla \nless Q$ & mixed sandstone & Grainstone, Packstone & turbidite \\
\hline $823 \mathrm{C}-23-4-110$ & 1001.5 & 9.884 & M & $Q \oplus 8$ & & $G P L \theta C$ & mixed mudstone & Wackestone & slump \\
\hline
\end{tabular}


Appendix B (continued).

\begin{tabular}{|c|c|c|c|c|c|c|c|c|c|}
\hline Sample & $\begin{array}{c}\text { Depth } \\
\text { (m) }\end{array}$ & $\begin{array}{c}\text { Age } \\
\text { (ma) }\end{array}$ & Abundant & Common & Few & Rare & Rock Types & Carbonate Texture & Depositional Mechanism \\
\hline $823 \mathrm{C}-23-6-14$ & 1003.54 & 10.039 & a & $\mathrm{C} \oplus$ & $A F B \otimes B$ & $F, G P \otimes M \odot$ & mixed sandstone & Grainstone & turbidite \\
\hline $823 \mathrm{C}-23-6-111$ & 1004.51 & 10.112 & a & M & (28) & $C D O L P G B \theta \triangle A B A$ & mixed sandstone & Packstone & turbidite \\
\hline $823 C-23-6-136$ & 1004.76 & 10.131 & (8) & M & $Q_{B B}$ & $F \odot P G C \Theta A F \triangle$ & foraminifer chalk & Packstone & turbidite \\
\hline $823 \mathrm{C}-24-1-7$ & 1005.67 & 10.2 & (28) & QM & & $B C F, P G B \theta \triangle A F C$ & foraminifer chalk & Packstone & turbidite \\
\hline $823 C-24-1-35$ & 1005.95 & 10.221 & a & M & $G P \& \otimes$ & $\triangle \subset B B \triangle C$ & mixed sandstone & Packstone & turbidite \\
\hline $823 \mathrm{C}-24-1-52$ & 1006.12 & 10.234 & $a c$ & G $\odot \&$ & $M B C B O$ & FrPӨ® & mixed sandstone & Grainstone & turbidite \\
\hline $823 C-24-1-82$ & 1006.42 & 10.257 & M & a & ○PBAB & GLC & nanno-foram chalk, quartzose & Wackestone & debris flow \\
\hline $823 C-24-2-28$ & 1007.38 & 10.33 & M & $\infty$ & $a_{B \otimes}$ & $L G P C C B$ & nanno-foram chalk & Packstone, Wackestone & debris flow \\
\hline $823 C-24-3-23$ & 1008.83 & 10.665 & M & $C \&$ & $P Q \otimes$ & $G \theta$ & nanno-foram chalk & Wackestone & turbidite \\
\hline $823 C-24-4-55$ & 1010.65 & 10.806 & & CQMDO & $\mathbf{P}$ & ๑ヨメの & nanno-foram chalk, quartzose & Wackestone & turbidite \\
\hline $823 C-24-4-64$ & 1010.74 & 10.806 & Q & MCD@ & G & ○ PFIB $\theta D O \triangle$ & mixed sandstone, foraminiferal & Packstone & turbidite \\
\hline
\end{tabular}



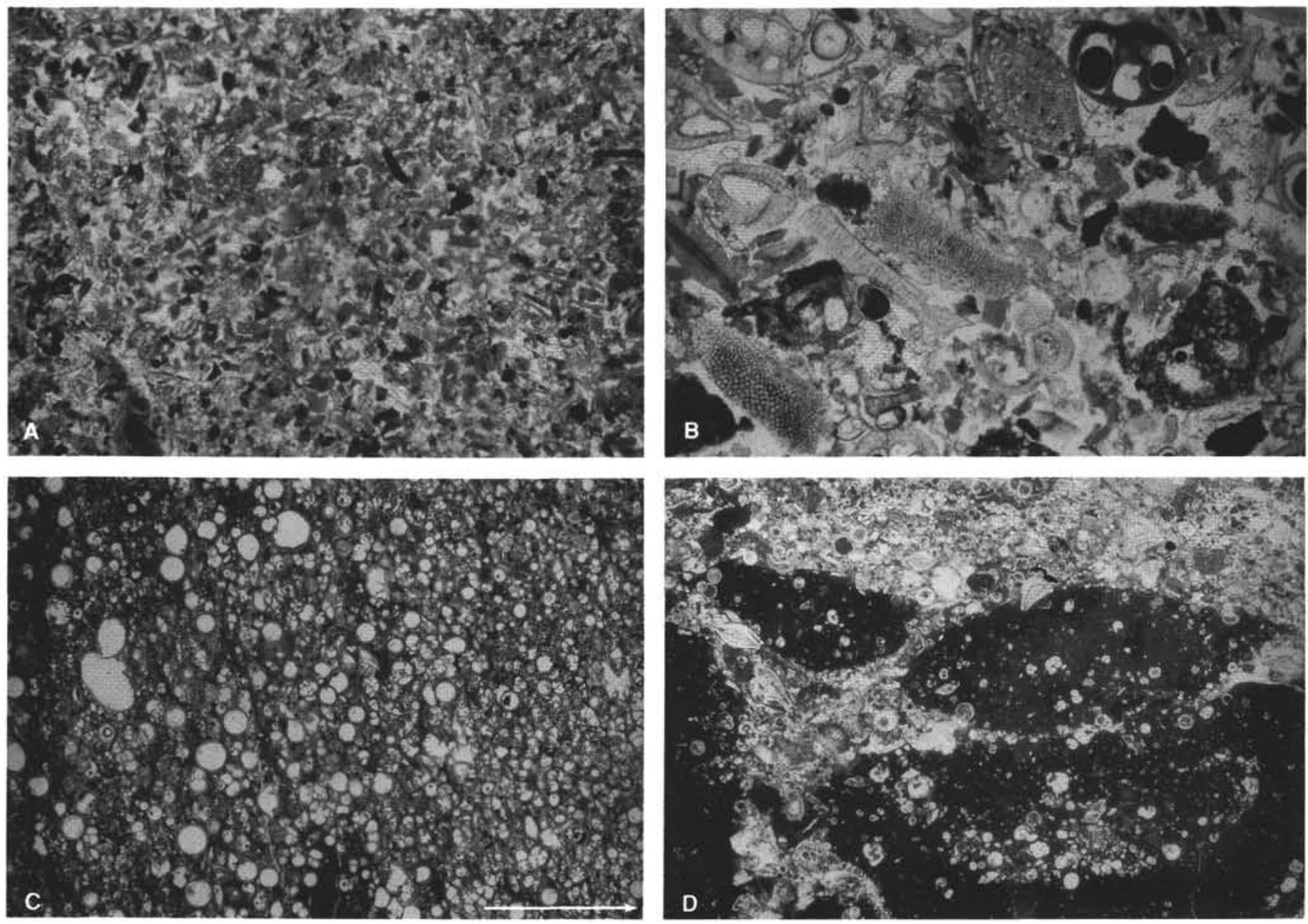

Plate 1. Photomicrographs illustrating different compositions of turbidites at Site 823. A. Bioclastic foraminiferal mixed sandstone/grainstone with quartz contains fragmented bivalves and echinoderms (Sample 133-823B-16X-3,94 cm); width of photograph $=1.33 \mathrm{~cm}$. B. Foraminiferal bioclastic grainstone contains echinoderms, bivalves, and a variety of planktonic, neritic, and agglutinated foraminifers (Sample 133-823A-5H-1, $126 \mathrm{~cm}$ ); width of photograph $=0.27 \mathrm{~cm} . \quad$ C. Graded foraminiferal chalk (top to right) is dominated by globigerinid foraminifers with lesser keeled foraminifers (Sample 133-823B-57X-1, 40 cm); width of photograph $=1.33 \mathrm{~cm}$. D. Basal part of turbidite contains rounded intraclasts of foraminiferal mixed mudstone in turbiditic foraminiferal chalk with minor bioclasts and large foraminifers. Note break-up fabric between the intraclasts (Sample 133-823C-7R-6, $56 \mathrm{~cm}$ ); width of photograph $=1.33 \mathrm{~cm}$. 

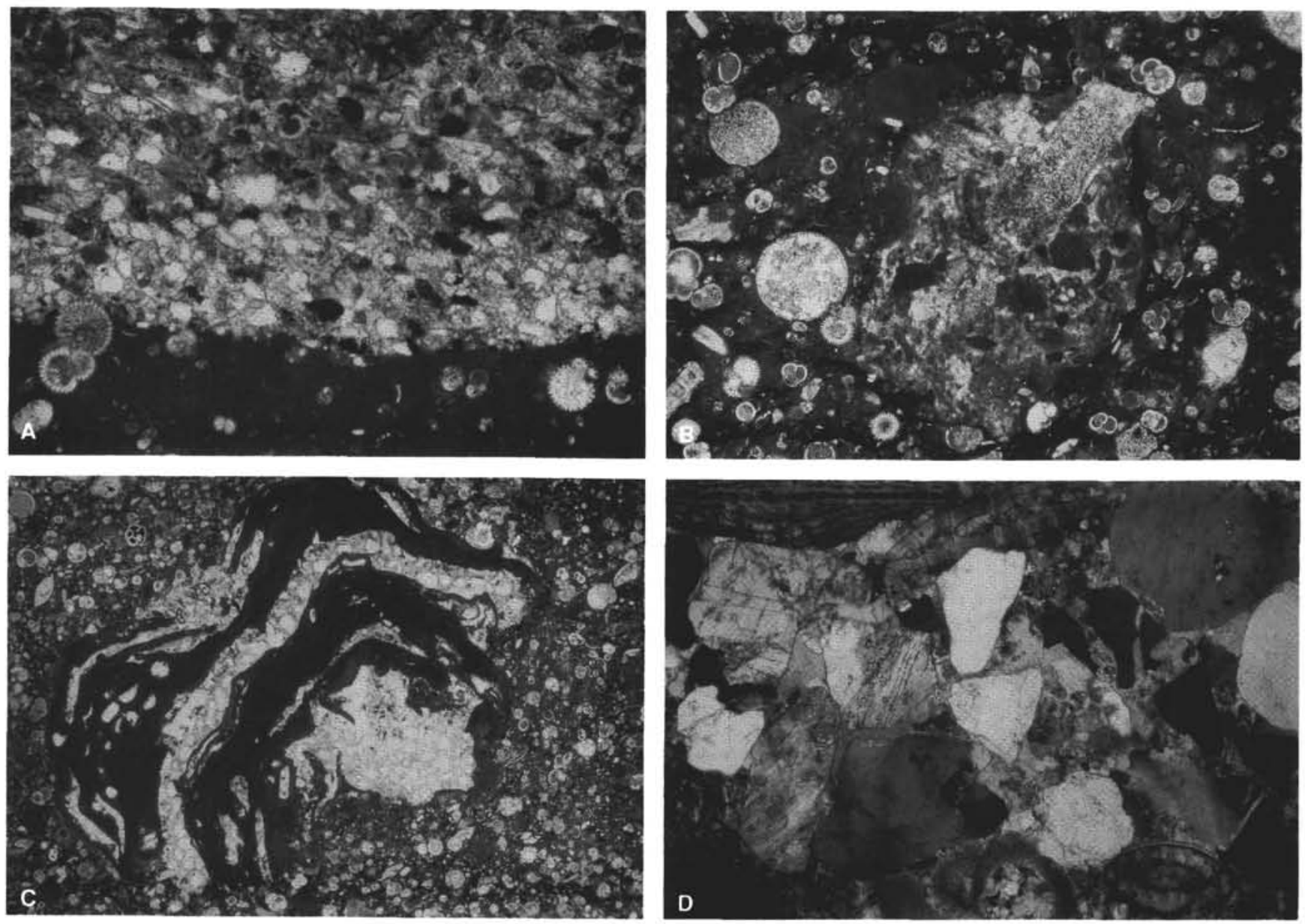

Plate 2. Photomicrographs illustrating different compositions of turbidites and debris-flow deposits at Site 823. A. Turbidite composed of foraminiferal mixed sandstone/chalk with quartz overlies a scour cut into foraminiferal mixed mudstone. Dark grains are glauconitic peloids (Sample 133-823C-11R-6, 13 cm); width of photograph $=0.27 \mathrm{~cm}$. B. Debris-flow deposit containing clast of neritic limestone in a matrix of foraminiferal nannofossil clayey calcareous chalk with bioclasts. The limestone clast is a grainstone containing red algae, echinoderms, other bioclasts, micritized grains, and neritic foraminifers (Sample 133-823C$13 \mathrm{R}-4,0 \mathrm{~cm}$ ); width of photograph $=0.48 \mathrm{~cm}$. C. Same debris-flow deposit contains a rhodolith with encrusting red algae and foraminifers suspended in a matrix of foraminiferal nannofossil clayey calcareous chalk (Sample 133-823C-13R-4, $0 \mathrm{~cm}$ ); width of photograph $=1.33 \mathrm{~cm}$. D. Very coarse-grained quartz and plagioclase in mixed sandstone also containing large foraminifers (Sample 133-823C-13R-6, $13 \mathrm{~cm}$ ); width of photograph $=0.31 \mathrm{~cm}$, crossed nicols. 

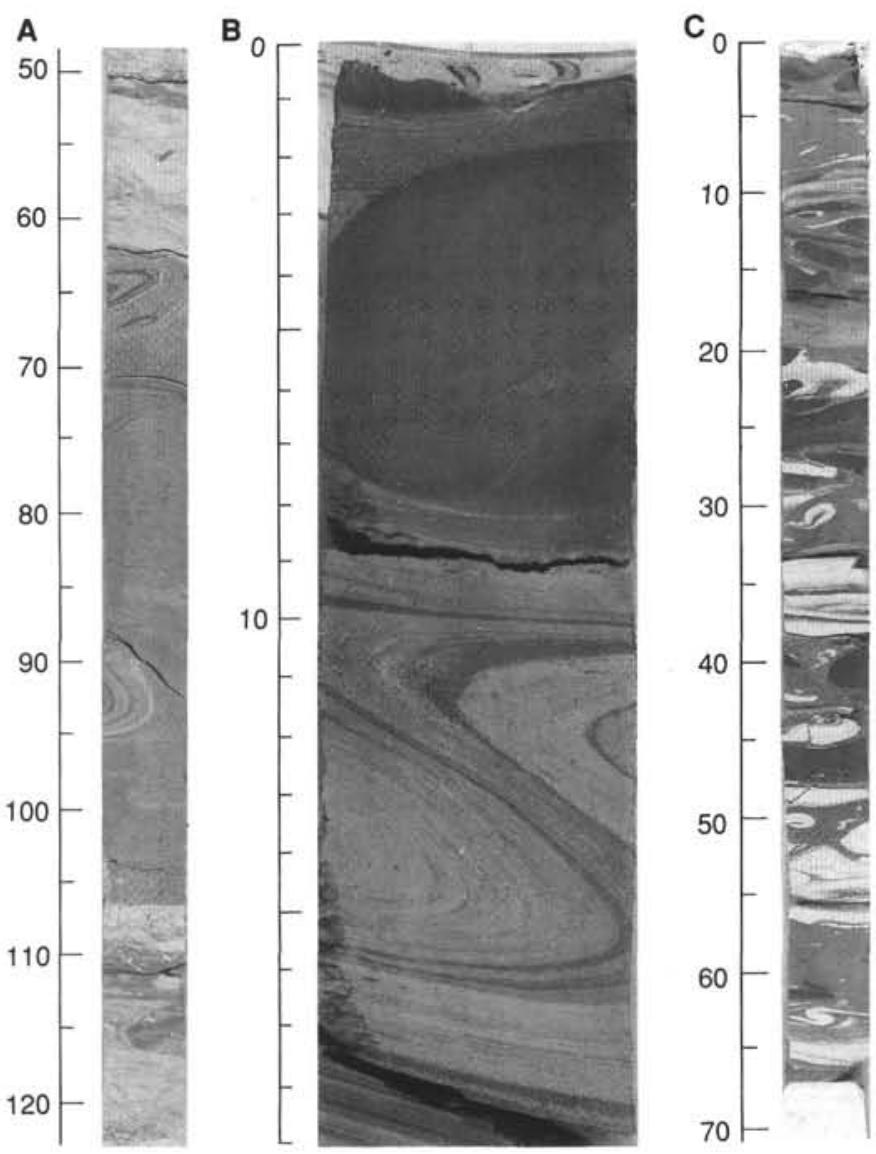

Plate 3. Core photographs illustrating the interrelationship between slump and debris-flow deposits. A. Interval of mixed mudstone having very thin interbeds of turbiditic mixed sandstone and clayey calcareous chalk intensely deformed by slump folding. Note local shearing out of some folds (interval 133-823C-1R-2, 48-123 cm). B. Closer view of recumbent fold in laminated mixed mudstone with dark turbidites interbeds. Large dark clast in the upper part of the core is composed of cohesive calcareous claystone (interval 133-823C-1R-1, 1-18 cm). C. Debris-flow conglomerate containing numerous folded clasts of chalk and rounded clasts of calcareous claystone in a matrix of mixed mudstone (interval 133-823C-7R-5, 0-67 cm). 
A

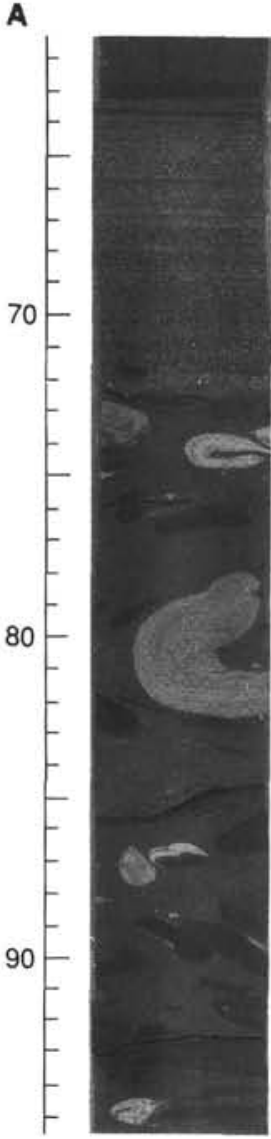

B

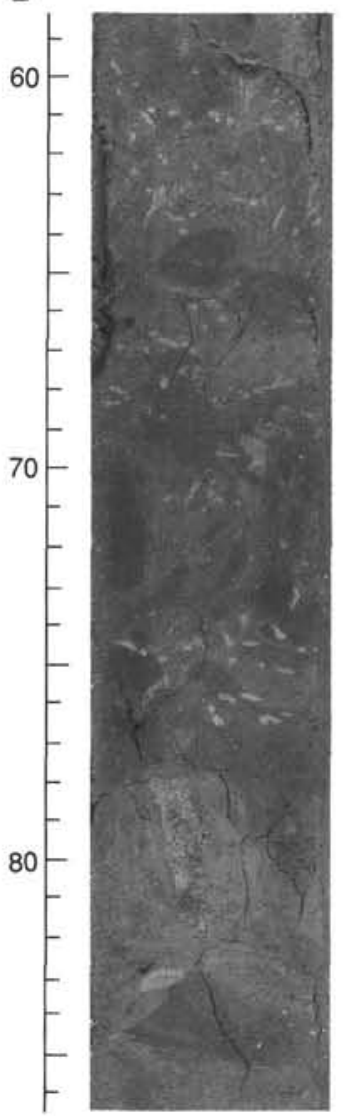

C

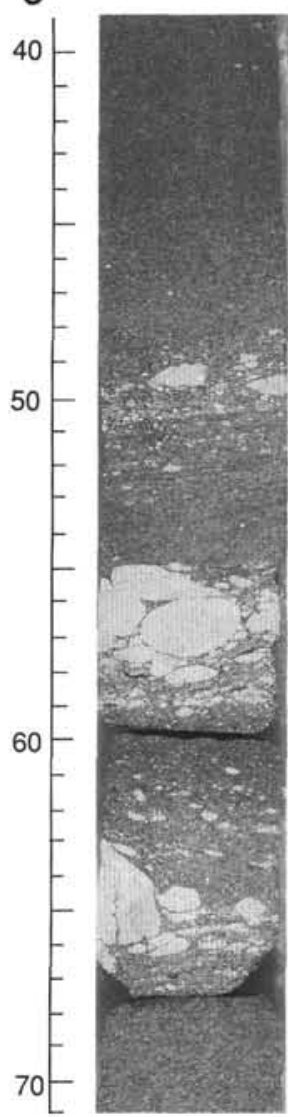

Plate 4. Core photographs illustrate the interrelationship between slump and debris flow deposits and turbidites. A. Graded and plane-laminated turbidite containing a small intraclast overlying a scour cut into the underlying debris-flow conglomerate. Note the folded clasts in the debris-flow conglomerate that also are pictured in Plate 3 (Fig. 3; interval 133-823C-7R-4, 62-96 cm). B. Intraclastic debris-flow conglomerate containing dark clasts of calcareous claystone suspended in a matrix of mixed mudstone. Note the lighter colored trace-fossils that cut across both the matrix and clasts, indicating that both were unconsolidated when deposited and that burrows cut deeply into this thick deposit (interval 133-823B-44X-4, 59-86 cm). C. Rounded intraclasts of chalk that occur at the bases of a series of amalgamated turbidites. The chalk was originally semi-consolidated calcareous pelagic ooze that eroded from the slope and became incorporated in the turbidites (interval 133-823C-7R-6, 39-71 cm). 